\title{
Miocene and Pliocene silicic Coromandel Volcanic Zone tephras from ODP Site 1124-C: Petrogenetic applications and temporal evolution
}

Matthew Thomas Stevens

A thesis submitted for the partial fulfilment for the degree of Master of Science with Honours in Geology

School of Geography, Environment and Earth Sciences

Victoria University of Wellington

November 2010 


\section{Abstract}

The Coromandel Volcanic Zone (CVZ) was the longest-lived area of volcanism in New Zealand hosting the commencement of large explosive rhyolitic and ignimbrite forming eruptions. The NW trending Coromandel Peninsula is the subaerial remnant of the Miocene-Pliocene CVZ, which is regarded as a tectonic precursor to the Taupo Volcanic Zone (TVZ), currently the most dynamic and voluminous rhyolitic volcanic centre on Earth. This study presents new single glass shard major and trace element geochemical analyses for 72 high-silica volcanic tephra layers recovered from well-dated deep-sea sediments of the SW Pacific Ocean by the Ocean Drilling Program (ODP) Leg 181. ODP Site 1124, $720 \mathrm{~km}$ south and east from the CVZ, penetrated sediments of the Rekohu Drift yielding an unprecedented record of major explosive volcanic eruptions owing to the favourable location and preservation characteristics at this site. This record extends onshore eruptive sequences of CVZ explosive volcanism that are obscured by poor exposure, alteration, and erosion and burial by younger volcanic deposits. Tephra layers recovered from Site 1124 are well-dated through a combination of biostratigraphic and palaeomagnetic methods allowing the temporal geochemical evolution of the CVZ to be reconstructed in relation to changes in the petrogenesis of $\mathrm{CVZ}$ arc magmas from $\sim 10$ to 2 Ma.

This thesis establishes major and trace element geochemical "fingerprints" for all Site 1124-C tephras using well-established (wavelength dispersive electron probe microanalysis) and new (laser ablation inductively coupled plasma mass spectrometry) in situ single glass shard microanalytical techniques. Trace element analysis of Site 1124-C glass shards (as small as $20 \mu \mathrm{m}$ ) demonstrate that trace element signatures offer a more specific, unequivocal characterisation for distinguishing (and potentially correlating) between tephras with nearly identical major element compositions. 
The Site 1124-C core contains 72 unaltered Miocene-Pliocene volcanic glass-shardbearing laminae $>1 \mathrm{~cm}$ thick that correspond to 83 or 84 geochemical eruptive units. Revised eruptive frequencies based on the number of geochemical eruptive units identified represent at least one eruption every $99 \mathrm{kyr}$ for the late Miocene and one per $74 \mathrm{kyr}$ for the Pliocene. The frequency of tephra deposition throughout the history of the CVZ has not been constant, rather reflecting pulses of major explosive eruptions resulting in closely clustered groups of tephra separated by periods of reduced activity, relative volcanic quiescence or non-tephra deposition. As more regular activity became prevalent in the Pliocene, it was accompanied by more silicic magma compositions.

Rhyolitic volcanic glass shards are characterised by predominantly calc-alkaline and minor high-K enriched major element compositions. Major element compositional variability of the tephras deposited between $10 \mathrm{Ma}$ and $2 \mathrm{Ma}$ reveals magma batches with pre-eruptive compositional gradients implying a broad control by fractional crystallisation. Trace element characterisation of glass shards reveals the role of magmatic processes that are not readily apparent in the relatively homogeneous major element compositions. Multielement diagrams show prominent negative $\mathrm{Sr}$ and $\mathrm{Ti}$ anomalies against primitive mantle likely caused by various degrees of plagioclase and titanomagnetite fractional crystallisation in shallow magma chambers. Relative $\mathrm{Nb}$ depletion, characteristic of arc volcanism, is moderate in CVZ tephras. HFSEs (e.g. Nb, Zr, Ti) and HREEs (e.g. Yb, Lu) remain immobile during slab fluid flux suggesting they are derived from the mantle wedge. LILE (e.g. Rb, Cs, Ba, Sr) and LREE (e.g. La, Ce) enrichments are consistent with slab fluid contribution. $\mathrm{B} / \mathrm{La}$ and $\mathrm{Li} / \mathrm{Y}$ ratios can be used as a proxy for the flux of subducting material to the mantle wedge, they suggest there is a strong influence from this component in the generation of CVZ arc magmas, potentially inducing melting.

CVZ tephra show long-term coherent variability in trace element geochemistry. Post $\sim 4$ Ma tephras display a more consistent, less variable, chemical fingerprint that persists up to and across the CVZ/TVZ transition at $\sim 2 \mathrm{Ma}$. Initiation of TVZ volcanism may have occurred earlier than is presently considered, or CVZ to TVZ volcanism may have occurred without significant changes in magma generation processes. 


\section{Acknowledgements}

Professor Joel Baker and Professor Lionel Carter have generously donated time in supervising this thesis, providing me with much enthusiam and encouragement for this research, and a lot of understanding throughout this difficult year. I also wish to gratefully acknowledge the professional support provided by Joel and Lionel when I accepted a fulltime position at GNS Science, thank you for all your patience as I settled in. Dr Richard Wysoczanski provided supervision prior to accepting a position at NIWA, your guidance was thoroughly appreciated.

Aidan Allan has been my honorary supervisor throughout this research. I have been very fortunate in sharing a similar research topic with Aidan; our close collaboration has saved each other much effort at times. Aidan has provided me with invaluable support, from assistance with sample sieving and mount preparation (oh joy!) to discussion and constructive feedback. One day I hope to achieve your amazing knowledge and understanding.

I would like to thank a number of fellow research students and staff at Victoria University whom have provided their time and support in various ways, I am sorry to anyone whom I have inadvertently missed. To all my fellow research students, you have been a fantastic source of dynamic discussion (many times off topic) and I thank you all for unselfishly sharing your mastery. John Patterson for your friendship and advice during work on the electron microprobe, you were a very patient instructor. Stewart Bush for your watchful eye during sample preparation. My office buddies, Aidan, Alex and Evie - I owe you all a special thank you for (mostly) keeping me on the straight and narrow except during those Friday afternoons when we shared the platform at the procrastination station. Thanks to staff at Victoria University including Euan Smith, Tim Stern and John Collen for their interest, discussion and advice.

The text of this thesis has benefited from editorial critisim by my supervisors, but I would like to thank Michael Gazley, Katie Collins and Sarah Grain for their 'speedy' editing during final stages of this thesis, especially during final proofreading. Michael and Sarah, thank you for the much-needed coffee breaks, I think we now own several of the cafes on campus. The companionship of my friends has carried me through the highs and lows of this project.

I would like to acknowledge the staff at Geosphere Ltd, thank you for taking an interest in this research. To the GeoNet team, I extend my thanks to those whom have endured my endless discussions about my research (it will now stop), and seen me on the days where I forgot to sleep the night before (no more grumpy Matt). Kevin, I thank you for your quiet understanding and fantastic support, thank you for taking me on even though I carried some baggage.

To my family, for their continued encouragement and support during my studies. Lesley, thank you for the last minute formatting assistance and cheering me to the finish line.

Michaela, your constant love, encourgement and inspiration have carried me through this research. You provided me with the strength to reach this goal, and have stood by me completely during the highs and many lows. I dedicate this thesis to you. 


\section{Table of Contents}

ABSTRACT 2

ACKNOWLEDGEMENTS $\quad 4$

TABLE OF CONTENTS

LIST OF FIGURES $\quad 8$

\begin{tabular}{ll} 
LIST OF TABLES & 11 \\
\hline
\end{tabular}

1.0 INTRODUCTION

1.1 Regional TeCtonic Setting 12

1.2 Coromandel Volcanic Zone 13

1.2.1 ONSHORE MIOCENE-Pliocene VOLCANIC RECORD OF SILICIC VOLCANISM 14

1.3 OFFSHORE VolCANIC RECORD - OCEAN DRILLING PROGRAM Site 1124

1.3.1 RECOGNITION OF TEPHRA LAYERS AT OCEAN DRILLING PROGRAM SITE 1124-C 16

$\begin{array}{ll}\text { 1.3.2 AGE MOdELS } & 17\end{array}$

$\begin{array}{lll}\text { 1.3.3 } & \text { FREQUENCY OF ERUPTIONS } & 19\end{array}$

1.4 TEPHROSTRATIGRAPHY/TEPHROCHRONOLOGY 22

1.4.1 NOMENCLATURE 22

1.4.2 REVIEW OF VOLCANIC ASH GENERATION, TRANSPORTATION AND DEPOSITION 23

1.4.3 TEPHRA FALl DEPOSITS 25

1.5 GEOCHEMICAL EVALUATION OF ODP Site 1124-C TEPHRA LAYERS 26

1.5.1 ElECtron Probe Microanalysis (EPMA) 27

1.5.2 LASER ABLATION INDUCTIVELy COUPLED PlASMA MASS SPECTROMETRY (LA-ICP-MS)

1.6 OBJECTIVES OF THIS THESIS

1.7 TheSis STRUCTURE $\quad 30$ 
2.1 SAMPLE ACQUISITION 32

2.2 SAMPLE PREPARATION 32

2.3 ElECtron Probe MicroanAlysis (EPMA)

2.3.1 PRECISION AND ACCURACY OF MAJOR ELEMENT DATA 36

2.3.2 Existing Major Element Data For Miocene-Pliocene Coromandel VolCANiC $\begin{array}{ll}\text { ZONE TEPHRAS } & 37\end{array}$

2.4 LaSer Ablation Inductively COUPLED Plasma MaSs SPECTROMETRY (LA-ICPMS) $\quad 39$

2.4.1 LA-ICP-MS DATA ACQUISITION AND CALCULATION 41

2.4.2 PRECISION AND ACCURACY OF TRACE ELEMENT DATA 42

2.4.2.1 The Use of Different Internal Standards 45

2.4.3 EXISTING Trace ElEMENT DATA For Miocene-Pliocene COROMANDEL VOlCANIC ZONE TEPHRAS

3.0 RESULTS - COMPOSITION OF THE SILICIC TEPHRAS

3.1 MAJOR ELEMENT GEOCHEMISTRY

3.1.1 ClassifiCATION OF SITE 1124 TEPHRA LAYERS 51

3.1.2 TEMPORAL CHANGES AND GLASS COMPOSITION 53

3.2 Trace Element GeOChemistry $\quad 58$

3.2.1 High FIELD STRENGTH ElEMENTS (HFSE) AND RARE EARTH ELEMENTS (REE) 59

3.2.2 RARE EARTH ELEMENT DIAGRAMS

3.2.3 NORMALISED MULTI-ELEMENT DiagRAMS

3.2.4 TEMPORAL CHANGES IN CHEMISTRY AND GLASS COMPOSITION 63

3.2.5 LITHIUM AND BORON GEOCHEMISTRY 68

4.0 DISCUSSION

$\begin{array}{lll}4.1 & \text { INTRA-TEPHRA VARIATION } & \mathbf{7 4}\end{array}$

4.1.1 BIMODALITY 74

4.1.2 CRYSTAL FRACTIONATION

4.1.3 DIFFUSIVE VARIABILITY, HOMOGENEITY AND MAGMA MIXING 77

4.1.4 POTENTIAL ANALYTICAL ARTEFACTS IN SECONDARY DATA NORMALISATION 80

4.2 TEMPORAL EVOLUTION AND THE CVZ-TVZ TRANSITION 81

4.2.1 TEMPO OF EXPLOSIVE SILICIC ERUPTIONS FROM THE CVZ 81 
4.2.2 IMPLICATIONS FOR PlATE TECTONIC RECONSTRUCTIONS

4.2.3 CVZ-TVZ TRANSITION

4.3 Petrogenesis of CVZ Magmas 87

4.4 ASSESSING THE SLAB-TO-MANTLE TRANSFER OF LITHIUM AND BORON 91

5.1 ProjeCt AChIEVEMENTS AND CONCLUSIONS

5.2 FUTURE WORK 


\section{List of Figures}

Figure 1.1 Location map showing the New Zealand oceanic setting, the location of the CVZ relative to the TVZ and location of Site 1124-C and other ODP Leg 181 drill core sites. Also depicted are plate reconstructions of New Zealand at $10 \mathrm{Ma}$ and $2 \mathrm{Ma}$.

Figure 1.2 Photo of a representative tephra-bearing sediment core from ODP Site 1124-C.

Figure 1.3 Wet bulk density plot for ODP Site 1124-C, 68.24-207.10 mbsf.

Figure 1.4 Summary of the ODP Site 1124-C composite stratigraphy.

Figure 1.5 Summary of the routes pyroclastic ejecta can follow after eruption.

Figure 2.1 Glass shards mounted in a 'half-moon' epoxy resin mount with (A) and without (B) carbon coating.

Figure 2.2 Back-scattered electron image of volcanic glass shards from a representative Site 1124-C tephra layer.

Figure 2.3 Measured trace element composition of ATHO-G using both (A)

${ }^{29} \mathrm{Si}$ and (B) ${ }^{43} \mathrm{Ca}$ internal standards, normalised to reference values.

Figure 3.1 Total alkalis versus silica (TAS) plot (mean concentrations) for Site 1124-C tephras.

Figure 3.2 Bivariate plot of $\mathrm{K}_{2} \mathrm{O}$ and $\mathrm{SiO}_{2}$ data (mean concentrations) for Site 1124-C tephras.

Figure 3.3 Temporal geochemical evolution plots of selected major element data (mean concentrations) for Site 1124-C tephras.

Figure 3.4 Bivariate plots of selected major element data (mean concentrations) for Site 1124-C tephras. 
Figure 3.5 Bivariate plot of $\mathrm{Na}_{2} \mathrm{O}$ and $\mathrm{SiO}_{2}$ data (individual shard concentrations) for Site 1124-C tephras.

Figure 3.6 Bivariate trace element ratio plot (mean concentrations) demonstrating the relationship between HFSEs and REEs for Site 1124-C tephras.

Figure 3.7 Chondrite-normalised REE diagram (mean concentrations) for 60 Site 1124-C tephras.

Figure 3.8 Multi-element spider diagram normalised to primitive mantle values (mean concentrations) for Site 1124-C tephras.

Figure 3.9 Temporal geochemical evolution plots of selected trace element ratios (mean concentrations) for Site 1124-C tephras.

Figure 3.10 Bivariate trace element and trace element ratios plots (mean concentrations) for Site 1124-C tephras.

Figure 3.11 Temporal geochemical evolution plots of Li and B (mean concentrations) for Site 1124-C tephras.

Figure 3.12 Bivariate trace element and trace element ratios plots (mean concentrations) demonstrating the behaviour of Li and B for Site 1124-C tephras.

Figure 3.13 Bivariate trace element ratio plot (mean concentrations) demonstrating the relationship between B/La and REEs for Site 1124-C tephras.

Figure 4.1 Bivariate major and trace element and trace element ratios plots (individual shard concentrations) demonstrating the chemical bimodality for representative Site 1124-C tephras.

Figure 4.2 Bivariate trace element plots (individual shard concentrations) demonstrating the chemical heterogeneity from fractional crystallisation for representative Site 1124-C tephras. 
Figure 4.3 Bivariate trace element and trace element ratios plots (individual shard concentrations) demonstrating diffusive variability, homogeneity and mixing trends for representative Site 1124-C tephras.

Figure 4.4 Bivariate plot of $\mathrm{FeO}$ and $\mathrm{K}_{2} \mathrm{O}$ data (individual shard concentrations) for high-K Site 1124-C tephras. Inset: Bivariate plot of $\mathrm{Rb}$ and $\mathrm{K}_{2} \mathrm{O}$ data (individual shard concentrations) for high-K Site 1124-C tephras.

Figure 4.5 Bivariate trace element ratio plot (mean concentrations) demonstrating the relationship between HFSEs and B/La for Site 1124-C tephras. 


\section{List of Tables}

Table 2.1 EPMA instrumental and analytical operating parameters.

Table 2.2 EPMA precision and accuracy for international basaltic glass standard VG-A99 measured in this study.

Table 2.3 Instrumental and analytical operating parameters during EPMA 38 of previous studies.

Table 2.4 LA-ICP-MS instrumental and analytical operating parameters.

Table 2.5 LA-ICP-MS precision and accuracy for international rhyolitic glass standard ATHO-G measured in this study.

Table 2.6 LA-ICP-MS precision and accuracy for international rhyolitic glass standard ATHO-G measured in this study, using both ${ }^{29} \mathrm{Si}$ and ${ }^{43} \mathrm{Ca}$ as the internal standard isotope. 


\subsection{Introduction}

\subsection{Regional Tectonic Setting}

The continental crust of New Zealand has occupied a position on the convergent Pacific and Australian plate boundaries throughout the late Cenozoic (Figure 1.1). In the north, dense oceanic crust of the Pacific Plate is obliquely subducted under the buoyant continental crust of the Australian Plate, whereas in the south, the oceanic crust of the Australian Plate is obliquely subducted under the continental crust of the Pacific Plate. The two subduction systems are linked by the oblique strike-slip movement associated with continent-continent collision between these two tectonic plates. The late Cenozoic tectonic history of New Zealand is complex and several plate tectonic reconstruction models have been proposed (e.g. King, 2000), in some cases, with emphasis on the association of volcanism and tectonism in the North Island (e.g. Kear, 1994; 2004). The tectonic setting of late Cenozoic arc volcanism in New Zealand has been directly related to collision and extension, with the migration of arc volcanism southwards with time, a response to the progressive changes in the location, orientation and dip of the subducted Pacific Plate (Cole, 1986; King, 2000).

In New Zealand, there have been numerous studies focusing on Quaternary arc volcanism, associated with the Taupo Volcanic Zone (TVZ), which is the most frequently erupting and highly productive rhyolitic centre in the world (e.g. Houghton et al., 1995; Wilson et al., 1995). 


\subsection{Coromandel Volcanic Zone}

The NNW-trending Coromandel Volcanic Zone (CVZ) is a basement horst structure hosting arc volcanism related to the WNW-dipping Pacific Plate beneath the Australian Plate (Skinner, 1986). The CVZ was the dominant region of volcanism from $18 \mathrm{Ma}$ to 2 Ma in New Zealand (Adams et al., 1994; Carter et al., 2004). Subsequent changes in the pole of rotation of the Pacific Plate resulted in the realignment of the volcanic zones to the NNE and the currently active $\sim 2$ Ma rifted continental arc of the TVZ. The CVZ is regarded as the tectonic precursor to the TVZ (Skinner, 1986; Adams et al., 1994; Carter et al., 2003; 2004; Briggs et al., 2005) (Figure 1.1).

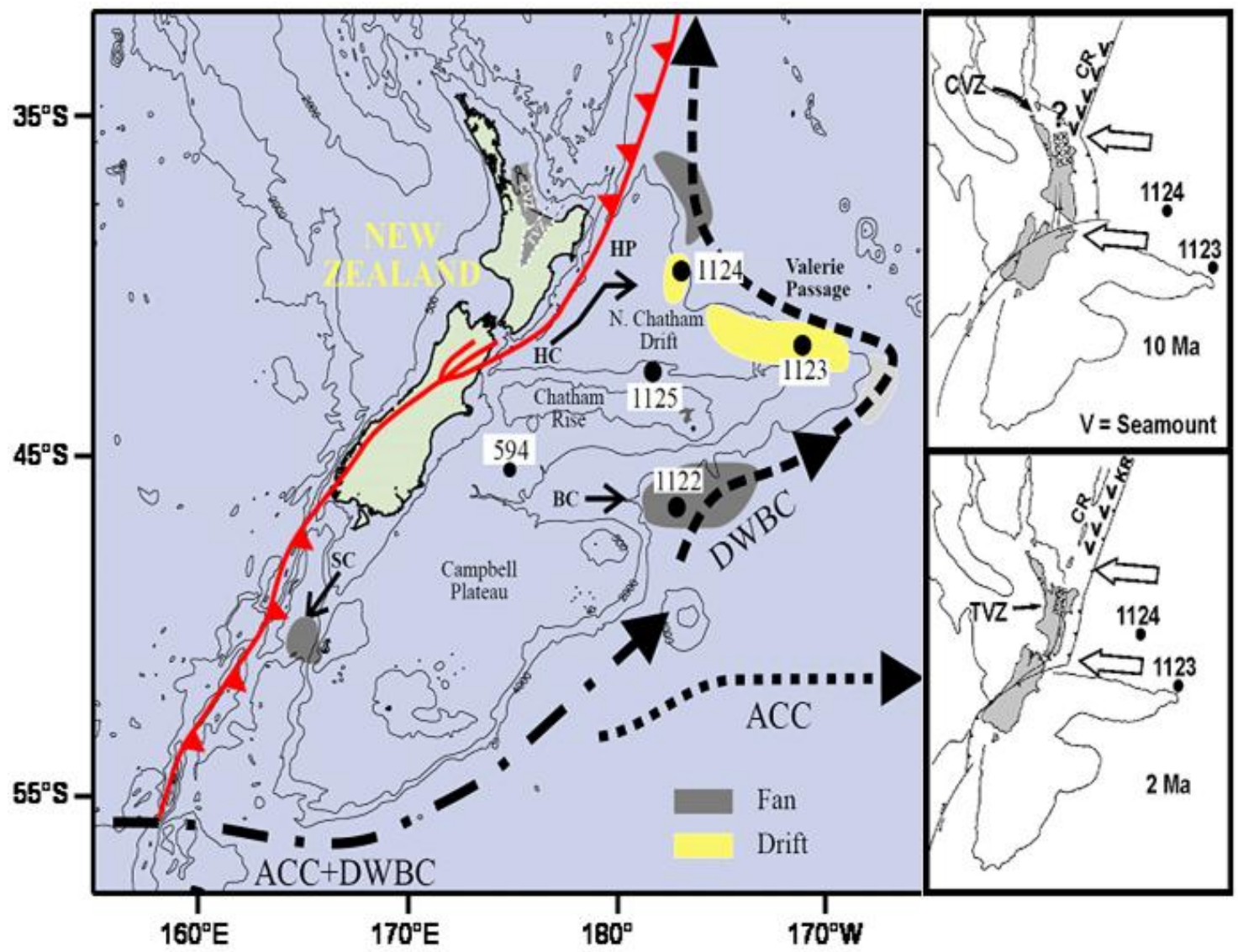

Fig. 1.1: Present day configuration of the main North Island volcanic centres mentioned in the text, Coromandel Volcanic Zone (CVZ) which propagated southeast to be replaced by the Taupo Volcanic Zone (TVZ). Locations of Ocean Drilling Program (ODP) Leg 181 core sites 1122, 1123, 1124 and 1125 are shown, as well as the location of Deep Sea Drilling Program (DSDP)-594. Also depicted is the Australian-Pacific Plate boundary; bathymetric features (HP, Hikurangi Plateau); areas of sediment accumulation (fans and drifts); deep ocean currents (ACC, Antarctic Circumpolar Current; DWBZ, Deep Western Boundary Current) and submarine channel systems (SC, Solander Channel; BC, Bounty Channel; HC Hikurangi Channel) (modified from Weedon and Hall, 2004). Plate reconstructions (from Carter et al., 2004; King, 2000) outline the development of the Pacific/Australian plate boundaries at $10 \mathrm{Ma}$ and $2 \mathrm{Ma}$. ODP Leg 181 sites 1123 and 1124 are marked to illustrate the movement of the depocentres relative to the evolving volcanic zones. 
Onshore geochronological studies indicate initiation of CVZ volcanism was marked by the onset of andesitic magmatism at $\sim 18 \mathrm{Ma}$ (Adams et al., 1994). Volcanism migrated southeastwards with time. At $\sim 10 \mathrm{Ma}$ the CVZ became dominated by rhyolitic volcanism that continued more or less non-stop until $2 \mathrm{Ma}$ (Skinner, 1986).

Explosive volcanism resulted in the deposition of widespread fall deposits of volcanic ash or tephra across the North Island and offshore environments (Carter et al., 2003; 2004). Silicic volcanic centres have been identified using criteria such as negative gravity anomalies (Malengreau et al., 2000; Smith et al., 2006), circular or arcuate structures and the spatial association of thick intracaldera ignimbrites and silicic dome complexes (Briggs and Fulton, 1990). Large ignimbrite deposits of the onshore region hold the most significance for this study because they indicate the likelihood of widespread airfall ash (Baker and Francis, 1978).

The transition from CVZ to TVZ is considered to have occurred without a major hiatus in activity, and obvious change in major element geochemistry, suggesting either a continuation or overlapping interval when both the CVZ and TVZ were active (Carter et al., 2004). Rocks from the Tauranga area and Kaimai Range represent an important geographical and chronological transition from Miocene-Pliocene aged eruptives of the CVZ to the Pleistocene-Recent TVZ (Briggs et al., 2005). ${ }^{40} \mathrm{Ar} /{ }^{39} \mathrm{Ar}$ age determinations on these exposed volcanic rocks date the transition as being between 1.90 and $1.60 \mathrm{Ma}$ (Briggs et al., 2005).

\subsubsection{Onshore Miocene-Pliocene Volcanic Record of Silicic Volcanism}

The chronology of late Cenozoic volcanism from the CVZ recorded in terrestrial deposits can be difficult to ascertain for the following reasons:

1) Normal stratigraphic relationships are disrupted by deformation and/or intrusion by younger eruptives.

2) Hydrothermal alteration compromises the geochemical characterisation of volcanic deposits, particularly in areas more proximal to the CVZ, which means age constraints are spurious.

3) Poor exposures due to burial of eruptive centres by infilling of younger sediment or submergence by seawater. 
4) Erosion of weakly consolidated volcanic ejecta, which may result in minimal or no preservation.

5) Destruction of volcanic centres by younger volcanic activity.

Addressing this knowledge gap is one of the foremost objectives of the present study.

\subsection{Offshore Volcanic Record - Ocean Drilling Program Site 1124}

The reliable reconstruction of the temporal evolution of the CVZ requires a coherent, highly resolved rock record, which for reasons outlined in the previous section cannot be obtained from onshore exposures. However, it can be obtained from the distal fallout of tephra generated from explosive arc volcanism preserved within marine sediments from the SW Pacific Ocean. In 1998, ODP Leg 181 recovered a suite of cores off eastern New Zealand (Carter et al., 2003; 2004). Located eastward of the North Island, ODP Site 1124 $\left(39^{\circ} 29.90^{\prime} \mathrm{S}, 176^{\circ} 31.89^{\prime} \mathrm{W} ; 3966 \mathrm{~m}\right.$ water depth) is situated approximately $720 \mathrm{~km}$ from the extinct CVZ (Figure 1.1). Site 1124 was positioned downwind of the main volcanic ash dispersal path and by virtue of its distance from the CVZ, collected a record of airfall deposits from mainly explosive rhyolitic eruptions.

Coring at ODP Site 1124 penetrated the sediments of the Rekohu sediment drift that were deposited under the waning flow of the Pacific Deep Western Boundary Current (DWBC) after passing through the Valerie Passage (Carter and McCave, 1994) (Figure 1.1). The DWBC did not exert a major influence on sedimentation at ODP Site 1124 from 9 Ma to present (Joseph et al., 2004). Four cores were drilled at ODP Site 1124: A, B, C, and D. The A core failed, the B core resulted in a shattered barrel liner and the D core had multiple sediment gaps and cored back as far as the late Miocene. The $\mathrm{C}$ core yielded a near-continuous record of sedimentation from the late Cretaceous to the Recent, and represents the most complete sequence of late Miocene to Recent marine tephras yet obtained for New Zealand.

Preserved within the sediments of the Site 1124-C core are 134 tephra layers which document $\sim 12 \mathrm{Myr}$ of almost entirely silicic volcanism from the extinct CVZ and the currently active TVZ (Carter et al., 2003; 2004). In the late Miocene to Pliocene section of the Site 1124-C record, the focus of this thesis, 76 macroscopic tephra layers were recovered (Appendix One). 


\subsubsection{Recognition of Tephra Layers at Ocean Drilling Program Site 1124-C}

Tephra fall layers are important components of some deep-sea sediments adjacent to areas of explosive volcanism (Kennett, 1981). ODP Site 1124-C recovered macroscopic tephras within Subunit 1B and upper Subunit 1C (Shipboard Scientific Party, 1999) consisting of thick beds of silty clay grading to nannofossil silty clay, intercalated with clayey nannofossil ooze grading to nannofossil ooze (with ooze changing to chalk in Subunit 1C) (Figure 1.2). A typical tephra layer exhibits a sharp base, normal grading and a diffuse/bioturbated top with the overlying sediment (Figure 1.2). Turbidity processes can be discounted for origin of emplacement of these layers due to coring site location on bathymetric highs above turbidity flow paths. Evidence of soft sediment deformation is apparent where the sharp tephra base is deformed due to coring (e.g. $1124 \mathrm{C} 9 \mathrm{H} 4,78 \mathrm{~cm}$, 89.48 metres below sea floor (mbsf), Figure 1.2). Members of the onboard shipping party were responsible for the initial visual inspection and description of split cores, as well as logging and recording of the physical properties of all macroscopic tephra layers that were identified (Shipboard Scientific Party, 1999). The term 'macroscopic tephra layers' encompasses all laminae and beds of tephra > $1 \mathrm{~cm}$ thick (Carter et al., 2003; 2004). Specific logging tools used included light reflectance, magnetic susceptibility, natural gamma ray and bulk density (Carter et al., 2004). 


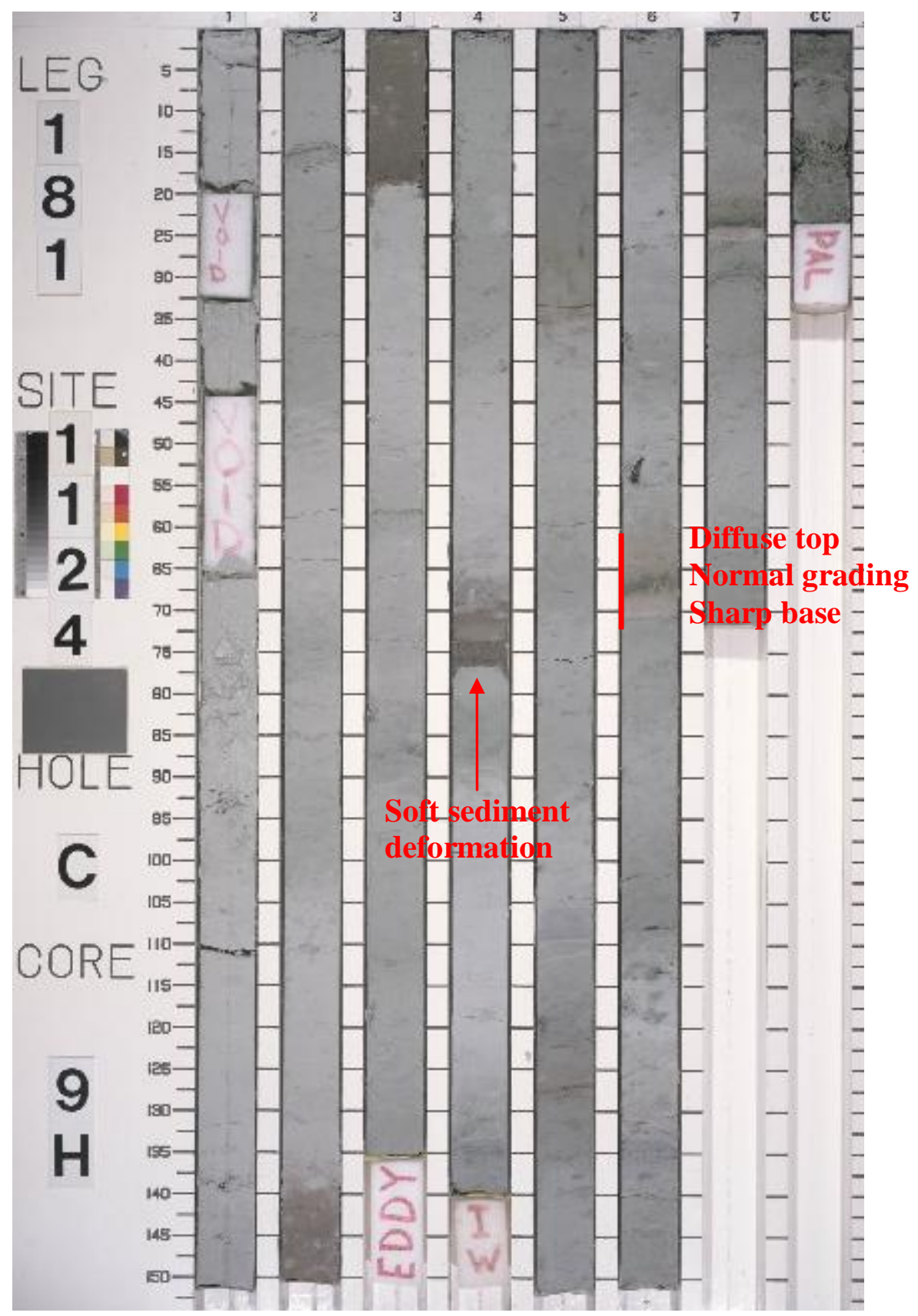

Fig. 1.2: Pinkish grey to light pinkish grey tephra layers with enclosing light grey carbonate sediments (1124 C9H1-7). Tephra layer at position C9H4 $78 \mathrm{~cm}$ displays soft sediment deformation; tephra layer at position C9H6 $71 \mathrm{~cm}$ displays typical depositional characteristics of tephra. Photo taken by Shipboard Scientific Party (available at: http://iodp.tamu.edu/janusweb/imaging/photo.shtml).

\subsubsection{Age Models}

Marine airfall tephra are, for the most part, in correct stratigraphic order (unless they have been deformed by post-depositional gravitational instability such as slumping (e.g. Allan et al., 2008)), allowing tephras to be readily dated by magnetostratigraphic or biostratigraphic methods used during the course of Leg 181 (Shipboard Scientific Party, 1999). The micropalaeontological biostratigraphy of Site 1124 is mostly based on the onboard study of 
core-catcher samples (Shipboard Scientific Party, 1999). Nannofossils proved the most useful for dating throughout the hole and despite the poor preservation of microfossils in the Oligocene and Neogene strata, foraminifera provided good age resolution in the uppermost Miocene to Pliocene, and in the Cretaceous and Paleogene (Shipboard Scientific Party, 1999).

First-order age control on 72 of the 76 Miocene-Pliocene tephra layers was achieved by the identification of key palaeomagnetic boundaries. Onboard, core halves were passed through a cryogenic magnetometer and measured for declination, inclination and intensity of natural remnant magnetisation (Shipboard Scientific Party, 1999). Interpretation of magnetic polarity is well constrained by key foraminiferal and nannofossil data for each of the core-catcher samples (Shipboard Scientific Party, 1999). Each tephra layer has been assigned a palaeomagnetic age estimate after the Global Polarity Time Scale (GPTS) of Cande and Kent (1995) and Berggren et al. (1995). The Site 1124-C palaeomagnetic record is continuous to $11 \mathrm{Ma}$, but only reliable to $27 \mathrm{Ma}$ (Carter et al., 2004). A strong magnetic overprint is reported to have been encountered between 180 and $280 \mathrm{mbsf}$, preventing unambiguous polarity determination over that interval (Shipboard Scientific Party, 1999).

Noted in the core logs of ODP Site 1124-C were scattered laminae of green silty clay, representing the presence of authigenic smectite (Nelson et al., 1986; Shipboard Scientific Party, 1999). In the Site 1124-C core, these green laminae are restricted to the oldest four tephra layers (e.g. M-73 to M-76). These four laminae underwent identical preparation and analytical procedures as all other tephra samples in this study. Samples M-73 to M-76 were found to contain rare or no shards of volcanic glass (M-76 yielded 2 glass shards). Figure 1.3 illustrates how the wet bulk-density of late Miocene-to Pliocene-aged sediments from Site 1124-C changes with increasing depth below sea floor. At 178 mbsf wet bulk density begins to constantly increase, which may signify chemical diagenesis of the sediment. Furthermore, potential alteration of the sediment below $\sim 178 \mathrm{mbsf}$ could account for the strong magnetic overprint encountered after 180 mbsf. Poor preservation of age datum and strong dissolution of foraminifera over this interval may coincide with chemical alteration (Shipboard Scientific Party, 1999). However, research conducted by Nelson et al. (1986) provides evidence and reasoning to suggest that these laminae from Site 1124-C can be considered altered layers of volcanic ash. These laminae (M-73 to M76) have been excluded from this study $(n=72)$ restricting the length of the core that can 
be used for tephrochronologic studies (Figure 1.4). The maximum sample depth of tephra analysed in this study is $177.80 \mathrm{mbsf}$ (age $=9.28 \mathrm{Myr}$ ).

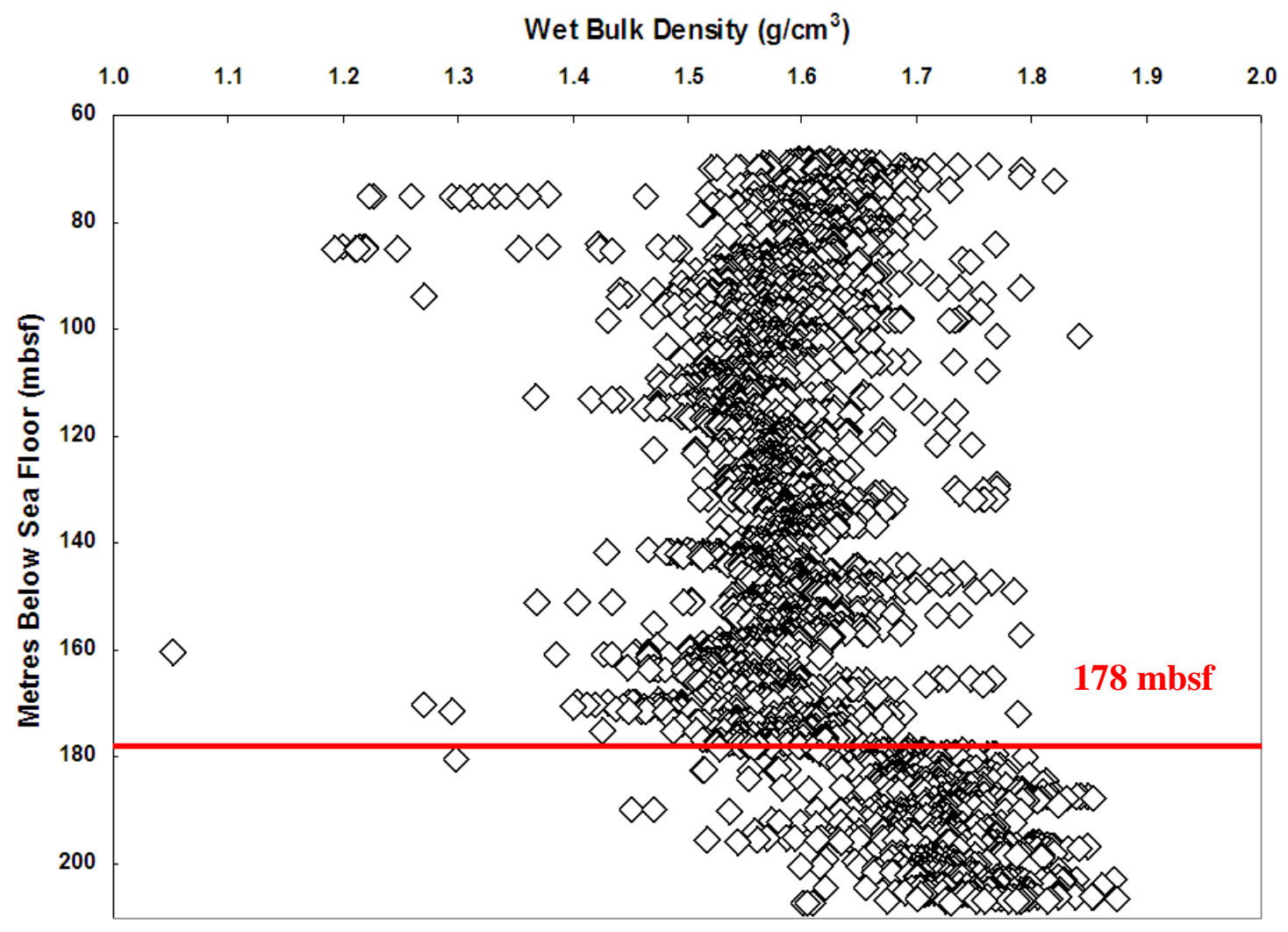

Fig. 1.3: Wet bulk density plot for ODP Site 1124-C, $68.24-207.10$ mbsf. Bulk density is constantly high down core from $\sim 178$ mbsf. Data available at:

http://iodp.tamu.edu/janusweb/physprops/gradat.shtml.

\subsubsection{Frequency of Eruptions}

The temporal distribution of tephra throughout the late Miocene and Pliocene reflects pulses of major explosive eruptions punctuated by periods of reduced activity, relative volcanic quiescence or non-tephra deposition (Figure 1.4). Ledbetter and Sparks (1979) used the absence of bioturbation in tephra layers in the deep sea to suggest that there was a rate of ash accumulation that smothered the bioturbating fauna. However, these authors do not state the threshold of ash smothering. In this research it is considered to be $1 \mathrm{~cm}$ of ash, which is corroborated by Kennett (1981), who notes that thinner layers are rarely preserved and are presumably removed as a consequence of bioturbation and/or bottom current reworking. The use of tephra fall deposits to reconstruct the evolution of the CVZ will result in a tephrostratigraphic record biased in favour of the more explosive silicic eruptions. 
The Miocene tephra record in Site 1124-C is marked by nine clusters of tephra at $9.3-9.2$ Ma, 8.6 - 8.4 Ma, 7.8 - 7.6 Ma, 7.3 - 6.9 Ma, 6.3 - 5.9 Ma, 5.5 - 4.5 Ma crossing the Miocene - Pliocene boundary, followed by 4.1 - 3.7 Ma, 3.5 - 2.9 Ma and 2.4-2.1 Ma in the Pliocene (Figure 1.4) (cf. Carter et al., 2003; 2004). Periods of reduced volcanism or non-tephra deposition are < $0.5 \mathrm{Myr}$ for the Pliocene, but up to $0.8 \mathrm{Myr}$ for the late Miocene. Eruptive frequencies can be inferred, based on the number of preserved eruptive units per time interval, to be one per $120 \mathrm{kyr}$ for the late Miocene and one per $82 \mathrm{kyr}$ for the Pliocene ( $n=33$ and 39, respectively). These values represent minimum eruptive frequencies based on the number of visible tephra layers, and as geochemical investigation of the tephra layers appears to reveal bimodal chemistries in several of the samples. Based on the Pleistocene section of the Site 1124-C stratigraphy, Carter et al. (2003) calculated an eruptive frequency of one per $35 \mathrm{kyr}$, suggesting that more frequent deposition continued into the Quaternary when periods of reduced volcanism or non-deposition of macroscopic tephras were < 0.2 Myr (Carter et al., 2004). 


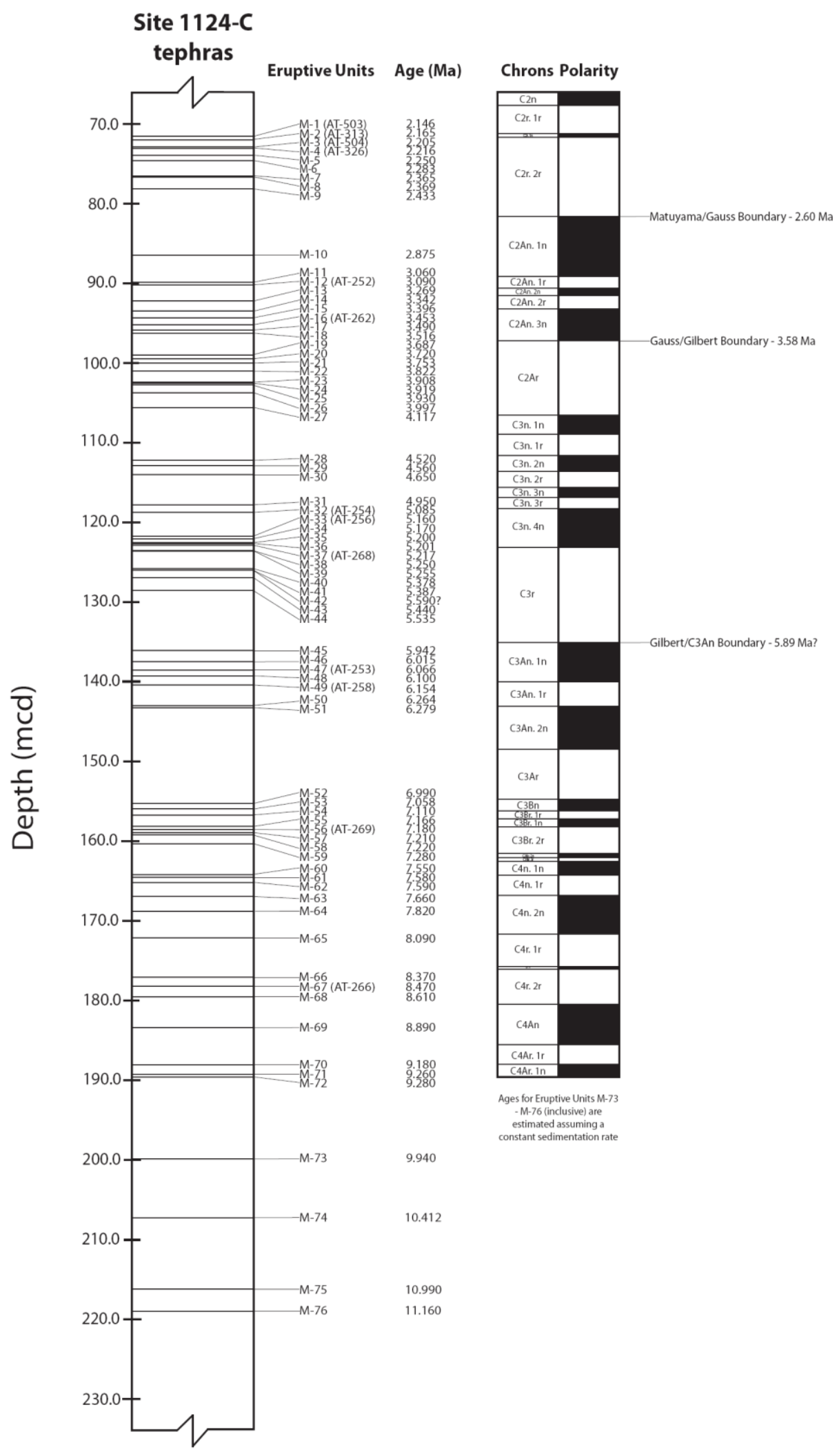

Fig. 1.4: Summary of the ODP Site 1124-C composite stratigraphy that contains late Miocene to Pliocene CVZ derived tephras $(2.15-11.16 \mathrm{Ma})$. $\mathrm{mcd}=$ metres composite depth. Note the four oldest tephra layers (M-73 - M-76 inclusive) are altered. Thirteen tephra samples analysed in this study have been allocated the sample numbers used previously by Carter et al. (2004), in conjunction with the sample numbers assigned in this study (Appendix One). 


\subsection{Tephrostratigraphy/Tephrochronology}

Cenozoic silicic tephras have been studied widely in the central North Island, New Zealand for over 100 years (e.g. Cusson, 1888; Aston, 1926; 1927). Understanding their stratigraphy, distribution, and eruptive nature has gradually built upon a comprehensive tephrostratigraphic framework. Our present day knowledge of tephra can be attributed to the influential work of many researchers (e.g. Healy, 1964; Vucetich and Pullar, 1964; Walker, 1979; 1980; Froggatt, 1983; Froggatt and Lowe, 1990; Lowe, 1990; Wilson et al., 1995; Shane, 2000). In order to reconstruct a reliable chronology and more complete history for older volcanic eruptions (hindered by the fragmentary terrestrial record) the greatest potential lies in the study of tephra deposits in well-dated high-resolution sedimentary records. Deep ocean sediment cores, such as ODP Site 1124-C, are ideal for this purpose. These stratigraphic layers are virtually instantaneous time-parallel marker horizons and are utilised in tephrochronological studies to aid and greatly enhance stratigraphic correlations, temporally linking sequences in different depositional settings (Alloway et al., 2007).

\subsubsection{Nomenclature}

“Tephra" (derived from the Greek tephra - 'ash') "is a collective term for all the unconsolidated, primary pyroclastic products of a volcanic eruption including all unconsolidated pyroclastic deposits irrespective of their origin or nature of emplacement" (Froggatt and Lowe, 1990). Froggatt and Lowe (1990) adopt this definition because it has a broader morphological meaning that negates the need to distinguish pyroclastic flow deposits from airfall deposits. 


\subsubsection{Review of Volcanic Ash Generation, Transportation and Deposition}

The fragmentation of magma generates ash-sized pyroclasts that are entrained in volcanic plumes and can be transported over great distances, to eventually deposit and mantle topography.

The following processes are known to generate volcanic ash during explosive volcanism.

1) Degassing of juvenile volcanic gases dissolved in magma at high pressure.

Exolution and expansion of dissolved gases in the magma can cause disruption and fragmentation of the magma in the top of the magma chamber in (i) volcanic vents during eruption, (ii) within plinian eruptive columns and (iii) in pyroclastic flows soon after eruption (Sparks, 1978; Self \& Sparks, 1978; Sparks et al., 1997).

2) Fragmentation can occur through the interaction of magma or hot pyroclasts with external water (ground, lake, crater lake or sea). This process can occur in (i) the top of the magma chamber, (ii) volcanic vents during eruption and (iii) soon after eruption if hot pyroclastic material enters a lake or the sea (Self \& Sparks, 1978; Walker, 1979; Sparks et al., 1997).

3) Physical/brittle fractionation caused by attrition and abrasion of larger solidified pyroclasts during eruption and transport can form ash-sized particles. This can occur in (i) volcanic vents, (ii) within plinian eruptive columns during eruption and (iii) in pyroclastic flows soon after eruption (Sparks et al., 1978; Sparks et al., 1997).

4) Some combination of (1), (2) and (3).

The volcanic ash deposits studied in this thesis were deposited in a marine environment hundreds of kilometres from their source. There are three routes through which volcanic ash can be transfered into the marine environment (Figure 1.5).

1) Atmospheric turbulent diffusion and the subsequent fallout from the spreading and dispersal of volcanic plumes. In this case, eruption cloud and wind turbulence supports fragments before settling through the atmosphere and through water down-wind of the eruption column.

2) Fallout from abrasion within ballistic trajectory resulting in a constant rain of ash settling through the atmosphere and through water down-wind of the eruption column. 
3) Pyroclastic flows, lahars or ash-charged rivers that discharge into the ocean.

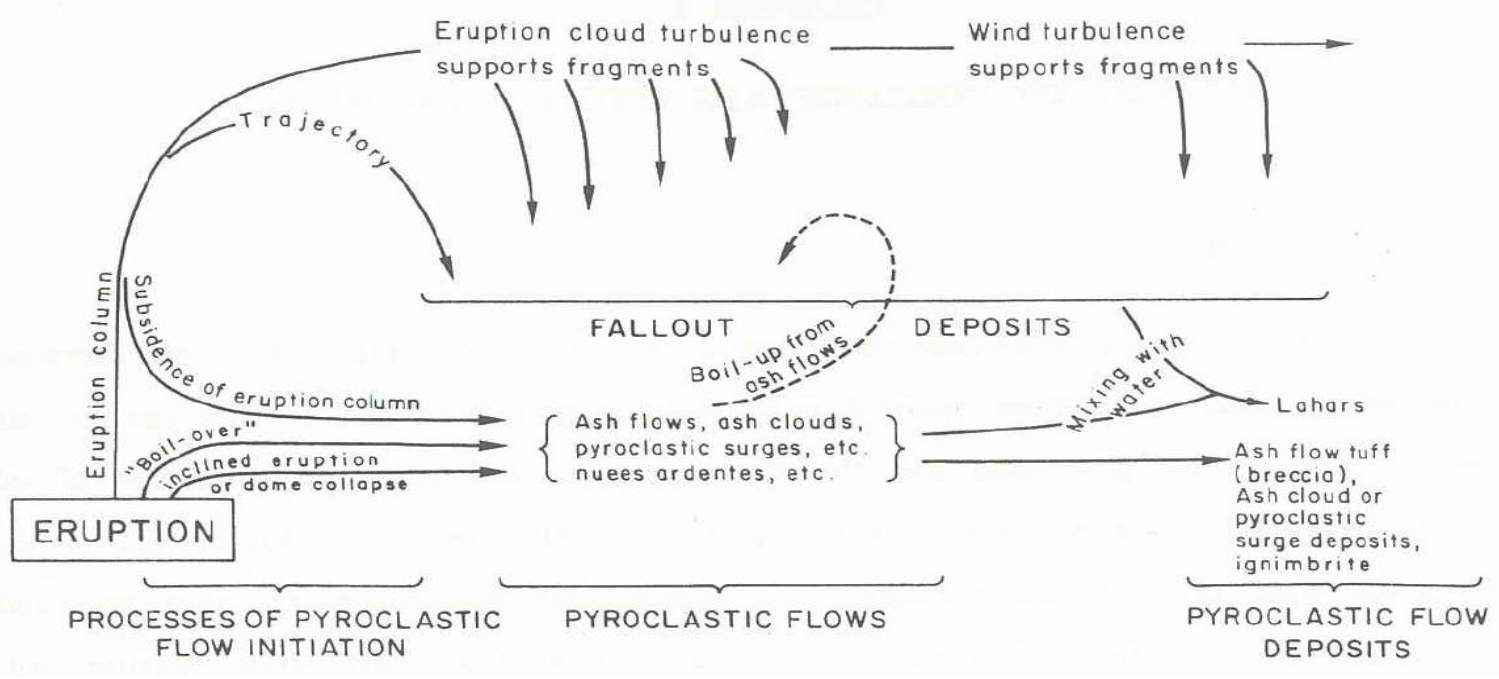

Fig. 1.5: Summary of the routes pyroclastic ejecta can follow after eruption (from Fisher \& Schmincke, 1984).

Fallout from the spreading and dispersal of volcanic plumes within the atmosphere and the subsequent settling through the atmosphere and through water is the only process listed above that would result in the deposition of the volcanic ash examined in this study. The location of Site 1124-C on a bathymetric high well above turbidity current pathways supports the settling of volcanic ash from atmospheric fallout and highlights the lack of a turbidity current origin (supported by other evidence as in Carter et al., 2004). The extent of an ash fall is initially determined by eruption parameters at the vent source, and these include magma composition, vent configuration, volume of eruption, eruption column height and duration of eruption. Once the volcanic plume has formed, the distribution and depositional pattern of volcanic ash is typically directed by wind direction and intensity governed by the complex layered arrangement of the atmosphere (e.g. Sigurdsson et al., 1980; Carter et al., 2004).

Volcanic ash settling through the atmosphere would be expected to blanket a large area of the sea surface and settle through the water column to mantle the sea floor. However, from its point of entry into the sea, several processes can control volcanic ash deposition into a deep marine setting. Ash on the sea surface can be transported by surface currents, by deeper flows during sedimentation through the water column (Lisitzin, 1972), or by bottom currents and bioturbation as it rests on the sea floor. These processes act to redistributed cohesionless sediment, modifying the thickness and continuity of volcanic ash on the sea floor. 


\subsubsection{Tephra Fall Deposits}

Tephra from volcanic plumes can be very widespread over land and sea. These deposits drape the topography with a uniform thickness at a local scale (although this is not supported for deposits in a marine setting (e.g. Manville and Wilson, 2004)) and provide a record of explosive volcanism in the geological past. Tephra layers are rapidly deposited over a relatively short geologic time interval (hours, days, weeks) and may define isochronous surfaces (e.g. Sparks et al., 1997).

Tephra fall deposits thin exponentially with distance from the source eruption (e.g. Sparks et al., 1997). Physical processes act to influence the variation among component abundances with decreasing proximity to the volcanic source. Distal tephra deposits, such as those preserved in deep sea sediment cores, may not yield enough material to allow the bulk analysis of mineral or glass separates. This suggests that it is unrealistic to use the bulk chemical composition of a tephra fall deposit for correlation studies over large distances. For this reason a single primary phase is commonly targeted for geochemical characterisation, typically glass shards but also mineral phases such as Fe-Ti oxides, pyroxenes, amphiboles and micas (Pearce et al., 2007). Analytical geochemical techniques with the premise of analysing bulk samples were considered unsuitable for analysis of the silicic tephras in this study and were not undertaken for the following reasons:

1) Physical processes during transport and deposition act to influence the variation among component abundances with increasing distance from the eruption source. The chemical composition will be dictated (laterally) by the variability in mineral concentrations resulting from mineral sorting within individual tephra layers. Quantitative determinations were not made of the mineral abundances because sorting would have made quantitative values meaningless.

2) Chemical contamination as a result of abundant non-volcanogenic material in each of the tephra layers (enclosing mud-rich sediment, bioclasts of foraminifera and diatoms).

3) Evidence of clay minerals and/or devitrified glass (e.g. smectite) indicating chemical alteration of the glass and/or minerals in the tephra layers.

Dating of tephras is critical to their use as chronostratigraphic time-parallel marker horizons. In New Zealand several dating techniques have been used. Tephra fall deposits 
have tended to be primarily dated by radiocarbon techniques (<40 ka) (TVZ) (Froggatt and Lowe, 1990) and fission track techniques (CVZ) (Shane et al., 1998). Tephra fall layers can also be dated by direct methods, including luminescence dating (Alloway et al., 1993); or by indirect dating methods such as magnetostratigraphy (Alloway et al., 2004; Carter et al., 2004), dendrochronology (Hogg et al., 2003), correlating tephra deposits to astronomically tuned deep sea sediment cores (Alloway et al., 2005) and by their position within a sedimentary chronostratigraphic framework. Although not widely applied to CVZ tephras, K-Ar dating has been used to date onshore eruptive units exposed along the Coromandel Peninsula (Adams et al., 1994; Takagi, 1995). Alternatively, the ${ }^{40} \mathrm{Ar} /{ }^{39} \mathrm{Ar}$ dating method provides the opportunity to obtain high precision ages on young tephra deposits outside the age range of radiocarbon dating (e.g. Houghton et al., 1995; Shane, 2000; Alloway et al., 2007). Although the ${ }^{40} \mathrm{Ar} /{ }^{39} \mathrm{Ar}$ technique has not been widely applied to distal tephras in New Zealand (Shane, 2000), it has been used to date onshore silicic volcanic rocks to better understand the evolution and transition between volcanism in the CVZ and TVZ (Briggs et al., 2005).

\subsection{Geochemical Evaluation of ODP Site 1124-C Tephra Layers}

The study of the chemical variations among tephras and the interpretation of the causative petrogenetic processes in magma generation form a significant part of this thesis. Magmas typically occur as distinct compositional suites that suggest a genetic relationship between end member compositions. The most important igneous processes that produce the variations in the geochemical signatures exhibited by igneous rocks are (i) partial melting of source rocks, (ii) the chemical differentiation of magma by crystallisation, (iii) melting and assimilation of crustal rocks by magmas and (iv) mixing of magmas variably affected by (i), (ii) and (iii). The resulting volcanic deposits record the magma chamber chemistry just prior to eruption, with the volcanic glass shards representing rapidly chilled glass that is a pristine sample of melt compositions. 


\subsubsection{Electron Probe Microanalysis (EPMA)}

The development and testing of the electron microprobe at the University of Alberta, Canada in the 1960s permitted, for the first time, the chemical characterisation of individual volcanic glass shards (Smith and Westgate, 1969; Smith et al., 1969). Since then, electron probe microanalysis (EPMA) has provided considerable advances in tephrochronological and petrogenetic studies and remains the standard technique for characterising the major element geochemistry of glass shards. Whilst EPMA has been adapted to the tephra problem, this method has limitations (see Section 2.3). Analyses are restricted to major and minor elements, with the EPMA unable to resolve major element variability in some suites of related tephra. These remarkably similar major element chemistries preclude correlation attempts (e.g. Alloway et al., 2007), although efforts to do so have been attempted (e.g. Shane et al., 1995; Allan et al, 2008), and little information can be extracted regarding magmatic processes.

\subsubsection{Laser Ablation Inductively Coupled Plasma Mass Spectrometry (LA- ICP-MS)}

LA-ICP-MS analytical techniques enable analysis of a wider range of elements and hence allow more diagnostic tephra geochemical fingerprinting. Trace element abundances are more sensitive to magmatic processes, such as the partial melting of source rocks, the chemical differentiation of magma by crystallisation, melting and assimilation of crustal rocks by magmas, and mixing of magmas that may leave major elements relatively unaffected. Magmatic processes that produce variations in major elements may vary by no more than an order of magnitude (e.g. $\mathrm{SiO}_{2}$ from $\sim 40$ to $\sim 80$ weight percent (wt. \%), Le Maitre (1984)), whereas trace element concentrations may vary by several orders of magnitude. Trace element fingerprinting of single shards of volcanic glass from tephras may thus provide a more robust method for characterising, correlating and interpreting the evolution of tephras and associated magmas that display almost indistinguishable major element chemistries. 
LA-ICP-MS is well suited to tephra studies because it has the advantage of providing rapid, high quality analyses with spatial resolution suited to the use of smaller glass shards (Pearce et al., 2004; Alloway et al., 2007). In order for the LA-ICP-MS technique to be employed, all glass shards must first be analysed by EPMA (Section 2.4.1) with probed glass shards subsequently re-analysed by LA-ICP-MS (Section 2.3). Recent applications of single shard LA-ICP-MS analyses have emphasised particular aspects that best illustrate the benefits of this technique when applied to tephrological studies (e.g. Bryant et al., 1999; Pearce et al., 1999; 2007).

Examination of time-resolved LA-ICP-MS data also enables the analyst to pin-point the exact moment in time when accidental contamination may have occurred during LA-ICPMS analysis, resulting from the inadvertent ablation of micro-phenocrysts below the glass surface or inclusions within the glass (Pearce et al., 2002; Harangi et al., 2005). By carefully checking the time-resolved signals, data quality is improved via recognition of potential contamination during analysis. Conducting single-shard trace element analysis also enables the presence of one or more populations of volcanic glass within a single tephra deposit to be identified (Shane, 2000). Bimodal compositional populations may occur either due to eruptive processes whereby relict older material becomes entrained into younger eruptive events, an artefact resulting from post-depositional sedimentary processes where two or more tephras become reworked or bioturbated, or may reflect a real compositional magmatic signal just prior to eruption. Intra-tephra geochemical heterogeneity and petrogenetic information is preserved when single glass shards are analysed (as opposed to bulk analysis techniques) (Shane et al., 2008).

In this thesis, both the EPMA and LA-ICP-MS techniques are used to measure the major and trace element composition of all 72 Miocene to Pliocene silicic tephras for ODP core 1124-C. 


\subsection{Objectives of this Thesis}

The following characteristics make the ODP Site 1124-C tephra record appealing as a potential type-section for late Miocene to Pliocene tephrochronologic studies in New Zealand:

1) The record spans $\sim 10$ to $2 \mathrm{Ma}$ of the CVZ history.

2) Site 1124-C has an exceptional palaeomagnetic age model.

3) Site $1124-\mathrm{C}$ is the most complete recovery of late Miocene to Recent marine tephras yet obtained for New Zealand, in comparison to the fragmentary onshore CVZ record.

4) The tephra layers contain pristine shards of volcanic glass ideal for geochemical characterisation, perfect for generating a new framework for correlation between offshore and onshore late Cenozoic sedimentary sequences.

5) The Site 1124-C record reaches the temporal transition from the CVZ to TVZ, providing an opportunity to evaluate any geochemical differences between the CVZ and TVZ Quaternary silicic tephras and potentially shed light on any change in magma generation processes.

The following approach will be taken to this thesis:

1) To establish a geochemical stratigraphy of all Miocene to Pliocene silicic ash deposits in the marine sedimentary sequence from ODP Site 1124-C.

2) To assess the ability of geochemical fingerprinting to characterise individual volcanic ash deposits and to generate a new stratigraphic framework for correlation between offshore and onshore late Cenozoic sedimentary sequences.

3) Aims one and two will help appraise and refine the ODP Site 1124-C tephrostratigraphic record as a means of reconstructing a new and more complete explosive volcanic history of silicic volcanism from the extinct CVZ.

4) Utilisation of diagnostic trace element variability within individual volcanic ash deposits to elucidate possible mechanisms involved in the petrogenesis of CVZ derived magmas.

5) To evaluate the transition from CVZ to TVZ arc volcanism 


\subsection{Thesis Structure}

This thesis consists of five chapters and three appendices in the following structure:

\section{Chapter One: Introduction}

The introduction outlines the regional tectonic setting of New Zealand relating to the volcanic evolution of the CVZ. A brief discussion of the onshore record is followed by a discussion of the potential CVZ volcanic record recovered at ODP Site 1124-C. Current understanding of tephrostratigraphy and tephrochronology is presented. Geochemical evaluation of tephras recovered at ODP Site 1124-C is discussed.

\section{Chapter Two: Sample Preparation and Analytical Techniques}

Sample preparation and analytical procedures are described with presentation of major and trace element standard data acquired during analysis. A brief overview of existing major and trace element data for CVZ tephras is given with respect to the analytical methods employed.

\section{Chapter Three: Results}

Presentation of representative figures for single glass shard major, minor and trace element data acquired for CVZ tephras.

\section{Chapter Four: Discussion}

Understanding the implications of intra-tephra variation is outlined. A new temporal geochemical evolution of the CVZ is established with implications for plate tectonic reconstructions and the CVZ/TVZ transition. What single glass shard geochemistry implies about the petrogenetic history of CVZ magmas is discussed. New Li and B data is put into context for the petrogenesis of arc magmas while assessing the slab-to-mantle transfer of subduction zone signatures. 


\section{Chapter Five: Synthesis and Conclusions}

Project achievements and potential future work are described.

\section{Appendix One: Ocean Drilling Program Site 1124 Tephras}

Spreadsheet of individual tephra layers recovered at ODP Site 1124-C from the Shipboard Scientific Party (1999).

\section{Appendix Two: Major Element Data measured by Electron Probe Microanalysis}

Mean major element data for individual tephra layers. In cases where multiple geochemical glass shard populations were identified in a single tephra layer, a separate mean has been calculated and attributed to each population.

\section{Appendix Three: Trace Element Data measured by Laser Ablation Inductively Coupled Plasma Mass Spectrometry}

Mean trace element data for individual tephra layers. In cases where multiple geochemical glass shard populations were identified in a single tephra layer, a separate mean has been calculated and attributed to each population. 


\subsection{Sample Preparation and Analytical Techniques}

\subsection{Sample Acquisition}

The 76 tephra samples analysed in this study were obtained from the Integrated Ocean Drilling Program (IODP) Gulf Coast Repository (Texas, USA). Samples were extracted from discrete tephra layers and it is believed they were preferentially taken from coarser grained layers where possible. All the tephra samples are considered to be from primary airfall deposits (see Section 1.4.2). Thirteen tephra samples analysed in this study have been allocated the sample numbers used previously by Carter et al. (2004), and are presented in conjunction with the sample numbers assigned here (Appendix One).

\subsection{Sample Preparation}

Volcanic glass from each tephra was separated from the bulk sample and mounted in 5mm-thick, half-circle epoxy resin blocks for microanalytical geochemical characterisation by EPMA (major elements) and LA-ICP-MS (trace elements) (Figure 2.1). Bulk tephra samples were wet sieved through a $33 \mu$ m nylon mesh to remove surplus mud. Rinsing with water produced a residue of $>90 \%$ volcanic glass shards with the remainder comprising feldspar, quartz, biotite, Fe-Ti oxides and bioclasts (foraminifera, diatoms) of varying proportions. The separated glass was rinsed several times with water and left to dry at $50{ }^{\circ} \mathrm{C}$ for $24-48 \mathrm{hr}$. Volcanic glass shard samples require mounting so that the specimen is supported in a secure medium for grinding and polishing prior to analysis. Epoxy resins are preferable for this purpose as they have the best characteristics with respect to hardness and shrinkage, although epoxy resins are slow curing and take a considerable amount of time to develop full hardness (typically $>24 \mathrm{hr}$ ). Epoxy resin and hardener were mixed at a ratio of 3:1 and mounts were prepared using standard plastic moulds and cut into 5-mm-thick half-circles. Two holes were drilled in the epoxy, approximately $4.5 \mathrm{~mm}$ in diameter and $5 \mathrm{~mm}$ apart. Only one tephra was mounted in each epoxy block to avoid the possibility of cross-contamination with any adjacent samples (c.f. Gosson, 1986). An in-house obsidian standard was mounted alongside each tephra. 
This was used as a grain-size comparator when locating the volcanic glass in each mount through the optical lens during EPMA (Figures 2.1 (A) and (B)). The epoxy blocks were ground down using wet 400 - $4000 \mu \mathrm{m}$ grit silicon carbide paper to expose the glass shards and then polished using $3 \mu \mathrm{m}$ and $1 \mu \mathrm{m}$ liquid diamond suspension on a polishing wheel. A $25 \mathrm{~nm}$ coating of carbon film was applied to each mount prior to major element characterisation by EPMA to make the surface of the medium conductive (Figure 2.1 (B)). Coating was carried out at Victoria University of Wellington to ensure the thickness of the carbon film on each sample was the same as on the standards analysed residing within the electron microprobe (see below). The carbon coating was removed using analytical grade methanol prior to LA-ICP-MS analysis.

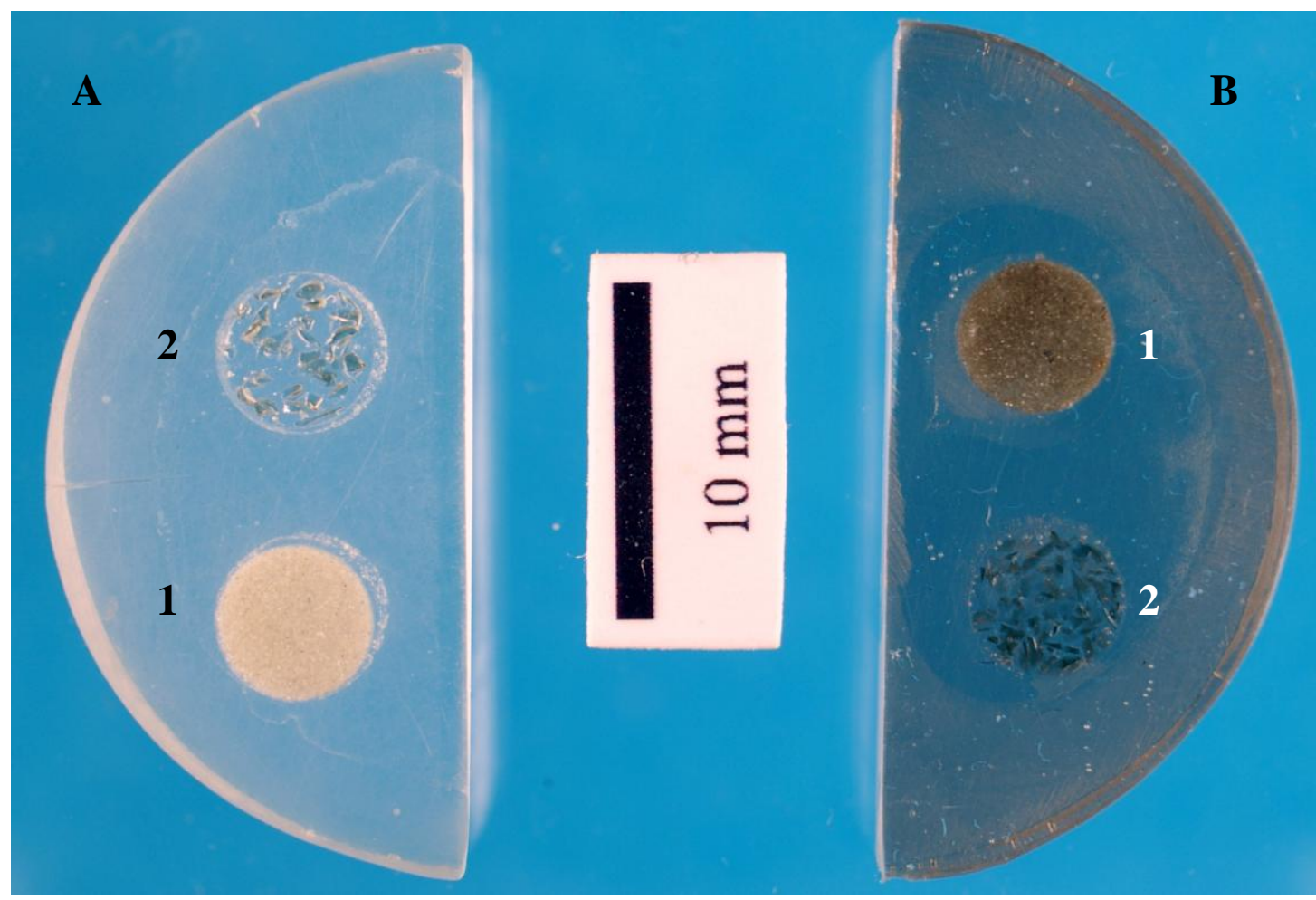

Fig. 2.1: Natural light photograph of two $5 \mathrm{~mm}$ thick, half-circle epoxy resin blocks containing (1) a residue of $>90 \%$ volcanic glass shards after sieving and, (2) an in-house obsidian standard. (A) Sample mount prior to and after EPMA major element characterisation and, (B) Sample mount with a $25 \mathrm{~nm}$ coating of carbon film applied for major element characterisation. 


\subsection{Electron Probe Microanalysis (EPMA)}

The major element composition $\left(\mathrm{SiO}_{2}, \mathrm{TiO}_{2}, \mathrm{Al}_{2} \mathrm{O}_{3}, \mathrm{FeO}, \mathrm{MgO}, \mathrm{CaO}, \mathrm{Na}_{2} \mathrm{O}, \mathrm{K}_{2} \mathrm{O}\right.$ and $\left.\mathrm{Cl}\right)$ of small portions of single shards of volcanic glass was determined using a JEOL 733 Superprobe fitted with three wavelength dispersive X-ray spectrometers at Victoria University of Wellington, New Zealand. Analytical conditions are outlined in Table 2.1. The elemental composition for each glass shard is processed through a ZAF calculation correction method. Inelastic electron scattering and energy loss related to atomic number (Z), absorption of X-rays by the sample (A) and a fluorescence X-ray correction (F) are accounted and corrected for in each analysis. Analyses were performed under a static electron beam defocused to $20 \mu \mathrm{m}$, operating at $8 \mathrm{nA}$ with an accelerating voltage of 15 $\mathrm{keV}$.

The alkalis $\left(\mathrm{Na}_{2} \mathrm{O}\right.$ and $\left.\mathrm{K}_{2} \mathrm{O}\right)$ were analysed first during each glass shard analysis to minimise any significant reduction (alkali loss) in the peak count rate resulting from glass instability associated with electron beam heating and damage of the glass-shard matrix (Nielson and Sigurdsson, 1981; Hunt and Hill, 2001). Alkali mobility is directly related to the flux of electrons arriving at the sample surface, and modification of beam current and beam diameter has the capacity to minimise the effective alkali loss (Hunt and Hill, 2001), and is reflected in the electron probe analytical parameters used in this study (see above). Smith and Westgate (1969), Smith et al. (1969), Sweatman and Long (1969) and Potts et al. (1983) provide a more comprehensive appraisal of EPMA than is available in this thesis. To enable comparison of the major element composition of the tephras, all analyses were normalised to $100 \mathrm{wt}$. \% on an anhydrous basis with the deficiency in the total assumed to represent magmatic volatiles (e.g. $\mathrm{H}_{2} \mathrm{O}$ ), varying degrees of secondary hydration experienced by the glass and/or minor elements not analysed. Analytical totals for individual glass shards were typically in the range of $91.0-99.0 \mathrm{wt}$. \%; data with very low totals $(<91.0$ wt. \%) have been removed from the dataset. All Fe is expressed as FeO. A back-scattered electron image of each tephra sample (e.g. Figure 2.2) was taken during major element characterisation to ensure that each individual glass shard measured by EPMA could also be analysed for its trace element composition by LA-ICP-MS. 


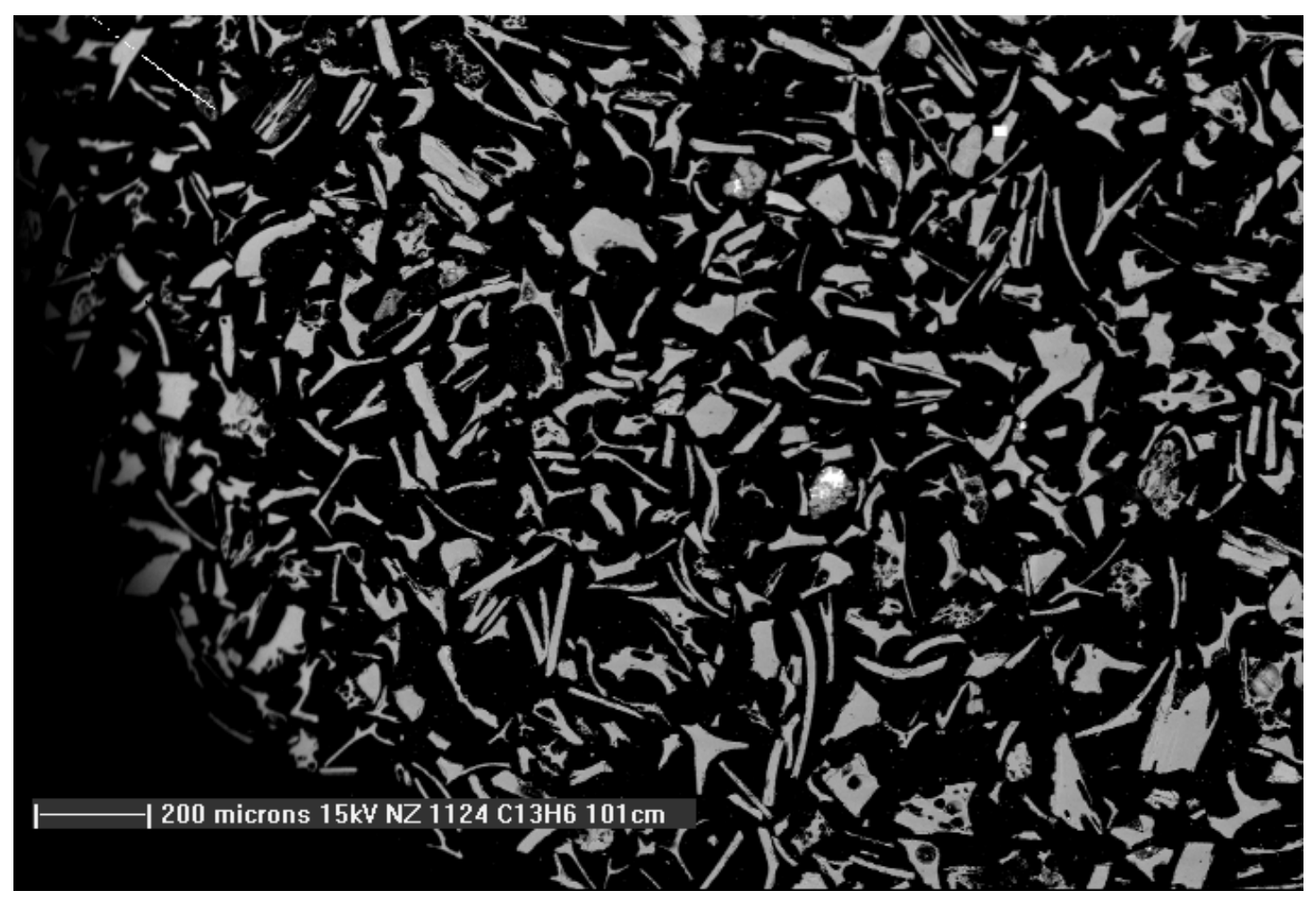

Fig. 2.2: Back-scattered electron (BSE) image of sample M-48 $1124 \mathrm{C} 13 \mathrm{H} 6101 \mathrm{~cm}$ taken during major element characterisation by EPMA. Scale bar represents $200 \mu \mathrm{m}$.

\begin{tabular}{ll}
\hline EPMA system & JEOL 733 Superprobe \\
Spectrometers & 3 x wavelength dispersive spectrometers \\
Correction method & $\mathrm{ZAF}$ \\
Beam mode & $\mathrm{Static}$ spot \\
Spot size & $20 \mu \mathrm{m}$ only \\
Accelerating voltage & $15 \mathrm{keV}$ \\
Beam current & $8 \mathrm{nA}$ \\
Elements analysed & $\mathrm{SiO}_{2}, \mathrm{TiO}_{2}, \mathrm{Al}_{2} \mathrm{O}_{3}, \mathrm{FeO}, \mathrm{MgO}, \mathrm{CaO}$, \\
& $\mathrm{Na}_{2} \mathrm{O}, \mathrm{K}_{2} \mathrm{O}$ and $\mathrm{Cl}$ \\
Normalisation & $100 \%$ anhydrous \\
& \\
Standards and calibration & \\
Monitored standardising elements & $\mathrm{Natural}: \mathrm{Si}, \mathrm{Ca}, \mathrm{Na}, \mathrm{K}, \mathrm{Cl}$ \\
& $\mathrm{Synthetic}: \mathrm{Al}, \mathrm{Mg}, \mathrm{Ti}, \mathrm{Fe}$ \\
Calibration standard & VG-A99 Basaltic Glass \\
\hline
\end{tabular}

Table 2.1: EPMA instrumental and analytical operating parameters. 


\subsubsection{Precision and Accuracy of Major Element Data}

The electron microprobe in this study was calibrated daily using standard minerals of known composition. A wide range of natural and synthetic standards were utilised, mounted on a standard bar which resides within the instrument: $\mathrm{Si}$ and $\mathrm{Ca}$ - wollastonite; $\mathrm{Na}$ - jadeite; $\mathrm{K}$ - orthoclase; $\mathrm{Cl}$ - sodalite; $\mathrm{Al}, \mathrm{Mg}, \mathrm{Ti}, \mathrm{Fe}$ - synthetic. It is important to use a standard that can be used reliably for monitoring the precision, and thus the reproducibility, of the electron microprobe analyses obtained from tephra glass. The homogeneous basaltic reference glass VG-A99 was continuously measured between samples to monitor the precision and accuracy of the major element data. With the exception of $\mathrm{Cl}$, due to the very low concentration of this element in VG-A99, all other elements listed in Section 2.3 were measured to monitor the precision and accuracy of major element data acquired during this study (Table 2.2). Based on repeated analyses (n =286), the basaltic reference glass VG-A99 yielded major element abundances that agree to within $\pm 2.7 \%$ of the preferred reference values (Jarosewich et al., 1979). The day-today precision of EPMA major element concentrations is reflected in the repeated measurements of VG-A99: $\mathrm{SiO}_{2} \pm 4.2 \% ; \mathrm{Al}_{2} \mathrm{O}_{3} \pm 4.8 \% ; \mathrm{TiO}_{2} \pm 7.1 \% ; \mathrm{FeO} \pm 5.6 \%$; $\mathrm{MgO} \pm 4.7 \% ; \mathrm{CaO} \pm 5.4 \% ; \mathrm{Na}_{2} \mathrm{O} \pm 8.1 \%$ and $\mathrm{K}_{2} \mathrm{O} \pm 13.7 \%$ (2 sd relative).

\begin{tabular}{lccccc}
\hline & \multicolumn{6}{c}{ Basaltic Glass VG-A99 } & (USNM113498/1) & $(\mathbf{n}=\mathbf{2 8 6})$ & \\
& $\begin{array}{c}\text { Jarosewich et } \\
\text { al. (1979) }\end{array}$ & Mean & $2 \mathrm{SD}$ & $\begin{array}{c}\text { Precision } \\
\text { (\% 2 sd) }\end{array}$ & $\begin{array}{c}\text { Accuracy } \\
\text { (\% diff.) }\end{array}$ \\
\hline $\mathrm{SiO}_{2}$ & $\mathbf{5 0 . 9}$ & 50.7 & 2.12 & 4.2 & -0.5 \\
$\mathrm{TiO}_{2}$ & $\mathbf{4 . 0 6}$ & 4.07 & 0.61 & 7.1 & 0.8 \\
$\mathrm{Al}_{2} \mathrm{O}_{3}$ & $\mathbf{1 2 . 5}$ & 12.6 & 0.29 & 4.8 & 0.2 \\
$\mathrm{FeO}$ & $\mathbf{1 3 . 3}$ & 13.2 & 0.74 & 5.6 & -0.4 \\
$\mathrm{MgO}$ & $\mathbf{5 . 0 8}$ & 5.22 & 0.25 & 4.7 & 2.7 \\
$\mathrm{CaO}$ & $\mathbf{9 . 3 0}$ & 9.11 & 0.49 & 5.4 & -2.1 \\
$\mathrm{Na}$ & $\mathbf{2 . 6 6}$ & 2.69 & 0.22 & 8.1 & 1.2 \\
$\mathrm{~K} 2 \mathrm{O}$ & $\mathbf{0 . 8 2}$ & 0.82 & 0.11 & 13.7 & 0.1 \\
$\mathrm{TOTAL}$ & $\mathbf{9 8 . 7}$ & 98.4 & & & \\
\hline
\end{tabular}

Table 2.2: EPMA precision and accuracy for international basaltic glass standard VGA99. Notes: values are calculated from daily repeated analyses $(n=286)$. Jarosewich et al. (1979) preferred values, means and 2 standard errors (this study) are reported in wt. \%. 


\subsubsection{Existing Major Element Data for Miocene-Pliocene Coromandel Volcanic Zone Tephras}

Apart from the work of Gosson (1986), Shane (1990), Naish et al. (1996), Shane et al. (1998) and Carter et al. $(2003 ; 2004)$ little has been published on the geochemistry of volcanic glass shards of Miocene-Pliocene tephra derived from the CVZ. EPMA has remained the most common grain-specific technique in previous studies for distinguishing between tephra layers and allowing chronologies and correlations over large distances to be established. Table 2.3 outlines the most important instrumental and analytical operating parameters employed by each study mentioned above. Unfortunately, these previous studies did not document data for a well-characterised standards, inhibiting the comparison of tephra geochemical data (both major and trace elements) acquired from different microanalytical instruments, which may have been operated under different parameters. Complexity is compounded further by the publication of normalised data without an indication of assumed volatile content (e.g. water), thereby losing any recognition of the potential effects of alkali loss and the potential enhancement of the higher abundance elements (e.g. $\mathrm{Si}, \mathrm{Al}$ ). It is beneficial to emphasise the need to display representative geochemical analyses of a secondary homogeneous glass standard, acquired during the same analytical session, alongside sample data. 


\begin{tabular}{|c|c|c|}
\hline Study & $\begin{array}{l}\text { Type and Location of } \\
\text { Electron Microprobe }\end{array}$ & $\begin{array}{c}\text { Instrumental and } \\
\text { Analytical Operating } \\
\text { Parameters }\end{array}$ \\
\hline This study & $\begin{array}{l}\text { JEOL } 733 \text { Superprobe fitted } \\
\text { with } 3 \times \text { WDS } \\
\text { Victoria University of } \\
\text { Wellington }\end{array}$ & $\begin{array}{c}20 \mu \mathrm{m} \text { only } \\
15 \mathrm{keV} \\
8 \mathrm{nA}\end{array}$ \\
\hline Gosson (1986) & $\begin{array}{l}\text { JEOL } 733 \text { Superprobe fitted } \\
\text { with } 3 \times \text { WDS } \\
\text { Victoria University of } \\
\text { Wellington }\end{array}$ & $\begin{array}{l}10 \mu \mathrm{m} \text { only } \\
15 \mathrm{keV} \\
8 \mathrm{nA}\end{array}$ \\
\hline Shane (1990) & $\begin{array}{l}\text { JEOL } 733 \text { Superprobe fitted } \\
\text { with } 3 \times \text { WDS } \\
\text { Victoria University of } \\
\text { Wellington }\end{array}$ & $\begin{array}{l}10 \mu \mathrm{m} \text { only } \\
15 \mathrm{keV} \\
8 \mathrm{nA}\end{array}$ \\
\hline Shane et al. (1995) & $\begin{array}{l}\text { JEOL } 733 \text { Superprobe fitted } \\
\text { with } 3 \times \text { WDS } \\
\text { Victoria University of } \\
\text { Wellington }\end{array}$ & $\begin{array}{c}10 \text { or } 20 \mu \mathrm{m} \text { only } \\
15 \mathrm{keV} \\
8 \mathrm{nA}\end{array}$ \\
\hline Naish et al. (1996) & $\begin{array}{l}\text { JEOL } 733 \text { Superprobe fitted } \\
\text { with } 3 \times \text { WDS } \\
\text { Victoria University of } \\
\text { Wellington }\end{array}$ & $\begin{array}{l}20 \mu \mathrm{m} \text { only } \\
15 \mathrm{keV} \\
8 \mathrm{nA}\end{array}$ \\
\hline Shane et al. (1998) & $\begin{array}{l}\text { CAMEBAX SX-50 } \\
\text { University of Toronto }\end{array}$ & $\begin{array}{l}10 \mu \mathrm{m} \text { only } \\
15 \mathrm{keV} \\
10 \mathrm{nA}\end{array}$ \\
\hline Carter et al. $(2003 ; 2004)$ & $\begin{array}{l}\text { JEOL JXA- } 840 \text { probe fitted } \\
\text { with a PGT Prism } 2000 \text { EDS } \\
\text { detector } \\
\text { University of Auckland }\end{array}$ & $\begin{array}{l}15 \mu \mathrm{m} \text { only } \\
15 \mathrm{keV} \\
1.5 \mathrm{nA}\end{array}$ \\
\hline
\end{tabular}

Table 2.3: Instrumental and analytical operating parameters during EPMA of previous studies when determining the major element composition of single shards of volcanic glass from Miocene-Pliocene tephra derived from the CVZ, New Zealand. 


\subsection{Laser Ablation Inductively Coupled Plasma Mass Spectrometry (LA-ICP-MS)}

The trace element composition of single glass shards was determined using an Agilent 7500CS inductively coupled plasma mass spectrometer (ICP-MS) equipped with a New Wave 193 nm (deep UV) solid-state laser ablation system at Victoria University of Wellington, New Zealand. Analytical conditions are outlined in Table 2.4. Thirty nine minor and trace element abundances were determined by LA-ICP-MS: Li, B, Mg, Ca, Sc, Ti, V, Cr, Mn, Ni, Cu, Zn, Rb, Sr, Y, Zr, Nb, Cs, Ba, La, Ce, Pr, Nd, Sm, Eu, Gd, Tb, Dy, $\mathrm{Ho}, \mathrm{Er}, \mathrm{Tm}, \mathrm{Yb}, \mathrm{Lu}, \mathrm{Hf}, \mathrm{Ta}, \mathrm{W}, \mathrm{Pb}$, Th and $\mathrm{U}$. The carbon coating applied to the sample mounts for EPMA characterisation was removed prior to LA-ICP-MS analysis by cleaning with analytical grade methanol and ultra-clean Milli-Q water (>18.2 M 2 ). The cleaned sample mounts were placed in an oven at $50{ }^{\circ} \mathrm{C}$ until analysis, thus ensuring complete evaporation of any moisture held in void spaces in the epoxy resin and/or vesicular glass shards.

Laser ablation static spot analyses were attained using laser beam diameters of 20, 25 or 35 $\mu \mathrm{m}$ accommodating the variable widths of each single volcanic glass shard. The complete absorption of $193 \mathrm{~nm}$ radiation by colourless glass has been shown by Pearce et al. (2007) to produce a better particle size distribution, thus more of the sample reaches the plasma (Kuhn et al., 2004; Kuhn and Gunther, 2004). Helium was employed as the sample aerosol carrier gas during ablation following on from the studies of Eggins et al. (1998) and Guillong (2004) which showed that He increases the efficiency of sample aerosol transport from the ablation chamber to the ICP-MS, yielding a two-to-three fold increase in signal intensity and reduced background intensity across the entire mass range as compared to using Ar as the ablation gas. Helium was mixed with an Ar carrier gas flow directly after the ablation chamber. Potential interfering species on the measured signal intensities for each analyte isotope were minimised as the instrument was optimised for sensitivity and minimal molecular oxide production $\left(\mathrm{ThO}^{+} / \mathrm{Th}^{+}<1.5 \%\right)$ through optimisation of plasma torch conditions and, to a lesser extent, oven drying each sample preceding analysis (see above). 


\section{ICP-MS}

ICP-MS system

\section{Laser ablation}

Laser ablation system

Ablation mode

Laser Power

Spot size

Repetition rate

Passes

\section{Tuning}

Tuning standard

Ablation mode

Background

Tuning isotopes

Oxide interference

Carrier Gas (Argon)

Ablation Gas (Helium)

RF Power

\section{Standards and Calibration}

Calibration standard

Internal standard

Precision/Accuracy standard

\section{Method}

Background acquisition time

Sample/standard acquisition time

Washout time

Analyte isotopes and integration times
Agilent 7500CS

New Wave 193 nm (deep UV) solid state laser

Static spot

60 or $65 \%$

20,25 or $35 \mu \mathrm{m}$

$5 \mathrm{~Hz}$

$12 \times 5$ second passes, $3 \mu \mathrm{m}$ refocussing depth after each pass

\section{NIST 612}

Rastering at $2 \mu \mathrm{m} / \mathrm{s}$ beneath a $35 \mu \mathrm{m}$ spot

${ }^{29} \mathrm{Si}$, typically $<200 \mathrm{cps}$, always $<500 \mathrm{cps}$

${ }^{43} \mathrm{Ca}$, typically $<1500 \mathrm{cps}$, always $<2000 \mathrm{cps}$

${ }^{43} \mathrm{Ca},{ }^{89} \mathrm{Y},{ }^{140} \mathrm{Ce},{ }^{208} \mathrm{~Pb}$, typically $<5 \%$ RSD

for each isotope

$\mathrm{ThO}^{+} / \mathrm{Th}^{+}$, typically $<1.5 \%$

$0.85-0.95 \mathrm{~L} / \mathrm{min}$

$79-86 \%$

$1450-1500 \mathrm{~W}$

NIST 612

${ }^{29} \mathrm{Si}$

MPI-DING ATHO-G (Icelandic rhyolite)

$60 \mathrm{~s}$

$60 \mathrm{~s}$

$60 \mathrm{~s}$

$5 \mathrm{~ms}:{ }^{29} \mathrm{Si}$

$10 \mathrm{~ms}:{ }^{7} \mathrm{Li},{ }^{11} \mathrm{~B},{ }^{24} \mathrm{Mg},{ }^{43} \mathrm{Ca},{ }^{45} \mathrm{Sc},{ }^{51} \mathrm{~V},{ }^{53} \mathrm{Cr}$, ${ }^{55} \mathrm{Mn},{ }^{60} \mathrm{Ni},{ }^{63} \mathrm{Cu},{ }^{66} \mathrm{Zn},{ }^{85} \mathrm{Rb},{ }^{88} \mathrm{Sr},{ }^{89} \mathrm{Y}$, ${ }^{90} \mathrm{Zr},{ }^{93} \mathrm{Nb},{ }^{137} \mathrm{Ba},{ }^{139} \mathrm{La},{ }^{140} \mathrm{Ce},{ }^{141} \mathrm{Pr}$

$20 \mathrm{~ms}:{ }^{47} \mathrm{Ti},{ }^{133} \mathrm{Cs},{ }^{146} \mathrm{Nd},{ }^{147} \mathrm{Sm},{ }^{153} \mathrm{Eu},{ }^{157} \mathrm{Gd}$, ${ }^{159} \mathrm{~Tb},{ }^{163} \mathrm{Dy},{ }^{165} \mathrm{Ho},{ }^{166} \mathrm{Er},{ }^{169} \mathrm{Tm},{ }^{172} \mathrm{Yb}$, ${ }^{175} \mathrm{Lu},{ }^{178} \mathrm{Hf},{ }^{181} \mathrm{Ta},{ }^{182} \mathrm{~W},{ }^{208} \mathrm{~Pb},{ }^{232} \mathrm{Th}$, ${ }^{238} \mathrm{U}$

Table 2.4: LA-ICP-MS instrumental and analytical operating parameters. 


\subsubsection{LA-ICP-MS Data Acquisition and Calculation}

Data reduction was achieved by using background-subtracted count rates calculated from background count rates measured for $60 \mathrm{~s}$ prior to ablation. Each individual analysis corresponds to acquisition of $60 \mathrm{~s}$ of raw data during ablation before the glass shard was consumed. Individual glass shards were too small to allow preablation for any length of time; thus, raw data counts were recorded immediately after the laser beam was initiated (Pearce et al., 2008). A washout period of $60 \mathrm{~s}$ after ablation allowed for the return to representative background levels before the next analysis.

A homogeneous trace element standard is required for calibration purposes during LAICP-MS. Individual trace element abundances of the sample were calculated relative to the analysis of a bracketing homogeneous reference glass standard (NIST 612), which was analysed under identical operating conditions (Table 2.3) throughout each sample run. NIST $612\left(\mathrm{SiO}_{2}=71.9 \%\right)$ was chosen as the calibration standard in this study as it is ideal for the reference material to have a close matrix match to the ablating sample material. Tests conducted in a recent study undertaken at Victoria University of Wellington have shown that NIST 612 is suitably matrix-matched for the analysis of rhyolitic glass in order for the LA-ICP-MS method to accurately determine the trace element abundances in the sample (Allan, 2008). This was verified again in this study.

The LA-ICP-MS secondary data normalisation technique utilised in this study follows that of Pearce et al. (1996) (modified from earlier work by Westgate et al., 1994), where the minor isotope of a major element previously determined by EPMA, is included within the analyte isotopes and employed as an internal standard $\left({ }^{29} \mathrm{Si}\right.$ in this study). Tests conducted in the early stages of LA-ICP-MS data acquisition (see Section 2.4.2.1 below) have shown

${ }^{29} \mathrm{Si}$ to be a more effective internal standard than ${ }^{43} \mathrm{Ca}$ for secondary data normalisation, and thus ${ }^{29} \mathrm{Si}$ was used as the internal standard for calculating all trace element abundances of the rhyolitic glasses analysed in this research. 
Using background subtracted count rates, the concentration of trace element $\mathrm{x}$ in a single volcanic glass shard is determined by the following relationship:

$$
\begin{aligned}
& \mathrm{C}_{\text {glass }}^{\mathrm{SiO}_{2} \text {,LA-ICP-MS }}=\mathrm{C}_{\text {std }}^{\mathrm{SiO}_{2}} \times\left(\mathrm{CPS} \underset{\text { glass }}{\mathrm{Si}} / \mathrm{CPS} \text { std }_{\text {st }}^{\mathrm{Si}}\right) \\
& \mathrm{C}_{\text {glass }}^{\mathrm{x} \text {,LA-ICP-MS }}=\mathrm{C}_{\text {std }}^{\mathrm{x}} \mathrm{x}\left(\mathrm{C}_{\text {glass }}^{\mathrm{SiO}_{2} \text {,EPMA }} / \mathrm{C}_{\text {glass }}^{\mathrm{SiO}_{2}, \mathrm{LA}-\mathrm{ICP}-\mathrm{MS}}\right) \mathrm{x}\left(\mathrm{CPS}_{\text {glass }}^{\mathrm{x}} / \mathrm{CPS}_{\text {std }}^{\mathrm{x}}\right)
\end{aligned}
$$

$\mathrm{C}_{\text {glass }}^{\mathrm{SiO}_{2} \text {,LA-ICP-MS }}, \mathrm{C}_{\text {glass }}^{\mathrm{SiO}_{2}, \mathrm{EPMA}}=\mathrm{SiO}_{2}$ concentration of an individual glass shard determined by LA-ICP-MS or EPMA.

$\mathrm{C}_{\text {std }}^{\mathrm{SiO}_{2}}=$ GeoReM reference value for $\mathrm{SiO}_{2}$ concentration of the NIST 612 standard.

$\mathrm{CPS}_{\text {glass }}^{\mathrm{Si}}, \mathrm{CPS} \mathrm{std}_{\mathrm{Si}}^{\mathrm{Si}}=$ counts per second achieved for ${ }^{29} \mathrm{Si}$ during laser ablation of an individual glass shard (glass) or NIST 612 standard (std).

$\mathrm{C}_{\text {glass }}^{\mathrm{x}, \mathrm{LA}-\mathrm{ICP}-\mathrm{MS}}=$ concentration of trace element $\mathrm{x}$ of an individual glass shard determined by LA-ICP-MS.

$\mathrm{C}_{\text {std }}^{\mathrm{x}}=$ GeoReM reference value for trace element $\mathrm{x}$ concentration of the NIST 612 standard.

$\operatorname{CPS}_{\text {glass }}{ }^{\mathrm{x}}, \mathrm{CPS}_{\text {std }}^{\mathrm{x}}=$ counts per second achieved for an isotope of trace element $\mathrm{x}$ during laser ablation of an individual glass shard (glass) or NIST 612 standard (std).

To ensure that calculated trace element abundances in this dataset correspond to pure glass shard material, all time-resolved LA-ICP-MS data have been checked to remove analyses that were compromised by the inadvertent ablation of micro-phenocrysts below the glass surface or inclusions within the glass.

\subsubsection{Precision and Accuracy of Trace Element Data}

The homogeneous rhyolitic glass standard ATHO-G was repeatedly measured on the LAICP-MS to monitor the precision and accuracy of the trace element data acquired during this study (Table 2.5). Upon close inspection of the ${ }^{29} \mathrm{Si}$ and ${ }^{43} \mathrm{Ca}$ normalised trace element data acquired from analyses $(n=43)$ of the rhyolitic reference glass ATHO-G it was realised that five analyses were compromised by high background (gas blank) levels linked to instrument maintenance prior to the analytical session and have thus been discarded from the mean trace element abundances discussed below. During the same analytical session the following tephra samples were analysed (M-40, M-42, M-50, M-52, M-53, M54, M-55, M-56, M-57), these analyses remain within the dataset discussed herein due to time constraints preventing re-analysis of these samples. Based on repeated analyses $(n=$ 
38) the rhyolitic reference glass ATHO-G yielded mean trace element abundances of B, $\mathrm{Ca}, \mathrm{Mn}, \mathrm{Rb}, \mathrm{Sr}, \mathrm{Y}, \mathrm{Ba}, \mathrm{La}, \mathrm{Ce}, \mathrm{Pr}, \mathrm{Nd}, \mathrm{Sm}, \mathrm{Eu}, \mathrm{Gd}, \mathrm{Tb}, \mathrm{Yb}, \mathrm{Lu}, \mathrm{Hf}$ and $\mathrm{U}$ that fall within \pm $5 \%$ of the stated reference values of Jochum et al. (2006) (Figure 2.3 (A)). The mean trace element abundances determined for Li, Ti, Zn, Zr, Nb, Dy, Ho, Er, Tm, Ta, W, Pb and Th agree to within $\pm 5-10 \%$ of the stated reference values of Jochum et al. (2006) (Figure 2.3 (A)). Considerable discrepancies from the certified values (Jochum et al., 2006) have been recognised for several of the comparatively low concentration elements analysed ( $\mathrm{Mg}, \mathrm{Sc}, \mathrm{V}, \mathrm{Cr}, \mathrm{Ni}, \mathrm{Cu}$ and $\mathrm{Cs})$. The mean values determined for $\mathrm{V}$ and $\mathrm{Cu}$ are lower by $10-13 \%$ respectively, while $\mathrm{Cr}$ and Cs values are significantly lower by $\sim 20$ $30 \%$ respectively, and $\mathrm{Mg}$ is higher by $\sim 12 \%$ (Jochum et al., 2006). The mean values determined for Sc and Ni were substantially lower than the recommended values by $\sim 55$ $\%$ (Jochum et al., 2006). The day-to-day precision of LA-ICP-MS trace element concentrations is reflected in the repeated measurements of ATHO-G and was typically within $\pm 6-10 \%$ ( 2 sd relative) for the most significant elements used in the geochemical characterisation and correlation of the tephra layers ( $\mathrm{Li}, \mathrm{Mg}, \mathrm{Ca}, \mathrm{Ti}, \mathrm{Mn}, \mathrm{Cu}, \mathrm{Zn}, \mathrm{Rb}, \mathrm{Sr}, \mathrm{Y}$, $\mathrm{Zr}, \mathrm{Nb}, \mathrm{Ba}, \mathrm{La}, \mathrm{Ce}, \mathrm{Pr}, \mathrm{Nd}, \mathrm{Dy}, \mathrm{Ta}, \mathrm{Pb}$, Th and U). However, many other trace elements of interest (in particular the REE, V, Hf and W) have reproducibility within $\pm 11-15 \%$ (2 sd relative) and were nevertheless utilised in the geochemical characterisation and correlation of the tephra layers. The precision of the comparatively low concentration elements was more varied, B, Sc, Ni and Cs typically $16-32 \%$, and $\mathrm{Cr}$ approximately $80 \%$. These elements (with the exception of B) were rarely used in the geochemical characterisation and correlation of the tephra layers. 


\begin{tabular}{|c|c|c|c|c|c|}
\hline \multicolumn{6}{|c|}{ Rhyolitic Glass MPI-DING ATHO-G $(n=38)$} \\
\hline & $\begin{array}{c}\text { Jochum et al. } \\
\text { (2006) }\end{array}$ & Mean & $2 \mathrm{SD}$ & $\begin{array}{c}\text { Precision } \\
(\% 2 \mathrm{sd})\end{array}$ & $\begin{array}{l}\text { Accuracy } \\
\text { (\% diff.) }\end{array}$ \\
\hline${ }^{7} \mathrm{Li}$ & 28.6 & 31.1 & 2.09 & 6.7 & 8.8 \\
\hline${ }^{11} \mathrm{~B}$ & 5.70 & 5.82 & 1.39 & 23.9 & 2.2 \\
\hline${ }^{24} \mathrm{Mg}$ & 621 & 697 & 45.0 & 6.5 & 12.2 \\
\hline${ }^{29} \mathrm{Si}$ & 75.6 & 75.6 & 0.00 & 0.0 & 0.0 \\
\hline${ }^{43} \mathrm{Ca}$ & 1.70 & 1.73 & 0.11 & 6.4 & 2.0 \\
\hline${ }^{45} \mathrm{Sc}$ & 7.00 & 10.7 & 3.35 & 31.2 & 53.3 \\
\hline${ }^{47} \mathrm{Ti}$ & 1529 & 1636 & 103 & 6.3 & 7.0 \\
\hline${ }^{51} \mathrm{~V}$ & 3.91 & 3.50 & 0.38 & 10.9 & -10.4 \\
\hline${ }^{53} \mathrm{Cr}$ & 6.10 & 4.29 & 3.36 & 78.3 & -29.7 \\
\hline${ }^{55} \mathrm{Mn}$ & 821 & 804 & 41.3 & 5.1 & -2.1 \\
\hline${ }^{60} \mathrm{Ni}$ & 13.0 & 5.80 & 1.29 & 22.2 & -55.4 \\
\hline${ }^{63} \mathrm{Cu}$ & 18.6 & 16.2 & 1.40 & 8.6 & -12.8 \\
\hline${ }^{66} \mathrm{Zn}$ & 141 & 134 & 12.4 & 9.3 & -5.3 \\
\hline${ }^{85} \mathrm{Rb}$ & 65.3 & 62.5 & 2.40 & 3.8 & -4.3 \\
\hline${ }^{88} \mathrm{Sr}$ & 94.1 & 92.5 & 6.77 & 7.3 & -1.7 \\
\hline${ }^{89} \mathrm{Y}$ & 94.5 & 98.7 & 6.78 & 6.9 & 4.5 \\
\hline${ }^{90} \mathrm{Zr}$ & 512 & 541 & 51.7 & 9.5 & 5.7 \\
\hline${ }^{93} \mathrm{Nb}$ & 62.4 & 66.4 & 3.64 & 5.5 & 6.4 \\
\hline${ }^{133} \mathrm{Cs}$ & 1.08 & 0.87 & 0.15 & 16.8 & -19.9 \\
\hline${ }^{137} \mathrm{Ba}$ & 547 & 547 & 41.1 & 7.5 & 0.0 \\
\hline${ }^{139} \mathrm{La}$ & 55.6 & 56.8 & 4.56 & 8.0 & 2.1 \\
\hline${ }^{140} \mathrm{Ce}$ & 121 & 121 & 8.13 & 6.7 & 0.2 \\
\hline${ }^{14} 1 \operatorname{Pr}$ & 14.6 & 14.5 & 1.02 & 7.0 & -0.3 \\
\hline${ }^{146} \mathrm{Nd}$ & 60.9 & 63.5 & 4.80 & 7.6 & 4.3 \\
\hline${ }^{147} \mathrm{Sm}$ & 14.2 & 14.7 & 2.00 & 13.6 & 3.4 \\
\hline${ }^{153} \mathrm{Eu}$ & 2.76 & 2.69 & 0.29 & 10.9 & -2.5 \\
\hline${ }^{157} \mathrm{Gd}$ & 15.3 & 15.2 & 2.17 & 14.2 & -0.4 \\
\hline${ }^{159} \mathrm{~Tb}$ & 2.51 & 2.53 & 0.33 & 13.2 & 0.9 \\
\hline${ }^{163}$ Dy & 16.2 & 17.7 & 1.70 & 9.6 & 9.5 \\
\hline${ }^{165} \mathrm{Ho}$ & 3.43 & 3.65 & 0.40 & 11.0 & 6.5 \\
\hline${ }^{166} \mathrm{Er}$ & 10.3 & 11.0 & 1.38 & 12.6 & 6.6 \\
\hline${ }^{169} \mathrm{Tm}$ & 1.52 & 1.64 & 0.22 & 13.4 & 7.8 \\
\hline${ }^{172} \mathrm{Yb}$ & 10.5 & 10.9 & 1.25 & 11.5 & 4.0 \\
\hline${ }^{175} \mathrm{Lu}$ & 1.54 & 1.61 & 0.25 & 15.7 & 4.7 \\
\hline${ }^{178} \mathrm{Hf}$ & 13.7 & 14.0 & 1.64 & 11.7 & 2.2 \\
\hline${ }^{181} \mathrm{Ta}$ & 3.90 & 4.21 & 0.41 & 9.8 & 7.8 \\
\hline${ }^{182} \mathrm{~W}$ & 9.30 & 8.75 & 1.17 & 13.4 & -6.0 \\
\hline${ }^{208} \mathrm{~Pb}$ & 5.67 & 5.14 & 0.45 & 8.8 & -9.4 \\
\hline${ }^{232} \mathrm{Th}$ & 7.40 & 7.88 & 0.71 & 9.1 & 6.6 \\
\hline${ }^{238} \mathrm{U}$ & 2.37 & 2.25 & 0.21 & 9.3 & -4.9 \\
\hline $\mathrm{Rb} / \mathrm{Sr}$ & 0.69 & 0.68 & 0.06 & 8.5 & -2.5 \\
\hline $\mathrm{Zr} / \mathrm{Th}$ & 69.2 & 68.7 & 4.02 & 5.9 & -0.7 \\
\hline $\mathrm{Zr} / \mathrm{Y}$ & 5.42 & 5.48 & 0.24 & 4.3 & 1.2 \\
\hline $\mathrm{Y} / \mathrm{Th}$ & 12.8 & 12.5 & 0.88 & 7.0 & -1.9 \\
\hline $\mathrm{Rb} / \mathrm{Sm}$ & 4.60 & 4.28 & 0.62 & 14.5 & -6.9 \\
\hline $\mathrm{Eu} / \mathrm{Eu}^{*}$ & 0.57 & 0.55 & 0.06 & 10.3 & -3.7 \\
\hline
\end{tabular}

Table 2.5: LA-ICP-MS precision and accuracy for international rhyolitic glass standard ATHO-G measured in this study. Notes: values are calculated from daily repeated analyses $(\mathrm{n}=38)$. Jochum et al. (2006) preferred values, means and 2 standard errors are reported in parts per million ( $\mathrm{ppm})$. 


\subsubsection{The Use of Different Internal Standards}

Tests conducted in the early stages of LA-ICP-MS data acquisition during this study have shown that ${ }^{29} \mathrm{Si}$ appears to be a more effective internal standard than ${ }^{43} \mathrm{Ca}$ for secondary

data normalisation, and thus ${ }^{29} \mathrm{Si}$ was used as the internal standard for calculating all trace element abundances of the rhyolitic glasses analysed in this research. In order to demonstrate the validity of this statement, all analyses of the international rhyolitic glass standard ATHO-G have been normalised using both ${ }^{29} \mathrm{Si}$ and ${ }^{43} \mathrm{Ca}$ as an internal standard for secondary data normalisation (Figure 2.3 (A) and (B); Table 2.6).

EPMA characterisation of the homogeneous basaltic reference glass VG-A99 (Table 2.2) suggests that $\mathrm{SiO}_{2}$ can be measured with greater precision $( \pm 4.2 \%, 2$ sd relative $)$ compared to $\mathrm{CaO}( \pm 5.4 \%, 2$ sd relative $)$, making ${ }^{29} \mathrm{Si}$ more appealing for use as an internal standard in LA-ICP-MS. The higher natural abundance of ${ }^{29} \mathrm{Si}$ (4.67\% of all Si) compared to ${ }^{43} \mathrm{Ca}(0.135 \%$ of all $\mathrm{Ca})$ with respect to the high concentration of $\mathrm{SiO}_{2}(72.0-$ 78.0 wt. \%) and low concentration of $\mathrm{CaO}(0.7$ - 2.2 wt. \%) in $\mathrm{CVZ}$ rhyolitic glasses produces the need to consider saturation of the LA-ICP-MS detector by the internal standard isotope. Saturation of the LA-ICP-MS detector when employing ${ }^{29} \mathrm{Si}$ was monitored during data acquisition by measurement of pulse/analogue (P/A) factors. Observed values suggest that under the operating conditions used in this study 'pulse pile up' (detector saturation) was minimal (Longerich and Diegor, 2001). 

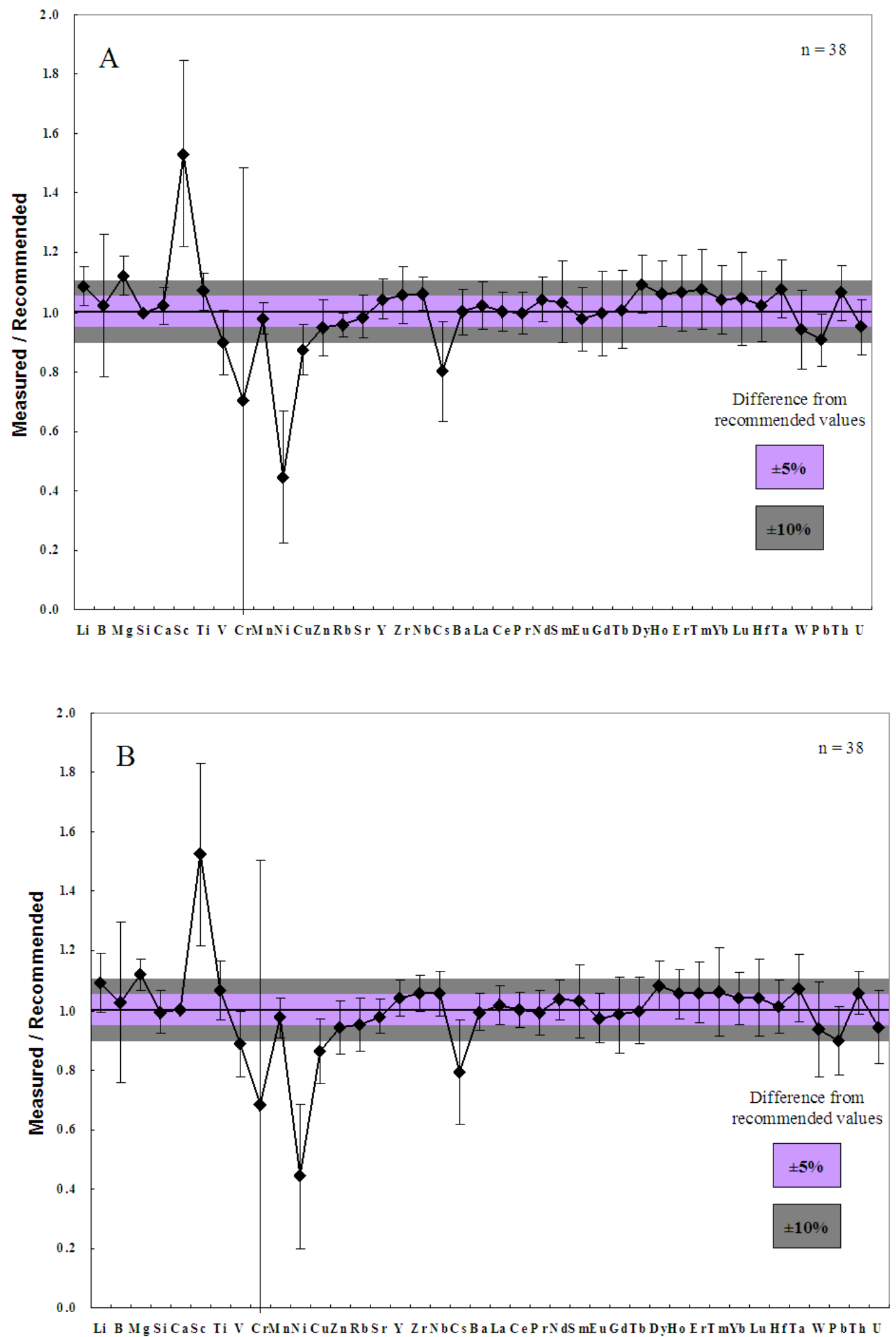

Fig. 2.3: Normalised trace element data for the international rhyolitic glass standard ATHO-G measured by LA-ICP-MS. The data represents the mean values $(n=38)$ normalised to the certified values of Jochum et al. (2006). A: ${ }^{29} \mathrm{Si}$ used as the internal standard isotope. Out of the 39 minor and trace elements analysed, nineteen are accurate to within $\pm 5 \%$ of the preferred reference values, and an additional thirteen agree to within $\pm 5-10 \%$ of the preferred reference values. B: ${ }^{43} \mathrm{Ca}$ used as the internal standard isotope for comparison to A. Note how identical these two figures appear. 
The need to make a correction for mass interfering species on the measured signal intensities for both ${ }^{29} \mathrm{Si}$ and ${ }^{43} \mathrm{Ca}$ (when either is utilised as an internal standard isotope) is preventable (e.g. oxide interference on ${ }^{29} \mathrm{Si},{ }^{13} \mathrm{~N}+{ }^{16} \mathrm{O}$ ). The LA-ICP-MS instrument was optimised for sensitivity and minimal molecular oxide production $\left(\mathrm{ThO}^{+} / \mathrm{Th}^{+}\right.$typically $<$ $1.5 \%)$ through optimisation of plasma torch conditions and, to a lesser extent, oven drying each sample preceding analysis (see above). Analysis of single glass shards requires optimal instrument sensitivity and low backgrounds to give the best signal-to-noise ratio (Pearce et al., 2008). A signal-to-noise ratio compares the level of a desired signal to the level of background noise. The higher the ratio, the less significant the background noise. ${ }^{29} \mathrm{Si}$ produced a superior signal to noise ratio (60 - 70) compared to ${ }^{43} \mathrm{Ca}(3-4)$ making ${ }^{29} \mathrm{Si}$ more appealing for use as an internal standard in LA-ICP-MS analysis of rhyolitic glass shards.

One can determine the effective use of an internal standard for secondary data normalisation in LA-ICP-MS analyses based on the four aspects outlined above: (1) precisely measured concentration of the internal standard by EPMA; (2) selection of a low abundance isotope of the internal standard to minimise problems associated with detector saturation; (3) mass interferences on the internal standard isotope should be negligible; and (4) the internal standard isotope must have a low signal-to-noise ratio.

By making relative comparisons between the precision and accuracy data obtained for the international rhyolitic glass standard ATHO-G when ${ }^{29} \mathrm{Si}$ and ${ }^{43} \mathrm{Ca}$ are utilised as the internal standard isotope it is possible to ascertain that, in some instances, ${ }^{29} \mathrm{Si}$ and ${ }^{43} \mathrm{Ca}$ are equally effective. Furthermore, either ${ }^{29} \mathrm{Si}$ or ${ }^{43} \mathrm{Ca}$ can become the preferred choice of internal standard isotope for secondary data normalisation for an isotope of a particular trace element (Table 2.6). For example, it is apparent that ${ }^{29} \mathrm{Si}$ is a more effective internal standard when used to normalise the relatively low concentration elements (e.g. V, Cr and $\mathrm{Cs})$, whereas ${ }^{43} \mathrm{Ca}$ is a more effective internal standard when used to normalise the majority of the rare earth elements. In future studies it is recommended that both ${ }^{29} \mathrm{Si}$ and ${ }^{43} \mathrm{Ca}$ be utilised simultaneously in order to produce a series of trace element data that ensures both precision and accuracy have been maximised. 


\begin{tabular}{|c|c|c|c|c|c|}
\hline \multicolumn{6}{|c|}{ Rhyolitic Glass MPI-DING ATHO-G } \\
\hline & \multicolumn{2}{|c|}{${ }^{29} \mathrm{Si}(\mathrm{n}=38)$} & \multicolumn{2}{|c|}{${ }^{43} \mathrm{Ca}(\mathrm{n}=38)$} & \\
\hline & Precision & Accuracy & Precision & Accuracy & Recommended \\
\hline${ }^{7} \mathrm{Li}$ & 6.7 & 8.8 & 10.0 & 9.1 & ${ }^{29} \mathrm{Si}$ \\
\hline${ }^{11} \mathrm{~B}$ & 23.9 & 2.2 & 27.1 & 2.8 & ${ }^{29} \mathrm{Si}$ \\
\hline${ }^{24} \mathrm{Mg}$ & 6.5 & 12.2 & 5.3 & 12.1 & ${ }^{43} \mathrm{Ca}$ \\
\hline${ }^{29} \mathrm{Si}$ & 0.0 & 0.0 & 7.2 & -0.5 & - \\
\hline${ }^{43} \mathrm{Ca}$ & 6.4 & 2.0 & 0.0 & 0.0 & - \\
\hline${ }^{45} \mathrm{Sc}$ & 31.2 & 53.3 & 30.7 & 52.5 & ${ }^{43} \mathrm{Ca}$ \\
\hline${ }^{47} \mathrm{Ti}$ & 6.3 & 7.0 & 10.1 & 6.6 & ${ }^{29} \mathrm{Si}$ \\
\hline${ }^{51} \mathrm{~V}$ & 10.9 & -10.4 & 10.9 & -11.1 & ${ }^{29} \mathrm{Si}$ \\
\hline${ }^{53} \mathrm{Cr}$ & 78.3 & -29.7 & 81.9 & -31.5 & ${ }^{29} \mathrm{Si}$ \\
\hline${ }^{55} \mathrm{Mn}$ & 5.1 & -2.1 & 6.6 & -2.4 & ${ }^{29} \mathrm{Si}$ \\
\hline${ }^{60} \mathrm{Ni}$ & 22.2 & -55.4 & 24.1 & -55.8 & ${ }^{29} \mathrm{Si}$ \\
\hline${ }^{63} \mathrm{Cu}$ & 8.6 & -12.8 & 11.0 & -13.7 & ${ }^{29} \mathrm{Si}$ \\
\hline${ }^{66} \mathrm{Zn}$ & 9.3 & -5.3 & 9.2 & -5.8 & ${ }^{29} \mathrm{Si}$ \\
\hline${ }^{85} \mathrm{Rb}$ & 3.8 & -4.3 & 8.9 & -4.8 & ${ }^{29} \mathrm{Si}$ \\
\hline${ }^{88} \mathrm{Sr}$ & 7.3 & -1.7 & 5.6 & -2.0 & ${ }^{29} \mathrm{Si}$ \\
\hline${ }^{89} \mathrm{Y}$ & 6.9 & 4.5 & 6.1 & 4.2 & ${ }^{43} \mathrm{Ca}$ \\
\hline${ }^{90} \mathrm{Zr}$ & 9.5 & 5.7 & 6.0 & 5.5 & ${ }^{43} \mathrm{Ca}$ \\
\hline${ }^{93} \mathrm{Nb}$ & 5.5 & 6.4 & 7.4 & 5.9 & ${ }^{43} \mathrm{Ca}$ \\
\hline${ }^{133} \mathrm{Cs}$ & 16.8 & -19.9 & 17.5 & -20.6 & ${ }^{29} \mathrm{Si}$ \\
\hline${ }^{137} \mathrm{Ba}$ & 7.5 & 0.0 & 6.4 & -0.6 & ${ }^{29} \mathrm{Si}$ \\
\hline${ }^{139} \mathrm{La}$ & 8.0 & 2.1 & 6.7 & 1.7 & ${ }^{43} \mathrm{Ca}$ \\
\hline${ }^{140} \mathrm{Ce}$ & 6.7 & 0.2 & 6.0 & 0.1 & ${ }^{43} \mathrm{Ca}$ \\
\hline${ }^{14} 1 \mathrm{Pr}$ & 7.0 & -0.3 & 7.5 & -0.8 & ${ }^{29} \mathrm{Si}$ \\
\hline${ }^{146} \mathrm{Nd}$ & 7.6 & 4.3 & 6.8 & 3.5 & ${ }^{43} \mathrm{Ca}$ \\
\hline${ }^{147} \mathrm{Sm}$ & 13.6 & 3.4 & 12.1 & 3.1 & ${ }^{43} \mathrm{Ca}$ \\
\hline${ }^{153} \mathrm{Eu}$ & 10.9 & -2.5 & 8.2 & -2.6 & ${ }^{43} \mathrm{Ca}$ \\
\hline${ }^{157} \mathrm{Gd}$ & 14.2 & -0.4 & 12.7 & -1.5 & ${ }^{29} \mathrm{Si}$ \\
\hline${ }^{159} \mathrm{~Tb}$ & 13.2 & 0.9 & 11.1 & -0.0 & ${ }^{43} \mathrm{Ca}$ \\
\hline${ }^{163}$ Dy & 9.6 & 9.5 & 8.3 & 8.5 & ${ }^{43} \mathrm{Ca}$ \\
\hline $165 \mathrm{Ho}$ & 11.0 & 6.5 & 8.3 & 5.5 & ${ }^{43} \mathrm{Ca}$ \\
\hline${ }^{166} \mathrm{Er}$ & 12.6 & 6.6 & 10.2 & 5.8 & ${ }^{43} \mathrm{Ca}$ \\
\hline${ }^{169} \mathrm{Tm}$ & 13.4 & 7.8 & 15.0 & 6.5 & ${ }^{43} \mathrm{Ca}$ \\
\hline${ }^{172} \mathrm{Yb}$ & 11.5 & 4.0 & 8.7 & 4.2 & ${ }^{43} \mathrm{Ca}$ \\
\hline${ }^{175} \mathrm{Lu}$ & 15.7 & 4.7 & 13.1 & 4.3 & ${ }^{43} \mathrm{Ca}$ \\
\hline${ }^{178} \mathrm{Hf}$ & 11.7 & 2.2 & 9.1 & 1.3 & ${ }^{43} \mathrm{Ca}$ \\
\hline${ }^{181} \mathrm{Ta}$ & 9.8 & 7.8 & 11.3 & 7.4 & ${ }^{43} \mathrm{Ca}$ \\
\hline${ }^{182} \mathrm{~W}$ & 13.4 & -6.0 & 15.8 & -6.2 & ${ }^{29} \mathrm{Si}$ \\
\hline${ }^{208} \mathrm{~Pb}$ & 8.8 & -9.4 & 11.4 & -10.1 & ${ }^{29} \mathrm{Si}$ \\
\hline${ }^{232} \mathrm{Th}$ & 9.1 & 6.6 & 7.2 & 6.0 & ${ }^{43} \mathrm{Ca}$ \\
\hline${ }^{238} \mathrm{U}$ & 9.3 & -4.9 & 12.1 & -5.6 & ${ }^{29} \mathrm{Si}$ \\
\hline
\end{tabular}

Table 2.6: Comparison of the precision and accuracy for international rhyolitic glass standard ATHO-G analysed by LA-ICP-MS in this study, when both ${ }^{29} \mathrm{Si}$ and ${ }^{43} \mathrm{Ca}$ are utilised as the internal standard isotope. The column titled 'recommended' suggests the preferred choice of internal standard isotope $\left({ }^{29} \mathrm{Si}\right.$ or $\left.{ }^{43} \mathrm{Ca}\right)$ for secondary data normalisation for an isotope of a particular trace element analysed in this study. The 'recommended' choice is based on a relative comparison between the precision and accuracy offered by both internal standard isotopes. Note: values are calculated from daily repeated analyses (n $=38$ ) and reported in parts per million ( $\mathrm{ppm})$. 


\subsubsection{Existing Trace Element Data for Miocene-Pliocene Coromandel Volcanic Zone Tephras}

At the time of submission only one published study (Shane et al., 1998), has applied the LA-ICP-MS technique to the acquisition of trace element concentrations from single shards of volcanic glass sourced from the CVZ. Shane et al. (1998) sampled a number of 7 - 9 Myr old tephra beds deposited in rapidly accumulating turbidite and hemipelagic marine sequences within forearc basins and slope-trench settings now uplifted and exposed along the East Coast of New Zealand's North Island. An ArF 193 nm Excimer laser was utilised for trace element analysis. Instrument calibration was against NIST 612 glass $(\mathrm{n}=$ 1), employing ${ }^{43} \mathrm{Ca}$ as the internal standard isotope based on $\mathrm{CaO}$ concentrations measured in the glass by EPMA. Data reproducibility was monitored by analysis of the USGS secondary glass standard BCR-2G $(\mathrm{n}=3)$. BCR-2G $\left(\mathrm{SiO}_{2}=54.4\right.$ wt. \% $)$ is considered a poor choice of reference glass, as it does not represent a close matrix match to the ablated material from $\mathrm{CVZ}$ samples $\left(\mathrm{SiO}_{2}=72.0-78.0\right.$ wt. \%) (e.g. Allan, 2008). A poor choice of calibration standard may generate differential elemental fractionation (matrix effects) during analysis between the standard and sample producing inaccurate data (Eggins et al., 1998; Pearce et al., 2008). 


\subsection{Results - Composition of the Silicic Tephras}

The application of microanalytical techniques to the geochemical characterisation of tephras have become widely used with promising results worldwide and in New Zealand (e.g. Smith \& Westgate, 1969; Howorth \& Rankin, 1975; Froggatt, 1983; Ledbetter, 1985; Westgate et al., 1994; Shane et al., 1998; Bryant et al., 1999; Pearce et al., 1999; Carter et al., 2003, 2004; Harangi et al., 2005; Pearce et al., 2007; Allan et al., 2008). Individual glass shard compositions have greatly enhanced identification of subtle geochemical differences between tephras, and to provide insights on the mechanisms of magma generation.

EPMA and LA-ICP-MS permit the discrimination of individual glass shards and avoidance of contamination and chemical alteration problems. Therefore, glass shards from each of the 72 tephras were analysed by EPMA and LA-ICP-MS, to (i) determine the composition of the source magmas, (ii) elucidate the mechanisms of magma generation, and (iii) verify the use of glass chemistry as a means of characterising individual tephras.

\subsection{Major Element Geochemistry}

As a consequence of the rigorous approach during EPMA (see Section 2.3), a good level of confidence can be had regarding the quality of the data collected (Appendix Two). However, the data set could be further improved by the additional determination of minor elements (e.g. P, S) and volatiles (e.g. F). A minimum of eighteen glass shards from each tephra layer was selected for analysis (based on shard size and purity) anticipating the presence of sample heterogeneity or bimodality. However, single glass shards in many of the samples were unable to accommodate the spot size employed for analysis due to their very-fine grainsize permitting fewer analyses for some tephras than planned. 
The mean major element compositions of individual glass shards from each tephra layer are presented (Appendix Two). Where multiple geochemical glass shard populations were identified in a single tephra layer, a separate mean has been calculated and attributed to each population. All major element data have been normalised to $100 \mathrm{wt}$ \% on an anhydrous basis. Analytical totals for individual glass shards were typically 91.0 - 99.0 wt. \% indicating the presence of volatiles in the glass. Individual analyses that totalled < 91.0 wt. \% were discarded. Two exceptions, samples M-65 (1124C-17X1, $110 \mathrm{~cm})$ and M-66 (1124C-17X5, $13.5 \mathrm{~cm})$, were very hydrated, returning analytical totals for all shards ranging from 90.0 - 92.5 wt. \% and 89.5 - 95.0 wt. \% (seven shards between 89.5 - 90.5 wt. \%) respectively. It is possible some of the low analytical major element totals are associated with the loss of $\mathrm{Na}$ and $\mathrm{K}$ during electron beam bombardment, although this loss should be minimal due to the defocused beam diameter employed and $\mathrm{Na}$ and $\mathrm{K}$ were run first. Low analytical major element totals can also arise from a primary magmatic (original) volatile signature or as a result of subsequent alteration-induced volatile hydration. Distinguishing between these two possibilities, in the absence of alterationrelated hydration, can be difficult.

Additionally, the major element compositional fields for Quaternary TVZ tephra layers from ODP Site 1123 (Figure 1.1) (Allan, 2008; Allan et al., 2008) are included on all the variation diagrams (below) for the purpose of better understanding the transition from the generation of large volumes of rhyolitic magma in the CVZ to the TVZ.

\subsubsection{Classification of Site 1124 Tephra Layers}

Site 1124-C glasses display predominantly rhyolitic (> 70.0 wt. $\% \mathrm{SiO}_{2}$ ) chemical compositions and plot mostly within the corresponding field on a total alkali-silica (TAS) discrimination diagram (Figure 3.1). An exception is sample M-46 (1124C-13H5, $72 \mathrm{~cm})$, which included glasses of andesitic $(n=6)$, dacitic $(n=6)$ and rhyolitic $(n=4)$ chemical composition. One other sample (M-14 - 1124C-9H5, $40 \mathrm{~cm}$ ) has a marginally dacitic (69.9 wt. \% $\mathrm{SiO}_{2}$ ) composition that falls on the boundary between dacite and rhyolite (Figure 3.1). For the most part, the rhyolitic glasses show a positive correlation between $\mathrm{K}_{2} \mathrm{O}$ and $\mathrm{SiO}_{2}$ (Figure 3.2), plotting principally in the medium-K classification field typical of arc rhyolites. Some samples (M-49, M-50, M-52, M-59) exhibit high-K affinities extending above both CVZ and TVZ rhyolite data fields. The source magmas of the tephra layers had chemistry typical of calc-alkaline to high-K calc-alkaline suite rocks (Figure 
3.2). Onshore whole-rock geochemical analysis of CVZ ignimbrites and rhyolitic lava flows report calc-alkaline to high-K calc-alkaline rock suites (Adams et al., 1994). Figures 3.1 and 3.2 validate the Carter et al. $(2003 ; 2004)$ geochemical evaluation of many of the Miocene to Pliocene tephra layers previously analysed from Site 1124. Trace amounts of andesitic and dacitic glass shards (typically no more than two) were found in many of the more silicic tephras. These relict andesitic and dacitic shards are not integrated into the calculation of the mean chemical compositions presented here. They do, however, represent syn-and-post-eruption chemical mixing of the products of different magmas (discussed later in Section 4.1). The majority of glass shards within individual tephra layers have narrow compositional ranges (plotting in relatively discrete groups) and based on EPMA data alone would be considered homogeneous. Several tephras display a pronounced bimodality in their chemical composition (Appendix Two). Implications of intra-tephra variation will be further discussed in association with representative major and trace element data in Section 4.1.

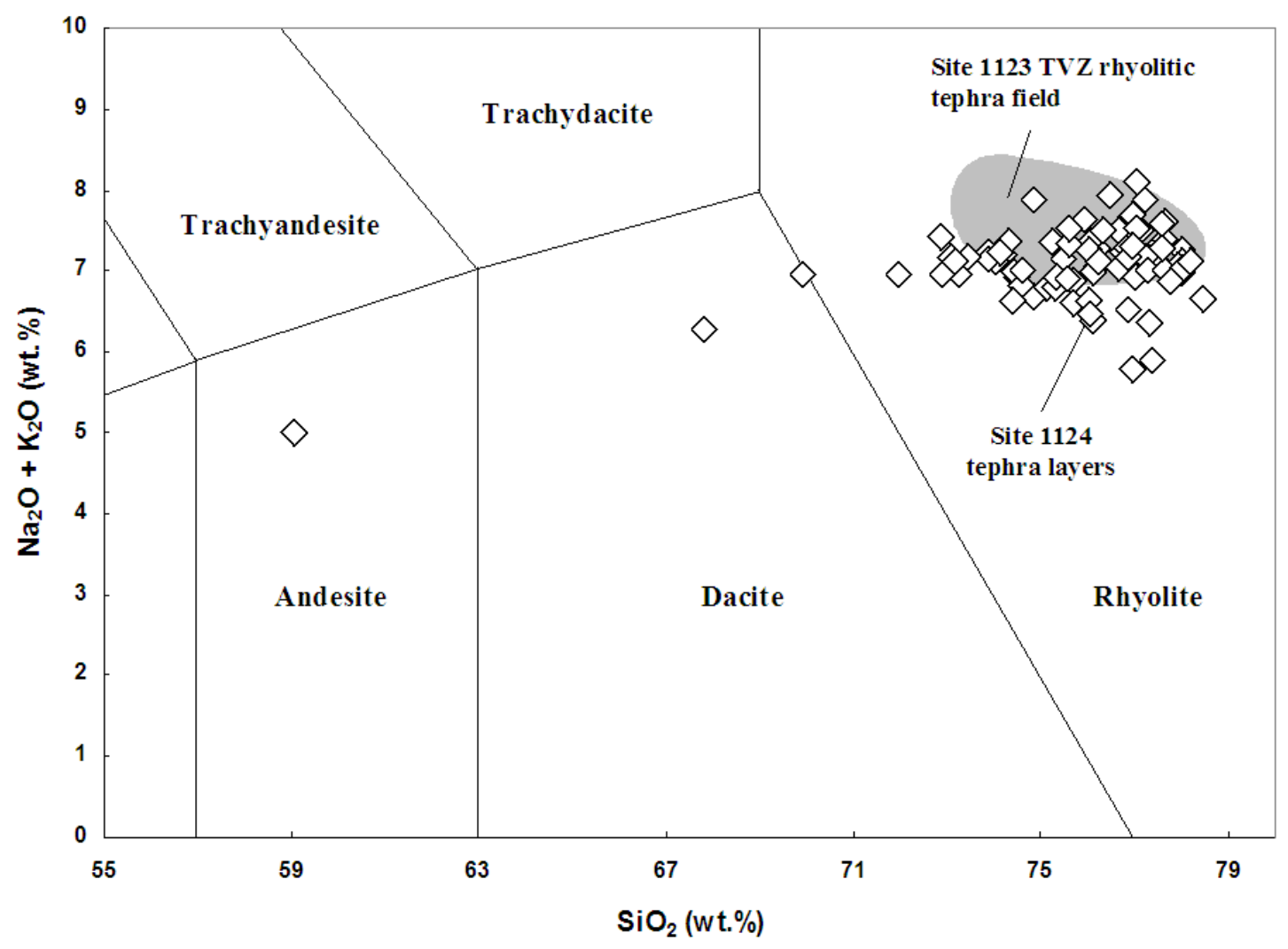

Fig. 3.1: Total alkalis $\left(\mathrm{Na}_{2} \mathrm{O}+\mathrm{K}_{2} \mathrm{O}\right)$ versus silica $\left(\mathrm{SiO}_{2}\right)$ discrimination diagram displaying the mean chemical compositions of Site 1124 tephras. The tephra layers analysed here fall predominantly within the rhyolite field using the classification scheme of Le Bas et al. (1986), see text for exceptions. ODP Site 1123 Quaternary TVZ rhyolite tephra field (grey) is from Allan et al. (2008). 


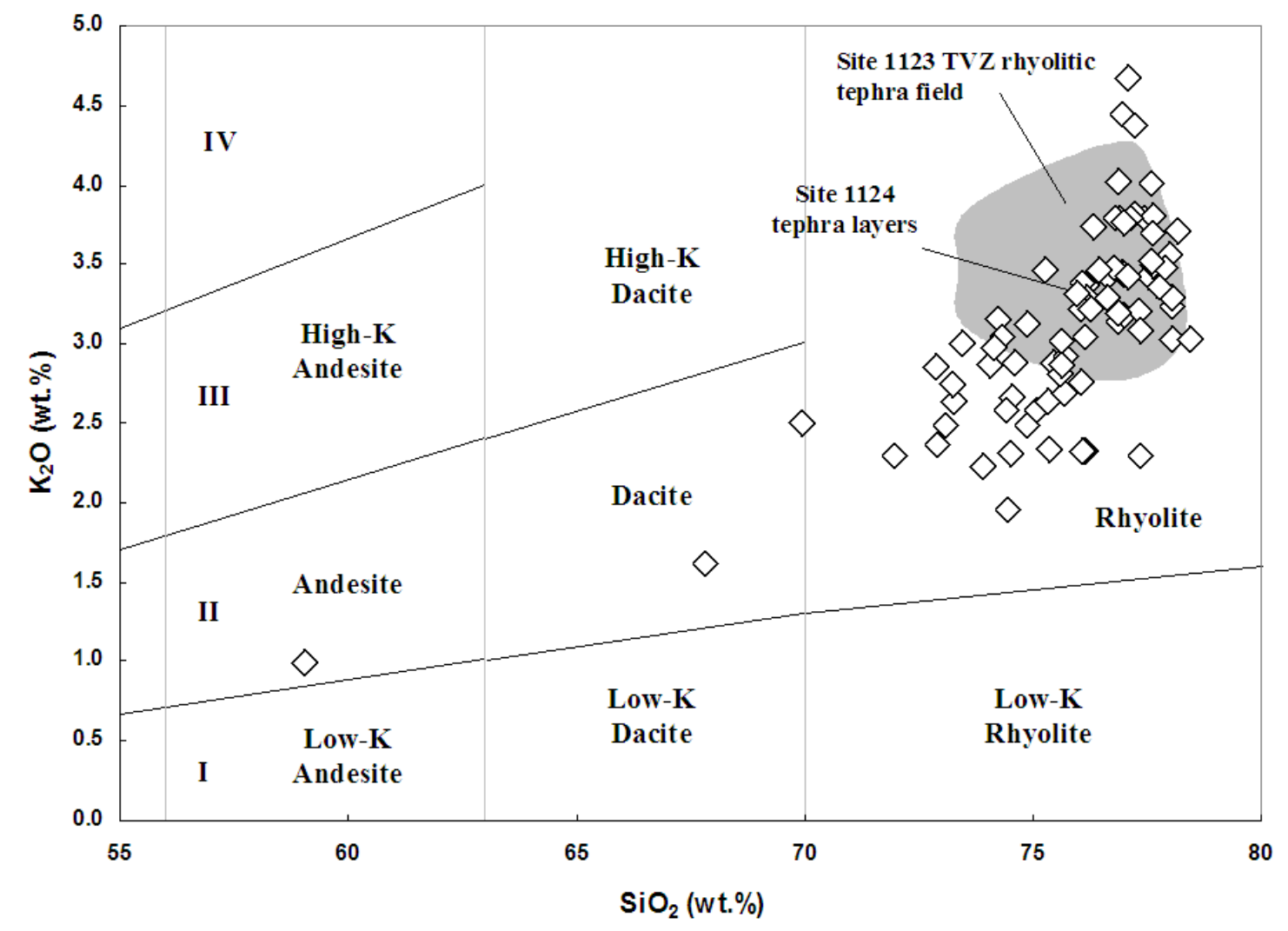

Fig. 3.2: Relationship between average $\mathrm{K}_{2} \mathrm{O}$ and $\mathrm{SiO}_{2}$ content of the predominantly rhyolitic Site 1124 tephras. The tephra layers analysed here fall across both the medium-K and high-K divisions using the classification scheme of Peccerillo and Taylor (1976). Divisions mark the boundaries between: arc tholeiite series (I), calc-alkaline series (II), high-K calc-alkaline series (III) and shoshonite series (IV). ODP Site 1123 Quaternary TVZ rhyolite tephra field (grey) is from Allan (2008).

\subsubsection{Temporal Changes and Glass Composition}

Figure 3.3 shows the mean temporal variability in $\mathrm{SiO}_{2}, \mathrm{~K}_{2} \mathrm{O}, \mathrm{FeO}, \mathrm{CaO}, \mathrm{MgO}$ and $\mathrm{Cl}$ concentrations of the Site 1124 tephras from $10 \mathrm{Ma}$ to $2 \mathrm{Ma}$. The andesitic component of sample M-46 (1124C-13H5, $72 \mathrm{~cm}$ ) was selectively removed from several of the major element profiles shown $\left(\mathrm{SiO}_{2}, \mathrm{FeO}, \mathrm{CaO}, \mathrm{MgO}\right)$ to enable a clearer view of the changing major element chemistry through time. The tephra profiles demonstrate a broad coherent variability throughout the history of the CVZ. The relative consistancy in major element oxide concentrations throughout time reveals the influence of steady-state processes as an important component in the generation of CVZ magmas. The degree of steady-state differentiation of the source magmas is reflected in the ranges of each major element oxide: $\mathrm{SiO}_{2}$ concentrations show a range in values from 71.0 - $78.0 \mathrm{wt}$ \% prior to $3.9 \mathrm{Ma}$; thereafter generally only high silica rhyolites (> $75.0 \mathrm{wt}$ \%) (excluding the borderline dacitic sample at $3.34 \mathrm{Ma}$ ) were erupted until the transition into the TVZ. Variations and 
values of the other major element oxides in the more silicic samples are not so marked (except $\mathrm{K}_{2} \mathrm{O}$ ), reflecting the compatible nature of these elements in the crystallographic structure of minerals in the differentiating magmas. Selected major element data illustrate these trends in Figure 3.4. Compatible $\mathrm{MgO}$ and $\mathrm{FeO}$ display positive covariation when plotted together (Figure $3.4 \mathrm{a}$ and c), other compatible major oxides (e.g. $\mathrm{CaO}$ ) have negative linear trends with respect to $\mathrm{SiO}_{2}$ (Figure $3.4 \mathrm{~b}$ and d), whereas relatively incompatible $\mathrm{K}_{2} \mathrm{O}$ is the only major element oxide that correlates positively with $\mathrm{SiO}_{2}$ (Figure 3.2). $\mathrm{Na}_{2} \mathrm{O}$ behaviour is two-fold (Figure 3.5), performing incompatibly in the andesitic and dacitic shards, subsequently becoming compatible (likely in a plagioclase phase) when the corresponding $\mathrm{SiO}_{2}$ abundance reaches rhyolitic values (> 70.0 wt. \%). Major element trends are linear, becoming clustered at the more silicic compositions.

These trends can be interpreted at a first-order level to reflect evolution from more primitive to more differentiated magmas. This more or less implicitly assumes a broad control by fractional crystallisation. The profile of trends can infer the nature of crystallising phases, for example, decreasing $\mathrm{FeO}$ and $\mathrm{MgO}$ (Figure 3.4 a and c) requires crystallisation of mafic minerals. The major element glass shard compositions are interpreted to represent single magma batches that have experienced variable fractionation; inferences on cogenetic parental magmas cannot be inferred. The more felsic (evolved) compositions may reflect longer residence time in the magmatic plumbing system, whereas the more primitive compositions reflect shorter residence times and are likely to represent the less silicic melts, which replenished the magmatic plumbing system subsequent to a major explosive eruption. Major element concentrations in glass shards provide a broad indication that fractional crystallisation processes were important in controlling geochemical variations in CVZ magmas. 


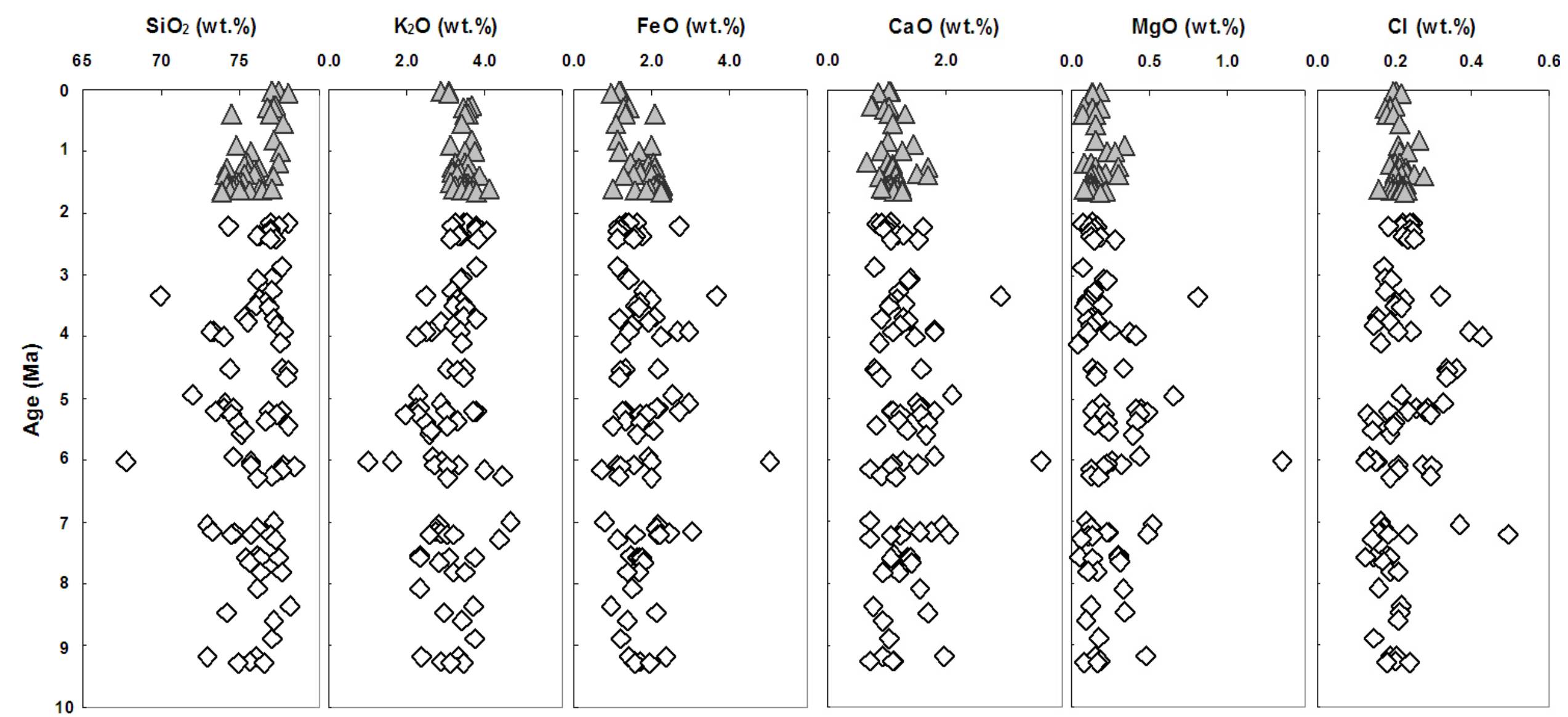

Fig. 3.3: The temporal evolution in major element chemistry of tephras from Site 1124-C (white diamonds) from 10 Ma to 2 Ma. Note the variability but long-term constancy in the major element profiles throughout most of the history of the CVZ. The andesitic component of sample M-46 (1124C-13H5, 72 $\mathrm{cm})$ was selectively removed from several of the major element profiles shown $\left(\mathrm{SiO}_{2}, \mathrm{FeO}, \mathrm{CaO}, \mathrm{MgO}\right)$. ODP Site 1123 Quaternary TVZ rhyolite tephras (grey triangles) is from Allan (2008). Each symbol represents the mean chemical composition of an individual eruptive unit. 

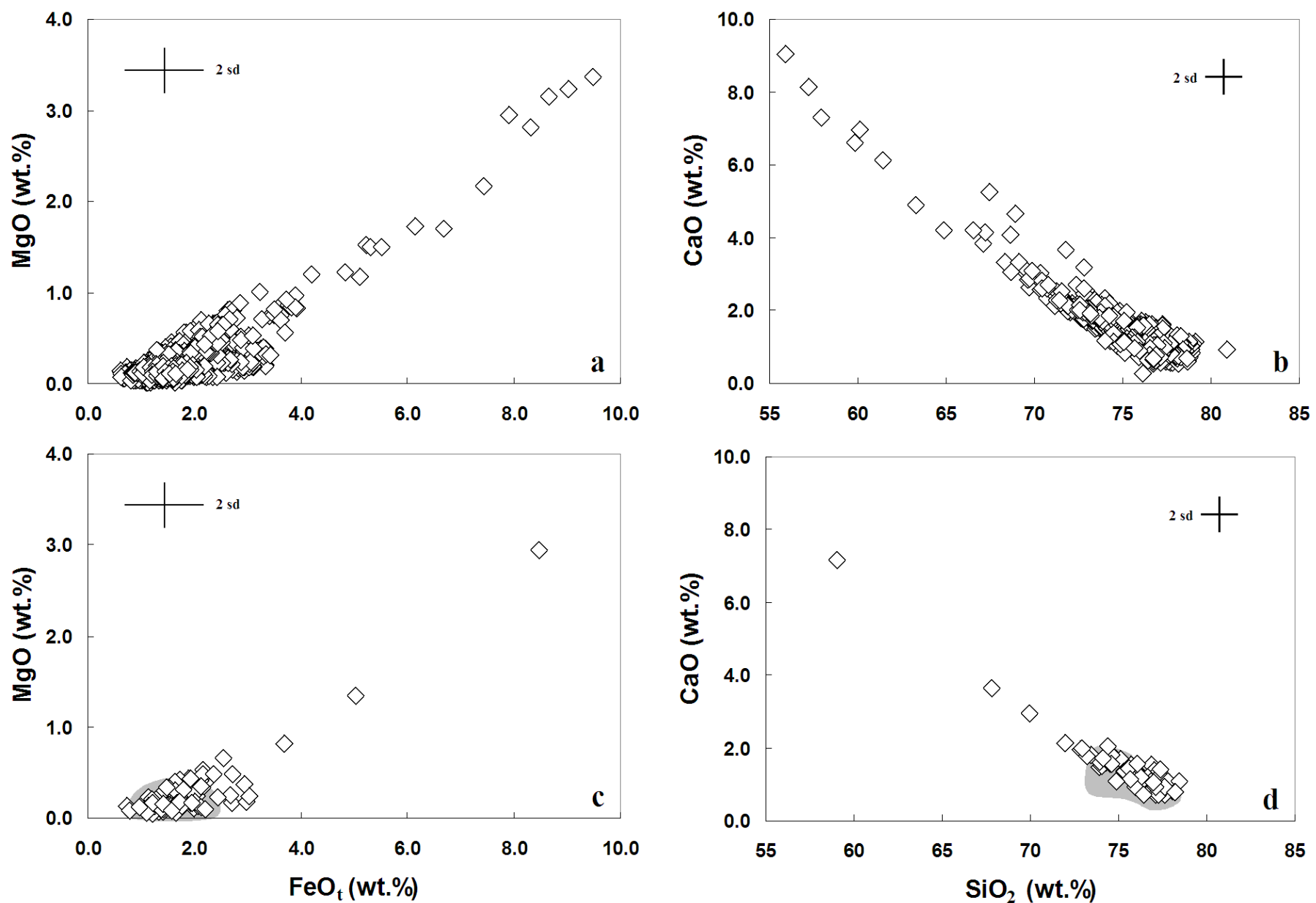

Fig. 3.4: Selected major element data for Site 1124-C tephra layers. For plots (a) and (b) each white diamond represents the composition of an individual glass shard analysis by EPMA. For plots (c) and (d) each white diamond represents the mean chemical composition of each tephra layer. ODP Site 1123 Quaternary TVZ rhyolite tephra field (grey) is from Allan (2008). (a) $\mathrm{MgO}$ versus $\mathrm{FeO}_{\mathrm{t}}$ (wt. \%), (b) $\mathrm{CaO}$ versus $\mathrm{SiO}_{2}$ (wt. \%), (c) mean $\mathrm{MgO}$ versus FeO (wt. \%), (d) mean $\mathrm{CaO}$ versus $\mathrm{SiO}_{2}$ (wt. \%). 


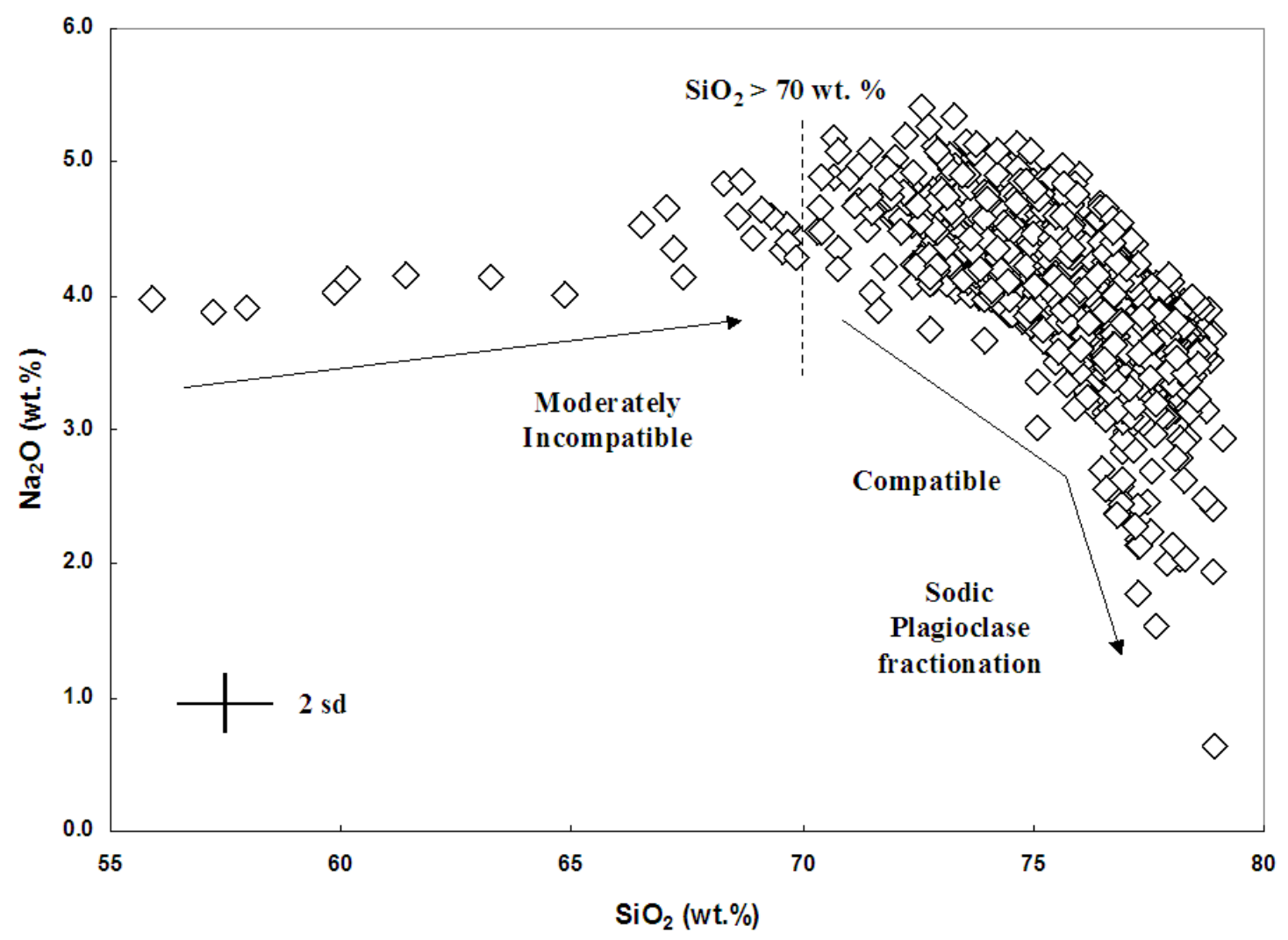

Fig. 3.5: Relationship between $\mathrm{Na}_{2} \mathrm{O}$ and $\mathrm{SiO}_{2}$ from individual glass shard compositions. Note the changing character of $\mathrm{Na}_{2} \mathrm{O}$, behaving incompatibly in the andesitic and dacitic shards $\left(<70.0\right.$ wt. \%), becoming compatible when $\mathrm{SiO}_{2}$ reaches rhyolitic values $(>70.0$ wt. \%). 


\subsection{Trace Element Geochemistry}

The mean trace element compositions of individual glass shards from each tephra layer are presented in Appendix Three. A minimum of eighteen glass shards from each tephra layer were selected for analysis anticipating sample heterogeneity or bimodality may be present. Trace element characterisation for every glass shard analysed by EPMA was not achievable due to plucking of some glass shards during cleaning of the mounts in preparation for trace element analysis by LA-ICP-MS (see Section 2.4). Occasional complications arose during analysis, such as shattering of glass shards observed during laser ablation, and the penetration of compositional boundaries during ablation that could not be foreseen, but were later recognised when examining the time-resolved data. As a result, trace element data were acquired for fewer shards for a particular sample compared to the equivalent major element data.

In some cases, rather than using the absolute concentrations of particular trace elements, trace element ratios are employed to monitor elemental enrichment and/or depletion relative to other trace elements, providing ratios independent of the absolute concentration.

Following Section 3.1, the trace element compositional fields for Quaternary TVZ tephra layers from ODP Site 1123 (Figure 1.1) (Allan, 2008; Allan et al., 2008) are included on all the variation diagrams (below) for the purpose of better understanding the transition from the generation of large volumes of rhyolitic magma in the CVZ to TVZ. 


\subsubsection{High Field Strength Elements (HFSE) and Rare Earth Elements (REE)}

The relationship between high field strength elements (HFSE) and REEs is assessed in Figure 3.6. A measure of relative light REE (LREE) to heavy REE (HREE) enrichment (e.g. $\mathrm{La} / \mathrm{Yb}$ ) and a guide to the degree of incompatible element depletion in the HFSEs (e.g. $\mathrm{Nb} / \mathrm{Zr}$ ) is employed. At a first-order level there is moderate positive covariation in the $\mathrm{Nb} / \mathrm{Zr}$ and $\mathrm{La} / \mathrm{Yb}$ ratios for mean glass shard compositions indicating that these elemental groups are coupled during petrogenesis. In the Site 1124-C tephras, low $\mathrm{Nb} / \mathrm{Zr}$ values generally correspond to low $\mathrm{La} / \mathrm{Yb}$ values, suggesting that no distinct common control on arc petrogenesis is present in the coupling of HFSEs and REEs. Higher La/Yb ratios can be explained by the presence of a residual garnet phase in the magma source (HREE have a high partition coefficient for this mineral). Alternatively, the introduction of fluid or crustal contamination may influence the $\mathrm{La} / \mathrm{Yb}$ ratio.

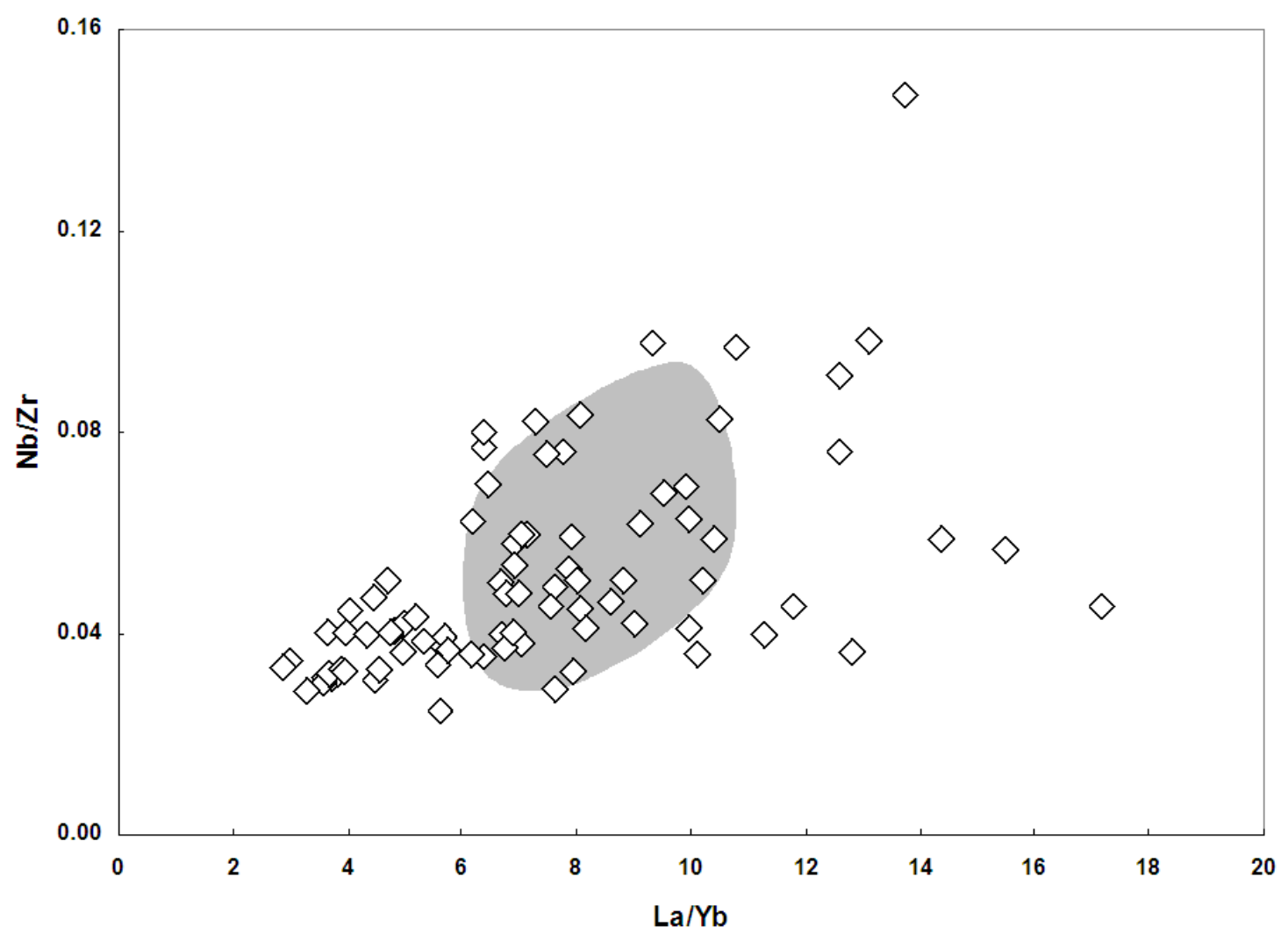

Fig. 3.6: Plot of $\mathrm{Nb} / \mathrm{Zr}$ versus $\mathrm{La} / \mathrm{Yb}$ showing moderate positive co-variation between high field strength elements $(\mathrm{Nb} / \mathrm{Zr})$ and rare earth elements $(\mathrm{La} / \mathrm{Yb})$ in mean glass shard compositions. This suggests that these elemental groups are partially coupled during petrogenesis. The grey field is from Allan (2008) highlighting the ODP Site 1123 Quaternary TVZ rhyolite tephra field. 


\subsubsection{Rare Earth Element diagrams}

CI chondrite-normalised trace element plots (values from Palme and Beer, 1993) are characterised by features distinctive of subduction-related magmas. The REE concentrations are normalised against CI chondrite in order to smooth out the differences in concentration between one element and another. Sample M-5 values for Eu and Tm have been selectively removed from Figure 3.7 due to erroneously low abundances.

Enrichment relative to $\mathrm{CI}$ chondrite represents a higher degree of magma differentiation. Chondrite-normalised REE values are plotted with the REEs arranged on the x-axis from the lightest to the heaviest (Figure 3.7). Relative to CI chondrite, all tephras display LREE over HREE enrichment with a weak to prominent negative Eu anomaly and a relatively flat HREE pattern slightly rising from Gd to Lu (Figure 3.7).

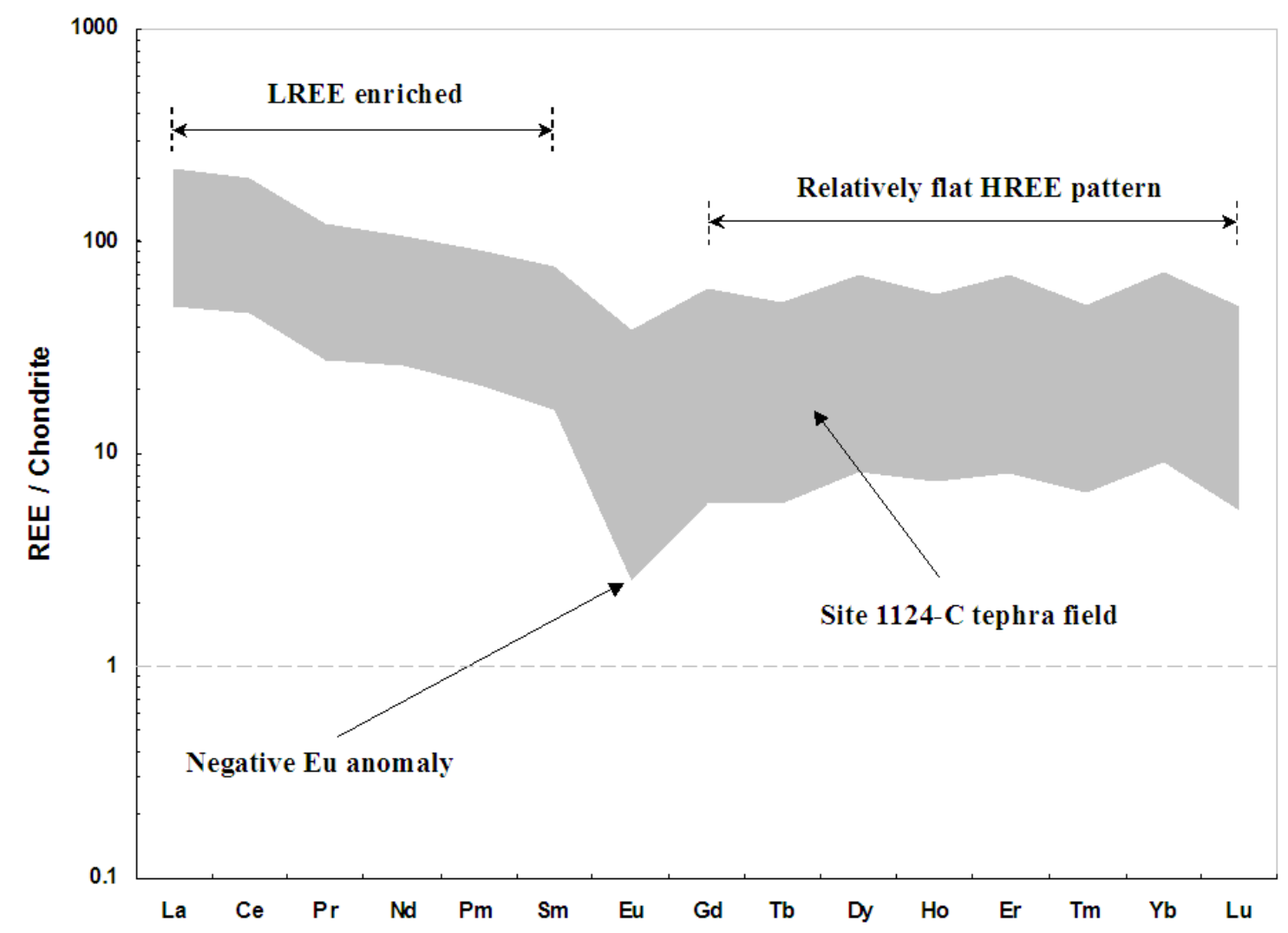

Fig. 3.7: Chondrite-normalised REE diagram for Site 1124-C tephras. CI chondrite values taken from Palme and Beer (1993). 


\subsubsection{Normalised Multi-element Diagrams}

Spider diagrams plot various trace elements regarded as being compatible or incompatible in respect to primitive or primordial mantle composition. Figure 3.8 demonstrates the range in values exhibited by Site 1124-C tephras normalised to primitive mantle values of Sun and McDonough (1989); plotted to reflect increasing compatibility in mantle phases. Sample M-5 value for Eu has been selectively removed from Figure 3.8 due to an erroneously low abundance. Using the element $\mathrm{Nb}$ as the reference point, large ion lithophile elements (LILE) (water-mobile elements), which include $\mathrm{Cs}, \mathrm{K}, \mathrm{Rb}, \mathrm{Sr}$, and $\mathrm{Ba}$, are placed on the left of $\mathrm{Nb}$ while those elements on the right are water-immobile (a combination of HFSEs and REEs), and compatibility increases away from $\mathrm{Nb}$ on either side.

The incompatible LILEs show strong enrichments over primitive mantle ( $\mathrm{Cs}, \mathrm{Rb}$ and $\mathrm{Ba}$ ) for all glass shards likely to coincide with enrichment by water-rich fluid flux from the subducting Pacific Plate or crustal contamination during melt ascent. Enrichments in Cs, $\mathrm{Rb}$ and $\mathrm{Ba}$ are in excess of $40-600$ times primitive mantle values (Figure 3.8). The removal of analyses with totals $<91.0 \mathrm{wt}$. \% should remove all of the altered glass (Section 3.1). Diagenetic alteration has been considered with regard to all Site 1124-C tephras and appears to be restricted to the oldest four tephras (Section 1.3.3). This enhances confidence in the assertion that the enrichments in LILEs (plus Li and B, discussed in Section 3.2.5) are associated with an arc-derived source. The relative depletion in $\mathrm{Sr}$ (only $\sim 1-10$ times higher than primitive mantle values) shown by all glass shards reflects fractional crystallisation of feldspars (plagioclase, and possibly K-feldspar) occurring in the magma preceding eruption. Both $\mathrm{Sr}$ and $\mathrm{Ba}$ can readily substitute into feldspar. Based on the lack of Ba depletion shown in Figure 3.8, it appears $\mathrm{Sr}$ was more preferentially partitioned into fractionating feldspar phases. Relative enrichment in Ba may result from sediments on the Pacific Plate undergoing dehydration from partial melting with progressive subduction, or the introduction of incompatible element rich continental crust during melt ascent to the surface. Both these processes mask the effects of fractional crystallisation on this element.

Water-immobile elements (Figure 3.8) show a general depletion compared to the LILEs, but remain elevated compared to primitive mantle values. Depletion is particularly noted for the HFSE Ti, which at times exhibits depletion well below primitive mantle values. 
This depletion is consistent with fractional crystallisation of titanomagnetite, and other FeTi oxides (e.g. ilmenite). Also worth noting is the moderate depletion in $\mathrm{Nb}$, which is considered insensitive to fractional crystallisation processes with low average abundances in the mantle wedge (Pearce and Peate, 1995); as well as enrichment in $\mathrm{Pb} / \mathrm{Ce}$; and enrichments in Th and $\mathrm{U}$.

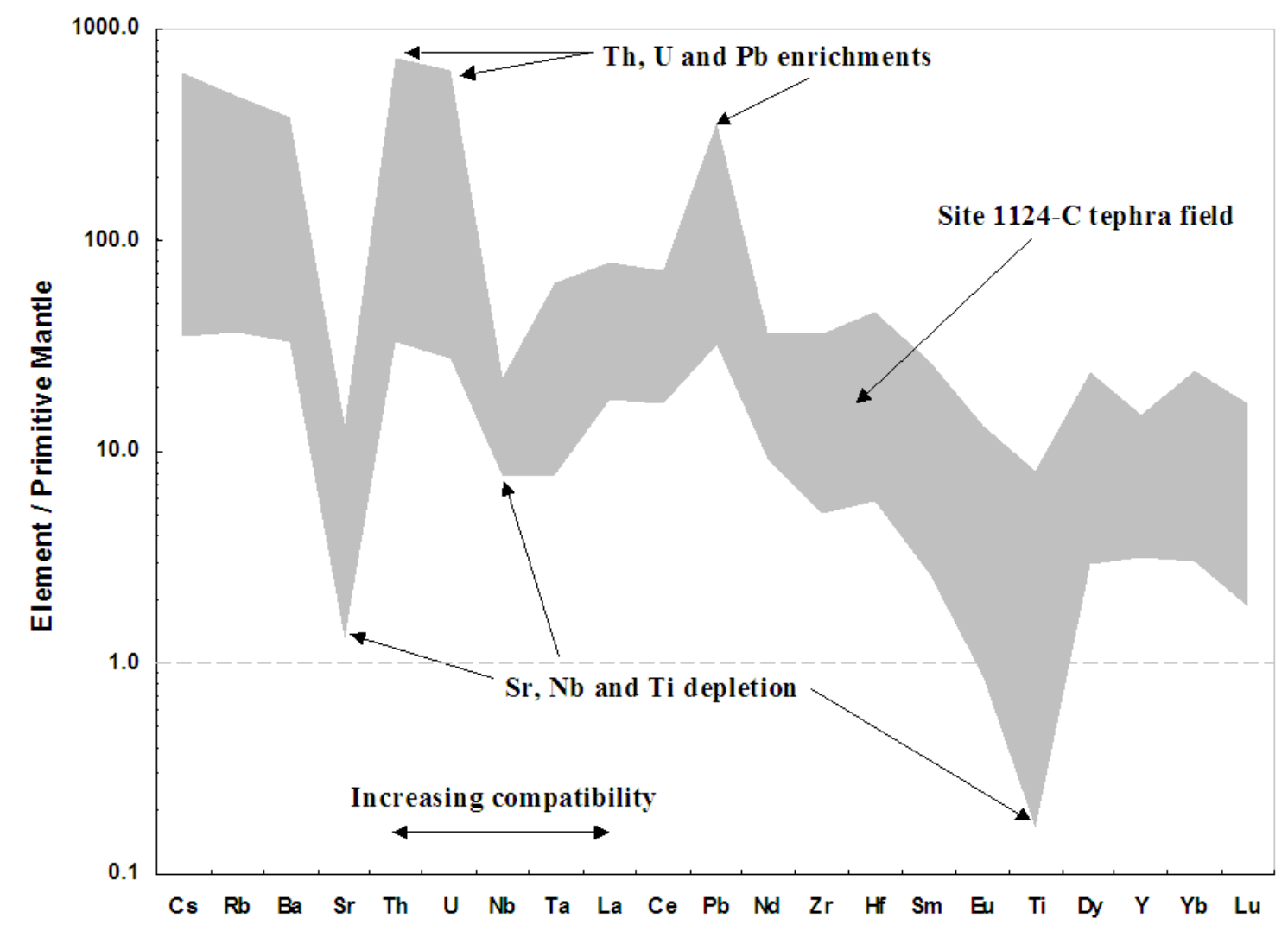

Fig. 3.8: Multi-element spider diagram demonstrating the range in values exhibited by Site 1124-C tephras normalised to primitive mantle values of Sun and McDonough (1989). Note the marked $\mathrm{Sr}$ and Ti depletion and enrichments in the LILEs, Th, $\mathrm{U}$ and $\mathrm{Pb}$. 


\subsubsection{Temporal Changes in Chemistry and Glass Composition}

Time-dependent variations in trace element concentrations demonstrate that the magma chemistry is responsive to changes in the arc by source (partial melting, input by slab and mantle wedge) and differentiation processes (varying degrees of fractional crystallisation, assimilation and magma mixing). Magmatic development of the $\mathrm{CVZ}$ can be traced by plotting a selection of key trace element ratios, as proxies for enrichment or depletion as a result of magma differentiation and source processes against age since 9.28 Ma (Figure 3.9). Selected trace element data have been plotted in Figure 3.10 to illustrate the variation and behaviour of these elements within CVZ magmas.

HFSE ratios can be used to draw inferences about the degree of wedge depletion from which parental magmas to CVZ eruptives were derived. CVZ magmas have undergone various degrees of crystal fractionation. $\mathrm{Nb} / \mathrm{Zr}$ (used by McCulloch and Gamble, 1991) is employed here in Figure 3.9 (other examples include Ti/Zr, V/Ti). This ratio, like most other HFSE ratios, may have been influenced by fractional crystallisation processes. Zirconium concentrations, in particular, appear to be influenced by zircon fractionation (Figure 3.10 a). However, differences in degree of partial melting or fractional crystallisation are believed to cause only small variations in HFSE ratios (Pearce and Peate, 1995). $\mathrm{Nb} / \mathrm{Zr}$ ratios are very low $(0.0247-0.147)$ and are relatively identical to $\mathrm{Nb} / \mathrm{Zr}$ ratios of the TVZ (Figure 3.9).

REE ratios (e.g. La/Yb) infer LREE relative to HREE enrichment. Figure 3.9 clearly indicates much LREE enrichment relative to HREE and can be related to source contributions to the $\mathrm{CVZ}$ magmas. $\mathrm{La} / \mathrm{Yb}$ ratios for $\mathrm{CVZ}$ magmas exhibit considerable variation which contrasts against very consistent values for TVZ derived magmas.

$\mathrm{K} / \mathrm{Rb}$ (and to a lesser extent $\mathrm{Cs} / \mathrm{Rb}$ ) are relatively elevated throughout the history of the $\mathrm{CVZ}$ which is consistent with derivation of parental magmas from a more depleted mantle source. $\mathrm{K} / \mathrm{Rb}$ and $\mathrm{Cs} / \mathrm{Rb}$ are incompatible LILE ratios and should not change greatly as a result of fractional crystallisation. $\mathrm{K} / \mathrm{Rb}$ ratios may be strongly altered through assimilation of crustal components (McMillan et al., 1993), or the interaction between magmas and the lower crust. LILE are water-mobile elements and may have an alternative source in aqueous slab-derived fluids. In particular, marine sediments have high $\mathrm{Cs} / \mathrm{Rb}$ but cannot account for elevated ratios in arc magmas (Pearce and Peate, 1995). K/Rb and 
$\mathrm{Cs} / \mathrm{Rb}$ ratios have greater variation in the older $\mathrm{CVZ}$ eruptive units (before $\sim 6 \mathrm{Ma}$ ) becoming more consistent through time, values of which are mimicked by eruptive units of the TVZ.

High $\mathrm{Ba} / \mathrm{La}$, high $\mathrm{Ba} / \mathrm{Nb}$, high $\mathrm{Ba} / \mathrm{Cs}$, low $\mathrm{Th} / \mathrm{Ba}$, low $\mathrm{Ce} / \mathrm{Pb}$, high $\mathrm{Sr} / \mathrm{Y}$ ratios highlight the extent to which the arc signature is developed. $\mathrm{Ba} / \mathrm{La}, \mathrm{Ba} / \mathrm{Nb}, \mathrm{Ba} / \mathrm{Cs}$, and $\mathrm{Ba} / \mathrm{Th}$ are indicators of slab fluid influence, whereas $\mathrm{Ce} / \mathrm{Pb}$ and $\mathrm{Sr} / \mathrm{Y}$ are indicators of slab sediment influence, in particular the slab sediment influence in the slab fluid component. The influence of subducted sediment on slab-derived fluids must decline at deeper levels within the subduction system as most or all of the sedimentary veneer is scraped off. LILEs (e.g. $\mathrm{Ba}, \mathrm{Cs})$ are water-mobile elements preferentially partitioned into aqueous fluids compared to water-immobile elements (e.g. $\mathrm{La}, \mathrm{Nb}, \mathrm{Th}$ ). Fractional crystallisation of feldspar may have operated to generate the slightly downward trend in the ratios involving $\mathrm{Ba}$. These ratios indicate that the slab fluid component involved in the melting process is variable throughout the history of the CVZ, becoming more consistent with time as the transition to the TVZ is approached. Li and B are considered diagnostic tracers of slab fluid flux and are discussed separately in the next section.

An important consideration is that many of these proxies for source and differentiation processes need to be interpreted with care as they may be influenced by several factors, some of which may have been ruled out above. These plots in Figure 3.9, for the most part, illustrate the variability in chemistry of early $\mathrm{CVZ}$ magmas. At $\sim 4 \mathrm{Ma}$, most ratios reveal a change to more coherent chemistries that persist to the CVZ-TVZ transition between $\sim 2 \mathrm{Ma}$ and 1.65 Ma. The concentrations and variability of trace element ratios in magma chemistry exhibited for CVZ eruptive units over $\sim 2 \mathrm{Myr}$ prior to commencement of TVZ explosive rhyolitic magmatism, appears to be maintained across this significant temporal and spatial boundary. 


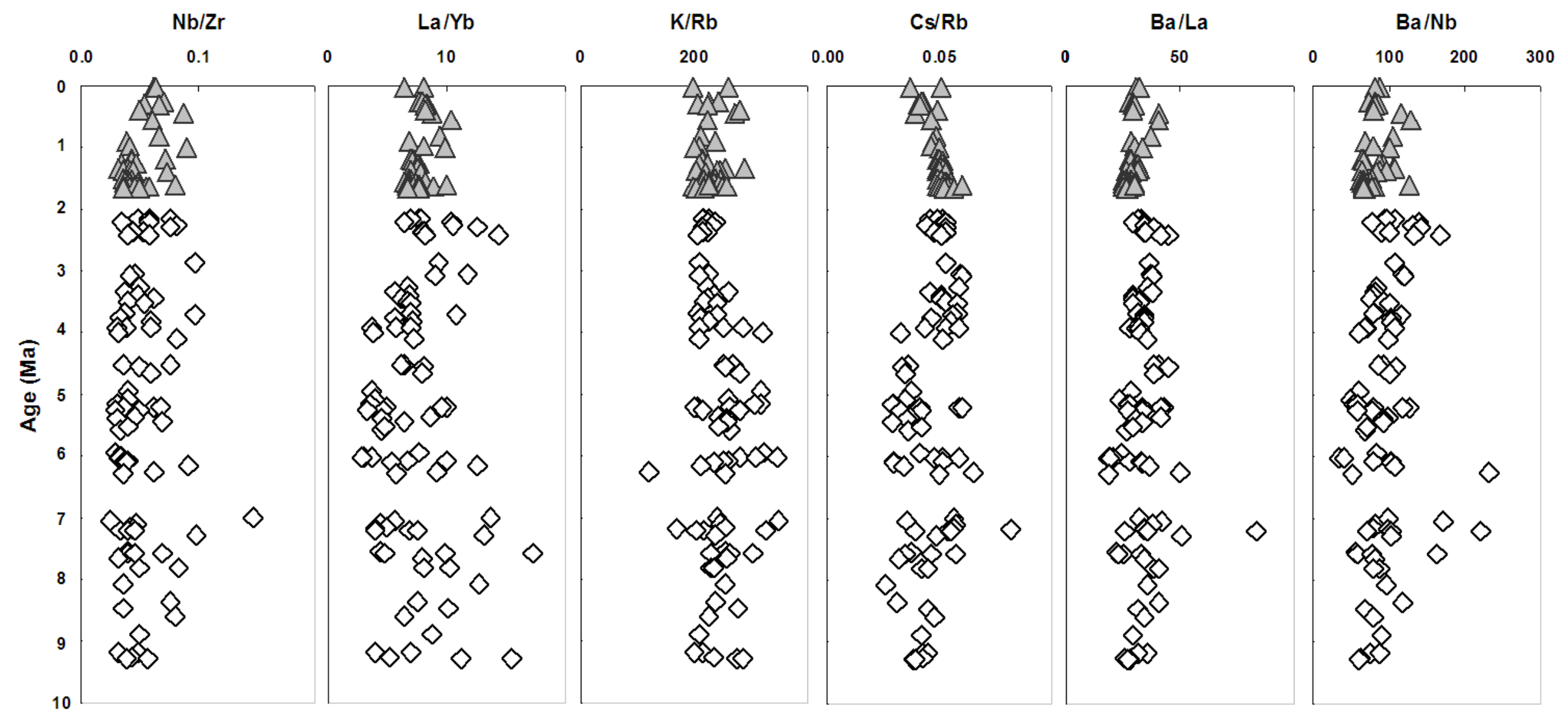

Fig. 3.9: The temporal evolution in selected key trace element ratios of tephras from Site 1124-C (white diamonds) since 10 Ma to 2 Ma. ODP Site 1123 Quaternary TVZ rhyolite tephra field (grey triangles) from Allan (2008). Each symbol represents the mean chemical composition of an individual eruptive unit. $\mathrm{Nb} / \mathrm{Zr}=\mathrm{HFSE}$ enrichment; $\mathrm{La} / \mathrm{Yb}=\mathrm{LREE}$ enrichment and crustal melting; $\mathrm{K} / \mathrm{Rb}=$ depleted mantle source and/or assimilation of crustal components; $\mathrm{Cs} / \mathrm{Rb}=$ depleted mantle source and/or slab sediment input; $\mathrm{Ba} / \mathrm{La}=$ slab fluid influence and crustal melting; $\mathrm{Ba} / \mathrm{Nb}=$ slab fluid influence and crustal melting. 


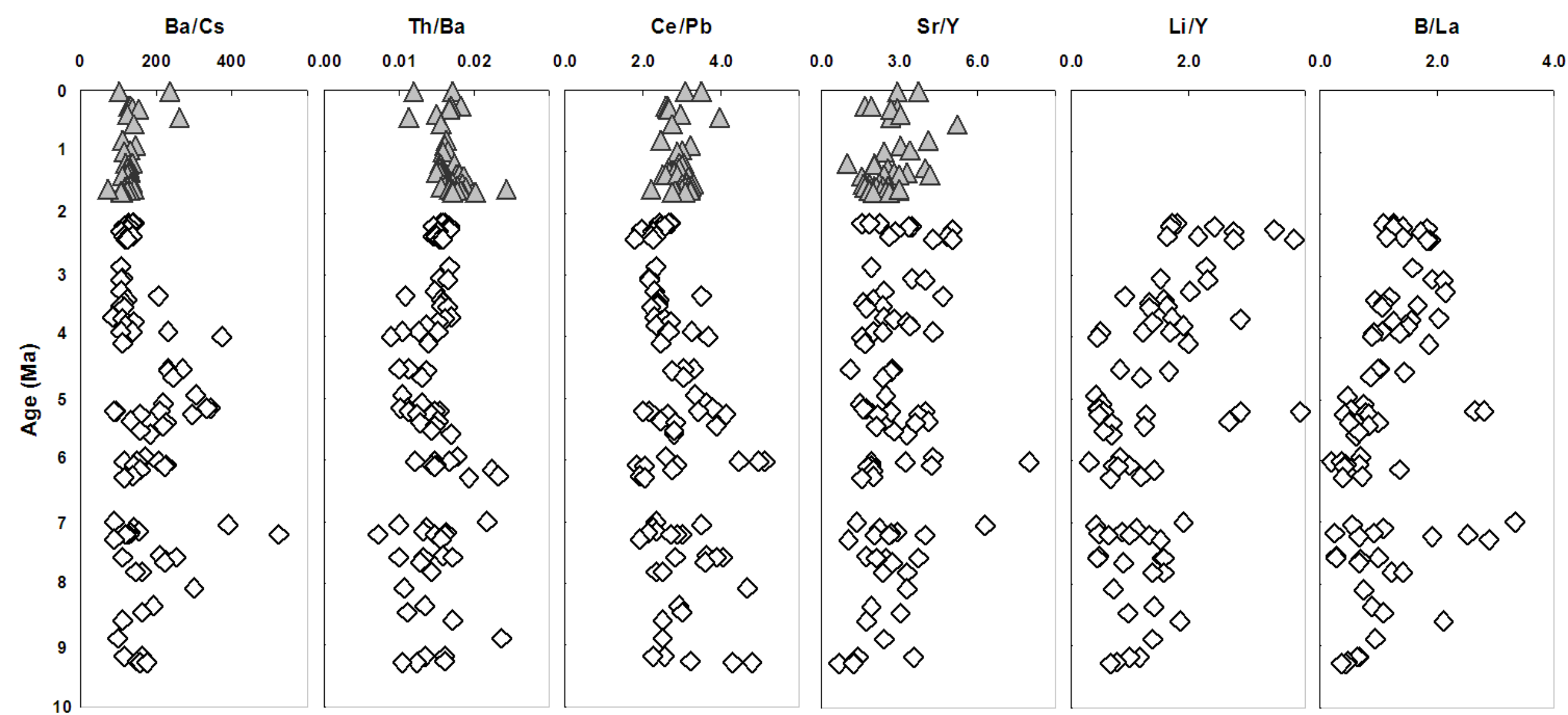

Fig. 3.9: Continued. $\mathrm{Ba} / \mathrm{Cs}=$ slab fluid influence; $\mathrm{Th} / \mathrm{Ba}=$ subducted sediment input $; \mathrm{Ce} / \mathrm{Pb}=$ sediment influence to the slab fluid component; Sr$/ \mathrm{Y}=$ subducted sediment input; $\mathrm{Li} / \mathrm{Y}=$ slab fluid influence; $\mathrm{B} / \mathrm{La}=$ slab fluid influence. Many of these proxies for source and differentiation processes need to be interpreted with care as they may be influenced by several factors (see text). 

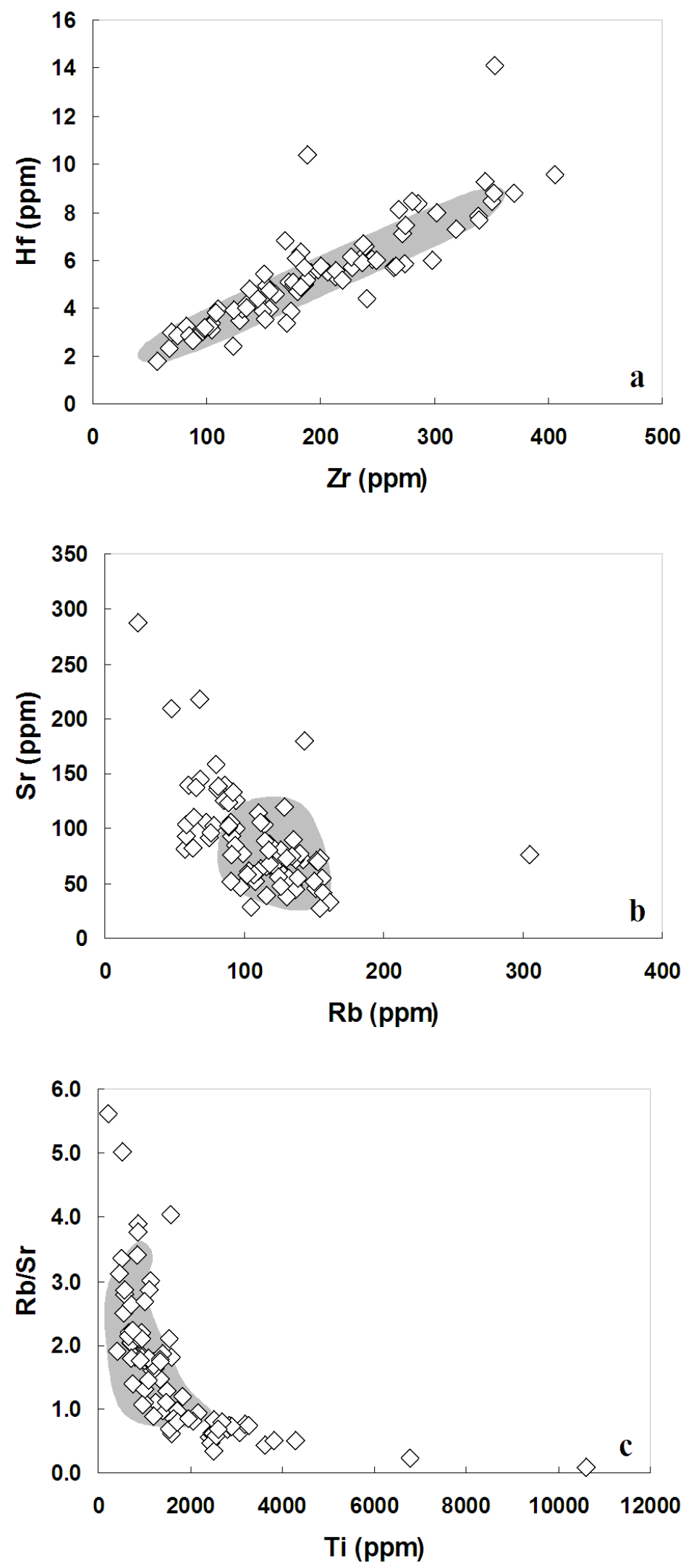

Fig. 3.10: Selected trace element data for Site 1124-C tephra layers. For all plots each white diamond represents the mean chemical composition of each tephra layer analysed by LA-ICP-MS. ODP Site 1123 Quaternary TVZ rhyolite tephra field (grey) is from Allan (2008). (a) Hf versus $\mathrm{Zr}$ (ppm), (b) Sr versus $\mathrm{Rb}$ (ppm), (c) $\mathrm{Rb} / \mathrm{Sr}$ versus Ti (ppm). 


\subsubsection{Lithium and Boron Geochemistry}

Presented here for the first time, are lithium (Li) and boron (B) trace element data obtained from volcanic glass shards sourced from New Zealand. The acquisition of $\mathrm{Li}$ and $\mathrm{B}$ data from Site 1124-C tephras is used in an attempt to provide a reliable means for assessing (i) the behaviour of light, fluid-mobile elements associated with the subduction zone that existed between the Pacific and Australian Plates during the history of the CVZ, and (ii) how fluid flux affects petrogenesis and the concentrations of other element groups.

Low atomic mass elements, such as $\mathrm{Li}$ and $\mathrm{B}$, are viewed as powerful sensitive tracers that can be used to evaluate the involvement of subducted materials (sedimentary veneer and altered oceanic crust) in the petrogenesis of arc magmas (e.g. Brenan et al., 1998; Sano et al., 2001). Li and B are enriched in altered oceanic crust and marine sediments relative to the mantle and are readily mobilised from these sources into aqueous fluids (e.g. Chan and Kastner, 2000). During mineral breakdown and dehydration (producing aqueous fluids) Li and $\mathrm{B}$ are released from altered oceanic crust and marine sediments. Lithium is preferentially enriched in the sedimentary veneer of the subducting slab relative to the altered oceanic crust as a result of interaction with seawater (Tomascak et al., 2000). The ultimate fate of the subducted slab is to become recycled into the sub-arc mantle. Li and B may become transported within aqueous fluids as a result of dehydration or within silicic fluids by partial melting of the subducting slab. Fluid-mediated slab to mantle transfer initiates melting of the mantle wedge meaning that parts of the subducted material may be recycled to the arc crust during hydration of upper mantle sources (Sano et al., 2001).

In order to trace the source of magmatic Li and B, two proxies for slab flux are employed; $\mathrm{Li} / \mathrm{Y}$ and $\mathrm{B} / \mathrm{La}$ (Figure 3.9). Each ratio can be considered as representing an element that is enriched in the sedimentary veneer atop the subducting plate or altered oceanic crust (Li and $\mathrm{B}$ ) relative to the mantle wedge, and another element that is not. Other proxies involving mobile/immobile element ratios for slab flux (e.g. $\mathrm{Ba} / \mathrm{Zr}$ or $\mathrm{B} / \mathrm{Zr}$ ) have been considered appropriate in past studies (e.g. Sano et al., 2001). However, these ratios may reflect contributions from both slab flux and fractional crystallisation processes and thus require caution in their interpretation. For example, $\mathrm{Zr}$ is a fluid immobile and incompatible element that may exhibit variable behaviour in the presence of $\mathrm{Zr}$-saturated silicic magmas (e.g. Figure 3.10). Yttrium has been utilised due to its hydrophobic character and its similar partitioning during fractional crystallisation closely emulates that 
of Li (Ryan and Langmuir, 1987). This means Li and Y are similarly compatible in igneous phases therefore the effects of fractional crystallisation on the Li/Y ratio are minimised as $\mathrm{Li}$ is normalised to $\mathrm{Y}$. Boron is a relatively fluid mobile element in aqueous fluids and is commonly combined with other incompatible, fluid-immobile elements (Leeman et al., 1994), e.g. La in this study, to recognise the contribution of subducted materials to CVZ arc magmas through time. Nicholson et al. (2004) have isotopically shown the presence of oceanic sediment in the petrogenesis of early CVZ magmas; $\mathrm{Li} / \mathrm{Y}$ and $\mathrm{B} / \mathrm{La}$ values are indicators of slab-fluid input in arc petrogenesis and will be used to infer source characteristics.

$\mathrm{Li}$ and B concentrations from Site 1124-C tephras are plotted against age in Figure 3.11. Higher values reflect selective addition of Li or B to arc magma sources or by some means of addition of Li or B to a partially differentiated magma. Systematic heterogeneity of Li and $\mathrm{B}$ in $\mathrm{CVZ}$ magma sources may have existed on a regional scale. Li and B values show a gradual increase in concentration from $\sim 6.3 \mathrm{Ma}$ to $2 \mathrm{Ma}$, indicating progressive enrichment of these elements in CVZ arc magmas and their sources. Prior to $\sim 6.3 \mathrm{Ma}, \mathrm{Li}$ and $\mathrm{B}$ concentrations were highly variable, with no coherent trend. Li and B concentrations (Figure 3.11) can be compared to ratios of slab fluid flux, $\mathrm{Li} / \mathrm{Y}$ and B/La, in Figure 3.9. Both $\mathrm{Li} / \mathrm{Y}$ and $\mathrm{B} / \mathrm{La}$ ratios mimic $\mathrm{Li}$ and $\mathrm{B}$ in progressive enrichment through time, however Li/Y and B/La plots identify (more clearly) periods when slab fluid flux appears to be more intensified. These periods occur at 5.4-5.2 Ma, 3.72 Ma and 2.452.25 Ma for $\mathrm{Li} / \mathrm{Y}$, whereas $\mathrm{Li}$ abundances only depict an intensified period at $\sim 5.2 \mathrm{Ma}$. $\mathrm{B} / \mathrm{La}$ displays strengthened periods of slab fluid flux at 8.61 Ma, 7.3-7.0 Ma and 5.2 $\mathrm{Ma}$, which are similar to $\mathrm{B}$ abundances. It is apparent that some common event is reflected in both Li and B data at 5.2 Ma. Although Li/Y and B/La plots show considerable coherency through time, slightly elevated $\mathrm{Li} / \mathrm{Y}$ and $\mathrm{B} / \mathrm{La}$ ratios may indicate the involvement of subducted material and support subduction of even the smallest amount of marine sediment or altered oceanic crust. 


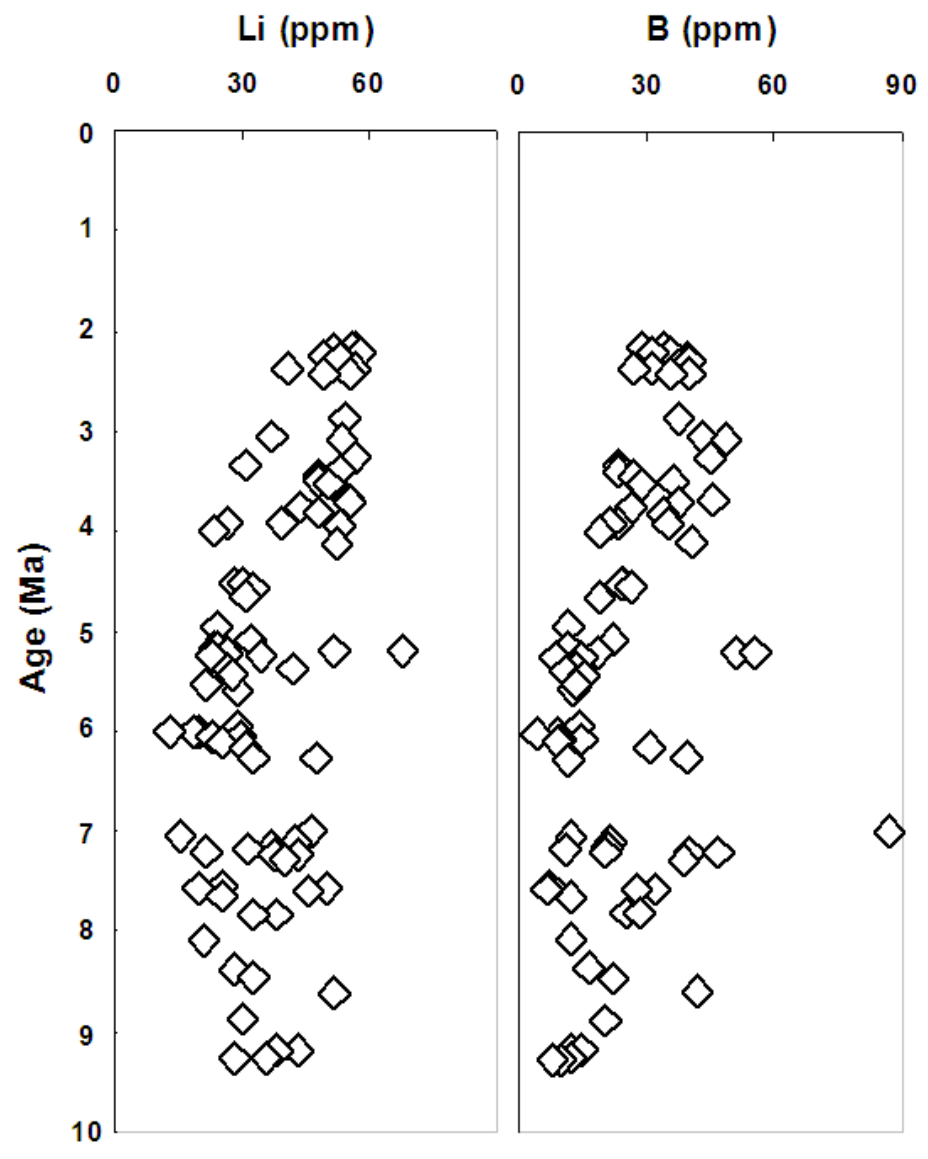

Fig. 3.11: The temporal evolution of $\mathrm{Li}$ and $\mathrm{B}$ analysed in tephras from Site 1124-C from $10 \mathrm{Ma}$ to $2 \mathrm{Ma}$. Higher values reflect selective addition of Li or B to arc magma sources. Each symbol represents the mean chemical composition of an individual eruptive unit.

$\mathrm{Li}$ and $\mathrm{Li} / \mathrm{Y}$ values increase with increasing $\mathrm{SiO}_{2}$ concentration (Figure $3.12 \mathrm{a}$ and $\mathrm{b}$ ) implying that Li becomes more enriched in the magma as it evolves. This was previously recognised by Clift et al. (2005) who state that Li becomes enriched in the magma when melt composition reaches the rhyolitic range, concluding that an increase of $\mathrm{Li}$ and/or $\mathrm{Li} / \mathrm{Y}$ corresponds with an increase of $\mathrm{SiO}_{2}$ as a combined effect from fractional crystallisation and sediment/crust assimilation. In this study, individual tephras do not exhibit relative Li enrichment in the presence of a more silica-rich magma. For example, eruptive unit M-36 $\mathrm{SiO}_{2}=77.7$ (wt. \%), $\mathrm{Li}=68.0$ (ppm); whereas eruptive unit $\mathrm{M}-47$ (2) $\mathrm{SiO}_{2}=77.8$ (wt. \%), $\mathrm{Li}=22.8(\mathrm{ppm})$. 
Similarly, $\mathrm{B}$ and $\mathrm{B} / \mathrm{La}$ values increase with increasing $\mathrm{SiO}_{2}$ concentration (Figure $3.12 \mathrm{c}$ and d) implying that $\mathrm{B}$ becomes more enhanced to the magma as it evolves. It is maintained that individual tephras do not exhibit relative B enrichment in the presence of a more silica-rich magma. For example, eruptive unit $\mathrm{M}-36 \mathrm{SiO}_{2}=77.7$ (wt. \%), $\mathrm{B}=55.7$ (ppm); whereas eruptive unit M-47 (2) $\mathrm{SiO}_{2}=77.8$ (wt. \%), $\mathrm{B}=10.2$ (ppm). These data may indicate that fractional crystallisation does not play a major role in controlling B concentrations in silicic melts and variations are therefore a response to higher-level source processes (like Li). Based on this study and Leeman et al. (1994) (who compared B/Zr ratios as precise La data for all samples was absent), variations in ratios of $\mathrm{B}$ to $\mathrm{La}$, as a result of fractional crystallisation, are insignificant. It seems plausible to conclude that $\mathrm{Li} / \mathrm{Y}$ and $\mathrm{B} / \mathrm{La}$ ratios are not very sensitive to magma differentiation; meaning crystal fractionation processes are insignificant in controlling Li and B behaviour. 

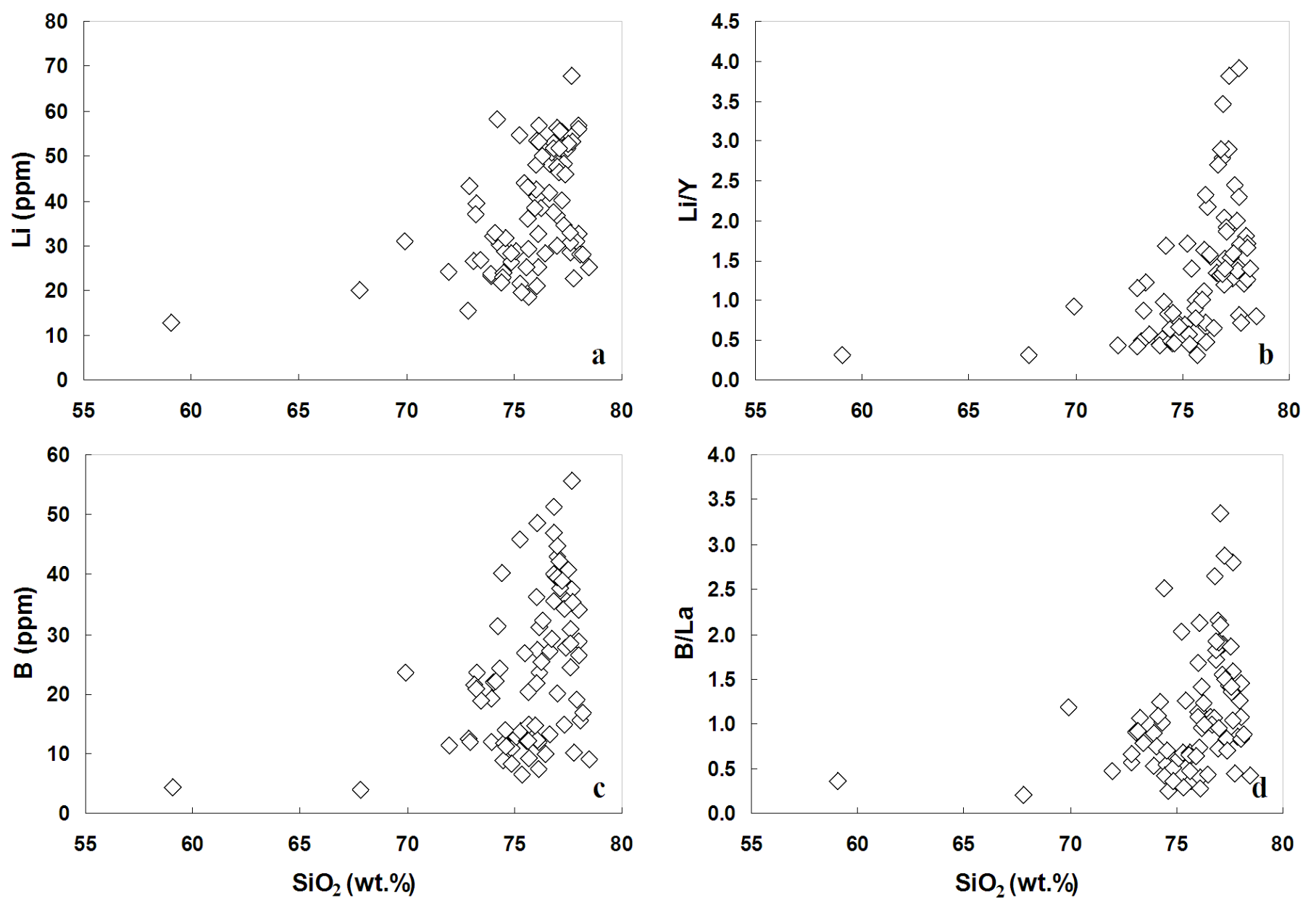

Fig. 3.12: Selected $\mathrm{Li}$ and B trace element data for Site 1124-C tephra layers. For all plots each diamond represents the mean chemical composition of each tephra layer. (a) $\mathrm{Li}$ (ppm) versus $\mathrm{SiO}_{2}$ (wt. \%), (b) $\mathrm{Li} / \mathrm{Y}$ versus $\mathrm{SiO}_{2}$ (wt. \%), (c) B (ppm) versus $\mathrm{SiO}_{2}$ (wt. \%), (d) $\mathrm{B} / \mathrm{La}$ versus $\mathrm{SiO} 2$ (wt. \%). 
Figure 3.13 shows the relationship involving B/La compared to LREE enrichment (e.g. $\mathrm{La} / \mathrm{Yb}$, see Section 3.2.1). It is clear that moderate positive co-variation exists whereby higher $\mathrm{B} / \mathrm{La}$ values generally have higher $\mathrm{La} / \mathrm{Yb}$ values. Some samples show stronger LREE enrichment (high $\mathrm{La} / \mathrm{Yb}$ ) compared to $\mathrm{B} / \mathrm{La}$ values (Figure 3.13, blue field). The samples represented in the blue field correspond to four geochemical units erupted in the early history of the CVZ (M-65, M-67 and M-72 (1 and 2)) at a time when explosive magmatism in the CVZ was in its infancy and subduction signatures were poorly developed. These four eruptive units are also characterised by high $\mathrm{Nb} / \mathrm{Yb}$ ratios implicating source processes, for example, small-degree partial melting of a depleted mantle wedge, in the generation of some early CVZ magmas.

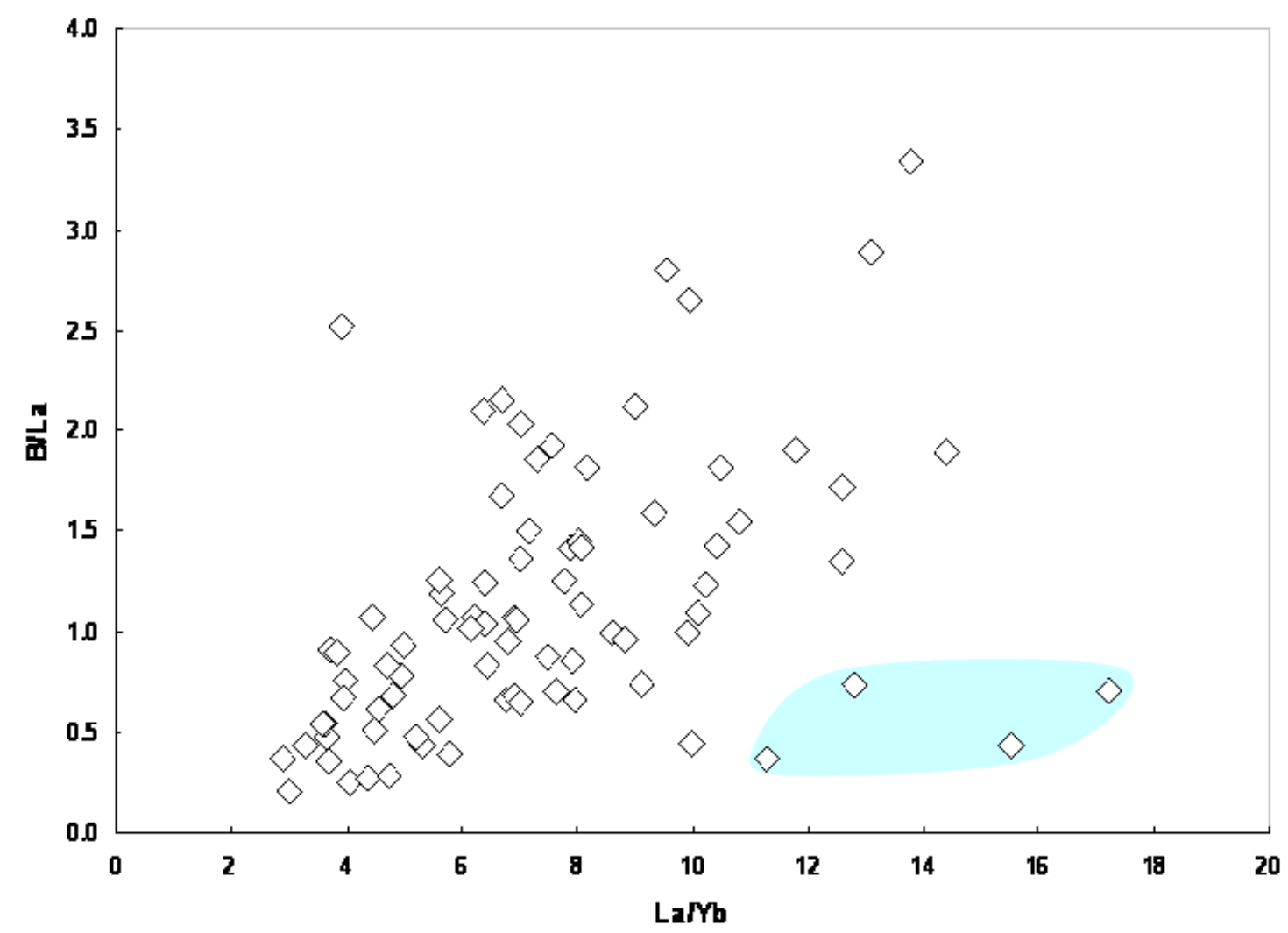

Fig. 3.13: Plot of $\mathrm{B} / \mathrm{La}$ versus $\mathrm{La} / \mathrm{Yb}$ showing moderate positive co-variation between slab fluid flux (measured by $\mathrm{B} / \mathrm{La}$ ) and LREE enrichment (measured by $\mathrm{La} / \mathrm{Yb}$ ) in mean glass shard compositions. This may be suggestive of slab fluid flux involvement causing enrichments in LREE. The blue field represents samples that indicate additional source process in the generation of some CVZ magmas. 


\subsection{Discussion}

\subsection{Intra-tephra Variation}

Tephra trace element data have the potential to reveal information on the processes responsible for the chemical variability in the silicic melts which produced Site 1124-C tephras. Single glass shard chemical variation within individual tephras provides a snapshot of zoned silicic magma chambers prior to eruption. This can be demonstrated by comparing the major and/or trace element data for tephras retrieved at Site 1124-C. The variations in trace element concentrations within individual tephra samples described below are considerably greater than the analytical uncertainty of the LA-ICP-MS technique $(\sim \pm 5-10 \%)$.

\subsubsection{Bimodality}

It is possible to distinguish the existence of multiple geochemical populations within an individual tephra layer. The major element data alone would suggest that the majority of glass shards within individual tephra layers have narrow compositional ranges (plotting in relatively discrete groups). However, ten samples analysed contain populations of glass shards (population being defined here as $\sim \geq 4$ ) that represent more than one geochemical population. This is demonstrated by comparing selected major element and trace element data for two (one late Miocene and one late Pliocene) tephras recovered at Site 1124-C, M2 (AT-313, 1124C-7H3, $120 \mathrm{~cm}$ ) and M-61 (1124C-16H2, $64 \mathrm{~cm}$ ) (Figure 4.1). A plot of $\mathrm{CaO}$ versus $\mathrm{FeO}_{\mathrm{t}}$ (wt. \%) for both samples (Figure $4.1 \mathrm{a}$ and $\mathrm{b}$ ) shows overlap between the respective geochemical groupings. In contrast, a plot of $\mathrm{Zr} / \mathrm{Th}$ versus $\mathrm{Sr} / \mathrm{Y}$ (Figure $4.1 \mathrm{c}$ ) for sample M-2 shows a clear departure in the chemical fingerprint of each glass shard population. Sample M-61 shows a similar feature, with an obvious deviation between two populations on a plot of $\mathrm{Ti}(\mathrm{ppm})$ versus $\mathrm{Rb} / \mathrm{Sr}$ (Figure $4.1 \mathrm{~d}$ ). However, the more differentiated population (grey triangles) exhibits a wider range of internal variability $(\mathrm{Rb} / \mathrm{Sr}=1.57-2.10)$ compared to the more primitive population $(\mathrm{Rb} / \mathrm{Sr}=0.48-0.64)$. Trace element data can clearly reveal chemically distinct populations within an individual 
tephra deposit, if they are present. Given their similar major element chemistry, there is significant potential for overlooking the bimodal nature of these and similar tephras, which would otherwise be viewed as homogeneous on major element data alone. Distinction of more than one geochemical population (within tephra layers recovered at Site 1124-C) would not have been possible without trace element data acquired by LA-ICP-MS, highlighting the effectiveness of this analytical technique in the discrimination of tephras with very similar major element chemistries.

The origins of the bimodal geochemical nature of many tephra deposits can potentially be explained by three processes: (1) compositional differences between different magmas whose products were physically mixed after eruption, (2) contemporaneous volcanic eruptions from geographically different source volcanoes, or (3) through the sequential or simultaneous eruption of multiple magma bodies in the conduit of the source volcano. It is reasonable to envision that pre-existing ash deposits could become entrained into an eruption column or mixed during transport and deposition. However, it does not seem logical that accidental material could produce the constancy in chemical composition exhibited by glass shards in the Site 1124-C tephras (for example, M-2). It could be expected that accidental incorporation of pre-existing ash deposits would yield relict anomalous shards within a tephra deposit that would plot outside of the main population but not be in sufficient quantity to represent a second geochemical grouping. This is observed at Site 1124-C as relict andesitic and dacitic glass shards in the predominantly rhyolitic tephra layers. Therefore, it seems credible that ash from an explosive rhyolitic eruption could have accumulated small amounts of more primitive ash deposits during transport and deposition. Statistically, the likelihood that a volcanic eruption will be followed by further eruptions increases after the initial eruption. However, the likelihood that more than one explosive eruption has occurred in close temporal proximity to another at least ten times throughout the history of the CVZ seems doubtful. Bimodal tephra populations are cited in Hildreth (1981) as representing gaps in magma composition. This could reflect a long duration eruption whereby only specific eruption phases are preserved, or the sequential eruption of multiple magma bodies having undergone various degrees of fractionation. In all distal ash deposits at Site 1124-C, the compositional diversity arising from the mixing of the products of separate magmas cannot be neglected. 

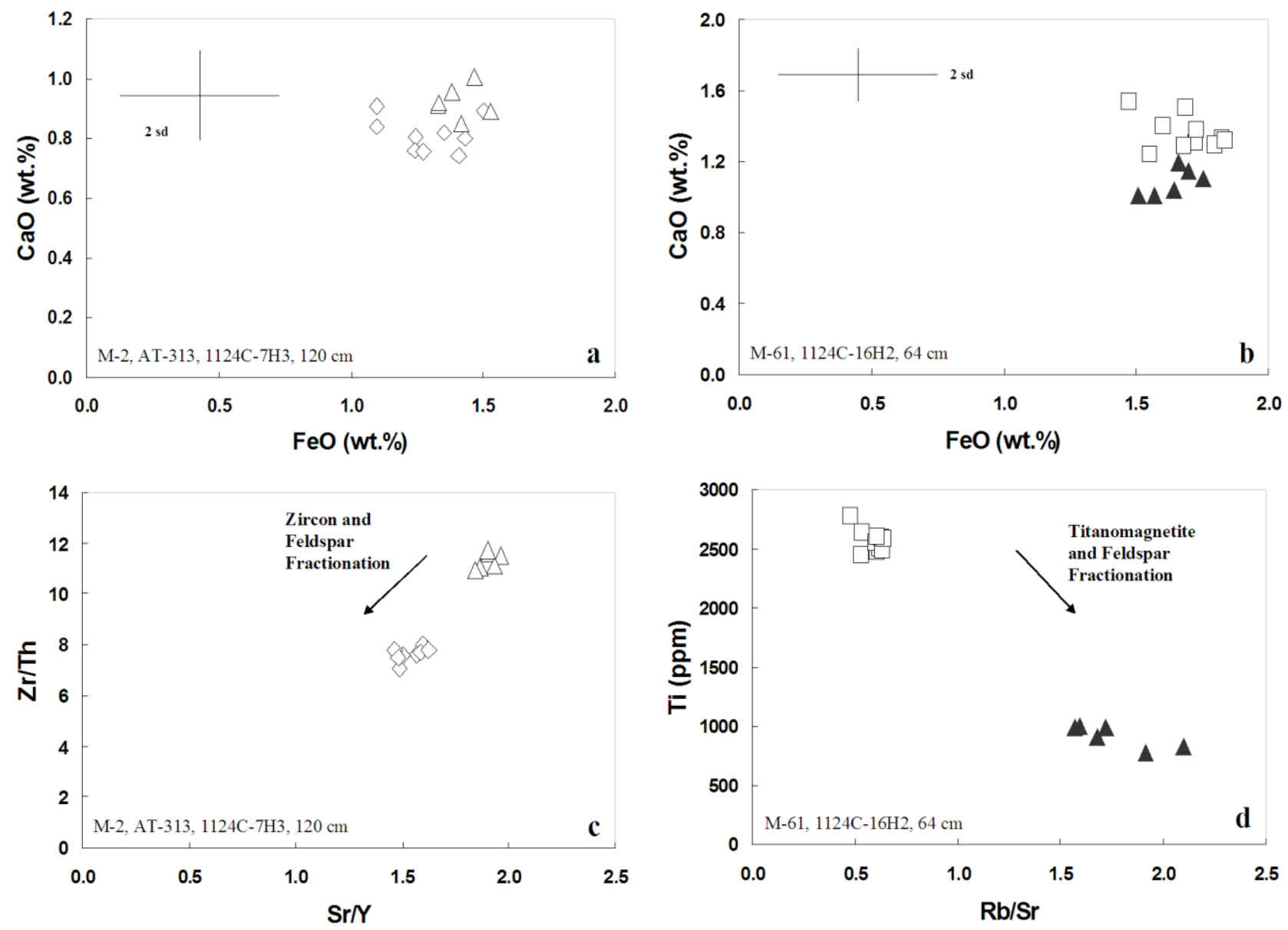

Fig. 4.1: Selected major, minor and trace element data for two Site 1124-C tephras that exhibit bimodal intra-tephra variability, M-2 (AT-313, 1124C-7H3, $120 \mathrm{~cm})$ and M-61 (1124C-16H2, $64 \mathrm{~cm})$. Each symbol represents an individual glass shard analysis by EPMA (for a and b) and LA-ICP-MS (for c and d). Note that based on EPMA data alone, samples M-2 and M-61 would be considered homogeneous. (a) M-2 CaO versus FeO (wt. \%), (b) M-61 CaO versus $\mathrm{FeO}$ (wt. \%), (c) M-2 Zr/Th versus $\mathrm{Sr} / \mathrm{Y}$, (d) M-61 Ti (ppm) versus Rb/Sr. 


\subsubsection{Crystal Fractionation}

The tephra layers at Site 1124-C demonstrate varying degrees of fractional crystallisation (Figure 4.2). The majority of tephras display chemical variation (however minor) that can be explained by fractionation of various mineral assemblages, predominantly plagioclase and alkali feldspar, zircon, \pm titanomagnetite, \pm biotite. Figure 4.2 (a) presents the most extremely fractionated sample, M-12 (with the exception of sample M-46, see below) from the suite of tephras recovered at Site 1124-C. Zirconium and Sr are characteristically incompatible elements. In $\mathrm{Zr}$-saturated, silicic magmas $\mathrm{Zr}$ (and $\mathrm{Hf}$ ) will behave compatibly; $\mathrm{Sr}$ will substitute readily for $\mathrm{Ca}$ in plagioclase and $\mathrm{K}$ in alkali feldspar. Zirconium concentrations range from $\sim 66-285 \mathrm{ppm}$ in positive co-variation with $\mathrm{Sr}$, ranging from $\sim 42-126 \mathrm{ppm}$, reflecting extensive zircon and feldspar crystallisation respectively. Sample M-46 was introduced in Section 3.1.1 with reference to a spectrum of glass shard compositions ranging from andesite to rhyolite (Figure $4.2 \mathrm{~b}$ ). A plot of $\mathrm{Sr}$ (ppm) versus $\mathrm{CaO}$ (wt. \%) would suggest that considerable plagioclase crystallisation has occurred in the evolution of this silicic melt. A plot of V versus Ti (ppm) (Figure $4.2 \mathrm{c}$ ) shows representative ilmenite or titanomagnetite crystallisation for sample M-26, phases for which $\mathrm{V}$ and Ti are both compatible elements.

The spread of analyses along a chemical trend, such as those shown in Figure 4.2 (a and c) can be interpreted as representing compositional gradients (Hildreth, 1981) in the source magma and may potentially contribute to the variability in glass shard compositions within individual tephras at Site 1124-C.

\subsubsection{Diffusive Variability, Homogeneity and Magma Mixing}

Not all tephra samples exhibit bimodality or crystal fractionation. Figure 4.3 (a-c) illustrates some exceptions. Diffuse variation present in some tephras is due to (a) differential diffusion rates of different trace elements in these viscous magmas and/or (b) mingling of variously fractionated silicic melts causing local compositional variation as a result of (a) above (for example, M-36; Figure 4.3 a). Less evolved tephras (for example, M-19) appear more progressively homogenised (Figure $4.3 \mathrm{~b}$ ) owing to minimal effect of crystal fractionation. The ability to recognise magma mixing trends in the Site 1124-C tephras appears limited to plots of Th versus $\mathrm{Sr}$ (ppm). 

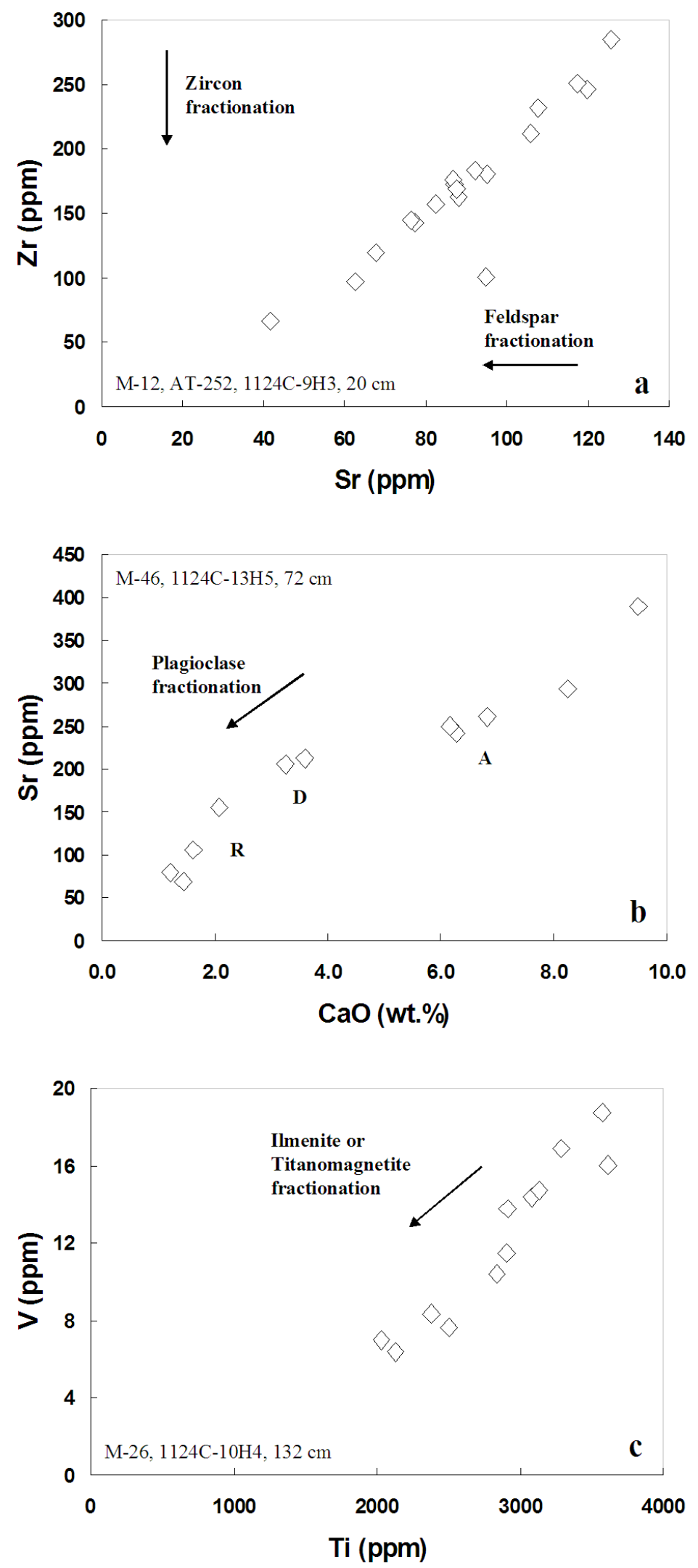

Fig. 4.2: Selected major, minor and trace element data for Site 1124-C tephras that exhibit various degrees of fractionation, M-12 (AT-252, 1124C-9H3, $20 \mathrm{~cm}$ ), M-46 (1124C-13H5, $72 \mathrm{~cm})$ and M-26 (1124C-10H4, $132 \mathrm{~cm})$. Each symbol represents an individual glass shard analysis by LA-ICP-MS. (a) M-12 $\mathrm{Zr}$ versus $\mathrm{Sr}$ (ppm), (b) M-46 Sr (ppm) versus $\mathrm{CaO}$ (wt. \%), (c) M-26 V versus $\mathrm{Ti}$ (ppm). A = andesite, $\mathrm{D}=$ dacite, $\mathrm{R}=$ rhyolite in (b). 

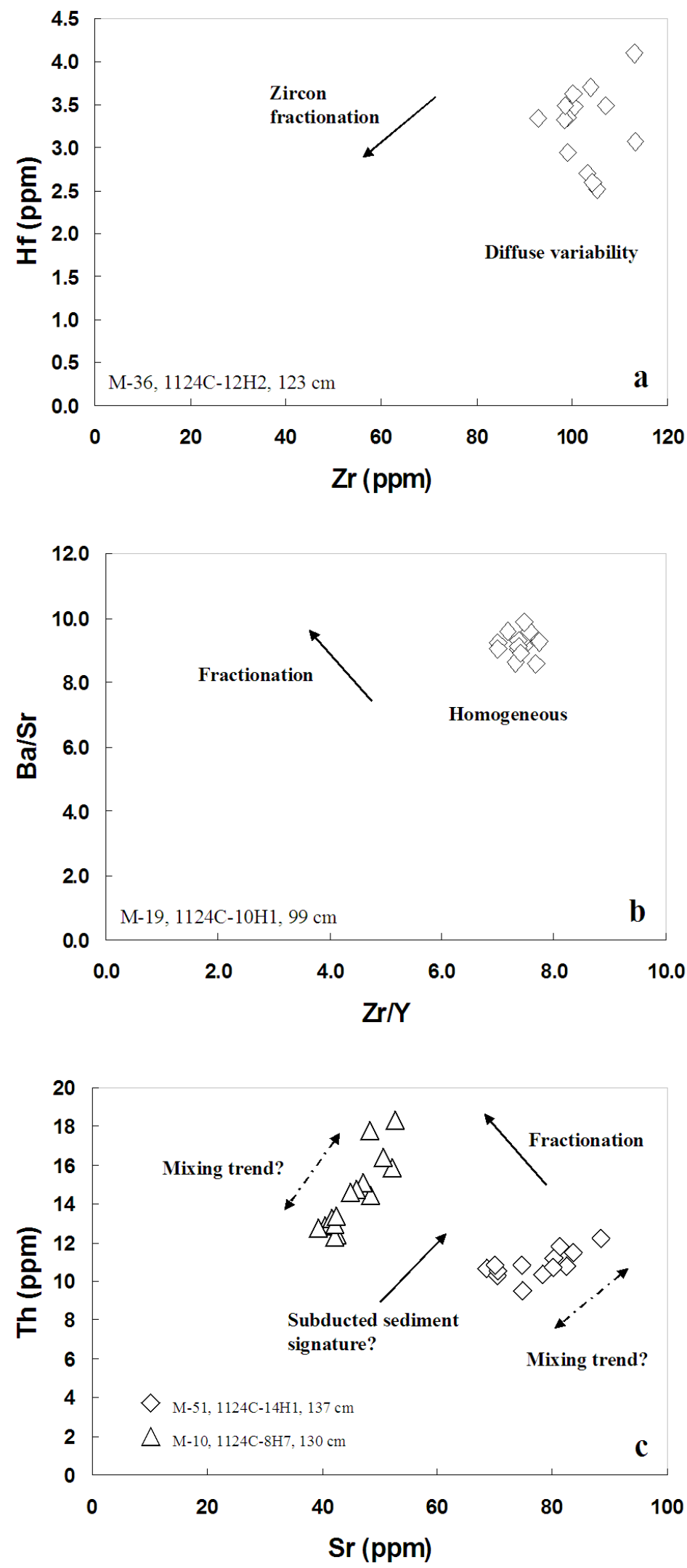

Fig. 4.3: Selected major, minor and trace element data for two Site 1124-C tephras that exhibit diffuse variability (a), homogeneity (b) and mixing (c), M-36 (1124C-12H2, 123 $\mathrm{cm})$, M-19 (1124C-10H1, $99 \mathrm{~cm})$, M-51 (1124C-14H1, $137 \mathrm{~cm})$ and M-10 (1124C-8H7, $130 \mathrm{~cm}$ ). Each symbol represents an individual glass shard analysis by LA-ICP-MS. (a) M$36 \mathrm{Hf}$ versus $\mathrm{Zr}$ (ppm), (b) M-19 Ba/Sr versus $\mathrm{Zr} / \mathrm{Y}$, (c) M-51 and M-10 Th versus $\mathrm{Sr}$ (ppm). 
Th is a highly incompatible element, the concentration of which would be expected to increase in the remaining melt when plotted with $\mathrm{Sr}$ (behaving compatibly as a result of feldspar removal). Figure 4.3 (c) shows the uncharacteristic behaviour of Th for samples M-10 and M-51. It has been argued that high Th concentrations are possibly explained by incorporation of large amounts of sediment (Bryant et al., 1999). Alternatively, other studies (Elliot et al., 1997) argue for high Th concentrations reflecting involvement of partially melted sediments in arc magma petrogenesis.

\subsubsection{Potential Analytical Artefacts in Secondary Data Normalisation}

It is important to consider whether the variations exhibited by the tephras at Site 1124-C reflect the true chemical variability in their corresponding source melts just prior to eruption, or if these variations are the result of analytical artefacts. Variations in the trace element concentrations within individual tephras (as mentioned earlier), are greater than the $\sim \pm 5-10 \%$ analytical uncertainty of the LA-ICP-MS technique. Utilisation of ${ }^{29} \mathrm{Si}$ (analysed by EPMA) as the internal standard isotope for secondary data normalisation (see Chapter 2, Table 2.4), may have inadvertently introduced variations, particularly positive co-variations, between elemental concentrations. There are three lines of explanation to suggest that this is not the case. First, the relatively low uncertainty of $\mathrm{SiO}_{2}$ (wt. \%) measurements obtained by EPMA for the high-Si, CVZ-derived rhyolites at Site 1124-C was only $\pm 4.2 \%$ (2 sd relative). Secondly, an analytical artefact would be expected to result in positive covariations (that are absent in this dataset) between plots of incompatible elements (e.g. $\mathrm{Rb}, \mathrm{Nb}, \mathrm{La}$ ) against compatible elements (e.g. $\mathrm{Mg}, \mathrm{Zr}$ and $\mathrm{Sr}$ if behaving compatibly). Thirdly, ratios of trace element pairs are unaffected by the secondary internal normalisation process and the influence of an analytical artefact is negligible (if present at all) allowing the recognition of small scale heterogeneity in the melt before eruption. 


\subsection{Temporal Evolution and the CVZ-TVZ Transition}

\subsubsection{Tempo of Explosive Silicic Eruptions from the CVZ}

This thesis has revealed that the 72 unaltered macroscopic Miocene - Pliocene tephra layers correspond to $\sim 83-84$ individual (geochemical) units or eruptive events. This thesis reports eruptive frequencies in Section 1.3.4 based on the number of preserved eruptive units per time interval to be one per $120 \mathrm{kyr}$ for the late Miocene and one per 82 kyr for the Pliocene ( $n=33$ and 39 respectively). Revised eruptive frequencies based on the number of geochemical units/eruptive events identified constitutes at least one every 99 kyr for the late Miocene and one per $74 \mathrm{kyr}$ for the Pliocene ( $\mathrm{n}=40$ and 43 respectively). As discussed in Section 1.3.4, the frequency of tephra deposition throughout the history of the CVZ has not been constant, rather reflecting pulses of major explosive eruptions resulting in closely clustered groups of tephras separated by periods of reduced major activity, relative volcanic quiescence or non-tephra deposition. Therefore these eruptive frequencies are likely to be too low due to gaps in the marine tephra record. Gosson (1986) documented at least 830 silicic tuffs deposited in the East Coast Basin of New Zealand between $24 \mathrm{Ma}$ and 3.5 Ma, representing an average frequency of about one eruption every $25 \mathrm{kyr}$. These data support the contention that breaks in major volcanism are present in the tephra sequence recorded at Site 1124-C, and that eruptive frequencies should be much higher.

It is important to assess the validity of using macroscopic tephra layers from the deep-sea sedimentary sequence retrieved at Site 1124-C as a measure of the general explosive volcanic behaviour of the CVZ. There are three primary processes that may, at some point, have influenced the distribution of volcanic ash toward Site 1124-C. First, as the Pacific Plate approaches the source volcanoes, the likelihood for younger tephra layers to be deposited increases. Secondly, chemical diagenetic alteration with increasing depth (and age) can alter glass shards to form clayey laminae, reducing the number of preserved tephra layers. Lastly, the direction and strength of prevailing winds controlling the distribution of ash over land and sea may change over time. 
Neogene plate tectonic reconstructions of the Australian-Pacific plate boundary (King, 2000) show that the location of ODP Site 1124-C during the late Miocene was further away from the CVZ than the present day. This suggests that the opportunity for ash deposits to accumulate increased as plate motion moved the location of Site 1124-C progressively closer to the source volcanoes of the CVZ with time. This is reflected in the increase in eruptive frequency through the late Miocene and Pliocene. However, onshore studies indicate an apparent bimodal relationship between basaltic, andesitic, dacitic and rhyolitic volcanism evidenced by a varied suite of rock compositions of similar age (Skinner, 1986; Adams et al., 1994). Although the explosive nature of andesitic and dacitic volcanism is not as extreme as more silica-rich counterparts, examples of andesitic and dacitic tephra populations are found at Site 1124-C at 6.015 Ma and 3.342 Ma (M-46 and M-14 respectively) signifying the capability of less explosive eruptions to be preserved at greater distances from the source areas. Therefore, one would assume that as the source volcanoes were approached, the chance for ash deposits of andesitic and dacitic composition to be represented at Site 1124-C would increase. This is not seen at Site 1124-C, concluding that plate migration is not a primary control of ash distribution.

Chemical diagenetic alteration was noted in the Site 1124-C core logs of ODP Site 1124-C (see Section 1.3.3) as green silty laminae restricted to the oldest four tephra layers (M-73 to M-76) (Shipboard Scientific Party, 1999). Diagenetic alteration restricts the length of the Site 1124-C core that can be used for tephrochronologic studies; it does not, however, distort the recorded volcanic history as evidence for diagenetically altered glass is absent.

Prevailing palaeowinds are likely to have controlled the distribution of volcanic ash during the Miocene and Pliocene. Prevailing westerly winds have been noted as favouring ash dispersal to the east of the North Island during the Quaternary (1.81 Ma to present, Carter et al., 1995). This study assumes a similar wind direction prevailed throughout the Miocene and Pliocene. Allan et al. (2008) noted that eruptive events preserved as tephra layers in the Quaternary record at Site 1123 and 1124-C occurred predominantly during glacial periods, suggesting that more vigorous winds associated with glacial times assisted the eastward transport of erupted material (over potentially greater distances). Unfortunately, the orbitally tuned, benthic $\delta^{18}$ O record at Site 1123 (Hall et al., 2001) (graphically correlated to the Site 1124-C reflectance data) only extends from $0-3 \mathrm{Ma}$, preventing further testing of this hypothesis farther back into the Pliocene and Miocene. Nelson et al. (1986) note the distribution of several Miocene, Pliocene and Quaternary ash horizons in the west as a result of changing palaeowind directions and/or voluminous ash 
injection into the stratosphere beyond the westerly wind belt. This reflects the strength of large volume explosive eruptions in the CVZ, in contrast to the role played by wind direction and velocity in controlling the abundance of ash layers in deep-sea sedimentary sequences.

It can be concluded that, although plate motion, diagenetic alteration and palaeowinds may each have influenced on the distribution of volcanic ash toward Site 1124-C during the Miocene and Pliocene, the foremost control is the changing frequency of major explosive volcanism. The record is still incomplete, associated with inefficient ash transport mechanisms, the likelihood of post-depositional mixing as a result of bioturbation (see Section 1.3.4) and current-reworking during the deposition process. Conditions appear to have been reasonably favourable throughout the Miocene and Pliocene to ash deposition and preservation.

\subsubsection{Implications for Plate Tectonic Reconstructions}

This thesis reinforces the present understanding that explosive silicic volcanism from the CVZ was dominant in the late Miocene to Pliocene in the northern North Island, New Zealand. During the time of deposition of the silicic tephra layers at Site 1124-C, a convergent plate boundary was well established between the Australian and Pacific Plates, resulting in arc volcanism in response to SW dipping Hikurangi subduction zone (King, 2000).

Arc volcanism commenced $\sim 18 \mathrm{Ma}$; but the timing of abrupt change to rhyolitic volcanism in the CVZ is imprecise. Dates from onshore rhyolitic deposits indicate initiation of silicic volcanism around 10 Ma (Skinner, 1986; Adams et al., 1994). Carter et al. (2003) report an age of $12 \mathrm{Ma}$ based on the first appearance of tephra layers at Sites 1123 and 1124 ( 1.6 - 1 Myr earlier). Initiation of explosive silicic volcanism recorded at Site 1124-C is shown to have commenced no later than $\sim 9 \mathrm{Ma}$, with four alteration layers (M-73 to M-76; 9.94 to $11.16 \mathrm{Myr}$ ) potentially reflecting older rhyolitic eruptions. This study is unable to better define the initiation of explosive rhyolitic volcanism in the CVZ; however corroboration with earlier studies on a minimum age estimate of $\sim 10 \mathrm{Ma}$ is maintained. 
Major element data show that the strongest $\mathrm{K}_{2} \mathrm{O}$ enrichments (> 4.0 wt. \%) are developed in four eruptive units, M-49, M-50, M-52 and M-59, aged at 6.154 Ma, 6.264 Ma, 6.990 $\mathrm{Ma}$ and 7.280 Ma respectively (Figure 3.3). Mean $\mathrm{K}_{2} \mathrm{O}$ abundances of the four tephras range from 4.01 - 4.68 wt. \%. Intra-tephra variation is shown in Figure 4.4. The greatest degree of variation is exhibited by sample M-59; the remaining three samples are homogeneous. The inset in Figure 4.1 shows much greater homogeneity for the M-59 sample (reflecting the greater precision of trace element data).

It has been recognised that K-rich calc-alkaline magmas are (a) produced by interaction with continental lithosphere (Gill, 1981); (b) associated with the deepest part of the subduction zone (Lipman et al., 1972); or (c) a product of extension (Tarman et al., 2002). Gill (1981) suggested that $\mathrm{K}_{2} \mathrm{O}$ content was a measure of the extent of interaction with continental lithosphere in the genesis of subduction-related andesites. If this assumption can be extended to the genesis of subduction-related rhyolites, then continental crust played a significant role in the production of the high-K samples at Site 1124-C.

The geometry of the descending Pacific slab in relation to the pattern and style of volcanism in the Coromandel arc has been considered but remains unclear (Kear, 2004). King (2000, Figure 1H) suggests that the arc's inferred location near the cusp in subduction trend might be attributable to the complex Coromandel volcanism. The geographic origin of the most K-rich tephras is unknown in relation to the evolution of the Coromandel volcanic arc. Many studies have attributed the eruption of high-K magmas to incipient back-arc rifting or before appreciable extension occurs (Platt and England, 1993; Nicholson et al., 2004). The Hauraki Rift is an active continental rift that extends over 300 $\mathrm{km}$ from north of Little Barrier Island to the TVZ in the south (Hochstein et al., 1986). The age of initiation is uncertain but is considered by Hochstein and Balance (1993) to be $\sim 7 \mathrm{Ma}$. This age coincides well with the ages of the high-K samples (see above) and may provide further constraint on the timing of rift initiation in plate tectonic reconstruction. It is plausible to postulate two different scenarios: (i) crustal extension and thinning resulting in an increased heat flow from upwelling mantle; the heat generating low-degree crustal melts from high-K bearing rocks that were subsequently erupted at the surface around this time; or (ii) crustal extension thinning the crust allowing more mafic mantle melts (possibly through decompression melting or melting of basaltic underplates) to reach the surface after inducing interaction and anatexis of alkali rich crustal rocks en route. 


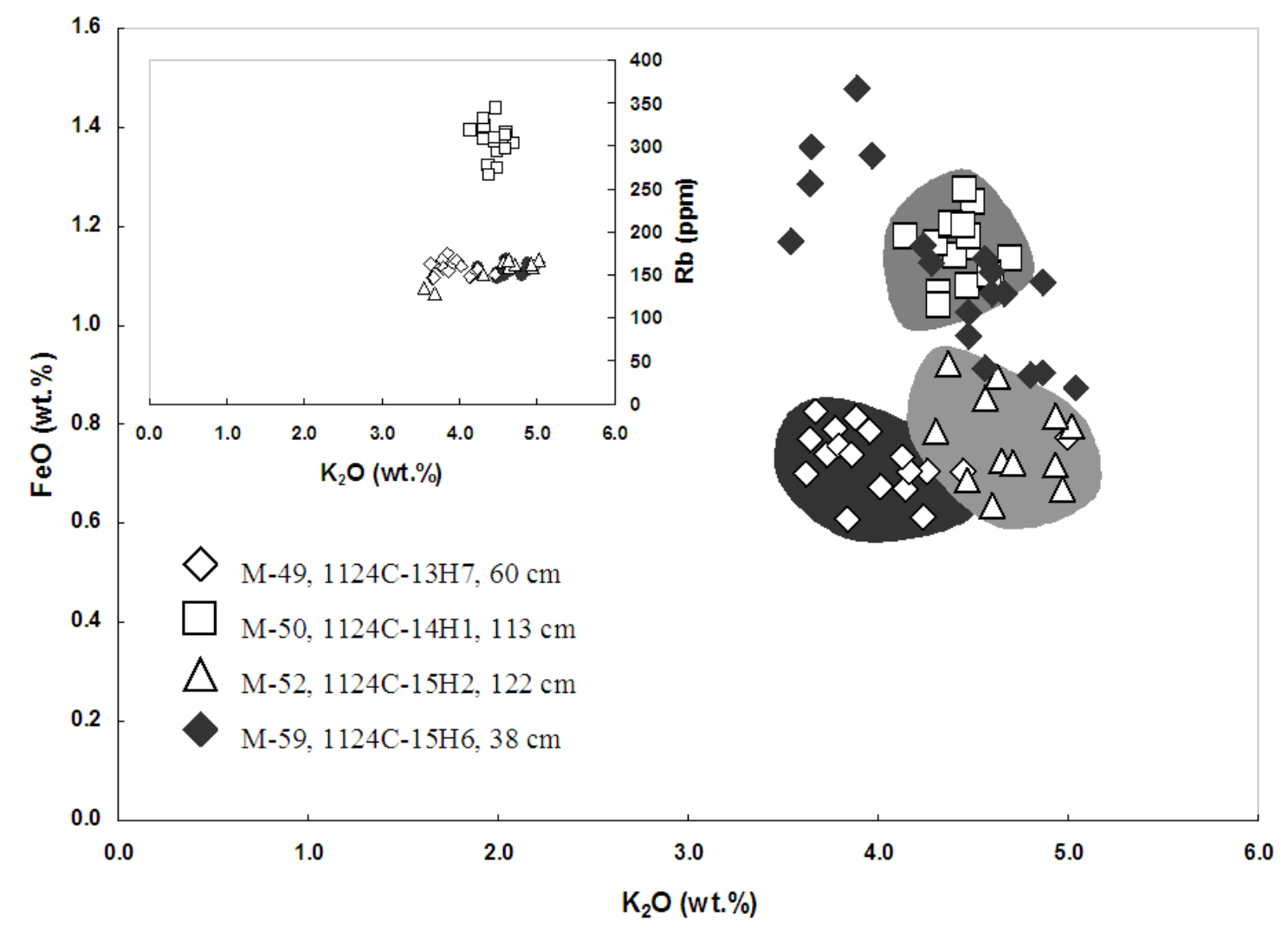

Fig. 4.4: Relationship between $\mathrm{FeO}$ and $\mathrm{K}_{2} \mathrm{O}$ (wt. \%) for the four tephras that show the strongest K enrichment, M-49, M-50, M-52 and M-59, aged at 6.154 Ma, 6.264 Ma, 6.990 $\mathrm{Ma}$ and 7.280 Ma respectively. The intra-tephra variation exhibited by each sample is highlighted by the grey fields, M-49 - dark grey, M-50 - medium grey, M-52 - light grey and $\mathrm{M}-59$ no field. Inset: $\mathrm{Rb}(\mathrm{ppm})$ and $\mathrm{K}_{2} \mathrm{O}$ (wt. \%) relationship for the same samples.

\subsubsection{CVZ-TVZ Transition}

Cenozoic subduction-related volcanism was initiated along the Coromandel Peninsula by the onset of andesitic magmatism at $\sim 18 \mathrm{Ma}$ associated with basalts and minor rhyolites (Adams et al., 1994). Early, predominantly andesite, eruptions in the CVZ gave way to major rhyolitic ignimbrite eruptions at $\sim 10 \mathrm{Ma}$ (with minor andesite and dacite eruptives) that persisted through the Pliocene. Prolonged arc volcanism was established along the Coromandel Peninsula, forming a near N-S belt that migrated southwards and eastwards in response to Pacific Plate pole rotation. Volcanism reorganised with the CVZ terminating against the NE-SW trending TVZ. TVZ volcanism was also initiated with andesitic magmatism at $\sim 2 \mathrm{Ma}$ (Wilson et al., 1995), becoming dominated by large-volume rhyolitic magmatism since $\sim 1.65 \mathrm{Ma}$ (e.g. Allan et al., 2008). The TVZ forms an actively extending continental back-arc rift that has, throughout the Quaternary, been the most 
productive site of rhyolitic volcanism in the world (Wilson et al., 1995). The CVZ remains stranded behind the active subduction system.

Previous research undertaken by Carter et al. (2004) on Sites 1123 and 1124 suggest that the transition from $\mathrm{CVZ}$ to TVZ occurred without a major hiatus in activity, with major element geochemistry of single glass shards indicating that either a continuation or overlapping interval when both the CVZ and TVZ were active is plausible. Briggs et al. (2005) conducted ${ }^{40} \mathrm{Ar} /{ }^{39} \mathrm{Ar}$ age determinations on exposed volcanic rocks from the Tauranga area and Kaimai Range, placing the transition between 1.90 and $1.60 \mathrm{Ma}$. The youngest rhyolitic tephra recovered from Site 1124-C preceding the transition is dated at 2.145 Ma. If the initiation of TVZ andesitic magmatism at $~ 2 \mathrm{Ma}$ (Wilson et al., 1995) is well constrained, then the CVZ/TVZ transition is abrupt at approximately this time.

The temporal boundary between CVZ and TVZ arc volcanism does not represent a significant time gap when placed into context of the CVZ history, where time gaps of up to $0.8 \mathrm{Myr}$ exist during the Miocene (<0.5 Myr during the Pliocene) in the marine tephra record. These intervals likely represent periods of reduced volcanism or non-preservation of tephra.

This thesis has been unable to reduce this temporal transition, which exists in the onshore record. However, previous research proposed that the CVZ/TVZ transition began much earlier between 4 - 5 Ma (e.g. Adams et al., 1994). The data acquired in this thesis may provide a means for further understanding the geochemical change in volcanism across this transition. The comparison (where available) of Site $1123 \mathrm{TVZ}$ rhyolite data fields (from Allan, 2008; Allan et al., 2008) with plots produced in this thesis show considerable overlap, with the $\mathrm{CVZ}$ data showing much greater variability. This could simply be due to the greater time span sampled by CVZ eruptive units. However, as shown earlier in Figures 3.3 and 3.9 there is a general consensus of change to less variable volcanism at $\sim 4$ Ma persisting across the CVZ/TVZ transition. Initiation of TVZ volcanism earlier than is presently thought could be considered, while more importantly suggesting that CVZ to TVZ volcanism may have occurred without significant modification to magma generation, and does not reflect abrupt change, but a more gradual continuation.

Reducing the temporal ambiguity between these two prominent rhyolitic systems in future studies may further enhance the assertion that no significant time gap exists and that the TVZ represents a geochemical and geographic continuation of the CVZ. 


\subsection{Petrogenesis of CVZ Magmas}

Arc magmas have their source in two different domains: mantle wedge and subducting slab (Bryant et al., 1999). The composition of these components and the involvement of subsequent differentiation processes have resulted in the geochemical variability recorded by CVZ Site 1124-C tephra deposits. Temporal variation in arc magmatism adds extra complication in understanding CVZ magmatic processes, particularly with respect to the significant realignment of the Pacific and Australian Plate boundary throughout the eruptive history of the CVZ.

Within the entire sample suite in this study, and more importantly, within individual tephra samples, trends in both major and trace element variation (Figures 3.4, 3.9 and 4.2) are consistent with a broad control by fractional crystallisation processes. All major element concentrations (except $\mathrm{K}_{2} \mathrm{O}$ and to a lesser extent $\mathrm{Na}_{2} \mathrm{O}$ ) show a systematic decrease with increasing $\mathrm{SiO}_{2}$ concentrations (not all shown). Trace element concentrations of $\mathrm{Ti}, \mathrm{V}, \mathrm{Sr}$, $\mathrm{Zr}$ and $\mathrm{Hf}$ reflect the fractional crystallisation of Fe-Ti oxides, titanomagnetite, feldspars and zircon. Fractional crystallisation processes exert much control on the geochemical variations within erupted magmas from the CVZ.

REE plots for the Site 1124-C tephras are also useful in helping to identify fractionating phases in the magmas as they were undergoing fractional crystallisation. Plagioclase is a common component in the fractionating assemblage of magmas. This means that plagioclase fractionation will result in a negative Eu anomaly that will become more pronounced with greater degrees of fractionation. The prominent Eu anomaly in Figure 3.7 is due to effective plagioclase crystallisation and is typical of arc magmas. For some tephra layers (e.g. M-46 (dacite population) and M-56) the negative Eu anomaly is suppressed. Upon investigation of these samples, no evidence of plagioclase enrichment was present (lack of positive co-variation between $\mathrm{Eu} / \mathrm{Eu}^{*}$ and $\mathrm{SiO}_{2}$ ). It is noted in Richards and Villeneuve (2001) that a weak Eu anomaly can occur as the result of having oxidised or hydrous arc magmas. 
Processes occurring during magma generation of the Site 1124-C tephras can also be assessed by examination of the CI chondrite-normalised REE patterns in Figure 3.7. As aforementioned, this plot shows features distinctive of evolved rhyolitic magmas. REE concentrations in the melt will increase systematically with increasing progressive differentiation, reflecting the largely incompatible behaviour of this elemental grouping. If the magmas have formed at depth $(>80 \mathrm{~km})$ as a result of partial melting of either a lowercrust or mantle source region, a residual garnet phase (in the source rock) will leave HREEs depleted in the melt owing to the high partition coefficient of HREEs in this mineral. Depletion of HREEs can also be produced if precipitation of garnet occurs in a deep-seated magma body (Rollinson, 1993). The HREE patterns for Site 1124-C tephras display a near flat line with no obvious indication of extensive HREE depletion (relative to LREEs), indicating the absence of a garnet-bearing eclogite source. This shows that the production of partial melts (if partial melting is a key process in magma generation) occurred at much shallower depths in the mantle. Alternatively, the HREE pattern of CVZ magmas described above could be explained if the magmas were contaminated by very large amounts of continental crust during melt ascent to the surface or during ponding in shallow magma chambers.

The concentration of different trace elements produced by partial melting of a source rock can assist in determination of the depth of generation of CVZ primary magmas. Phases and the abundances of such phases occurring in a source rock will strongly control trace element concentrations in the resulting partial melt. As previously concluded, a garnetbearing eclogite source has been ruled out as a potential source rock for CVZ magmas. Figure 3.8 displayed an excessive negative $\mathrm{Sr}$ anomaly normalised against primitive mantle values. Strontium is typically an incompatible element, however it is strongly fractionated in the presence of plagioclase feldspar (a major fractionating component based on a prominent negative Eu anomaly). Small degree partial melting of a plagioclase-bearing source rock at shallow depths will generate magmas that are much less enriched in $\mathrm{Sr}$. Partial melts subsequently undergo various degrees of steady-state crystal fractionation in shallow magma chambers, resulting in further Sr removal from the melt (by partitioning into plagioclase); enhancing the $\mathrm{Sr}$ depletion exhibited by $\mathrm{CVZ}$ magmas. 
"The evidence is now extremely strong that the characteristic enrichments in LILE with respect to HFSE must be explained by the fact LILE [are elements for which there is a detectable slab contribution to the source of arc volcanism] while HFSE [are elements for which there is no detectable slab contribution to the source of arc volcanism" (Pearce and Peate, 1995 p.254). HFSEs and HREEs remain immobile during slab-fluxing processes, and are derived from the mantle wedge without additional enrichments from the slab (McCulloch and Gamble, 1991). Relative depletion of HFSEs (in particular Nb) (Figure 3.8) is considered an inherent feature of the mantle wedge (Gill, 1981; McCulloch and Gamble, 1991).

Elements most effectively released in aqueous fluid from the downgoing plate transferred to the mantle wedge are LILEs and LREEs (Pearce and Peate, 1995), and Li and B (see below and next section). Lead, Th and $\mathrm{U}$ indicate slab sediment influence in the slab fluid component. HFSE concentrations cannot be altered in this manner, but they have the potential to be mobilised in more siliceous (rather than aqueous) fluids (e.g. granitic fluids) (Pearce and Peate, 1995). Higher LREE and LILE abundances (Figure 3.7 and 3.8 respectively) may reflect higher abundances in parental magmas released during low degree partial melting in the mantle source, consistent with slab fluid involvement in the melting process.

Figure 3.6 shows that HFSEs and REEs are moderately coupled at a first-order level with no distinct common control. This leads to the assertion that mantle heterogeneity or degree of partial melting controlled their concentrations in the volcanic glass. Using B/La as a measure of slab flux, assessment of the subducting Pacific Plate influence on HFSE concentrations can be considered (Figure 4.5). A negative correlation between $\mathrm{Nb} / \mathrm{Ta}$ and $\mathrm{B} / \mathrm{La}$ would be expected if increased fluid flux drives melting. Figure 4.5 displays a weak negative correlation in these elemental ratios; additional complexities may be invoked (e.g. mantle source variations and/or melting of subducted sediments), further diminishing HFSE concentrations. 


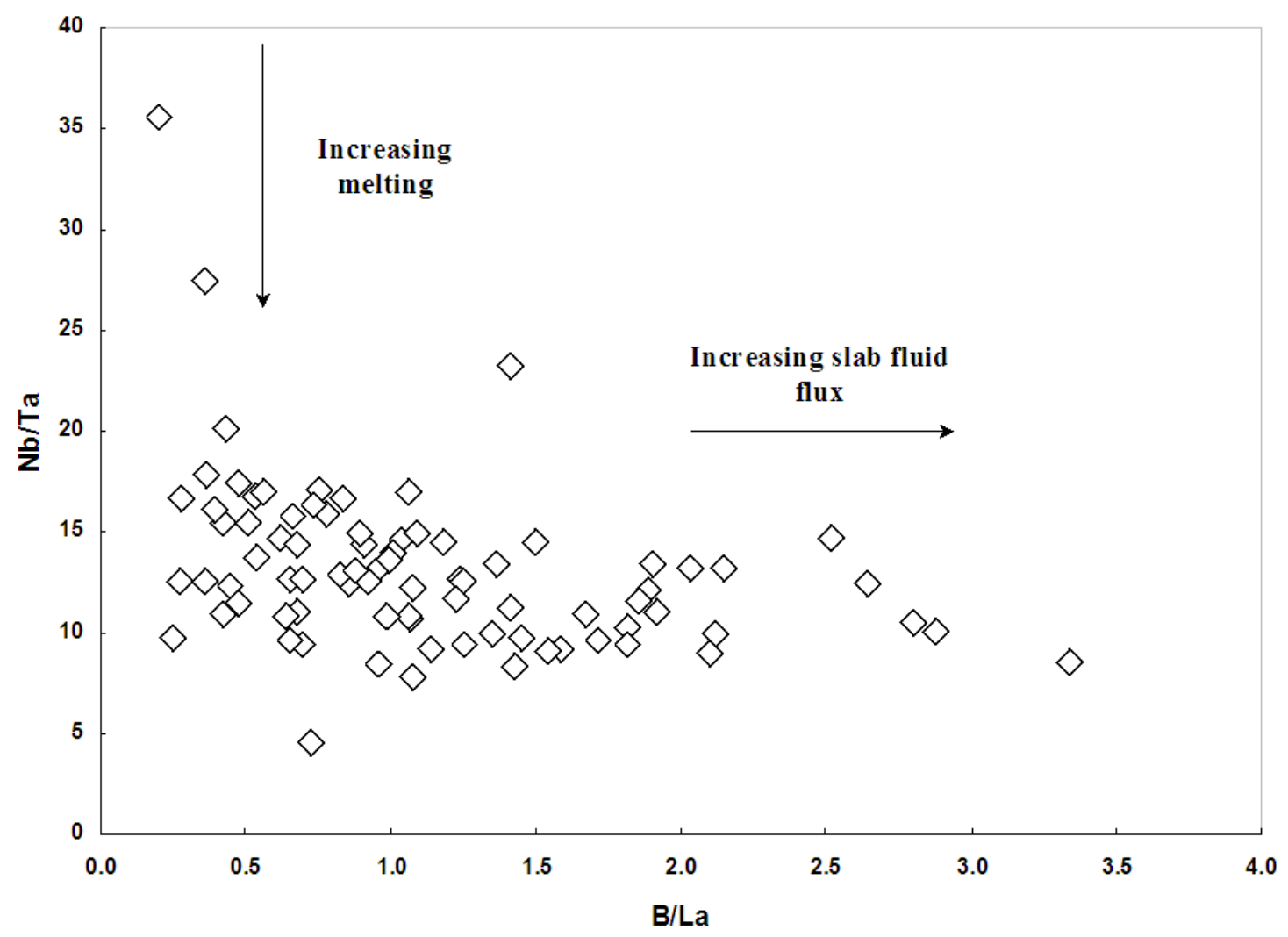

Fig 4.5: Plot of HFSE enrichment (Nb/Ta) associated with increasing melting versus increasing slab fluid flux $(\mathrm{B} / \mathrm{La})$. These elements define a weak negative correlation in mean glass shard compositions. A better defined negative correlation between $\mathrm{Nb} / \mathrm{Ta}$ and $\mathrm{B} / \mathrm{La}$ would be expected if increased fluid flux drives melting.

Temporal geochemical variation in the CVZ magmas reflects input changes to CVZ primary magmas. A simple explanation can be attributed to variation in the mantle source composition associated with variation in aqueous slab-derived fluid flux, and hence variation in slab fluid composition, resulting in variable degrees of partial melting followed by subsequent fractional crystallisation prior to eruption in shallow magma chambers. 


\subsection{Assessing the Slab-to-Mantle Transfer of Lithium and Boron}

It is well established that melting of the overlying mantle wedge is induced by the release of aqueous fluids from the descending slab through breakdown of hydrous minerals at depth (e.g. Nicholls and Ringwood, 1973; Arculus and Powell, 1986; Leeman et al., 1994; Pearce and Peate, 1995). The partitioning of trace elements between slab-derived fluids and residual phases in subducting material (e.g. McCulloch and Gamble, 1991) is recorded in the observed trace element patterns of Site 1124-C tephras, revealing a subductionrelated arc signature.

Li and B have been shown naturally (e.g. Ryan et al., 1995), and experimentally (e.g. Brenan et al., 1998), to be water-mobile elements soluble in aqueous fluids released during mineral dehydration from subducting plates. Data from subduction zone igneous and metamorphic rocks indicate efficient B removal from subducting slabs at shallow depths (e.g. Moran et al., 1992), Li may be retained in the slab to greater depths (e.g. Tomascak et al., 2000). The extent to which $\mathrm{Li}$ and $\mathrm{B}$ are transferred from descending subduction materials will have a direct influence on their abundance in the mantle wedge (Pearce and Peate, 1995; Tomascak et al., 2000); therefore, substantial Li may not reach the zone of melting beneath arcs if retained to greater depths providing a reduced arc signature from $\mathrm{Li}$ concentrations

$\mathrm{Li}$ is preferentially enriched in the sedimentary veneer of the subducting slab due to $\mathrm{Li}$ incorporation associated with weathering reactions in the presence of seawater (Chan and Kastner, 2000). This would assume that recycling of subducted sediment should provide Li to the sub-arc mantle. However, less intense Li signatures may signify offscraping and/or underplating of subducting sediments to the fore-arc. Periods of elevated $\mathrm{Li} / \mathrm{Y}$ and Li values (Section 3.2.5) may reflect dislodgement of sediments previously lost to the forearc, thus enhancing the subducted sediment signal over short intervals of CVZ eruptive history (e.g. 5.4 - 5.4 Ma) as opposed to brief periods of intensified fluid flux.

B is concentrated in both altered oceanic crust and marine sediments making B (over Li) a diagnostic tracer for assessing contribution of subducted materials to the subarc system (Leeman et al., 1994; Pearce and Peate, 1995) resulting in higher B concentrations in the mantle wedge compared to other mantle sources (Pearce and Peate, 1995). However, alternative sources for B enrichment exist, and need to be discounted. High-grade 
metamorphic magma-wall rocks have low $\mathrm{B}$ and low $\mathrm{B} / \mathrm{La}$ values, primitive mantle rocks have even lower B (Leeman et al., 1992; 1994). Therefore, contamination by such sources would result in decreases in B and B/La values in magmas (Leeman et al., 1994). The possibility that magma interacted with B-rich metasomatised mantle resulting from older subduction-related hydration and modification of mantle sources (producing elevated B and $\mathrm{B} / \mathrm{La}$ values) cannot be ruled out. This scenario has implications for high-K arc magmas recorded in Site 1124-C tephras (Section 4.2.2).

Proposed by Platt and England (1993), melts of metasomatised mantle (high-K, high-B/La and other incompatible elements) migrate into the mantle wedge where they begin to cool and solidify. Crustal extension and thinning associated with rifting in the Hauraki Rift resulted in an increased heat flow from upwelling mantle remobilising these melts that were subsequently erupted at the surface. Both the slab fluid and high-K signatures are preserved for these eruptive units; the mantle wedge signature becomes diluted. This mechanism has been employed by Stern et al. (2006) to explain the occurrence of K-rich volcanics of the western North Island, New Zealand.

$\mathrm{B}$ and $\mathrm{B} / \mathrm{La}$ values show coherent progressive enrichment through time suggesting subduction materials may have become more involved in arc magma petrogenesis as the CVZ evolved. Fluid interaction is a much more effective means of accounting for increasing $\mathrm{B} / \mathrm{La}$ at source, without significantly modifying source La-content (Leeman et al., 1994).

Melting of altered oceanic crust and/or subducted sediments, after extensive mineral breakdown and dehydration, would generate melts of a more silicic nature that are relatively poor in B (which is already mobilised to aqueous slab-derived fluids) (Leeman et al., 1994; Pearce and Peate, 1995). Low B/La ratios would be consistent with slab derived silicic melts. It is not determined if these melts would drive melting in the mantle wedge and is, therefore, not considered a mechanism to account for the chemistry of CVZ magmas recorded in Site 1124-C tephra deposits.

The addition of a small amount of subducted material and the fluid derived from it could produce magmas having a distinct subduction signature, similar to that in CVZ magmas as measured from single glass shards. Tephra layers lacking a strong slab-derived signature are more likely derived from relatively 'unfluxed' parts of the sub-arc mantle. 


\subsection{Synthesis and Conclusions}

\subsection{Project Achievements and Conclusions}

This thesis has established major and trace element geochemical fingerprints for all Site 1124-C tephras using well-established (EPMA) and new (LA-ICP-MS) in situ single glass shard microanalytical techniques. Trace element analysis of Site 1124-C glass shards (as small as $20 \mu \mathrm{m}$ ) demonstrate that trace element signatures offer a more specific, unequivocal characterisation for distinguishing (and potentially correlating) between tephras with nearly identical major element compositions

The Site 1124-C record extends the onshore CVZ eruptive sequences of explosive volcanism that are obscured by poor exposure, alteration, and erosion and burial by younger volcanic deposits. Tephra layers recovered from Site 1124 are well-dated through a combination of biostratigraphic and palaeomagnetic methods allowing the temporal geochemical evolution of the CVZ to be reconstructed in relation to changes in petrogenesis of $\mathrm{CVZ}$ arc magmas from $\sim 10$ to $2 \mathrm{Ma}$.

Major element glass shard compositions analysed for the tephras indicate they are calcalkaline, high- $\mathrm{SiO}_{2}$ rhyolites with minor dacite and andesite eruptives. Major elements imply steady-state processing during magma evolution, primarily reflecting differing degrees of fractional crystallisation during residence in the magmatic storage system. Petrogenesis cannot be unequivocally determined by major element chemistry alone.

The trace element characterisation of individual shards of volcanic glass is shown to be a very useful petrologic tool. Thus, allowing the identification of important signatures in the CVZ-derived magmas that are not clearly recognisable from the differences in the major element compositions of the same glass. These rhyolites form well-defined arrays in many major, minor and trace element plots implying that the magmas were formed through similar petrogenetic processes throughout CVZ history.

$\mathrm{CVZ}$ arc magmas are primarily influenced by the compositon of subducted materials and the subsequent transit of fluid mobile elements in slab-derived aqueous fluids into the 
mantle wedge inducing melting. The trace element behaviour of $\mathrm{Li} / \mathrm{Y}$ and $\mathrm{B} / \mathrm{La}$ shows temporal changes in the arc relating to variations in the degree of slab contribution (both sedimentary veneer and altered oceanic crust). Li/Y and B/La data have identified periods when slab flux appears to be more intensified, potentially associated with dislodgement of sediments previously offscraped and/or underplated to the forearc.

Higher LREE and LILE abundances reflect higher abundances in parental magmas released during low degree partial melting in the mantle source consistent with slab fluid involvement in the melting process.

Multi-element plots indicate that residual source phases following partial melting exhibit control on rhyolite composition. Trace element distributions show prominent negative $\mathrm{Sr}$ anomalies reflecting plagioclase fractionation. Strong negative Ti anomalies may reflect fractionation of Fe-Ti oxides (e.g. ilmenite) and titanomagnetite.

High-K magmas erupted at 7 Ma may reflect incipient back-arc rifting in the Hauraki Rift. Their geochemical character accounts for production of crustal melts due to an increasing heat flow, or melting and eruption of metasomatised mantle retaining a strong subduction signature.

Trace element characterisation of individual tephras has permitted more accurate quantitative determination of explosive eruptive episodes for the CVZ. The data presented here record 72 eruptive units corresponding to $\sim 83$ - 84 geochemical eruptive units from 9.28 - 2.145 Ma. Explosive volcanism was less intense during the Miocene (at least one per $99 \mathrm{kyr}$ ) compared to that of the Pliocene (one per 74 kyr). The Site 1124-C Miocene and Pliocene tephra record extends the signal for explosive activity for the CVZ compared to fragmentary onshore records. 


\subsection{Future Work}

The major and trace element characterisation of Miocene - Pliocene CVZ tephras accomplished in this research provides the opportunity to test its correlation potential with other tephra sequences. Correlation with nearby ODP Site 1123 is an obvious option pending major and trace element characterisation of its Miocene - Pliocene section. Furthermore, geochemical characterisation of the Quaternary section of ODP Site 1124-C may enhance present knowledge of the CVZ-TVZ transition.

The exciting prospect to correlate with onshore tephra deposits is yet to be explored successfully. The now-established LA-ICP-MS technique employed to obtain unequivocal trace element fingerprints for individual eruptive units can make this achievable. It is likely that several CVZ silicic tephras could become regional markers and their recognition is a key future objective. Further evaluation of the Site 1124-C age model and stratigraphy, and attempts at correlating to other sedimentary environments could lead to ODP Site 1124-C becoming a potential type-section for late Cenozoic tephrochronologic studies in New Zealand.

As subaerial studies along the Coromandel Peninsula progress, improved definition of large ignimbrite deposits hold considerable significance for this thesis because they indicate the likelihood of widespread airfall ash as seen at Site 1124-C. Correlation of ignimbrites with distal tephras will pinpoint caldera collapse episodes and/or constrain their eruptive histories.

Geochemical characterisation of tephras in near-shore marine sedimentary sequences that have captured and preserved both large explosive and smaller effusive tephra-generating eruptions will further refine our view of CVZ extinction - TVZ initiation, currently viewed as $\sim 2 \mathrm{Ma}$ and $\sim 1.65 \mathrm{Ma}$ respectively. Reducing the temporal ambiguity between these two prominent rhyolitic systems may further enhance the assertion that no significant time gap exists, and that the TVZ represents a geochemical and geographic continuation of the CVZ.

Beryllium (Be) is an incompatible element that has similar compatibility in igneous phases to B. Coupling these two elements together would provide a diagnostic ratio between elements with relatively identical mineral-melt partition coefficients that is not disturbed 
by fractional crystallisation or partial melting processes (Clift et al., 2005). B/Be ratios are controlled by slab contribution to the mantle source of arc magmas. Therefore, $\mathrm{B} / \mathrm{Be}$ may be a useful indicator of the amount of slab-derived B in arc magmas. The addition of Be to the inventory of trace elements analysed in single glass shards, may be a more definitive signature of subducted materials when no other data is available.

Most trace element and isotopic data used to examine the petrogenesis of TVZ volcanic rocks, are rare or absent for CVZ volcanic rocks. Isotopic methods are useful because they are generally not susceptible to influence by partial melting or crystal fractionation processes (Tomascak et al., 1999). Site 1124-C tephras are $~ 720 \mathrm{~km}$ from the extinct Coromandel arc, their large distance from source means they consist of $>90 \%$ volcanic glass shards with the remainder comprising igneous minerals and non-volcanic detritus of varying proportions. Any tephras recovered from Site 1124-C selected for isotopic analysis would be chosen to ensure that the amounts of non-volcanic glass were so minimal so as to reduce any effect on the isotopic composition. In particular, the influence of sediment contribution to the subduction component can be more accurately established using isotopic tracers. ${ }^{10} \mathrm{Be} /{ }^{9} \mathrm{Be}$ systematics are controlled by sub-arc mantle processes and are consequently becoming commonplace for monitoring subduction zone contribution. ${ }^{10} \mathrm{Be} /{ }^{9} \mathrm{Be}$ ratios from Site $1124-\mathrm{C}$ tephras with elevated and depleted B/La (and/or Li/Y) values, will establish how effective B (and potentially Li) are as effective tracers of slab fluid involvement in arc petrogenesis as well as confirming a common source for ${ }^{10} \mathrm{Be}$ and $\mathrm{B}$ in altered oceanic crust. 


\subsection{References}

Adams, C.J., Graham, I.J., Seward, D., Skinner, D.N.B., 1994. Geochronological and geochemical evolution of late Cenozoic volcanism in the Coromandel Peninsuala, New Zealand. New Zealand Journal of Geology and Geophysics 37, 359-379.

Allan, A.S.R., 2008. An elemental and isotopic investigation of Quaternary silicic Taupo Volcanic Zone tephras from ODP Site 1123: chronostratigraphic and petrogenetic applications. Unpublished MSc thesis lodged at the Library, Victoria University of Wellington.

Allan, A.S.R., Baker, J.A., Carter, L., Wysoczanski, R.J., 2008. Reconstructing the Quaternary evolution of the world's most active silicic volcanic system: insight from an $~ 1.65$ Ma deep ocean tephra record sourced from Taupo Volcanic Zone, New Zealand. Quaternary Science Reviews 27, 2341-2360.

Alloway, B.V., Pillans, B.J., Sandhu, A.S., Westgate, J.A., 1993. Revision of the marine chronology in the Wanganui Basin, New Zealand, based on the isothermal plateau fission-track dating of tephra horizons. Sedimentary Geology 82, 299-310.

Alloway, B.V., Westgate, J.A., Pillans, B., Pearce, N., Newnham, R.M., Byrami, M., Aarburg, S., 2004. Stratigraphy, age and correlation of middle Pleistocene silicic tephras in the Auckland region, New Zealand; a prolific distal record of Taupo volcanic zone volcanism. New Zealand Journal of Geology and Geophysics 47, 447-479.

Alloway, B.V., Pillans, B.J., Naish, T.R., Westgate, J.A., 2005. Onshore-offshore correlation of Pleistocene rhyolitic eruptions from New Zealand: implications for TVZ eruptive history and paleoenvironmental construction. Quaternary Science Reviews 24, 1601-1622.

Alloway, B.V., Larsen, G., Lowe, D.J., Shane, P.A.R., Westgate, J.A., 2007. Tephrochronology. Encyclopaedia of Quaternary Science (ed. S.A Elias), Elsevier, London, pp. 2869-2898. 
Arculus, R.J., Powell, R., 1986. Source component mixing in the regions of arc magma generation. Journal of Geophysical Research 91, 5913-5926.

Aston, B.C., 1926. A reconnaisance survey of pumice soils, Rotorua County. IV. New Zealand Journal of Agriculture 32, 365-374.

Aston, B.C., 1927. A reconnaisance survey of pumice soils, Rotorua County. V. New Zealand Journal of Agriculture 35, 96-100.

Baker, M.C.W., Francis, P.W., 1978. Upper Cenozoic volcanism in the Central Andes ages and volumes. Earth and Planetary Science Letters 41, 175-187.

Berggren, W.A., Hilgen, F.J., Langereis, C.G., Kent, D.V., Obradovich, J.D., Raffi, I., Raymo, M.E., Shackleton, N.J., 1995. Late Neogene chronology: New Perspective in high-resolution stratigraphy. Geological Society of America Bulletin 107, 12721287.

Brenan, J.M., Ryerson, F.J., Shaw, H.F., 1998. The role of aqueous fluids in the slab-tomantle transfer of boron, beryllium, and lithium during subduction: Experiments and models. Geochimica et Cosmochimica Acta 62, 3337-3347.

Briggs, R.M., Fulton, B.W.J., 1990. Volcanism, structure, and petrology of the WhiritoaWhangamata coastal section, Coromandel Volcanic Zone, New Zealand: facies model evidence for the Tunaiti caldera. New Zealand Journal of Geology and Geophysics 33, 623-633.

Briggs, R.M., Houghton, B.F., McWilliams, M., Wilson, C.J.N., 2005. ${ }^{40} \mathrm{Ar} /{ }^{39} \mathrm{Ar}$ age of silicic volcanic rocks in the Tauranga-Kaimai area, New Zealand: dating the transition between volcanism in the Coromandel Arc and the Taupo Valcanic Zone. New Zealand Jounral of Geology and Geophysics 48, 459-469.

Bryant, C., Arculus, R., Eggins, S., 1999. Laser ablation-inductively coupled plasma-mass spectrometry and tephras: A new approach to understanding arc-magma genesis. Geology 27, 1119-1122. 
Cande, S.C., Kent, D.V., 1995. Revised calibration of the geomagnetic polarity timescale for the Late Cretaceous and Cenozoic. Journal of Geophysical Research 100, 60936095.

Carter, L., McCave, I.N., 1994. Development of sediment drifts approaching an active plate margin under the S.W. Pacific deep western boundary current. Paleoceanography 9, 1061-1085.

Carter, L., Nelson, C.S., Neil, H.L., Froggatt, P.C., 1995. Correlation, dispersal, and preservation of the Kawakawa Tephra and other late Quaternary tephra layers in the Southwest Pacific Ocean. New Zealand Journal of Geology and Geophysics 38, 2946.

Carter, L., Shane, P., Alloway, B., Hall, I.R., Harris, S.E., Westgate, J.A., 2003. Demise of one volcanic zone and birth of another - A 12 m.y. marine record of major rhyolitic eruptions from New Zealand. Geology 31, 493-496.

Carter, L., Alloway, B., Shane, P., Westgate, J., 2004. Deep-ocean record of major late Cenozoic rhyolitic eruptions from New Zealand. New Zealand Journal of Geology and Geophysics 47, 481-500.

Chan, L.H., Kastner, M., 2000. Lithium isotopic compositions of pore fluids and sediments in the Costa Rica subduction zone: implications for fluid processes and sediment contribution to the arc volcanoes. Earth and Planetary Science Letters 183, 275290.

Clift, P.D., Chan, L., Blusztajn, J., Layne, G.D., Kastner, M., Kelly, R.K., 2005. Pulsed subduction accretion and tectonic erosion reconstructed since $2.5 \mathrm{Ma}$ from the tephra record offshore Costa Rica. Geochemistry, Geophysics, Geosystems 6, Q09016, doi:10.1029/2005GC000963.

Cole, J.W., 1986, Distribution and tectonic setting of late Cenozoic volcanism in New Zealand. In: Smith, I.E.M. ed Late Cenozoic volcanism in New Zealand. Royal Society of New Zealand bulletin 23, 7-20. 
Cusson, L., 1888. Notes on the physiography and geology of the King Country. Transactions of the New Zealand Institute 20, 316-332.

Eggins, S.M., Kinsley, L.P.J., Shelley, J.M.G., 1998. Deposition and element fractionation processes during atmospheric pressure laser sampling for analysis by ICP-MS. Applied Surface Science 129, 278-286.

Elliot, T., Plank, T., Zindler, A., White, W.M., Bourdon, B., 1997. Element transport from the slab to volcanic front at the Mariana arc. Journal of Geophysical Research 102, $14,991-15,019$.

Fisher, R.V., Schmincke, H.U., 1984. Pyroclastic Rocks. Springer-Verlag, BerlinHeidelberg, Germany, 472 pp.

Froggatt, P.C., 1983. Toward a comprehensive upper Quaternary tephra and ignimbrite stratigraphy in New Zealand using electron microprobe analysis of glass shards. Quaternary Research 19, 188-200.

Froggatt, P.C., Lowe, D.J., 1990. A review of late Quaternary silicic and some other tephra formations from New Zealand: their stratigraphy, nomenclature, distribution, volume, and age. New Zealand Journal of Geology and Geophysics 33, 89-109.

Gill, J.B., 1981. Orogenic Andesites and Plate Tectonics. Springer-Verlag, Berlin, Germany, $401 \mathrm{pp}$.

Gosson, G.J., 1986. Miocene and Pliocene silicic tuffs in marine sediments of the East Coast Basin, New Zealand. Unpublished MSc. thesis lodged in the Library, Victoria University of Wellington.

Guillong, M., 2004. Laser Ablation Inductively Coupled Plasma Mass Spectrometry: Laser ablation system developments and investigations on elemental fractionation. A dissertation submitted to the Eidgenossischen Technischen Hochschule Zurich.

Hall, I.R., McCave, I.N., Shackleton, N.J., Weedon, G.P., Harris, S.E. 2001. Intensified deep Pacific inflow and ventilation in Pleistocene glacial times. Nature 412, 809812. 
Harangi, S., Mason, P., Lukacs, R., 2005. Correlation and Petrogenesis of silicic pyroclastic rocks in the Northern Pannonian Basin, Eastern-Central Europe: In situ trace element data of glass shards and mineral chemical constraints. Journal of Volcanology and Geothermal Research 143, 237-257.

Healy, J., 1964. Stratigraphy and chronology of late Quaternary volcanic ash in Taupo, Rotorua, and Gisborne districts. Part 1. Dating of the younger volcanic eruptions of the Taupo region. N.Z. Geological Survey Bulletin 73, 7-42.

Hildreth, W., 1981. Gradients in silicic magma chambers: implications for lithospheric magmatism. Journal of Geophysical Research 86, 10153-10192.

Hochstein, M.P., Tearney, K., Rawson, K., Davey, F.J., Davidge, S., Henrys, S., Backshall, D., 1986. Structure of the Hauraki Rift (New Zealand). Royal Society of New Zealand Bulletin 24, 333-348.

Hochstein, M.P., Ballance, P.F., 1993. Hauraki Rift: a young, active, intra-continental rift in a back-arc setting, in Ballance, P.F. ed. South Pacific sedimentary basins. Elsevier, Amsterdam. p. 295-305.

Hogg, A.G., Higham, T.F.G., Lowe, D.J., Palmer, J., Reimer, P., Newnham, R.M., 2003. A wiggle-match date for Polynesian settlement of New Zealand. Antiquity 77, 116125.

Houghton, B.F., Wilson, C.J.N., McWilliams, M.O., Lanphere, M.A., Weaver, S.D., Briggs, R.M., Pringle, M.S., 1995. Chronology and dynamics of a large silicic magmatic system: Central Taupo Volcanic Zone, New Zealand. Geology 23, 13-16.

Howorth, R., Rankin, P.C., 1975. Multi-element characterisation of glass shards from stratigraphically correlated rhyolitic tephra units. Chemical Geology 15, 239-250.

Hunt, J.B., Hill, P.G., 2001. Tephrological implications of beam size - sample-size effects in electron microprobe analysis of glass shards. Journal of Quaternary Science, 16, 105-117. 
Jarosewich, E., Nelen, J.A., Norberg, J.A., 1979. Electron microprobe reference samples for mineral analysis. Smithsonian Contributions to the Earth Sciences 22, 68-72.

Jochum, K.P., Stoll, B., Herwig, K., Willbold, W., Hofmann, A.W., Amini, M., Aarburg, S., Abouchami, W., Hellebrand, E., Mocek, B., Raczek, I., Stracke, A., Alard, O., Bouman, C., Becker, S., Dücking, M., Brätz, H., Klemd, R., de Bruin, D., Canil, D., Cornell, D., de Hoog, C.J., Dalpé, C., Danyushevsky, L., Eisenhauer, A., Gao, Y., Snow, J.E., Groschopf, N., Günther, D., Latkocsy, C., Guillong, M., Hauri, E.H., Höfer, H,E., Lahaye, Y., Horz, K., Jacob, D.E., Kasemann, S.A., Kent, A.J.R., Ludwig, T., Zack, T., Mason, P.R.D., Meixner, A., Rosner, M., Misawa, K., Nash, B.P., Pfänder, J., Premo, W.R., Sun, W.D., Tiepolo, M., Vannucci, R., Vennemann, T., Wayne, D., Woodhead, J.D., 2006. MPI-DING reference glasses for in situ microanalysis: New reference values for element concentrations and isotope ratios. Geochemistry Geophysics Geosystems 7, Q02008, doi:10.1029/2005GC001060.

Joseph, L.H., Rea, D.K., van der Pluijm, B.A. 2004. Neogene history of the Deep Western Boundary Current at Rekohu sediment drift, Southwest Pacific (ODP Site 1124). Marine Geology 205, 185-206.

Kear, D., 1994. A "least complex" dynamic model for late Cenozoic volcanism in the North Island, New Zealand. New Zealand Journal of Geology and Geophysics 37, 223-236.

Kear, D., 2004. Reassessment of Neogene tectonism and volcanism in North Island, New Zealand. New Zealand Journal of Geology and Geophysics 47, 361-374.

Kennett, J.P., 1981. Marine Tephrochronology, In Emiliani, C., ed. The Sea. Vol. 7. New York, John Wiley. 1373-1436.

King, P., 2000. Tectonic reconstructions of New Zealand: 40 Ma to the Present. New Zealand Journal of Geology and Geophysics 43, 611-638.

Kuhn, H.R., Guillong, M., Gunther, D., 2004. Size-related vapourisation and ionisation of laser-induced glass particles in the inductively coupled plasma. Analytical and Bioanalytical Chemistry 378, 1069-1074. 
Kuhn, H.R., Gunther, D., 2004. Laser ablation-ICP-MS: particle size dependent elemental composition studies on filter-collected and online measured aerosols from glass. Journal of Analytical Atomic Spectrometry 19, 1158-1164.

Le Bas, M.J., Le Maitre, R.W., Streckeisen, A., Zanettin, B., 1986. A chemical classification of volcanic rocks based on the total alkali-silica diagram. Journal of Petrology 27, 745-750.

Le Maitre, R.W., 1984. A proposal by the IUGS subcommission on the systematics of igneous rocks for a chemical classification of volcanic rocks based on total alkali silica (TAS) diagram. Australian Journal of Earth Sciences 31, 243-255.

Ledbetter, M.T., 1985. Tephrochronology of marine tephra adjacent to Central America. Geological Society of America Bulletin 96, 77-82.

Ledbetter, M.T., Sparks, R.S.J., 1979. Duration of large-magnitude explosive eruptions deduced from graded bedding in deep-sea ash layers. Geology 7, 240-244.

Leeman, W.P., Sisson, V.B., Reid, M.R., 1992. Boron geochemistry of the lower crust: Evidence from granulite terranes and deep crustal xenoliths. Geochimica et Cosmochimica Acta 56, 775-788.

Leeman, W.P., Carr, M.J., Morris, J.D., 1994. Boron geochemistry of the Central American Volcanic Arc: Constraints on the genesis of subduction-related magmas. Geochimica et Cosmochimica Acta 58, 149-168.

Lipman, P.W., Prostka, H.J., Christiansen, R.L., 1972. Cenozoic volcanism and platetectonic evolution of the western United States: I. Early and middle Cenozoic. Philosophical Transactions of the Royal Society of London A 271, 217-248.

Lisitzin, A.P., 1972. Sedimentation in the world ocean. Society of Economic Paleontologists and Mineralogists Special Publication 17, 1-208. 
Longerich, H., Diegor, W., 2001. Introduction to mass spectrometry, In Laser-AblationICP-MS in the Earth sciences, Short Course Series 29, ed. Sylvestor, P., Mineralogical Association of Canada, pp. 243.

Lowe, D.J., 1990. Tephra studies in New Zealand: an historical review. Journal of the Royal Society of New Zealand 20, 119-49.

Malengreau, B., Skinner, D., Bromley, C., Black, P., 2000. Geophysical characterisation of large silicic volcanic structures in the Coromandel Peninsula, New Zealand. New Zealand Journal of Geology and Geophysics 43, 171-186.

Manville, V., Wilson, C.J.N., 2004. Vertical density currents: a review of their potential role in the deposition and interpretation of deep-sea ash layers. Journal of the Geological Society, London 161, 947-958.

McCulloch, M.T., Gamble, J.A., 1991. Geochemical and geodynamical constraints on subduction zone magmatism. Earth and Planetary Science Letters 102, 358-374.

McMillan, N.J., Davidson, J.P., Worner, G., Harmon, R.S., Moorbath, S., Lopez-Esobar, S., 1993. Influence of crustal thickening on arc magmatism: Nevados de Payachata volcanic region, northern Chile. Geology 21, 467-470.

Moran, A.E., Sisson, V.B., Leeman, W.P., 1992. Boron depletion during progressive metamorphism: Implications for subduction processes: Earth and Planetary Science Letters 111, 331-349.

Naish, T., Kamp, P.J.J., Alloway, B.V., Pillans, B., Wilson, G.S., Westgate, J.A., 1996. Integrated tephrochronology and magnetostratigraphy for cyclothemic marine strata, Wanganui Basin: Implications for the Pliocene-Pleistocene boundary in New Zealand. Quaternary International 34-36, 29-48.

Nelson, C.S., Froggatt, P.C., Gossan, G.J., 1986. Nature, chemistry, and origin of Late Cenozoic megascopic tephras in Leg 90 cores from the Southwest Pacific. Initial Reports of Deep Sea Drilling Project, Volume XC, Part 2, 1161-1171. 
Nicholls, I.A., Ringwood, A.E., 1973. Effects of water on olivine stability in tholeiites and the production of silica-saturated magmas in the island-arc environment. Journal of Geology 81, 285-300.

Nicholson, K.N., Black, P.M., Hoskin, P.W.O., Smith, I.E.M., 2004. Silicic volcanism and back-arc extension related to migration of the Late Cainozoic Australian-Pacific plate boundary. Journal of Volcanology and Geothermal Research 131, 295-306.

Nielson, C.H., Sigurdsson, H., 1981. Quantitative methods for electron microprobe analysis of sodium in natural and synthetic glasses. American Mineralogist, 66, 547-552.

Palme, H., Beer, H., 1993. Abundances of the elements in the Solar System, In Landolt Bornstien, Astronomy and Astrophysics (ed. H.H. Voigt); extension and supplementary to Vol. 2, Sub Vol. A. Springer, Berlin, Germany, pp. 196-221.

Pearce, J.A., Peate, D.W., 1995. Tectonic implications of the composition of volcanic arc magmas. Annual Reviews Earth and Planetary Science 23, 251-285.

Pearce, N., Westgate, J., Perkins, W., 1996. Developments in the analysis of volcanic glass shards by laser ablation ICP-MS: Quantitative and single internal standard-multielement methods. Quaternary International 34-36, 213-227.

Pearce, N., Westgate, J., Perkins, W., Eastwood, W., Shane, P., 1999. The application of laser ablation ICP-MS to the analysis of volcanic glass shards from tephra deposits: bulk glass and single glass shard analysis. Global and Planetary Change 21, 151171.

Pearce, N., Eastwood, W., Westgate, J., Perkins, W., 2002. Trace element composition of single glass shards in distal Minoan tephra from SW Turkey. Journal of the Geological Society, London 159, 545-556.

Pearce, N., Westgate, J., Perkins, W., Preece, S., 2004. The application of ICP-MS methods to tephrochronological problems. Applied Geochemistry 19, 289-322. 
Pearce, N., Denton, J., Perkins, W., Westgate, J., Alloway B., 2007. Correlation and characterisation of individual glass shards from tephra deposits using trace element laser ablation ICP-MS analyses: current status and future potential. Journal of Quaternary Science 22, 721-736.

Pearce, N., Westgate, J., Alloway, B., 2008. Mid-Pleistocene silicic tephra beds in the Auckland region, New Zealand.: their correlation and origins based on trace element analyses of single shards. Quaternary International 178, 16-43.

Platt, J.P., England, P.C., 1993. Convective removal of lithosphere beneath mountain belts: Thermal and mechanical consequences. American Journal of Science 293, 307-336.

Potts, P.J., Tindle, A.G., Isaacs, M.C., 1983. On the precision of electron microprobe data: a new test for the homogeneity of mineral standards. American Mineralogist, 68, 1237-1242.

Richards, J.P., Villeneuve, M., 2001. The Llullaillaco volcano, northwest Argentina: construction by Pleistocene volcanism and destruction by sector collapse. Journal of Volcanology and Geothermal Research 105, 77-105.

Rollinson, H.R., 1993. Using geochemical data, evaluation, presentation, interpretation: London, Pearson/Prentice Hall.

Ryan, J.G., Langmuir, C.H., 1987. The systematics of lithium abundances in young volcanic rocks. Geochimica et Cosmochimica Acta 51, 1727-1741.

Ryan, J.G., Morris, J.D., Tera, F., Leeman, W.P., Tsvetkov, A., 1995. Cross-arc geochemical variations in the Kurile arc as a function of slab depth. Science 270, 625-627.

Sano, T., Hasenaka, T., Shimaoka, A., Yonezawa, C., Fukuoka, T., 2001. Boron contents of Japan Trench sediments and Iwate basaltic lavas, Northeast Japan arc: estimation of sediment-derived fluid contribution in mantle wedge. Earth and Planetary Science Letters 186, 187-198. 
Self, S., Sparks, R.S.J., 1978. Characteristics of widespread pyroclastic deposits formed by the interaction of silicic magma and water. Bulletin Volcanologique 41, 196-212.

Shane, P.A.R., 1990. Correlation of some Pliocene tuffs in Southern Wairarapa, New Zealand, and comparison with biostratigraphic and magnetostratigraphic data. New Zealand Journal of Geology and Geophysics 33, 349-354.

Shane, P., 2000. Tephrochronology: a New Zealand case study. Earth-Science Reviews 49, 223-259.

Shane, P., Froggatt, P., Black, T., Westgate, J., 1995. Chronology of Pliocene and Quaternary bioevents and climatic events from fission-track ages on tephra beds, Wairarapa, New Zealand. Earth and Planetary Science Letters 130, 141-154.

Shane, P., Black, T., Eggins, S., Westgate, J., 1998. Late Miocene marine tephra beds: recorders of rhyolitic volcanism in North Island, New Zealand. New Zealand Journal of Geology and Geophysics 41, 165-178.

Shane, P., Nairn, I.A., Martin, S.B., Smith, V.C., 2008. Compositional heterogeneity in tephra deposits resulting from the eruption of multiple magma bodies: Implications for tephrochronology. Quaternary International 178, 44-53.

Shipboard Scientific Party, 1999. Site 1124: Rekohu Drift - from the K/T boundary to the Deep Western Boundary Current. Proceedings of the Ocean Drilling Program Initial Report Leg 181, 1-137 (CD-ROM).

Sigurdsson, H., Sparks, R.S.J., Carey, S.N., Huang, T.C., 1980. Volcanogenic sedimentation in the Lesser Antilles arc. Journal of Geology 88, 523-540.

Skinner, D.N.B., 1986. Neogene volcanism of the Hauraki Volcanic Region. In: Smith, I.E.M. ed Late Cenozoic volcanism in New Zealand. Royal Society of New Zealand bulletin 23, 21-47.

Smith, D.G.W., Westgate, J.A., 1969. Electron probe technique for characterising pyroclastic deposits. Earth and Planetary Science Letters, 5, 313-319. 
Smith, D.G.W., Westgate, J.A., Tomlinson, M.C., 1969. Characterisation of pyroclastic units - a stratigraphic application of the microprobe. Electron Probe Analysis Society of America, Fourth National Conference on electron microprobe analysis, Proceedings, Pasadena, California, unpaginated.

Smith, N., Cassidy, J., Locke, C.A., Mauk, J.L., Christie, A.B., 2006. The role of regionalscale faults in controlling a trapdoor caldera, Coromandel Peninsula, New Zealand. Journal of Volcanology and Geothermal Research 149, 312-328.

Sparks, R.S.J., 1978. The dynamics of bubble formation and growth in magmas: a review and analysis. Journal of Volcanology and Geothermal Research 3, 1-37.

Sparks, R.S.J., Wilson, L., Hulme, G., 1978. Theoretical modelling of the generation, movement, and emplacement of pyroclastic flows by column collapse. Journal of Geophysical Research 83, 1727-1738.

Sparks, R.S.J., Bursik, M.I., Carey, S.N., Gilbert, J.S., Glaze, L.S., Sigurdsson, H., Woods, A.W., 1997. Volcanic Plumes. John Wiley and Sons Ltd, England. Pages 574.

Stern, T.A., Stratford, W.R., Salmon, M.L., 2006. Subduction evolution and mantle dynamics at a continental margin: central North Island, New Zealand. Reviews of Geophysics 44, RG4002, doi:10.1029/2005RG000171.

Sun, S.S., McDonough, W.F., 1989. Chemical and isotopic systematics of oceanic basalts: implications for mantle composition and processes, in: Saunders, A.D., Norry, M.J., eds. Magmatism in the Oceanic Basins. Geological Society of London Special Publications 42, 313-345.

Sweatman, T.R., Long, J.V.P., 1969. Quantitative electron-probe microanalysis of rockforming minerals. Journal of Petrology 10, 332-379.

Takagi, M., 1995. Miocene-Pliocene arc volcanism of the Hauraki region in North Island, New Zealand. Unpublished MSc. Thesis, Okayama University of Science, Okayama, Japan. 
Tarman, D.W., Jessey, D.R., Beal, J.K., Baltzer, S.M., 2002. Petrochemistry and geochronology of the Mesquite Pass sill, San Bernardino County, California. Geological Society of America Abstracts Volume 34, Corvallis, Oregon.

Tomascak, P.B., Tera, F., Helz, R.T., Walker, R.J., 1999. The absence of lithium isotope fractionation during basalt differentiation: New measurement by multi-collector sector ICP-MS. Geochimica et Cosmochimica Acta 63, 907-910.

Tomascak, P.B., Ryan, J.G., Defant, M.J., 2000. Lithium isotope evidence for light element decoupling in the Panama subarc mantle. Geology 28, 507-510.

Vucetich, C.G., Pullar, W.A., 1964. Stratigraphy and chronology of late Quaternary volcanic ash in Taupo, Rotorua, and Gisborne districts. Part 2. Stratigraphy of Holocene ash in the Rotorua and Gisborne districts. N.Z. Geological Survey Bulletin 73, 43-78.

Walker, G.P.L., 1979. A volcanic ash generated by explosions where ignimbrite entered the sea. Nature 281, 642-646.

Walker, G.P.L., 1980. The Taupo Pumice: product of the most powerful known (ultraplinian) eruption? Journal of Volcanology and Geothermal Research 8, 69-94.

Weedon, G.P., Hall, I.R., 2004. Neogene palaeoceanography of Chatham Rise (Southwest Pacific) based on sediment geochemistry. Marine Geology 205, 207-225.

Westgate, J., Perkins, W., Fuge, R., Pearce, N., Wintle, A., 1994. Trace element analysis of volcanic glass shards by laser ablation inductively coupled plasma mass spectrometry: application to Quaternary tephrochronological studies. Applied Geochemistry 9, 323-355.

Wilson, C.J.N., Houghton, B.F., McWillams, M.O., Lanphere, M.A., Weaver, S.D., Briggs, R.M., 1995. Volcanic and structural evolution of Taupo Volcanic Zone, New Zealand: a review. Journal of Volcanology and Geothermal Research 68, 128. 


\section{Appendix One}

\section{Sample List}

Table A1. Sample list from ODP Site 1124-C. 
Base of

Ash Thicknes of Biostrat. Pal. Mag

MS - \#'s AT - \#'s Leg Hole Core Type Section ash (cm) mbsf

Comments

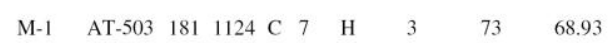

$5 Y 7 / 1$

5 Y $5 / 1$ (base) to 5 Y $7 / 1$ (top)

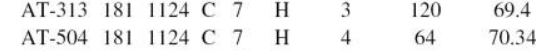

$\begin{array}{llllllllll}\text { AT-326 } & 181 & 1124 & \mathrm{C} & 7 & \mathrm{H} & 4 & 90 & 70.6\end{array}$

$\begin{array}{lllllllll}\text { M-5 } & 181 & 1124 & \mathrm{C} & 7 & \mathrm{H} & 5 & 19 & 71.39\end{array}$

$\begin{array}{llllllllllll}\text { M-6 } & 181 & 1124 & \mathrm{C} & 7 & \mathrm{H} & 5\end{array}$

$\begin{array}{llllll}\text { M-7 } & 181 & 1124 & \text { C } & 7 & \text { H } \\ \text { M-8 } & 181 & 1124 & \text { C } & 7 & \text { H }\end{array}$

$\begin{array}{clllll}\text { M-8 } & 181 & 1124 & \mathrm{C} & 7 & \mathrm{H} \\ \text { M-9 } & 181 & 1124 & \mathrm{C} & 8 & \mathrm{H} \\ \text { M-10 } & 181 & 1124 & \mathrm{C} & 8 & \mathrm{H}\end{array}$

$\begin{array}{lrlllll}\text { M-11 } & & 181 & 1124 & \mathrm{C} & 9 & \mathrm{H} \\ \mathrm{M}-12 & \text { AT-252 } & 181 & 1124 & \mathrm{C} & 9 & \mathrm{H}\end{array}$

$\begin{array}{lrlllll}\text { M-12 } & \text { AT-252 } & 181 & 1124 & \mathrm{C} & 9 & \mathrm{H} \\ \mathrm{M}-13 & & 181 & 1124 & \mathrm{C} & 9 & \mathrm{H}\end{array}$

M-14 $181 \quad 1124$ C $99 \mathrm{H}$

$\begin{array}{llllll}\text { M-15 } & 181 & 1124 & \mathrm{C} & 9 & \mathrm{H}\end{array}$

M-16 AT-262 $181 \quad 1124 \quad \mathrm{C} 9 \quad \mathrm{H}$

$\begin{array}{llllll}\mathrm{M}-17 & 181 & 1124 & \mathrm{C} & 9\end{array}$

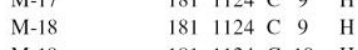

M-19 $181 \quad 1124 \quad \mathrm{C} \quad 10 \quad \mathrm{H}$

$\begin{array}{lllllllllllll}\text { M-20 } & 181 & 1124 & \mathrm{C} & 10 & \mathrm{H}\end{array}$

M-21 $181 \quad 1124 \quad \mathrm{C} \quad 10$

$\begin{array}{lllllll}\text { M-22 } & 181 & 1124 & \mathrm{C} & 10 & \mathrm{H}\end{array}$

$\begin{array}{llllll}M-23 & 181 & 1124 & \mathrm{C} & 10 & \mathrm{H} \\ \mathrm{M} & 181 & 1124 & \mathrm{C} & 10 & \mathrm{H}\end{array}$

$\begin{array}{lllllllllllllll}M-25 & 181 & 1124 & \mathrm{C} & 10 & \mathrm{H}\end{array}$

$\begin{array}{lllllll}\text { M-26 } & 181 & 1124 & \mathrm{C} & 10 & \mathrm{H}\end{array}$

$\begin{array}{llllllllllllllll}M-27 & 181 & 1124 & \mathrm{C} & 10 & \mathrm{H}\end{array}$

$\begin{array}{llllll}181 & 1124 & \mathrm{C} & 10 & \mathrm{H} \\ 181 & 1124 & \mathrm{C} & 11 & \mathrm{H}\end{array}$

$1811124 \mathrm{C} 11 \quad \mathrm{H}$

$1811124 \mathrm{C} 11 \quad \mathrm{H}$

$1811124 \mathrm{C} \quad 11 \quad \mathrm{H}$

$\begin{array}{llllll}\text { AT- }-254 & 181 & 1124 & \mathrm{C} & 11 & \mathrm{H}\end{array}$

$\begin{array}{llllll}\text { AT-256 } & 181 & 1124 & \mathrm{C} & 12 & \mathrm{H}\end{array}$

$1811124 \mathrm{C} \quad 12 \quad \mathrm{H}$

1811124 C $12 \quad \mathrm{H}$

$1811124 \mathrm{C} 12 \quad \mathrm{H}$

$\begin{array}{llllllllllllllllll}\text { AT-268 } & 181 & 1124 & \mathrm{C} & 12 & \mathrm{H}\end{array}$

$\begin{array}{lllllllllllllllll}181 & 1124 & \mathrm{C} & 12 & \mathrm{H}\end{array}$

$\begin{array}{lllllll}181 & 1124 & \mathrm{C} & 12 & \mathrm{H}\end{array}$

$181 \quad 1124 \quad \mathrm{C} \quad 12 \quad \mathrm{H}$

$\begin{array}{lllllllll}181 & 1124 & \mathrm{C} & 12 & \mathrm{H}\end{array}$

$\begin{array}{llllll}181 & 1124 & \mathrm{C} & 12 & \mathrm{H}\end{array}$

$\begin{array}{lllllllll}181 & 1124 & \mathrm{C} & 12 & \mathrm{H}\end{array}$

$\begin{array}{llllllllllllllll}181 & 1124 & \mathrm{C} & 12 & \mathrm{H}\end{array}$

1811124 C $13 \quad \mathrm{H}$ $\begin{array}{lllll}181 & 1124 & \mathrm{C} & 13 & \mathrm{H}\end{array}$

$\begin{array}{llllllllllll}\text { AT- } 253 & 181 & 1124 & \mathrm{C} & 13 & \mathrm{H}\end{array}$

$\begin{array}{llllll}181 & 1124 & \mathrm{C} & 13 & \mathrm{H}\end{array}$

$\begin{array}{lllllllllllll}\text { AT-258 } & 181 & 1124 & \mathrm{C} & 13 & \mathrm{H}\end{array}$

$\begin{array}{lllll}181 & 1124 & \mathrm{C} & 14 & \mathrm{H} \\ 181 & 1124 & \mathrm{C} & 14 & \mathrm{H}\end{array}$

$1811124 \mathrm{C} \quad 15 \quad \mathrm{H}$

$\begin{array}{llllllllll}181 & 1124 & \mathrm{C} & 15 & \mathrm{H}\end{array}$

$181 \quad 1124 \quad \mathrm{C} \quad 15 \quad \mathrm{H}$

$\begin{array}{lllllll}181 & 1124 & \mathrm{C} & 15 & \mathrm{H}\end{array}$

$\begin{array}{llllll}\text { AT-269 } 181 & 1124 & \mathrm{C} & 15 & \mathrm{H}\end{array}$

$1811124 \mathrm{C} \quad 15 \quad \mathrm{H}$

$181 \quad 1124 \quad \mathrm{C} \quad 15 \quad \mathrm{H}$

$\begin{array}{lllllll}181 & 1124 & \mathrm{C} & 15 & \mathrm{H}\end{array}$

$\begin{array}{lllll}181 & 1124 & \mathrm{C} & 16 & \mathrm{H} \\ 181 & 1124 & \mathrm{C} & 16 & \mathrm{H}\end{array}$

$1811124 \mathrm{C} \quad 16 \quad \mathrm{H}$

$1811124 \mathrm{C} \quad 16 \quad \mathrm{H}$

$\begin{array}{llllll}181 & 1124 & \mathrm{C} & 16 & \mathrm{H}\end{array}$

$\begin{array}{lllll}181 & 1124 & \mathrm{C} & 17 & \mathrm{X}\end{array}$

$\begin{array}{llllllllll}181 & 1124 & C & 17 & X\end{array}$

AT-266 $181 \quad 1124 \quad \mathrm{C} \quad 17 \quad \mathrm{X}$

$\begin{array}{lllll}181 & 1124 & \mathrm{C} & 17 & \mathrm{X} \\ 181 & 1124 & \mathrm{C} & 18 & \mathrm{X}\end{array}$

$\begin{array}{lllll}181 & 1124 & \mathrm{C} & 18 & \mathrm{X} \\ 181 & 1124 & \mathrm{C} & 18 & \mathrm{X}\end{array}$

$\begin{array}{llllll}181 & 1124 & \text { C } 18 & X\end{array}$

$\begin{array}{llllll}181 & 1124 & C & 18 & X\end{array}$

1811124 C $20 \quad X$

$\begin{array}{llllll}181 & 1124 & C & 20 & X\end{array}$

$181 \quad 1124$ C $21 \quad X$ $\begin{array}{ll}95 & 72.15\end{array}$

$\begin{array}{ll}146 & 74.16 \\ 109 & 75.79\end{array}$

$130 \quad 84.1$

$145 \quad 87.1$

$20 \quad 87.4$

$\begin{array}{ll}78 & 89.48 \\ 40 & 90.6\end{array}$

$\begin{array}{cc}40 & 90.6 \\ 129 & 91.49\end{array}$

$71 \quad 92.41$

$133 \quad 93.03$

$25 \quad 93.45$
99

99
130

$130 \quad 95$

$51 \quad 95.71$

$\begin{array}{cr}9 & 96.79 \\ 142 & 98.12\end{array}$

$\begin{array}{cr}142 & 98.12 \\ 9 & 98.29\end{array}$

29
132 $\quad 98.49$

$132 \quad 99.52$

$\begin{array}{ll}15 & 101.35\end{array}$

$\begin{array}{ll}133 & 106.03\end{array}$

$\begin{array}{cr}47 & 106.67 \\ 9 & 107.79\end{array}$

$\begin{array}{cc}9 & 107.79 \\ 94 & 111.64\end{array}$

$\begin{array}{ll}33 & 112.53\end{array}$

$\begin{array}{ll}39 & 114.59\end{array}$

$\begin{array}{ll}65 & 114.85\end{array}$

$\begin{array}{lll}114 & 115.34 & 5 Y R \\ 123 & 115.43\end{array}$

$\begin{array}{ll}123 & 115.43 \\ 147 & 115.67\end{array}$

$\begin{array}{ll}69 & 116.39\end{array}$

$\begin{array}{ll}72 & 116.42\end{array}$

$144 \quad 118.64$

$\begin{array}{ll}8.5 & 118.785\end{array}$

$\begin{array}{cc}10 & 118.8 \\ 105.5 & 119.755\end{array}$

$\begin{array}{ll}105.5 & 119.755\end{array}$

$124.5 \quad 121.445$

$\begin{array}{ll}77 & 127.47\end{array}$

$\begin{array}{ll}72 & 128.92\end{array}$

$101 \quad 130.71$

$\begin{array}{ll}60 & 131.8\end{array}$

\begin{tabular}{ll}
$137 \quad 133.07$ \\
\hline
\end{tabular}

$122 \quad 143.92$

$41 \quad 144.61$

$123 \quad 145.43$

$\begin{array}{ll}109 & 146.79\end{array}$

$148 \quad 147.18$
41

$41 \quad 147.61$

$71 \quad 147.91$

$38 \quad 149.08$

$20 \quad 152.4$

$\begin{array}{ll}64 & 152.84\end{array}$

$118 \quad 153.38$

$136.5 \quad 155.065$

$\begin{array}{ll}23.5 & 156.935\end{array}$

$\begin{array}{ll}110 & 160.3\end{array}$

$\begin{array}{cc}13.5 & 165.335 \\ 119 & 166.39\end{array}$

$\begin{array}{ll}119 & 166.39 \\ 104 & 167.74\end{array}$

$\begin{array}{ll}104 & 167.74 \\ 130 & 171.6\end{array}$

$140 \quad 176.2$

$119 \quad 177.49$

$150 \quad 177.8$

$2.5 \quad 188.025$

$143 \quad 195.43$

$\begin{array}{ll}75 & 204.45 \\ 45 & 207.15\end{array}$
$137 \quad 74.07$

$\begin{array}{ll}113 & 132.83\end{array}$
$5 \mathrm{Y} 5 /$ $\mathrm{N} 4$

pink $\mathrm{N} 4$ base

$5 Y R 7 / 1$

$5 Y R 7 / 1$

$5 Y 6 / 1$ to $5 / 1$

light pink

5YR 4/1 (base), 6/1 (top)

5YR 4/1 (base), 6/1 (top) $5 \mathrm{YR} 4 / 1$

pink (base), 5YR 4/1 (top) pink

pink (base), 5YR 4/1 (top) 5YR 5/1

$5 \mathrm{YR} 7 / 1$
$5 \mathrm{YR} 4 / 2$
$5 \mathrm{YR} 4 / 1$
$5 \mathrm{YR} 6 / 1$

5YR 7/2 (base), 5YR 6/1 (top)

burrowed (Planolites) $5 Y R 6 / 1$ $5 Y R 5 / 2$ YR 7/1; one ash with 2 layers below?

$$
\begin{aligned}
& 5 \text { YR } 7 / 1 \\
& 5 \text { YR } 5 / 3
\end{aligned}
$$

bioturbated as

5 YR 5/1

5 YR $8 / 1$

5YR 7/1

$5 Y R 7 / 1$

$5 Y R 7 / 1$

$5 Y R 7 / 2$, pinkish grey

5YR 4/1 (base), 5YR 3/1 (top) $5 Y R 7 / 1$, light grey

5YR 5/2 (base), 5YR 6/1 (top)

5YR $5 / 1$ to $7 / 1$

5 YR $6 / 1$

5 YR $7 / 1$

5YR $6 / 1$ (base) to $4 / 1$ to $5 / 1$ (top)

$5 Y R 7 / 1$.

$5 Y R 8 / 1$

SYR 7/2

5YR 5/1

$5 Y$ R $6 / 1$

$5 \mathrm{YR} 7 / 1$, green base

$5 Y R 6 / 1$

5YR 7/1

washed out ash?

5YR 7/1

$5 Y R 7 / 1$

$5 Y R 7 / 1$

5YR 7/1

$5 Y R 7 / 1$

$5 Y R 7 / 1$

altered ash - clayey

altered ash - clayey

altered ash
5YR 6/1
5 YR 4/2 (base), 5YR 6/2 (top)
Number

$\begin{array}{lllll}59 & 71.47 & 5 & 2.1281 & 2.146\end{array}$

$\begin{array}{lllll}60 & 71.94 & 9 & 2.1496 & 2.165\end{array}$

$\begin{array}{lllll}61 & 72.88 & 6 & 2.1990 & 2.205 \\ 62 & 73.14 & 8 & 2.2088 & 2.216\end{array}$

$\begin{array}{lllll}63 & 73.93 & 5 & 2.2478 & 2.250\end{array}$

$\begin{array}{lllll}64 & 74.69 & 6 & 2.2851 & 2.283\end{array}$

$\begin{array}{lllll}65 & 76.61 & 2 & 2.3569 & 2.365 \\ 66 & 76.70 & 3 & 2.3596 & 2.369\end{array}$

$\begin{array}{llcll}67 & 78.19 & 13 & 2.4280 & 2.433 \\ 68 & 86.42 & 2 & 2.8748 & 2.875\end{array}$

$\begin{array}{lllll}68 & 86.42 & 2 & 2.8748 & 2.875 \\ 70 & 89.90 & 2 & 3.0404 & 3.060\end{array}$

$\begin{array}{lllll}71 & 90.20 & 30 & 3.0547 & 3.090\end{array}$

$\begin{array}{lllll}72 & 92.28 & 11 & 3.1537 & 3.269 \\ 73 & 93.40 & 10 & 3.2070 & 3.342\end{array}$

$\begin{array}{lllll}74 & 94.29 & 5 & 3.2493 & 3.396\end{array}$

$\begin{array}{ll}3.2931 & 3.453\end{array}$

$\begin{array}{ll}3.2931 & 3.453 \\ 3.3226 & 3.490\end{array}$

$\begin{array}{ll}3.3426 & 3.516\end{array}$

$\begin{array}{ll}3.4716 & 3.687\end{array}$

$\begin{array}{ll}3.4959 & 3.720\end{array}$

$3.5201 \quad 3.753$

$3.5240 \quad 3.822$

$\begin{array}{ll}3.6349 & 3.908 \\ 3.6429 & 3.919\end{array}$

$\begin{array}{ll}3.6429 & 3.930\end{array}$

$\begin{array}{ll}3.6525 & 3.930 \\ 3.7015 & 3.997\end{array}$

$\begin{array}{ll}3.7015 & 3.997 \\ 3.7886 & 4.117\end{array}$

$4.1027 \quad 4.520$

$4.1332 \quad 4.560$

$4.1865 \quad 4.650$

$4.3697 \quad 4.950$

$4.4121 \quad 5.085$

$4.5577 \quad 5.160$

$4.5701 \quad 5.170$

$4.5934 \quad 5.200$
4.5977

$4.5977 \quad 5.201$

$\begin{array}{ll}4.6091 & 5.217 \\ 4.6434 & 5.250\end{array}$

$4.6448 \quad 5.255$

$\begin{array}{ll}4.6448 & 5.255 \\ 4.7505 & 5.378\end{array}$

$\begin{array}{ll}4.7505 & 5.378 \\ 4.7576 & 5.387\end{array}$

$4.7581 \quad 5.590$

$4.8038 \quad 5.440$

$4.8842 \quad 5.535$
5.0955

$5.0955 \quad 5.942$

$\begin{array}{ll}5.3073 & 6.015\end{array}$

$5.3573 \quad 6.066$

$5.3925 \quad 6.100$

$5.4444 \quad 6.154$

$\begin{array}{ll}5.5686 & 6.264\end{array}$

$\begin{array}{ll}5.5801 & 6.279 \\ 6.1517 & 6.990\end{array}$

6.1845

$\begin{array}{ll}6.1845 & 7.058 \\ 6.2235 & 7.110\end{array}$

$\begin{array}{ll}6.2235 & 7.110 \\ 6.2883 & 7.166\end{array}$

$6.3068 \quad 7.180$

$\begin{array}{ll}6.3273 & 7.210\end{array}$

$6.3416 \quad 7.220$

$6.3973 \quad 7.280$

$\begin{array}{ll}6.5781 & 7.550\end{array}$

$\begin{array}{ll}6.5991 & 7.580\end{array}$

$6.6248-7.590$
6.7052

$\begin{array}{ll}6.7052 & 7.660\end{array}$

$\begin{array}{ll}6.7942 & 7.820 \\ 8.3800 & 8.090\end{array}$

$8.4530 \quad 8.370$

8.5460
8.790

$8.7910 \quad 8.610$

\begin{tabular}{l}
$9.0500 \quad 8.890$ \\
\hline
\end{tabular}

9.180

9.280

10.412

10.990

11.160

Table A1: Samples prefixed "AT-" were previously assigned by Carter et al. (2004) and those with the prefix "M-" were ordered from the Integrated Ocean Drilling Program's Gulf Coast Core Repository (Texas, USA) and assigned by the author. 


\section{Appendix Two}

\section{Major Element Data}

Table A2. Mean major element composition of glass shards from tephra layers analysed in this study as measured by electron probe microanalysis (EPMA). 


\begin{tabular}{|c|c|c|c|c|c|c|c|c|c|c|c|c|}
\hline Sample number ${ }^{a}$ & \multicolumn{2}{|l|}{ M-1 } & \multicolumn{2}{|c|}{ M-2 (1) } & \multicolumn{2}{|c|}{ M-2 (2) } & \multicolumn{2}{|l|}{ M-3 } & \multicolumn{2}{|c|}{ M-4 (1) } & \multicolumn{2}{|c|}{ M-4 (2) } \\
\hline Sample correlative ${ }^{b}$ & \multicolumn{2}{|l|}{ AT-503 } & \multicolumn{2}{|c|}{ AT-313 } & \multicolumn{2}{|c|}{ AT-313 } & \multicolumn{2}{|c|}{ AT-504 } & \multicolumn{2}{|c|}{ AT-326 } & \multicolumn{2}{|c|}{ AT-326 } \\
\hline Sample details ${ }^{c}$ & \multicolumn{2}{|c|}{$1124 \mathrm{C}-7 \mathrm{H}-3$} & \multicolumn{2}{|c|}{$1124 \mathrm{C}-7 \mathrm{H}-3$} & \multicolumn{2}{|c|}{$1124 \mathrm{C}-7 \mathrm{H}-3$} & \multicolumn{2}{|c|}{$1124 \mathrm{C}-7 \mathrm{H}-4$} & \multicolumn{2}{|c|}{$1124 \mathrm{C}-7 \mathrm{H}-4$} & \multicolumn{2}{|c|}{$1124 \mathrm{C}-7 \mathrm{H}-4$} \\
\hline Base $^{d}$ & \multicolumn{2}{|l|}{$73 \mathrm{~cm}$} & \multicolumn{2}{|c|}{$120 \mathrm{~cm}$} & \multicolumn{2}{|l|}{$120 \mathrm{~cm}$} & \multicolumn{2}{|l|}{$64 \mathrm{~cm}$} & \multicolumn{2}{|l|}{$90 \mathrm{~cm}$} & \multicolumn{2}{|l|}{$90 \mathrm{~cm}$} \\
\hline $\operatorname{mbsf}^{e}$ & \multicolumn{2}{|l|}{$68.93 \mathrm{~m}$} & \multicolumn{2}{|c|}{$69.40 \mathrm{~m}$} & \multicolumn{2}{|c|}{$69.40 \mathrm{~m}$} & \multicolumn{2}{|c|}{$70.34 \mathrm{~m}$} & \multicolumn{2}{|c|}{$70.60 \mathrm{~m}$} & \multicolumn{2}{|c|}{$70.60 \mathrm{~m}$} \\
\hline Age (Ma) & \multicolumn{2}{|l|}{2.145} & \multicolumn{2}{|l|}{2.165} & \multicolumn{2}{|l|}{2.165} & \multicolumn{2}{|l|}{2.205} & 2.216 & & 2.216 & \\
\hline$n^{f}$ & 18 & & 11 & & 7 & & 16 & & 12 & & 4 & \\
\hline EPMA & Mean $^{\mathrm{g}}$ & $2 s d^{h}$ & & & & & & & & & & \\
\hline $\mathrm{SiO}_{2}(\text { wt. } \%)^{\mathrm{i}}$ & 76.9 & 1.79 & 78.0 & 0.69 & 78.0 & 0.38 & 77.5 & 0.57 & 74.2 & 1.22 & 77.4 & 0.36 \\
\hline $\mathrm{TiO}_{2}$ & 0.16 & 0.10 & 0.11 & 0.04 & 0.15 & 0.07 & 0.12 & 0.08 & 0.22 & 0.09 & 0.09 & 0.13 \\
\hline $\mathrm{Al}_{2} \mathrm{O}_{3}$ & 12.6 & 0.51 & 12.2 & 0.29 & 12.2 & 0.31 & 12.7 & 0.36 & 13.7 & 0.47 & 12.8 & 0.19 \\
\hline $\mathrm{FeO}^{\mathrm{j}}$ & 1.63 & 0.42 & 1.33 & 0.33 & 1.42 & 0.16 & 1.16 & 0.19 & 2.70 & 0.54 & 1.18 & 0.06 \\
\hline MgO & 0.13 & 0.08 & 0.07 & 0.04 & 0.07 & 0.05 & 0.11 & 0.05 & 0.17 & 0.07 & 0.09 & 0.07 \\
\hline $\mathrm{CaO}$ & 1.08 & 0.19 & 0.82 & 0.12 & 0.90 & 0.14 & 1.01 & 0.30 & 1.64 & 0.30 & 0.95 & 0.25 \\
\hline $\mathrm{Na}_{2} \mathrm{O}$ & 3.72 & 1.15 & 3.69 & 0.35 & 3.76 & 0.27 & 3.41 & 0.34 & 4.03 & 0.17 & 3.53 & 0.37 \\
\hline $\mathrm{K}_{2} \mathrm{O}$ & 3.45 & 0.40 & 3.56 & 0.30 & 3.23 & 0.15 & 3.79 & 0.54 & 3.16 & 0.28 & 3.84 & 0.21 \\
\hline Cl & 0.25 & 0.10 & 0.22 & 0.06 & 0.24 & 0.08 & 0.22 & 0.07 & 0.19 & 0.07 & 0.20 & 0.05 \\
\hline Total $^{k}$ & 95.26 & 2.35 & 95.48 & 1.91 & 95.03 & 0.96 & 95.85 & 1.31 & 95.09 & 2.01 & 94.52 & 1.06 \\
\hline
\end{tabular}

Table A2: Mean major element composition of glass shards from tephra layers analysed in this thesis as measured by electron probe microanalysis (EPMA). 


\begin{tabular}{|c|c|c|c|c|c|c|}
\hline Sample number ${ }^{\mathrm{a}}$ & M-5 & M-6 & M-7 & M-8 & M-9 (1) & M-9 (2) \\
\hline \multicolumn{7}{|c|}{ Sample correlative $^{b}$} \\
\hline Sample details ${ }^{c}$ & $1124 \mathrm{C}-7 \mathrm{H}-5$ & $1124 \mathrm{C}-7 \mathrm{H}-5$ & $1124 \mathrm{C}-7 \mathrm{H}-6$ & $1124 \mathrm{C}-7 \mathrm{H}-6$ & $1124 \mathrm{C}-8 \mathrm{H}-1$ & $1124 \mathrm{C}-8 \mathrm{H}-1$ \\
\hline Base $^{d}$ & $19 \mathrm{~cm}$ & $95 \mathrm{~cm}$ & $137 \mathrm{~cm}$ & $146 \mathrm{~cm}$ & $109 \mathrm{~cm}$ & $109 \mathrm{~cm}$ \\
\hline $\mathrm{mbsf}^{\mathrm{e}}$ & $71.39 \mathrm{~m}$ & $72.15 \mathrm{~m}$ & $74.07 \mathrm{~m}$ & $74.16 \mathrm{~m}$ & $75.79 \mathrm{~m}$ & $75.79 \mathrm{~m}$ \\
\hline Age (Ma) & 2.250 & 2.283 & 2.365 & 2.369 & 2.433 & 2.433 \\
\hline$n^{f}$ & 11 & 15 & 21 & 15 & 8 & 7 \\
\hline
\end{tabular}

\begin{tabular}{|c|c|c|c|c|c|c|c|c|c|c|c|c|}
\hline EPMA & Mean $^{\mathrm{g}}$ & $2 s d^{h}$ & & & & & & & & & & \\
\hline $\mathrm{SiO}_{2}(\text { wt. } \%)^{\mathrm{i}}$ & 76.9 & 1.03 & 76.9 & 0.42 & 76.2 & 0.89 & 76.1 & 0.64 & 77.2 & 0.59 & 76.9 & 0.41 \\
\hline $\mathrm{TiO}_{2}$ & 0.15 & 0.11 & 0.15 & 0.12 & 0.17 & 0.06 & 0.19 & 0.12 & 0.15 & 0.06 & 0.27 & 0.11 \\
\hline $\mathrm{Al}_{2} \mathrm{O}_{3}$ & 13.1 & 0.86 & 13.0 & 0.23 & 13.1 & 0.42 & 13.1 & 0.38 & 12.9 & 0.16 & 12.7 & 0.30 \\
\hline $\mathrm{FeO}^{\mathrm{j}}$ & 1.20 & 0.25 & 1.13 & 0.26 & 1.73 & 0.35 & 1.56 & 0.25 & 1.14 & 0.17 & 1.55 & 0.12 \\
\hline $\mathrm{MgO}$ & 0.15 & 0.10 & 0.12 & 0.08 & 0.12 & 0.05 & 0.18 & 0.09 & 0.14 & 0.05 & 0.28 & 0.07 \\
\hline $\mathrm{CaO}$ & 0.99 & 0.50 & 0.97 & 0.29 & 1.20 & 0.27 & 1.29 & 0.17 & 1.07 & 0.22 & 1.54 & 0.11 \\
\hline $\mathrm{Na}_{2} \mathrm{O}$ & 3.46 & 0.26 & 3.49 & 0.23 & 3.91 & 0.28 & 4.03 & 0.22 & 3.35 & 0.26 & 3.39 & 0.27 \\
\hline $\mathrm{K}_{2} \mathrm{O}$ & 3.80 & 0.79 & 4.02 & 0.46 & 3.37 & 0.23 & 3.33 & 0.16 & 3.82 & 0.65 & 3.14 & 0.19 \\
\hline $\mathrm{Cl}$ & 0.24 & 0.15 & 0.25 & 0.07 & 0.22 & 0.05 & 0.22 & 0.06 & 0.23 & 0.06 & 0.25 & 0.04 \\
\hline Total $^{k}$ & 93.78 & 3.39 & 94.99 & 2.21 & 96.15 & 1.12 & 95.37 & 1.28 & 93.05 & 0.58 & 92.49 & 2.62 \\
\hline
\end{tabular}

Table A2: continued. 


\begin{tabular}{|c|c|c|c|c|c|c|c|c|c|c|c|c|}
\hline Sample number ${ }^{\mathrm{a}}$ & \multicolumn{2}{|l|}{ M-10 } & \multicolumn{2}{|l|}{ M-11 } & \multicolumn{2}{|l|}{ M-12 } & \multicolumn{2}{|l|}{ M-13 } & \multicolumn{2}{|l|}{ M-14 } & \multicolumn{2}{|l|}{ M-15 } \\
\hline \multicolumn{5}{|l|}{ Sample correlative $^{b}$} & \multicolumn{4}{|c|}{ AT-252 } & & & & \\
\hline Sample details ${ }^{\mathrm{c}}$ & \multicolumn{2}{|c|}{$1124 \mathrm{C}-8 \mathrm{H}-7$} & \multicolumn{2}{|c|}{$1124 \mathrm{C}-9 \mathrm{H}-2$} & \multicolumn{2}{|c|}{$1124 \mathrm{C}-9 \mathrm{H}-3$} & \multicolumn{2}{|c|}{$1124 \mathrm{C}-9 \mathrm{H}-4$} & \multicolumn{2}{|c|}{$1124 \mathrm{C}-9 \mathrm{H}-5$} & \multicolumn{2}{|c|}{$1124 \mathrm{C}-9 \mathrm{H}-5$} \\
\hline Base $^{d}$ & \multicolumn{2}{|l|}{$130 \mathrm{~cm}$} & \multicolumn{2}{|l|}{$145 \mathrm{~cm}$} & \multicolumn{2}{|l|}{$20 \mathrm{~cm}$} & \multicolumn{2}{|l|}{$78 \mathrm{~cm}$} & \multicolumn{2}{|l|}{$40 \mathrm{~cm}$} & \multicolumn{2}{|c|}{$129 \mathrm{~cm}$} \\
\hline $\operatorname{mbsf}^{e}$ & \multicolumn{2}{|l|}{$84.10 \mathrm{~m}$} & \multicolumn{2}{|c|}{$87.10 \mathrm{~m}$} & \multicolumn{2}{|c|}{$87.40 \mathrm{~m}$} & \multicolumn{2}{|c|}{$89.48 \mathrm{~m}$} & \multicolumn{2}{|c|}{$90.60 \mathrm{~m}$} & \multicolumn{2}{|c|}{$91.49 \mathrm{~m}$} \\
\hline Age (Ma) & \multicolumn{2}{|l|}{2.875} & \multicolumn{2}{|l|}{3.060} & \multicolumn{2}{|l|}{3.090} & \multicolumn{2}{|l|}{3.269} & \multicolumn{2}{|l|}{3.342} & \multicolumn{2}{|l|}{3.396} \\
\hline$n^{f}$ & 16 & & 18 & & 18 & & 18 & & 12 & & 17 & \\
\hline EPMA & Mean $^{\mathrm{g}}$ & $2 s d^{h}$ & & & & & & & & & & \\
\hline $\mathrm{SiO}_{2}(w \mathrm{t} . \%)^{\mathrm{i}}$ & 77.7 & 0.48 & 77.0 & 1.77 & 76.1 & 1.72 & 77.0 & 1.41 & 69.9 & 1.28 & 76.2 & 0.46 \\
\hline $\mathrm{TiO}_{2}$ & 0.12 & 0.07 & 0.21 & 0.11 & 0.18 & 0.12 & 0.18 & 0.11 & 0.63 & 0.12 & 0.16 & 0.13 \\
\hline $\mathrm{Al}_{2} \mathrm{O}_{3}$ & 12.4 & 0.46 & 12.7 & 0.88 & 13.3 & 1.03 & 13.7 & 0.33 & 14.7 & 0.34 & 13.1 & 0.24 \\
\hline $\mathrm{FeO}^{\mathrm{j}}$ & 1.13 & 0.20 & 1.38 & 0.32 & 1.43 & 0.50 & 1.79 & 0.20 & 3.68 & 0.40 & 1.99 & 0.22 \\
\hline MgO & 0.07 & 0.07 & 0.21 & 0.12 & 0.23 & 0.14 & 0.14 & 0.05 & 0.82 & 0.16 & 0.11 & 0.05 \\
\hline $\mathrm{CaO}$ & 0.80 & 0.16 & 1.40 & 0.38 & 1.37 & 0.48 & 1.22 & 0.17 & 2.95 & 0.83 & 1.18 & 0.10 \\
\hline $\mathrm{Na}_{2} \mathrm{O}$ & 3.80 & 0.26 & 3.50 & 0.47 & 3.84 & 0.32 & 2.62 & 1.31 & 4.46 & 0.28 & 3.78 & 0.32 \\
\hline $\mathrm{K}_{2} \mathrm{O}$ & 3.80 & 0.29 & 3.44 & 0.45 & 3.38 & 0.69 & 3.17 & 0.25 & 2.50 & 0.23 & 3.28 & 0.30 \\
\hline $\mathrm{Cl}$ & 0.17 & 0.08 & 0.18 & 0.09 & 0.19 & 0.07 & 0.18 & 0.06 & 0.32 & 0.08 & 0.23 & 0.06 \\
\hline Total $^{k}$ & 94.84 & 2.12 & 95.29 & 2.51 & 94.55 & 1.36 & 92.55 & 1.83 & 95.73 & 2.25 & 95.10 & 2.03 \\
\hline
\end{tabular}

Table A2: continued. 


\begin{tabular}{|c|c|c|c|c|c|c|}
\hline Sample number ${ }^{\mathrm{a}}$ & M-16 & M-17 & M-18 & M-19 & M-20 & M-21 \\
\hline Sample correlative & AT-262 & & & & & \\
\hline Sample details ${ }^{c}$ & $1124 \mathrm{C}-9 \mathrm{H}-6$ & $1124 \mathrm{C}-9 \mathrm{H}-6$ & $1124 \mathrm{C}-9 \mathrm{H}-7$ & $1124 \mathrm{C}-10 \mathrm{H}-1$ & $1124 \mathrm{C}-10 \mathrm{H}-1$ & $1124 \mathrm{C}-10 \mathrm{H}-2$ \\
\hline Base $^{d}$ & $71 \mathrm{~cm}$ & $133 \mathrm{~cm}$ & $25 \mathrm{~cm}$ & $99 \mathrm{~cm}$ & $130 \mathrm{~cm}$ & $51 \mathrm{~cm}$ \\
\hline mbsf $^{e}$ & $92.41 \mathrm{~m}$ & $93.03 \mathrm{~m}$ & $93.45 \mathrm{~m}$ & $94.69 \mathrm{~m}$ & $95.00 \mathrm{~m}$ & $95,71 \mathrm{~m}$ \\
\hline Age (Ma) & 3.453 & 3.490 & 3.516 & 3.687 & 3.720 & 3.753 \\
\hline$n^{f}$ & 17 & 15 & 16 & 17 & 21 & 17 \\
\hline
\end{tabular}

\begin{tabular}{|c|c|c|c|c|c|c|c|c|c|c|c|c|}
\hline ЕРМА & Mean $^{\mathrm{g}}$ & $2 s d^{h}$ & & & & & & & & & & \\
\hline $\mathrm{SiO}_{2}(\text { wt. } \%)^{\mathrm{i}}$ & 76.6 & 0.67 & 76.0 & 0.74 & 76.8 & 1.30 & 75.3 & 1.12 & 77.1 & 0.34 & 75.5 & 0.48 \\
\hline $\mathrm{TiO}_{2}$ & 0.13 & 0.08 & 0.21 & 0.05 & 0.16 & 0.11 & 0.18 & 0.06 & 0.11 & 0.08 & 0.21 & 0.08 \\
\hline $\mathrm{Al}_{2} \mathrm{O}_{3}$ & 12.7 & 0.40 & 13.2 & 0.27 & 12.8 & 0.89 & 13.5 & 0.80 & 12.9 & 0.20 & 13.5 & 0.28 \\
\hline $\mathrm{FeO}^{\mathrm{j}}$ & 1.70 & 0.20 & 1.59 & 0.25 & 1.65 & 0.18 & 2.08 & 0.29 & 1.17 & 0.15 & 1.93 & 0.25 \\
\hline MgO & 0.09 & 0.05 & 0.19 & 0.06 & 0.08 & 0.05 & 0.13 & 0.05 & 0.10 & 0.04 & 0.17 & 0.06 \\
\hline $\mathrm{CaO}$ & 1.06 & 0.22 & 1.33 & 0.32 & 1.05 & 0.12 & 1.30 & 0.14 & 0.92 & 0.16 & 1.38 & 0.15 \\
\hline $\mathrm{Na}_{2} \mathrm{O}$ & 4.07 & 0.69 & 4.03 & 0.28 & 3.76 & 0.43 & 3.89 & 0.34 & 3.70 & 0.35 & 4.26 & 0.28 \\
\hline $\mathrm{K}_{2} \mathrm{O}$ & 3.43 & 0.63 & 3.23 & 0.29 & 3.48 & 0.18 & 3.46 & 0.28 & 3.80 & 0.49 & 2.89 & 0.27 \\
\hline $\mathrm{Cl}$ & 0.21 & 0.09 & 0.20 & 0.09 & 0.22 & 0.08 & 0.16 & 0.06 & 0.16 & 0.06 & 0.19 & 0.07 \\
\hline Total $^{\mathrm{k}}$ & 96.15 & 3.21 & 93.86 & 1.60 & 94.22 & 3.52 & 93.99 & 4.33 & 94.91 & 1.35 & 93.08 & 1.74 \\
\hline
\end{tabular}

Table A2: continued. 


\begin{tabular}{|c|c|c|c|c|c|c|c|c|c|c|c|c|}
\hline Sample number ${ }^{a}$ & \multicolumn{2}{|l|}{ M-22 } & \multicolumn{2}{|l|}{ M-23 } & \multicolumn{2}{|l|}{ M-24 } & \multicolumn{2}{|l|}{ M-25 } & \multicolumn{2}{|l|}{ M-26 } & \multicolumn{2}{|l|}{ M-27 } \\
\hline \multicolumn{13}{|c|}{ Sample correlative $^{b}$} \\
\hline Sample details ${ }^{c}$ & \multicolumn{2}{|c|}{$1124 \mathrm{C}-10 \mathrm{H}-3$} & \multicolumn{2}{|c|}{$1124 \mathrm{C}-10 \mathrm{H}-3$} & \multicolumn{2}{|c|}{$1124 \mathrm{C}-10 \mathrm{H}-4$} & \multicolumn{2}{|c|}{$1124 \mathrm{C}-10 \mathrm{H}-4$} & \multicolumn{2}{|c|}{$1124 \mathrm{C}-10 \mathrm{H}-4$} & \multicolumn{2}{|c|}{$1124 \mathrm{C}-10 \mathrm{H}-6$} \\
\hline Base $^{d}$ & \multicolumn{2}{|l|}{$9 \mathrm{~cm}$} & \multicolumn{2}{|l|}{$142 \mathrm{~cm}$} & \multicolumn{2}{|l|}{$9 \mathrm{~cm}$} & \multicolumn{2}{|l|}{$29 \mathrm{~cm}$} & \multicolumn{2}{|c|}{$132 \mathrm{~cm}$} & \multicolumn{2}{|c|}{$15 \mathrm{~cm}$} \\
\hline mbsf $^{e}$ & \multicolumn{2}{|l|}{$96.79 \mathrm{~m}$} & \multicolumn{2}{|c|}{$98.12 \mathrm{~m}$} & \multicolumn{2}{|c|}{$98.29 \mathrm{~m}$} & \multicolumn{2}{|l|}{98.49} & \multicolumn{2}{|c|}{$99.52 \mathrm{~m}$} & \multicolumn{2}{|c|}{$101.35 \mathrm{~m}$} \\
\hline Age (Ma) & \multicolumn{2}{|l|}{3.822} & \multicolumn{2}{|l|}{3.908} & \multicolumn{2}{|l|}{3.919} & \multicolumn{2}{|l|}{3.930} & \multicolumn{2}{|l|}{3.997} & \multicolumn{2}{|l|}{4.117} \\
\hline$n^{f}$ & 17 & & 16 & & 17 & & 17 & & 15 & & 18 & \\
\hline ЕРMА & Mean $^{\mathrm{g}}$ & $2 s d^{h}$ & & & & & & & & & & \\
\hline $\mathrm{SiO}_{2}(\text { wt. } \%)^{\mathrm{i}}$ & 77.3 & 0.42 & 73.3 & 0.55 & 73.1 & 2.99 & 77.7 & 0.60 & 73.9 & 1.92 & 77.6 & 0.36 \\
\hline $\mathrm{TiO}_{2}$ & 0.14 & 0.06 & 0.27 & 0.08 & 0.41 & 0.19 & 0.16 & 0.08 & 0.42 & 0.17 & 0.08 & 0.06 \\
\hline $\mathrm{Al}_{2} \mathrm{O}_{3}$ & 12.5 & 0.32 & 14.5 & 0.25 & 13.8 & 1.06 & 12.3 & 0.23 & 13.8 & 0.69 & 12.7 & 0.23 \\
\hline $\mathrm{FeO}^{\mathrm{j}}$ & 1.49 & 0.24 & 2.68 & 0.35 & 2.94 & 1.15 & 1.42 & 0.32 & 2.26 & 0.49 & 1.23 & 0.21 \\
\hline MgO & 0.13 & 0.04 & 0.25 & 0.05 & 0.37 & 0.20 & 0.10 & 0.04 & 0.41 & 0.22 & 0.04 & 0.04 \\
\hline $\mathrm{CaO}$ & 1.24 & 0.16 & 1.81 & 0.11 & 1.82 & 0.52 & 1.10 & 0.15 & 1.48 & 0.53 & 0.87 & 0.10 \\
\hline $\mathrm{Na}_{2} \mathrm{O}$ & 3.81 & 0.21 & 4.32 & 0.24 & 4.68 & 0.75 & 3.63 & 0.84 & 5.00 & 0.37 & 3.92 & 0.24 \\
\hline $\mathrm{K}_{2} \mathrm{O}$ & 3.21 & 0.42 & 2.63 & 0.19 & 2.49 & 0.61 & 3.37 & 0.49 & 2.23 & 0.28 & 3.42 & 0.28 \\
\hline $\mathrm{Cl}$ & 0.15 & 0.05 & 0.24 & 0.07 & 0.39 & 0.18 & 0.21 & 0.07 & 0.43 & 0.07 & 0.16 & 0.07 \\
\hline Total $^{k}$ & 95.30 & 2.39 & 92.73 & 1.25 & 94.91 & 2.72 & 94.55 & 2.05 & 98.01 & 1.59 & 94.72 & 1.24 \\
\hline
\end{tabular}




\begin{tabular}{|c|c|c|c|c|c|c|}
\hline Sample number ${ }^{a}$ & M-28 (1) & M-28 (2) & M-29 & M-30 & M-31 & M-32 \\
\hline \multicolumn{6}{|l|}{ Sample correlative $^{b}$} & AT-254 \\
\hline Sample details ${ }^{c}$ & $1124 \mathrm{C}-11 \mathrm{H}-2$ & $1124 \mathrm{C}-11 \mathrm{H}-2$ & $1124 \mathrm{C}-11 \mathrm{H}-3$ & $1124 \mathrm{C}-11 \mathrm{H}-4$ & $1124 \mathrm{C}-11 \mathrm{H}-6$ & $1124 \mathrm{C}-11 \mathrm{H}-7$ \\
\hline Base $^{d}$ & $133 \mathrm{~cm}$ & $133 \mathrm{~cm}$ & $47 \mathrm{~cm}$ & $9 \mathrm{~cm}$ & $94 \mathrm{~cm}$ & $33 \mathrm{~cm}$ \\
\hline $\operatorname{mbsf}^{e}$ & $106.03 \mathrm{~m}$ & $106.03 \mathrm{~m}$ & $106.67 \mathrm{~m}$ & $107.79 \mathrm{~m}$ & $111.64 \mathrm{~m}$ & $112.53 \mathrm{~m}$ \\
\hline Age (Ma) & 4.520 & 4.520 & 4.560 & 4.650 & 4.950 & 5.085 \\
\hline$n^{f}$ & 12 & 4 & 17 & 16 & 17 & 17 \\
\hline
\end{tabular}

\begin{tabular}{|c|c|c|c|c|c|c|c|c|c|c|c|c|}
\hline ЕРМА & Mean $^{\mathrm{g}}$ & $2 s d^{h}$ & & & & & & & & & & \\
\hline $\mathrm{SiO}_{2}(\text { wt. } \%)^{\mathrm{i}}$ & 77.6 & 0.69 & 74.3 & 0.22 & 78.0 & 0.45 & 77.9 & 0.89 & 72.0 & 1.32 & 74.1 & 0.67 \\
\hline $\mathrm{TiO}_{2}$ & 0.19 & 0.11 & 0.34 & 0.07 & 0.22 & 0.08 & 0.21 & 0.08 & 0.61 & 0.19 & 0.26 & 0.06 \\
\hline $\mathrm{Al}_{2} \mathrm{O}_{3}$ & 12.2 & 0.38 & 13.6 & 0.23 & 12.1 & 0.22 & 12.3 & 0.52 & 14.9 & 0.72 & 13.5 & 0.46 \\
\hline $\mathrm{FeO}^{\mathrm{j}}$ & 1.32 & 0.24 & 2.15 & 0.31 & 1.20 & 0.18 & 1.16 & 0.17 & 2.54 & 0.28 & 2.97 & 0.38 \\
\hline $\mathrm{MgO}$ & 0.14 & 0.04 & 0.34 & 0.06 & 0.16 & 0.06 & 0.16 & 0.06 & 0.66 & 0.21 & 0.19 & 0.04 \\
\hline $\mathrm{CaO}$ & 0.79 & 0.13 & 1.59 & 0.06 & 0.83 & 0.10 & 0.90 & 0.09 & 2.14 & 0.34 & 1.52 & 0.15 \\
\hline $\mathrm{Na}_{2} \mathrm{O}$ & 3.89 & 0.22 & 4.31 & 0.11 & 3.83 & 0.29 & 3.58 & 0.30 & 4.66 & 0.31 & 4.26 & 0.30 \\
\hline $\mathrm{K}_{2} \mathrm{O}$ & 3.50 & 0.34 & 3.04 & 0.25 & 3.29 & 0.23 & 3.47 & 0.38 & 2.29 & 0.38 & 2.87 & 0.24 \\
\hline $\mathrm{Cl}$ & 0.36 & 0.10 & 0.34 & 0.04 & 0.34 & 0.08 & 0.34 & 0.08 & 0.22 & 0.08 & 0.33 & 0.08 \\
\hline Total $^{k}$ & 96.10 & 1.79 & 96.12 & 1.42 & 97.00 & 1.20 & 95.52 & 3.42 & 93.62 & 1.35 & 94.97 & 2.10 \\
\hline
\end{tabular}

Table A2: continued. 


\begin{tabular}{|c|c|c|c|c|c|c|}
\hline Sample number ${ }^{\mathrm{a}}$ & M-33 (1) & M-33 (2) & M-34 & M-35 & M-36 & M-37 \\
\hline Sample correlative $^{b}$ & AT-256 & AT-256 & & & & AT-268 \\
\hline Sample details ${ }^{c}$ & $1124 \mathrm{C}-12 \mathrm{H}-2$ & $1124 \mathrm{C}-12 \mathrm{H}-2$ & $1124 \mathrm{C}-12 \mathrm{H}-2$ & $1124 \mathrm{C}-12 \mathrm{H}-2$ & $1124 \mathrm{C}-12 \mathrm{H}-2$ & $1124 \mathrm{C}-12 \mathrm{H}-2$ \\
\hline Base $^{d}$ & $39 \mathrm{~cm}$ & $39 \mathrm{~cm}$ & $65 \mathrm{~cm}$ & $114 \mathrm{~cm}$ & $123 \mathrm{~cm}$ & $147 \mathrm{~cm}$ \\
\hline $\operatorname{mbsf}^{e}$ & $114.59 \mathrm{~m}$ & $114.59 \mathrm{~m}$ & $114.85 \mathrm{~m}$ & $115.34 \mathrm{~m}$ & 115.43 & $115.67 \mathrm{~m}$ \\
\hline Age (Ma) & 5.160 & 5.160 & 5.170 & 5.200 & 5.201 & 5.217 \\
\hline$n^{f}$ & 10 & 8 & 18 & 15 & 18 & 14 \\
\hline
\end{tabular}

\begin{tabular}{|c|c|c|c|c|c|c|c|c|c|c|c|c|}
\hline ЕРМА & Mean $^{\mathrm{g}}$ & $2 s d^{h}$ & & & & & & & & & & \\
\hline $\mathrm{SiO}_{2}(\text { wt. } \%)^{\mathrm{i}}$ & 73.3 & 1.00 & 74.7 & 0.31 & 74.5 & 1.41 & 76.8 & 0.44 & 77.7 & 0.61 & 73.4 & 0.76 \\
\hline $\mathrm{TiO}_{2}$ & 0.55 & 0.18 & 0.46 & 0.12 & 0.49 & 0.13 & 0.16 & 0.10 & 0.14 & 0.09 & 0.53 & 0.08 \\
\hline $\mathrm{Al}_{2} \mathrm{O}_{3}$ & 14.2 & 0.76 & 13.6 & 0.39 & 13.7 & 0.85 & 13.0 & 0.54 & 12.5 & 0.33 & 13.6 & 0.45 \\
\hline $\mathrm{FeO}^{\mathrm{j}}$ & 2.30 & 0.40 & 2.01 & 0.14 & 2.11 & 0.29 & 1.32 & 0.22 & 1.25 & 0.19 & 2.72 & 0.34 \\
\hline MgO & 0.49 & 0.12 & 0.40 & 0.04 & 0.41 & 0.05 & 0.14 & 0.04 & 0.13 & 0.05 & 0.49 & 0.08 \\
\hline $\mathrm{CaO}$ & 1.82 & 0.32 & 1.40 & 0.12 & 1.58 & 0.28 & 1.08 & 0.15 & 1.10 & 0.14 & 1.81 & 0.23 \\
\hline $\mathrm{Na}_{2} \mathrm{O}$ & 4.97 & 0.27 & 4.84 & 0.41 & 4.61 & 0.33 & 3.48 & 0.42 & 3.31 & 0.35 & 4.17 & 0.26 \\
\hline $\mathrm{K}_{2} \mathrm{O}$ & 2.16 & 0.30 & 2.32 & 0.28 & 2.31 & 0.30 & 3.79 & 0.21 & 3.69 & 0.28 & 3.00 & 0.20 \\
\hline $\mathrm{Cl}$ & 0.24 & 0.08 & 0.27 & 0.07 & 0.29 & 0.10 & 0.23 & 0.13 & 0.18 & 0.05 & 0.28 & 0.07 \\
\hline Total $^{k}$ & 93.10 & 1.64 & 92.89 & 1.71 & 93.19 & 2.39 & 93.38 & 1.67 & 93.94 & 2.05 & 96.09 & 1.12 \\
\hline
\end{tabular}

Table A2: continued. 


\begin{tabular}{|c|c|c|c|c|c|c|c|c|c|c|c|c|}
\hline Sample number ${ }^{\mathrm{a}}$ & \multicolumn{2}{|l|}{ M-38 } & \multicolumn{2}{|l|}{ M-39 } & \multicolumn{2}{|l|}{ M-40 } & \multicolumn{2}{|l|}{ M-41 } & \multicolumn{2}{|l|}{ M-42 } & \multicolumn{2}{|l|}{ M-43 } \\
\hline \multicolumn{13}{|c|}{ Sample correlative $^{b}$} \\
\hline Sample details ${ }^{c}$ & \multicolumn{2}{|c|}{$1124 \mathrm{C}-12 \mathrm{H}-3$} & \multicolumn{2}{|c|}{$1124 \mathrm{C}-12 \mathrm{H}-3$} & \multicolumn{2}{|c|}{$1124 \mathrm{C}-12 \mathrm{H}-4$} & \multicolumn{2}{|c|}{$1124 \mathrm{C}-12 \mathrm{H}-5$} & \multicolumn{2}{|c|}{$1124 \mathrm{C}-12 \mathrm{H}-5$} & \multicolumn{2}{|c|}{$1124 \mathrm{C}-12 \mathrm{H}-5$} \\
\hline Base $^{d}$ & \multicolumn{2}{|c|}{$69 \mathrm{~cm}$} & \multicolumn{2}{|c|}{$72 \mathrm{~cm}$} & \multicolumn{2}{|c|}{$144 \mathrm{~cm}$} & \multicolumn{2}{|c|}{$8.5 \mathrm{~cm}$} & \multicolumn{2}{|l|}{$10 \mathrm{~cm}$} & \multicolumn{2}{|c|}{$105.5 \mathrm{~cm}$} \\
\hline mbsf $^{e}$ & \multicolumn{2}{|c|}{$116.39 \mathrm{~m}$} & \multicolumn{2}{|l|}{116.42} & \multicolumn{2}{|c|}{$118.54 \mathrm{~m}$} & \multicolumn{2}{|c|}{$118.79 \mathrm{~m}$} & \multicolumn{2}{|c|}{$118.80 \mathrm{~m}$} & \multicolumn{2}{|c|}{$119.76 \mathrm{~m}$} \\
\hline Age (Ma) & \multicolumn{2}{|l|}{5.250} & \multicolumn{2}{|l|}{5.255} & \multicolumn{2}{|l|}{5.378} & \multicolumn{2}{|l|}{5.387} & \multicolumn{2}{|c|}{5.590} & \multicolumn{2}{|c|}{5.440} \\
\hline$n^{f}$ & 3 & & 2 & & 18 & & 18 & & 15 & & 16 & \\
\hline EPMA & Mean $^{\mathrm{g}}$ & $2 s d^{h}$ & & & & & & & & & & \\
\hline $\mathrm{SiO}_{2}(\text { wt. } \%)^{\mathrm{i}}$ & 77.3 & 0.37 & 74.5 & 0.66 & 76.7 & 0.53 & 74.8 & 1.61 & 75.1 & 2.26 & 78.1 & 1.27 \\
\hline $\mathrm{TiO}_{2}$ & 0.19 & 0.04 & 0.39 & 0.02 & 0.23 & 0.11 & 0.38 & 0.09 & 0.36 & 0.18 & 0.19 & 0.07 \\
\hline $\mathrm{Al}_{2} \mathrm{O}_{3}$ & 12.8 & 0.12 & 14.0 & 0.46 & 13.2 & 0.27 & 14.0 & 0.92 & 13.8 & 1.09 & 12.5 & 0.78 \\
\hline $\mathrm{FeO}^{\mathrm{j}}$ & 1.72 & 0.15 & 1.89 & 0.16 & 1.33 & 0.24 & 1.73 & 0.34 & 1.64 & 0.39 & 1.01 & 0.20 \\
\hline MgO & 0.21 & 0.03 & 0.43 & 0.13 & 0.22 & 0.07 & 0.42 & 0.14 & 0.39 & 0.25 & 0.15 & 0.05 \\
\hline $\mathrm{CaO}$ & 1.24 & 0.08 & 1.59 & 0.04 & 1.20 & 0.23 & 1.71 & 0.46 & 1.70 & 0.64 & 0.83 & 0.15 \\
\hline $\mathrm{Na}_{2} \mathrm{O}$ & 4.08 & 0.27 & 5.02 & 0.19 & 3.75 & 0.20 & 4.19 & 0.33 & 4.20 & 0.41 & 4.02 & 0.31 \\
\hline $\mathrm{K}_{2} \mathrm{O}$ & 2.29 & 0.11 & 1.96 & 0.20 & 3.28 & 0.18 & 2.49 & 0.27 & 2.58 & 0.53 & 3.03 & 0.30 \\
\hline $\mathrm{Cl}$ & 0.13 & 0.03 & 0.29 & 0.10 & 0.15 & 0.07 & 0.20 & 0.06 & 0.19 & 0.06 & 0.20 & 0.05 \\
\hline Total $^{k}$ & 94.82 & 1.11 & 95.32 & 1.13 & 92.18 & 1.81 & 93.96 & 3.50 & 92.81 & 1.10 & 94.46 & 3.18 \\
\hline
\end{tabular}

Table A2: continued. 


\begin{tabular}{|c|c|c|c|c|c|c|}
\hline Sample number ${ }^{\mathrm{a}}$ & M-44 & M-45 & M-46 (1) & M-46 (2) & M-46 (3) & M-47 (1) \\
\hline Sample correlative & & & & & & AT-253 \\
\hline Sample details ${ }^{c}$ & $1124 \mathrm{C}-12 \mathrm{H}-6$ & $1124 \mathrm{C}-13 \mathrm{H}-4$ & $1124 \mathrm{C}-13 \mathrm{H}-5$ & $1124 \mathrm{C}-13 \mathrm{H}-5$ & $1124 \mathrm{C}-13 \mathrm{H}-5$ & $1124 \mathrm{C}-13 \mathrm{H}-6$ \\
\hline Base $^{d}$ & $124.5 \mathrm{~cm}$ & $77 \mathrm{~cm}$ & $72 \mathrm{~cm}$ & $72 \mathrm{~cm}$ & $72 \mathrm{~cm}$ & $27 \mathrm{~cm}$ \\
\hline $\operatorname{mbsf}^{e}$ & $121.45 \mathrm{~m}$ & $127.47 \mathrm{~m}$ & $128.92 \mathrm{~m}$ & $128.92 \mathrm{~m}$ & $128.92 \mathrm{~m}$ & $129.97 \mathrm{~m}$ \\
\hline Age (Ma) & 5.535 & 5.942 & 6.015 & 6.015 & 6.015 & 6.066 \\
\hline$n^{f}$ & 17 & 16 & 6 & 4 & 6 & 11 \\
\hline
\end{tabular}

\begin{tabular}{|c|c|c|c|c|c|c|c|c|c|c|c|c|}
\hline ЕРMA & Mean $^{\mathrm{g}}$ & $2 s d^{h}$ & & & & & & & & & & \\
\hline $\mathrm{SiO}_{2}(\text { wt. } \%)^{\mathrm{i}}$ & 75.3 & 0.53 & 74.6 & 0.98 & 67.8 & 2.03 & 75.7 & 0.78 & 59.1 & 5.23 & 75.7 & 1.27 \\
\hline $\mathrm{TiO}_{2}$ & 0.26 & 0.11 & 0.40 & 0.11 & 1.14 & 0.37 & 0.41 & 0.18 & 1.66 & 0.22 & 0.29 & 0.11 \\
\hline $\mathrm{Al}_{2} \mathrm{O}_{3}$ & 13.8 & 0.46 & 13.9 & 0.77 & 14.6 & 0.65 & 13.3 & 0.33 & 15.6 & 1.74 & 13.8 & 0.74 \\
\hline $\mathrm{FeO}^{\mathrm{j}}$ & 2.06 & 0.33 & 1.93 & 0.30 & 5.03 & 0.93 & 2.00 & 0.67 & 8.47 & 1.49 & 1.54 & 0.24 \\
\hline MgO & 0.24 & 0.05 & 0.44 & 0.11 & 1.35 & 0.34 & 0.27 & 0.12 & 2.95 & 0.86 & 0.33 & 0.03 \\
\hline $\mathrm{CaO}$ & 1.36 & 0.13 & 1.81 & 0.25 & 3.65 & 0.95 & 1.30 & 0.54 & 7.15 & 2.83 & 1.55 & 0.26 \\
\hline $\mathrm{Na}_{2} \mathrm{O}$ & 4.16 & 0.78 & 4.15 & 0.41 & 4.65 & 0.38 & 3.96 & 0.83 & 4.01 & 0.21 & 3.91 & 0.32 \\
\hline $\mathrm{K}_{2} \mathrm{O}$ & 2.64 & 1.15 & 2.66 & 0.43 & 1.62 & 0.29 & 2.92 & 1.41 & 0.99 & 0.66 & 2.70 & 0.22 \\
\hline $\mathrm{Cl}$ & 0.14 & 0.06 & 0.14 & 0.05 & 0.15 & 0.06 & 0.15 & 0.09 & 0.12 & 0.07 & 0.21 & 0.07 \\
\hline Total $^{k}$ & 93.37 & 2.18 & 95.48 & 1.47 & 96.71 & 4.91 & 93.91 & 3.17 & 98.40 & 4.03 & 93.23 & 2.55 \\
\hline
\end{tabular}

Table A2: continued. 


\begin{tabular}{|c|c|c|c|c|c|c|}
\hline Sample number ${ }^{\mathrm{a}}$ & M-47 (2) & M-48 & M-49 & M-50 & M-51 & M-52 \\
\hline Sample correlative ${ }^{b}$ & AT-253 & & AT-258 & & & \\
\hline Sample details ${ }^{c}$ & $1124 \mathrm{C}-13 \mathrm{H}-6$ & $1124 \mathrm{C}-13 \mathrm{H}-6$ & $1124 \mathrm{C}-13 \mathrm{H}-7$ & $1124 \mathrm{C}-14 \mathrm{H}-1$ & $1124 \mathrm{C}-14 \mathrm{H}-1$ & $1124 \mathrm{C}-15 \mathrm{H}-2$ \\
\hline Base $^{d}$ & $27 \mathrm{~cm}$ & $101 \mathrm{~cm}$ & $60 \mathrm{~cm}$ & $113 \mathrm{~cm}$ & $137 \mathrm{~cm}$ & $122 \mathrm{~cm}$ \\
\hline $\operatorname{mbsf}^{e}$ & $129.97 \mathrm{~m}$ & $130.71 \mathrm{~m}$ & $131.80 \mathrm{~m}$ & $132.83 \mathrm{~m}$ & $133.07 \mathrm{~m}$ & $143.92 \mathrm{~m}$ \\
\hline Age (Ma) & 6.066 & 6.100 & 6.154 & 6.264 & 6.279 & 6.990 \\
\hline$n^{f}$ & 4 & 18 & 18 & 17 & 18 & 13 \\
\hline
\end{tabular}

\begin{tabular}{|c|c|c|c|c|c|c|c|c|c|c|c|c|}
\hline ЕРMA & Mean $^{\mathrm{g}}$ & $2 s d^{h}$ & & & & & & & & & & \\
\hline $\mathrm{SiO}_{2}(\text { wt. } \%)^{\mathrm{i}}$ & 77.8 & 0.80 & 78.5 & 0.48 & 77.6 & 0.98 & 77.0 & 0.64 & 76.1 & 1.63 & 77.1 & 0.64 \\
\hline $\mathrm{TiO}_{2}$ & 0.27 & 0.06 & 0.26 & 0.07 & 0.16 & 0.09 & 0.17 & 0.10 & 0.23 & 0.11 & 0.11 & 0.09 \\
\hline $\mathrm{Al}_{2} \mathrm{O}_{3}$ & 12.3 & 0.45 & 11.8 & 0.29 & 12.9 & 0.69 & 12.7 & 0.36 & 13.7 & 0.48 & 12.9 & 0.48 \\
\hline $\mathrm{FeO}^{\mathrm{j}}$ & 1.14 & 0.22 & 1.19 & 0.18 & 0.73 & 0.12 & 1.15 & 0.13 & 2.00 & 0.32 & 0.78 & 0.20 \\
\hline MgO & 0.23 & 0.08 & 0.21 & 0.05 & 0.13 & 0.04 & 0.13 & 0.05 & 0.18 & 0.06 & 0.09 & 0.05 \\
\hline $\mathrm{CaO}$ & 1.10 & 0.09 & 1.09 & 0.14 & 0.72 & 0.12 & 0.92 & 0.15 & 1.15 & 0.20 & 0.73 & 0.15 \\
\hline $\mathrm{Na}_{2} \mathrm{O}$ & 3.52 & 0.39 & 3.63 & 0.12 & 3.56 & 0.52 & 3.26 & 0.34 & 3.34 & 1.77 & 3.43 & 0.35 \\
\hline $\mathrm{K}_{2} \mathrm{O}$ & 3.35 & 0.15 & 3.04 & 0.34 & 4.01 & 0.68 & 4.44 & 0.27 & 3.04 & 0.33 & 4.68 & 0.46 \\
\hline $\mathrm{Cl}$ & 0.27 & 0.09 & 0.30 & 0.07 & 0.21 & 0.06 & 0.29 & 0.08 & 0.19 & 0.05 & 0.16 & 0.04 \\
\hline Total $^{k}$ & 93.15 & 2.51 & 95.44 & 1.48 & 94.26 & 2.88 & 93.75 & 1.82 & 93.73 & 2.95 & 95.32 & 1.60 \\
\hline
\end{tabular}

Table A2: continued. 


\begin{tabular}{llllll}
\hline $\begin{array}{l}\text { Sample number } \\
\text { Sample correlative }\end{array}$ & M-53 & M-54 & M-55 & M-56 & M-57 \\
Sample details & & & & MT-269 & \\
Base $^{\text {d }}$ & $1124 \mathrm{C}-15 \mathrm{H}-3$ & $1124 \mathrm{C}-15 \mathrm{H}-3$ & $1124 \mathrm{C}-15 \mathrm{H}-4$ & $1124 \mathrm{C}-15 \mathrm{H}-4$ & $1124 \mathrm{C}-15 \mathrm{H}-5$ \\
mbsf $^{\mathrm{e}}$ & $41 \mathrm{~cm}$ & $123 \mathrm{~cm}$ & $109 \mathrm{~cm}$ & $148 \mathrm{~cm}$ & $41 \mathrm{~cm}$ \\
Age $^{\text {(Ma) }}$ & $144.61 \mathrm{~m}$ & $145.43 \mathrm{~m}$ & $146.79 \mathrm{~m}$ & $147.18 \mathrm{~m}$ & $147.61 \mathrm{~m}$ \\
$\mathbf{n}^{\mathrm{f}}$ & 7.058 & 7.110 & 7.166 & 7.180 & 7.210 \\
\hline \hline
\end{tabular}

\begin{tabular}{|c|c|c|c|c|c|c|c|c|c|c|c|c|}
\hline ЕРMA & Mean $^{\mathrm{g}}$ & $2 s d^{h}$ & & & & & & & & & & \\
\hline $\mathrm{SiO}_{2}(w \mathrm{t} . \%)^{\mathrm{i}}$ & 72.9 & 4.64 & 76.0 & 1.29 & 73.2 & 1.26 & 74.6 & 0.69 & 74.4 & 3.49 & 75.6 & 0.45 \\
\hline $\mathrm{TiO}_{2}$ & 0.44 & 0.33 & 0.17 & 0.10 & 0.34 & 0.21 & 0.29 & 0.10 & 0.42 & 0.28 & 0.19 & 0.07 \\
\hline $\mathrm{Al}_{2} \mathrm{O}_{3}$ & 14.2 & 1.93 & 13.4 & 0.82 & 14.1 & 0.47 & 13.7 & 0.59 & 13.3 & 1.04 & 13.1 & 0.23 \\
\hline $\mathrm{FeO}^{\mathrm{j}}$ & 2.17 & 1.08 & 2.13 & 0.32 & 3.04 & 0.27 & 2.45 & 0.30 & 2.18 & 1.05 & 2.21 & 0.23 \\
\hline MgO & 0.52 & 0.48 & 0.12 & 0.05 & 0.24 & 0.09 & 0.23 & 0.05 & 0.48 & 0.40 & 0.10 & 0.05 \\
\hline $\mathrm{CaO}$ & 1.96 & 1.23 & 1.29 & 0.18 & 1.77 & 0.36 & 1.57 & 0.21 & 2.06 & 1.12 & 1.25 & 0.15 \\
\hline $\mathrm{Na}_{2} \mathrm{O}$ & 4.56 & 0.96 & 3.87 & 0.44 & 4.39 & 0.27 & 4.12 & 0.31 & 4.03 & 0.38 & 4.31 & 0.33 \\
\hline $\mathrm{K}_{2} \mathrm{O}$ & 2.85 & 1.02 & 2.75 & 0.29 & 2.74 & 0.27 & 2.89 & 0.41 & 2.59 & 1.07 & 3.02 & 0.24 \\
\hline $\mathrm{Cl}$ & 0.37 & 0.25 & 0.17 & 0.06 & 0.16 & 0.05 & 0.16 & 0.08 & 0.49 & 0.21 & 0.18 & 0.06 \\
\hline Total $^{k}$ & 93.35 & 3.39 & 93.89 & 3.66 & 92.41 & 1.18 & 92.91 & 1.31 & 94.90 & 1.08 & 95.72 & 1.59 \\
\hline
\end{tabular}

Table A2: continued. 


\begin{tabular}{|c|c|c|c|c|c|c|}
\hline Sample number ${ }^{a}$ & M-58 (2) & M-59 & M-60 & M-61 (1) & M-61 (2) & M-62 \\
\hline \multicolumn{7}{|c|}{ Sample correlative $^{b}$} \\
\hline Sample details ${ }^{c}$ & $1124 \mathrm{C}-15 \mathrm{H}-5$ & $1124 \mathrm{C}-15 \mathrm{H}-6$ & $1124 \mathrm{C}-16 \mathrm{H}-2$ & $1124 \mathrm{C}-16 \mathrm{H}-2$ & $1124 \mathrm{C}-16 \mathrm{H}-2$ & $1124 \mathrm{C}-16 \mathrm{H}-2$ \\
\hline Base $^{\text {d }}$ & $71 \mathrm{~cm}$ & $38 \mathrm{~cm}$ & $20 \mathrm{~cm}$ & $64 \mathrm{~cm}$ & $64 \mathrm{~cm}$ & $118 \mathrm{~cm}$ \\
\hline $\mathrm{mbsf}^{\mathrm{e}}$ & $147.91 \mathrm{~m}$ & $149.08 \mathrm{~m}$ & $152.40 \mathrm{~m}$ & $152.84 \mathrm{~m}$ & $152.84 \mathrm{~m}$ & $153.38 \mathrm{~m}$ \\
\hline Age (Ma) & 7.220 & 7.280 & 7.550 & 7.580 & 7.580 & 7.590 \\
\hline$n^{f}$ & 6 & 18 & 17 & 12 & 7 & 12 \\
\hline
\end{tabular}

\begin{tabular}{|c|c|c|c|c|c|c|c|c|c|c|c|c|}
\hline EPMA & Mean $^{\mathrm{g}}$ & $2 s d^{h}$ & & & & & & & & & & \\
\hline $\mathrm{SiO}_{2}(\text { wt. } \%)^{\mathrm{i}}$ & 76.9 & 0.32 & 77.2 & 0.90 & 76.1 & 0.83 & 75.3 & 0.55 & 76.3 & 0.59 & 77.4 & 1.15 \\
\hline $\mathrm{TiO}_{2}$ & 0.18 & 0.06 & 0.08 & 0.10 & 0.33 & 0.09 & 0.29 & 0.07 & 0.14 & 0.07 & 0.17 & 0.14 \\
\hline $\mathrm{Al}_{2} \mathrm{O}_{3}$ & 12.8 & 0.25 & 12.8 & 0.57 & 13.5 & 0.47 & 13.9 & 0.12 & 13.1 & 0.35 & 13.1 & 0.65 \\
\hline $\mathrm{FeO}^{\mathrm{j}}$ & 1.57 & 0.24 & 1.11 & 0.34 & 1.44 & 0.19 & 1.64 & 0.32 & 1.65 & 0.18 & 1.77 & 0.49 \\
\hline $\mathrm{MgO}$ & 0.14 & 0.10 & 0.07 & 0.05 & 0.30 & 0.05 & 0.30 & 0.06 & 0.06 & 0.05 & 0.13 & 0.14 \\
\hline $\mathrm{CaO}$ & 1.08 & 0.13 & 0.73 & 0.31 & 1.13 & 0.09 & 1.36 & 0.17 & 1.08 & 0.14 & 1.42 & 0.29 \\
\hline $\mathrm{Na}_{2} \mathrm{O}$ & 3.97 & 0.28 & 3.50 & 0.42 & 4.65 & 0.41 & 4.57 & 0.38 & 3.75 & 0.24 & 2.80 & 1.01 \\
\hline $\mathrm{K}_{2} \mathrm{O}$ & 3.19 & 0.37 & 4.37 & 0.92 & 2.32 & 0.19 & 2.34 & 0.71 & 3.74 & 0.30 & 3.08 & 0.40 \\
\hline $\mathrm{Cl}$ & 0.23 & 0.08 & 0.14 & 0.06 & 0.18 & 0.06 & 0.19 & 0.06 & 0.15 & 0.04 & 0.13 & 0.07 \\
\hline Total $^{k}$ & 95.58 & 1.54 & 93.36 & 3.30 & 94.18 & 2.53 & 93.23 & 1.91 & 92.73 & 1.05 & 95.42 & 4.51 \\
\hline
\end{tabular}

Table A2: continued. 


\begin{tabular}{|c|c|c|c|c|c|c|}
\hline Sample number ${ }^{\mathrm{a}}$ & M-63 & M-64 (1) & M-64 (2) & M-65 & M-66 & M-67 \\
\hline Sample correlative $^{b}$ & & & & & & AT-266 \\
\hline Sample details ${ }^{\mathrm{c}}$ & $1124 \mathrm{C}-16 \mathrm{H}-3$ & $1124 \mathrm{C}-16 \mathrm{H}-5$ & $1124 \mathrm{C}-16 \mathrm{H}-5$ & $1124 \mathrm{C}-17 \mathrm{X}-1$ & $1124 C-17 X-5$ & $1124 C-17 X-5$ \\
\hline Base $^{d}$ & $136.5 \mathrm{~cm}$ & $23.5 \mathrm{~cm}$ & $23.5 \mathrm{~cm}$ & $110 \mathrm{~cm}$ & $13.5 \mathrm{~cm}$ & $119 \mathrm{~cm}$ \\
\hline $\operatorname{mbsf}^{e}$ & $155.07 \mathrm{~m}$ & $156.94 \mathrm{~m}$ & $156.94 \mathrm{~m}$ & $160.30 \mathrm{~m}$ & $165.34 \mathrm{~m}$ & $166.39 \mathrm{~m}$ \\
\hline Age (Ma) & 7.660 & 7.820 & 7.820 & 8.090 & 8.370 & 8.470 \\
\hline$n^{f}$ & 17 & 14 & 4 & 19 & 18 & 18 \\
\hline
\end{tabular}

\begin{tabular}{|c|c|c|c|c|c|c|c|c|c|c|c|c|}
\hline ЕРMА & Mean $^{\mathrm{g}}$ & $2 s d^{h}$ & & & & & & & & & & \\
\hline $\mathrm{SiO}_{2}(\text { wt. } \%)^{\mathrm{i}}$ & 75.6 & 0.71 & 76.3 & 0.76 & 77.6 & 0.56 & 76.1 & 0.43 & 78.2 & 0.50 & 74.1 & 0.73 \\
\hline $\mathrm{TiO}_{2}$ & 0.30 & 0.10 & 0.18 & 0.10 & 0.17 & 0.14 & 0.26 & 0.05 & 0.14 & 0.04 & 0.33 & 0.09 \\
\hline $\mathrm{Al}_{2} \mathrm{O}_{3}$ & 13.5 & 0.34 & 13.2 & 0.53 & 12.3 & 0.24 & 13.7 & 0.33 & 12.5 & 0.37 & 13.9 & 0.49 \\
\hline $\mathrm{FeO}^{\mathrm{j}}$ & 1.79 & 0.30 & 1.68 & 0.23 & 1.37 & 0.23 & 1.48 & 0.25 & 0.96 & 0.20 & 2.14 & 0.30 \\
\hline MgO & 0.31 & 0.05 & 0.17 & 0.04 & 0.10 & 0.05 & 0.34 & 0.05 & 0.12 & 0.04 & 0.34 & 0.05 \\
\hline $\mathrm{CaO}$ & 1.45 & 0.14 & 1.22 & 0.16 & 0.95 & 0.05 & 1.56 & 0.10 & 0.78 & 0.13 & 1.72 & 0.24 \\
\hline $\mathrm{Na}_{2} \mathrm{O}$ & 4.09 & 0.32 & 3.90 & 0.34 & 3.78 & 0.25 & 4.14 & 0.19 & 3.41 & 0.49 & 4.25 & 0.30 \\
\hline $\mathrm{K}_{2} \mathrm{O}$ & 2.82 & 0.40 & 3.21 & 0.43 & 3.51 & 0.26 & 2.32 & 0.14 & 3.71 & 0.52 & 2.97 & 0.24 \\
\hline $\mathrm{Cl}$ & 0.17 & 0.05 & 0.19 & 0.05 & 0.21 & 0.03 & 0.16 & 0.06 & 0.22 & 0.08 & 0.21 & 0.05 \\
\hline Total $^{k}$ & 94.27 & 1.51 & 92.38 & 1.07 & 92.35 & 1.52 & 91.13 & 1.31 & 92.11 & 3.83 & 95.26 & 1.75 \\
\hline
\end{tabular}

Table A2: continued. 


\begin{tabular}{|c|c|c|c|c|c|c|c|c|c|c|c|c|}
\hline Sample number ${ }^{\mathrm{a}}$ & \multicolumn{2}{|l|}{ M-68 } & \multicolumn{2}{|l|}{ M-69 } & \multicolumn{2}{|c|}{ M-70 (1) } & \multicolumn{2}{|c|}{ M-70 (2) } & \multicolumn{2}{|l|}{ M-71 } & \multicolumn{2}{|c|}{ M-72 (1) } \\
\hline \multicolumn{13}{|c|}{ Sample correlative $^{b}$} \\
\hline Sample details ${ }^{\mathrm{c}}$ & \multicolumn{2}{|c|}{$1124 \mathrm{C}-17 \mathrm{X}-6$} & \multicolumn{2}{|c|}{$1124 \mathrm{C}-18 \mathrm{X}-2$} & \multicolumn{2}{|c|}{$1124 \mathrm{C}-18 \mathrm{X}-5$} & \multicolumn{2}{|c|}{$1124 \mathrm{C}-18 \mathrm{X}-5$} & \multicolumn{2}{|c|}{$1124 \mathrm{C}-18 \mathrm{X}-6$} & \multicolumn{2}{|c|}{$1124 C-18 X-6$} \\
\hline Base $^{d}$ & \multicolumn{2}{|l|}{$104 \mathrm{~cm}$} & \multicolumn{2}{|c|}{$130 \mathrm{~cm}$} & \multicolumn{2}{|c|}{$140 \mathrm{~cm}$} & \multicolumn{2}{|c|}{$140 \mathrm{~cm}$} & \multicolumn{2}{|c|}{$119 \mathrm{~cm}$} & \multicolumn{2}{|c|}{$150 \mathrm{~cm}$} \\
\hline $\operatorname{mbsf}^{e}$ & \multicolumn{2}{|c|}{$167.74 \mathrm{~m}$} & \multicolumn{2}{|c|}{$171.60 \mathrm{~m}$} & \multicolumn{2}{|c|}{$176.20 \mathrm{~m}$} & \multicolumn{2}{|c|}{$176.20 \mathrm{~m}$} & \multicolumn{2}{|c|}{$177.49 \mathrm{~m}$} & \multicolumn{2}{|c|}{$177.80 \mathrm{~m}$} \\
\hline Age (Ma) & \multicolumn{2}{|l|}{8.610} & \multicolumn{2}{|l|}{8.890} & \multicolumn{2}{|l|}{9.180} & \multicolumn{2}{|l|}{9.180} & \multicolumn{2}{|l|}{9.260} & \multicolumn{2}{|l|}{9.280} \\
\hline$n^{f}$ & \multicolumn{2}{|l|}{18} & \multicolumn{2}{|l|}{17} & \multicolumn{2}{|l|}{12} & 9 & & 18 & & 11 & \\
\hline EPMA & Mean $^{\mathrm{g}}$ & $2 s d^{h}$ & & & & & & & & & & \\
\hline $\mathrm{SiO}_{2}(\text { wt. } \%)^{\mathrm{i}}$ & 77.1 & 0.73 & 77.0 & 0.77 & 72.9 & 0.44 & 76.0 & 0.75 & 75.6 & 0.79 & 76.5 & 1.16 \\
\hline $\mathrm{TiO}_{2}$ & 0.14 & 0.07 & 0.20 & 0.10 & 0.43 & 0.13 & 0.18 & 0.10 & 0.21 & 0.09 & 0.18 & 0.14 \\
\hline $\mathrm{Al}_{2} \mathrm{O}_{3}$ & 12.6 & 0.43 & 12.9 & 0.63 & 14.7 & 0.27 & 13.5 & 0.48 & 13.4 & 0.38 & 12.8 & 0.75 \\
\hline $\mathrm{FeO}^{\mathrm{j}}$ & 1.39 & 0.27 & 1.22 & 0.25 & 2.36 & 0.23 & 1.41 & 0.37 & 1.71 & 0.23 & 1.58 & 0.28 \\
\hline MgO & 0.10 & 0.05 & 0.17 & 0.06 & 0.48 & 0.08 & 0.16 & 0.10 & 0.18 & 0.05 & 0.08 & 0.05 \\
\hline $\mathrm{CaO}$ & 0.93 & 0.19 & 1.06 & 0.16 & 1.99 & 0.16 & 0.93 & 0.25 & 1.14 & 0.18 & 0.72 & 0.18 \\
\hline $\mathrm{Na}_{2} \mathrm{O}$ & 4.10 & 0.26 & 3.55 & 0.41 & 4.60 & 0.27 & 4.33 & 0.29 & 4.65 & 0.36 & 4.45 & 0.38 \\
\hline $\mathrm{K}_{2} \mathrm{O}$ & 3.42 & 0.34 & 3.77 & 0.34 & 2.36 & 0.16 & 3.32 & 0.27 & 2.87 & 0.21 & 3.47 & 0.30 \\
\hline $\mathrm{Cl}$ & 0.21 & 0.08 & 0.15 & 0.06 & 0.19 & 0.09 & 0.21 & 0.06 & 0.20 & 0.06 & 0.24 & 0.08 \\
\hline Total $^{\mathrm{k}}$ & 93.49 & 2.22 & 94.16 & 2.57 & 92.30 & 2.20 & 92.99 & 2.57 & 91.74 & 1.12 & 92.78 & 2.38 \\
\hline
\end{tabular}

Table A2: continued. 


\begin{tabular}{ll}
\hline $\begin{array}{ll}\text { Sample number } \\
\text { Sample correlative }\end{array}$ & M-72 (2) \\
Sample details $^{\mathrm{c}}$ & $1124 \mathrm{C}-18 \mathrm{X}-6$ \\
Base $^{\mathrm{d}}$ & $150 \mathrm{~cm}$ \\
mbsf $^{\mathrm{e}}$ & $177.80 \mathrm{~m}$ \\
Age (Ma) $_{\text {f }}^{\mathrm{f}}$ & 9.280 \\
\hline \hline
\end{tabular}

$\begin{array}{lll}\text { EPMA } & \text { Mean }^{\mathrm{g}} & 2 s d^{h} \\ \mathrm{SiO}_{2} \text { (wt. \%) } & \mathbf{7 4 . 9} & 1.07 \\ \mathrm{TiO}_{2} & \mathbf{0 . 2 1} & 0.09 \\ \mathrm{Al}_{2} \mathrm{O}_{3} & \mathbf{1 3 . 7} & 0.54 \\ \mathrm{FeO}^{\mathrm{j}} & \mathbf{1 . 9 5} & 0.27 \\ \mathrm{MgO} & \mathbf{0 . 1 7} & 0.05 \\ \mathrm{CaO} & \mathbf{1 . 0 9} & 0.15 \\ \mathrm{Na}_{2} \mathrm{O} & \mathbf{4 . 7 6} & 0.25 \\ \mathrm{~K}_{2} \mathrm{O} & \mathbf{3 . 1 2} & 0.43 \\ \mathrm{Cl} & \mathbf{0 . 1 8} & 0.07 \\ \text { Total }^{\mathrm{k}} & \mathbf{9 1 . 9 8} & 1.79\end{array}$

Table A2: continued. Analyses were performed on a WDS JEOL 733 Superprobe at VUW, NZ (20 $\mu \mathrm{m}$ beam, $15 \mathrm{keV}, 8 \mathrm{nA}) .{ }^{\text {a }}$ Samples with multiple glass populations are presented separately - e.g. M-2 (1) and M-2 (2). ${ }^{\mathrm{b}}$ Samples prefixed "AT-" were previously assigned by Carter et al. (2004). ${ }^{\mathrm{c}}$ Core details e.g. $1124 \mathrm{C}-7 \mathrm{H}-3=$ Site 1124 , hole $\mathrm{C}$, core 7 , core type $\left(\mathrm{H}=\right.$ hydraulic piston), section $3 .{ }^{\mathrm{d}}$ Depth to base of ash $(\mathrm{cm})$ in relevant core section. ${ }^{\mathrm{e}}$ Depth to base of tephra in metres below sea floor in the corresponding hole. ${ }^{\mathrm{f}}$ Number of analyses. ${ }^{\mathrm{g}}$ Mean of $\mathrm{n}$ analyses. ${ }^{\mathrm{h}} \pm 2$ standard deviations in wt. $\%$. ${ }^{\mathrm{i}}$ Mean composition in wt. \% recalculated to $100 \%$. ${ }^{\mathrm{j}} \mathrm{Fe}$ reported as FeO. ${ }^{\mathrm{k}}$ Mean analytical totals of EPMA analyses. 


\section{Appendix Three}

\section{Trace Element Data}

Table A3. Mean trace element composition of glass shards from tephra layers analysed in this study as measured by laser ablation inductively coupled plasma mass spectrometry (LA-ICP-MS). 


\begin{tabular}{|c|c|c|c|c|c|c|c|c|c|c|c|}
\hline Sample number ${ }^{a}$ & \multicolumn{2}{|l|}{ M-1 } & \multicolumn{2}{|c|}{ M-2 (1) } & \multicolumn{2}{|c|}{ M-2 (2) } & \multicolumn{2}{|l|}{ M-3 } & \multicolumn{2}{|l|}{ M-4 (1) } & M-4 (2) \\
\hline Sample correlative $^{\mathrm{b}}$ & \multicolumn{2}{|l|}{ AT-503 } & \multicolumn{2}{|c|}{ AT-313 } & \multicolumn{2}{|c|}{ AT-313 } & \multicolumn{2}{|c|}{ AT-504 } & \multicolumn{2}{|l|}{ AT-326 } & AT-326 \\
\hline Sample details ${ }^{\mathrm{c}}$ & \multicolumn{2}{|c|}{$1124 \mathrm{C}-7 \mathrm{H}-3$} & \multicolumn{2}{|c|}{$1124 \mathrm{C}-7 \mathrm{H}-3$} & \multicolumn{2}{|c|}{$1124 \mathrm{C}-7 \mathrm{H}-3$} & \multicolumn{2}{|c|}{$1124 \mathrm{C}-7 \mathrm{H}-4$} & $1124 \mathrm{C}-7$ & H-4 & $1124 \mathrm{C}-7 \mathrm{H}-4$ \\
\hline Base $^{\text {d }}$ & $73 \mathrm{~cm}$ & & $120 \mathrm{~cm}$ & & $120 \mathrm{~cm}$ & & $64 \mathrm{~cm}$ & & $90 \mathrm{~cm}$ & & $90 \mathrm{~cm}$ \\
\hline $\operatorname{mbsf}^{e}$ & $68.93 \mathrm{~m}$ & & $69.40 \mathrm{n}$ & & $69.40 \mathrm{~m}$ & & $70.34 n$ & & $70.60 \mathrm{~m}$ & & $70.60 \mathrm{~m}$ \\
\hline Age (Ma) & 2.145 & & 2.165 & & 2.165 & & 2.205 & & 2.216 & & 2.216 \\
\hline $\mathrm{n}^{\mathrm{f}}$ & 16 & & 9 & & 6 & & 15 & & 12 & & 0 \\
\hline LA-ICP-MS & Mean $^{\mathrm{g}}$ & $2 s d^{h}$ & & & & & & & & & \\
\hline $\mathrm{Li}(\mathrm{ppm})^{\mathrm{i}}$ & nd & & 56.9 & 14.3 & 56.0 & 13.2 & 51.7 & 27.9 & 58.2 & 12.4 & \\
\hline B & nd & & 34.2 & 2.11 & 28.7 & 6.39 & 35.7 & 4.85 & 31.4 & 4.26 & \\
\hline Mg & 1270 & 1210 & 435 & 108 & 526 & 204 & 813 & 233 & 1400 & 495 & \\
\hline $\mathrm{Si}$ & nd & & 78.1 & 0.55 & 78.0 & 0.41 & 77.5 & 0.59 & 74.2 & 1.22 & \\
\hline $\mathrm{Ca}$ & 0.98 & 0.29 & 0.89 & 0.20 & 0.98 & 0.12 & 1.08 & 0.28 & 1.69 & 0.32 & \\
\hline $\mathrm{Sc}$ & 11.6 & 3.37 & 12.1 & 1.73 & 13.0 & 0.60 & 6.13 & 1.40 & 16.1 & 3.46 & \\
\hline $\mathrm{Ti}$ & 866 & 553 & 577 & 64.8 & 709 & 91.5 & 728 & 123 & 1410 & 233 & \\
\hline V & 1.85 & 2.23 & 0.61 & 0.79 & 0.52 & 0.23 & 2.75 & 1.47 & 1.57 & 1.82 & \\
\hline $\mathrm{Cr}$ & bd & & 1.25 & 5.71 & 0.06 & 2.71 & 0.72 & 7.80 & 0.91 & 2.17 & \\
\hline Mn & 399 & 160 & 268 & 17.8 & 331 & 36.3 & 245 & 33.9 & 487 & 94.4 & \\
\hline $\mathrm{Ni}$ & 5.60 & 15.6 & bd & & 0.16 & 1.52 & 0.34 & 4.25 & 1.10 & 3.12 & \\
\hline $\mathrm{Cu}$ & 13.3 & 24.9 & 3.88 & 2.58 & 5.62 & 4.68 & 4.60 & 8.74 & 9.06 & 6.30 & \\
\hline $\mathrm{Zn}$ & 38.5 & 24.0 & 40.0 & 9.51 & 45.5 & 15.9 & 24.6 & 17.8 & 49.5 & 27.4 & \\
\hline $\mathbf{R b}$ & 127 & 42.8 & 135 & 16.8 & 125 & 5.60 & 142 & 11.9 & 110 & 8.88 & \\
\hline $\mathrm{Sr}$ & 70.6 & 30.3 & 48.7 & 4.55 & 62.0 & 8.80 & 72.1 & 23.7 & 114 & 24.7 & \\
\hline $\mathbf{Y}$ & 31.7 & 7.88 & 31.5 & 4.54 & 32.6 & 4.56 & 21.1 & 9.06 & 34.5 & 10.5 & \\
\hline $\mathrm{Zr}$ & 177 & 87.3 & 111 & 8.85 & 153 & 25.8 & 105 & 44.2 & 272 & 73.1 & \\
\hline $\mathrm{Nb}$ & 8.72 & 2.76 & 8.41 & 1.48 & 8.88 & 1.02 & 6.16 & 1.05 & 9.59 & 0.59 & \\
\hline Cs & 5.83 & 1.87 & 7.00 & 0.53 & 6.17 & 0.35 & 7.41 & 1.01 & 5.78 & 0.51 & \\
\hline $\mathrm{Ba}$ & 817 & 251 & 900 & 66.5 & 847 & 81.6 & 858 & 109 & 747 & 91.2 & \\
\hline La & 25.8 & 5.94 & 27.3 & 2.44 & 26.8 & 5.42 & 25.0 & 7.90 & 25.3 & 6.61 & \\
\hline $\mathrm{Ce}$ & 51.6 & 15.3 & 55.9 & 3.33 & 53.6 & 2.57 & 49.2 & 5.17 & 54.8 & 3.59 & \\
\hline Pr & 5.59 & 1.42 & 6.15 & 0.67 & 5.89 & 0.50 & 4.93 & 1.31 & 6.37 & 1.21 & \\
\hline Nd & 22.9 & 5.74 & 24.0 & 2.08 & 23.7 & 4.49 & 18.7 & 5.18 & 26.8 & 5.16 & \\
\hline Sm & 5.05 & 1.37 & 5.14 & 1.02 & 5.17 & 1.46 & 3.26 & 1.71 & 5.92 & 1.63 & \\
\hline $\mathbf{E u}$ & 0.63 & 0.32 & 0.52 & 0.22 & 0.53 & 0.13 & 0.46 & 0.18 & 0.90 & 0.27 & \\
\hline Gd & 4.95 & 1.50 & 4.83 & 1.05 & 5.03 & 0.83 & 3.11 & 1.94 & 5.81 & 1.74 & \\
\hline Tb & 0.82 & 0.22 & 0.83 & 0.40 & 0.85 & 0.40 & 0.56 & 0.30 & 0.87 & 0.26 & \\
\hline Dy & 5.68 & 1.69 & 5.40 & 0.88 & 5.58 & 1.51 & 3.46 & 2.07 & 5.94 & 1.96 & \\
\hline Нo & 1.07 & 0.33 & 1.10 & 0.18 & 1.23 & 0.43 & 0.72 & 0.38 & 1.27 & 0.44 & \\
\hline $\mathrm{Er}$ & 3.38 & 1.07 & 3.06 & 1.39 & 3.49 & 0.42 & 2.16 & 0.93 & 3.82 & 1.33 & \\
\hline Tm & 0.49 & 0.15 & 0.48 & 0.11 & 0.53 & 0.19 & 0.37 & 0.14 & 0.59 & 0.20 & \\
\hline $\mathrm{Yb}$ & 3.47 & 1.25 & 3.51 & 0.56 & 3.92 & 1.11 & 2.46 & 0.99 & 4.01 & 1.46 & \\
\hline Lu & 0.57 & 0.17 & 0.57 & 0.14 & 0.60 & 0.38 & 0.42 & 0.17 & 0.58 & 0.20 & \\
\hline Hf & 4.88 & 2.06 & 3.98 & 0.68 & 4.93 & 1.37 & 3.36 & 1.48 & 7.12 & 2.50 & \\
\hline Ta & 0.77 & 0.27 & 0.89 & 0.10 & 0.83 & 0.12 & 0.74 & 0.36 & 0.76 & 0.12 & \\
\hline W & 1.54 & 0.94 & 2.47 & 2.47 & 2.07 & 1.25 & 1.68 & 0.95 & 1.60 & 0.41 & \\
\hline $\mathrm{Pb}$ & 21.2 & 5.11 & 20.8 & 1.87 & 20.0 & 1.22 & 20.1 & 2.05 & 21.6 & 2.90 & \\
\hline Th & 12.8 & 3.69 & 14.5 & 1.61 & 13.5 & 1.84 & 14.4 & 4.74 & 10.8 & 2.77 & \\
\hline $\mathbf{U}$ & 2.59 & 0.74 & 3.02 & 0.44 & 2.81 & 0.24 & 3.14 & 0.59 & 2.44 & 0.25 & \\
\hline $\mathrm{Rb} / \mathrm{Sr}$ & 1.83 & 0.53 & 2.79 & 0.52 & 2.03 & 0.27 & 2.03 & 0.71 & 0.97 & 0.24 & \\
\hline $\mathrm{Sr} / \mathrm{Y}$ & 2.22 & 0.65 & 1.55 & 0.13 & 1.90 & 0.09 & 3.48 & 1.01 & 3.37 & 1.09 & \\
\hline $\mathrm{Zr} / \mathrm{Th}$ & 13.7 & 3.94 & 7.66 & 0.53 & 11.3 & 0.66 & 7.31 & 1.80 & 25.1 & 1.59 & \\
\hline $\mathbf{E u} / \mathbf{E} \mathbf{u}^{*}$ & 0.39 & 0.24 & 0.32 & 0.15 & 0.32 & 0.07 & 0.47 & 0.29 & 0.48 & 0.13 & \\
\hline $\mathrm{Zr} / \mathrm{Y}$ & 5.53 & 1.98 & 3.52 & 0.35 & 4.70 & 0.34 & 5.02 & 1.11 & 7.90 & 0.44 & \\
\hline $\mathrm{Ba} / \mathrm{Sr}$ & 11.8 & 3.88 & 18.5 & 2.25 & 13.7 & 1.77 & 12.1 & 3.43 & 6.58 & 1.34 & \\
\hline $\mathrm{Nb} / \mathrm{Pb}$ & 0.41 & 0.13 & 0.40 & 0.07 & 0.44 & 0.06 & 0.30 & 0.04 & 0.44 & 0.06 & \\
\hline $\mathrm{La} / \mathrm{Yb}$ & 7.61 & 2.65 & 7.78 & 0.98 & 6.92 & 1.50 & 10.4 & 4.01 & 6.39 & 1.18 & \\
\hline Dy/Yb & 1.69 & 0.86 & 1.54 & 0.16 & 1.44 & 0.48 & 1.42 & 0.62 & 1.49 & 0.24 & \\
\hline $\mathrm{Ba} / \mathrm{Th}$ & 64.3 & 15.9 & 62.4 & 7.34 & 62.9 & 7.97 & 60.6 & 13.9 & 69.4 & 10.3 & \\
\hline
\end{tabular}

Table A3: Mean trace element composition of glass shards from tephra layers analysed in this thesis as measured by laser ablation inductively coupled plasma mass spectrometry (LA-ICP-MS). 


\begin{tabular}{|c|c|c|c|c|c|c|c|c|c|c|c|c|}
\hline Sample number ${ }^{a}$ & \multicolumn{2}{|l|}{ M-5 } & \multicolumn{2}{|l|}{ M-6 } & \multicolumn{2}{|l|}{ M-7 } & \multicolumn{2}{|l|}{ M-8 } & \multicolumn{2}{|c|}{ M-9 (1) } & \multicolumn{2}{|c|}{ M-9 (2) } \\
\hline \multicolumn{13}{|l|}{ Sample correlative ${ }^{b}$} \\
\hline Sample details ${ }^{c}$ & \multicolumn{2}{|c|}{$1124 \mathrm{C}-7 \mathrm{H}-5$} & \multicolumn{2}{|c|}{$1124 \mathrm{C}-7 \mathrm{H}-5$} & \multicolumn{2}{|c|}{$1124 \mathrm{C}-7 \mathrm{H}-6$} & \multicolumn{2}{|c|}{$1124 \mathrm{C}-7 \mathrm{H}-6$} & \multicolumn{2}{|c|}{$1124 \mathrm{C}-8 \mathrm{H}-1$} & \multicolumn{2}{|c|}{$1124 \mathrm{C}-8 \mathrm{H}-1$} \\
\hline Base $^{d}$ & \multicolumn{2}{|l|}{$19 \mathrm{~cm}$} & $95 \mathrm{~cm}$ & & $137 \mathrm{cn}$ & & $146 \mathrm{~cm}$ & & $109 \mathrm{~cm}$ & & $109 \mathrm{~cm}$ & \\
\hline mbsf $^{e}$ & $71.39 \mathrm{~m}$ & & $72.15 n$ & & 74.071 & & $74.16 \mathrm{~m}$ & & 75.791 & & 75.791 & \\
\hline Age (Ma) & 2.250 & & 2.283 & & 2.365 & & 2.369 & & 2.433 & & 2.433 & \\
\hline$n^{f}$ & 7 & & 9 & & 10 & & 10 & & 3 & & 7 & \\
\hline LA-ICP-MS & Mean $^{\mathrm{g}}$ & $2 s d^{h}$ & & & & & & & & & & \\
\hline $\mathrm{Li}(\mathrm{ppm})^{\mathrm{i}}$ & 49.5 & 24.0 & 52.9 & 19.0 & 56.9 & 14.1 & 40.9 & 17.1 & 55.2 & 21.1 & 49.5 & 10.4 \\
\hline B & 39.7 & 9.87 & 40.0 & 12.9 & 31.2 & 3.60 & 27.3 & 7.19 & 39.8 & 3.40 & 35.5 & 13.3 \\
\hline $\mathrm{Mg}$ & 718 & 141 & 730 & 109 & 829 & 252 & 1750 & 989 & 1230 & 565 & 1842 & 182 \\
\hline $\mathrm{Si}$ & 76.9 & 0.52 & 77.0 & 0.33 & 76.3 & 0.72 & 76.1 & 0.76 & 77.1 & 0.36 & 76.9 & 0.51 \\
\hline $\mathrm{Ca}$ & 1.15 & 0.62 & 0.91 & 0.25 & 1.07 & 0.25 & 1.48 & 0.35 & 1.10 & 0.50 & 1.35 & 0.72 \\
\hline Sc & 3.09 & 4.48 & 5.19 & 2.15 & 10.9 & 1.55 & 8.98 & 4.34 & 7.54 & 3.78 & 9.47 & 3.81 \\
\hline $\mathrm{Ti}$ & 420 & 49.0 & 581 & 58.8 & 936 & 133 & 1270 & 454 & 869 & 143 & 1352 & 870 \\
\hline V & 1.79 & 2.37 & 1.75 & 1.99 & 0.96 & 0.56 & 3.57 & 5.68 & 4.49 & 2.12 & 10.9 & 9.03 \\
\hline $\mathrm{Cr}$ & bd & & 0.72 & 15.8 & bd & & 1.64 & 15.2 & bd & & 0.93 & 6.89 \\
\hline Mn & 418 & 61.3 & 243 & 30.1 & 309 & 55.4 & 440 & 119 & 245 & 34.8 & 261 & 52.5 \\
\hline $\mathrm{Ni}$ & 5.43 & 11.5 & 4.66 & 7.47 & 0.07 & 1.30 & 2.05 & 4.81 & 3.87 & 5.04 & 0.63 & 3.01 \\
\hline $\mathrm{Cu}$ & 10.4 & 34.5 & 8.57 & 12.7 & 3.90 & 2.42 & 22.7 & 52.8 & 25.5 & 61.8 & 10.7 & 12.5 \\
\hline $\mathrm{Zn}$ & 27.4 & 18.9 & 32.7 & 10.2 & 43.7 & 15.1 & 40.4 & 19.7 & 21.7 & 20.7 & 26.8 & 15.9 \\
\hline Rb & 137 & 9.7 & 156 & 22.3 & 126 & 12.9 & 129 & 10.9 & 154 & 5.27 & 128 & 53.3 \\
\hline $\mathrm{Sr}$ & 71.6 & 7.28 & 54.7 & 8.53 & 69.1 & 16.6 & 119 & 38.4 & 72.7 & 9.39 & 75.8 & 39.5 \\
\hline $\mathbf{Y}$ & 14.3 & 3.59 & 19.0 & 2.31 & 26.2 & 3.50 & 25.0 & 10.7 & 14.5 & 4.42 & 17.8 & 6.39 \\
\hline $\mathrm{Zr}$ & 69.9 & 15.7 & 83.7 & 14.1 & 160 & 36.8 & 186 & 42.9 & 96.4 & 26.1 & 149 & 85.5 \\
\hline $\mathrm{Nb}$ & 5.76 & 2.53 & 6.36 & 2.02 & 8.46 & 1.02 & 8.39 & 2.44 & 5.69 & 1.64 & 6.09 & 1.43 \\
\hline Cs & 6.05 & 1.17 & 8.29 & 2.20 & 6.71 & 0.77 & 6.21 & 1.06 & 7.83 & 0.23 & 6.43 & 2.34 \\
\hline $\mathrm{Ba}$ & 755 & 78.9 & 899 & 88.1 & 764 & 68.2 & 845 & 87.4 & 953 & 39.6 & 803 & 94.0 \\
\hline La & 21.8 & 4.83 & 23.3 & 3.17 & 22.1 & 2.42 & 24.0 & 4.22 & 21.1 & 3.89 & 19.5 & 3.83 \\
\hline $\mathrm{Ce}$ & 41.6 & 7.36 & 50.7 & 8.30 & 49.9 & 5.12 & 49.9 & 10.1 & 42.3 & 2.20 & 42.0 & 8.17 \\
\hline $\mathrm{Pr}$ & 3.68 & 1.59 & 4.82 & 0.97 & 5.30 & 0.52 & 5.48 & 2.15 & 4.29 & 1.55 & 4.57 & 0.69 \\
\hline Nd & 14.2 & 4.00 & 16.9 & 4.72 & 20.6 & 2.61 & 20.2 & 6.90 & 14.0 & 2.49 & 15.9 & 4.46 \\
\hline $\mathrm{Sm}$ & 2.50 & 2.16 & 2.92 & 1.30 & 4.44 & 1.20 & 4.21 & 3.07 & 2.75 & 0.85 & 3.04 & 1.94 \\
\hline Eu & 0.01 & 0.66 & 0.27 & 0.28 & 0.66 & 0.24 & 0.67 & 0.47 & 0.45 & 0.22 & 0.39 & 0.36 \\
\hline Gd & 1.51 & 3.17 & 2.12 & 1.29 & 4.16 & 0.93 & 4.03 & 1.89 & 1.96 & 0.93 & 3.35 & 3.10 \\
\hline Tb & 0.22 & 0.28 & 0.38 & 0.28 & 0.67 & 0.14 & 0.63 & 0.39 & 0.39 & 0.21 & 0.47 & 0.20 \\
\hline Dy & 2.33 & 1.66 & 2.67 & 1.81 & 4.57 & 0.80 & 4.21 & 2.12 & 2.44 & 1.32 & 3.24 & 1.02 \\
\hline Но & 0.43 & 0.68 & 0.59 & 0.23 & 0.96 & 0.17 & 0.95 & 0.66 & 0.43 & 0.24 & 0.62 & 0.34 \\
\hline Er & 1.35 & 2.07 & 2.01 & 1.06 & 2.75 & 0.75 & 2.77 & 1.83 & 1.49 & 1.52 & 2.02 & 0.82 \\
\hline $\mathrm{Tm}$ & 0.07 & 0.39 & 0.30 & 0.15 & 0.40 & 0.07 & 0.41 & 0.32 & 0.28 & 0.19 & 0.29 & 0.15 \\
\hline Yb & 2.37 & 2.24 & 2.12 & 1.51 & 2.91 & 1.21 & 3.11 & 1.27 & 1.55 & 1.01 & 2.41 & 0.58 \\
\hline Lu & 0.18 & 0.33 & 0.35 & 0.13 & 0.42 & 0.11 & 0.39 & 0.21 & 0.31 & 0.09 & 0.42 & 0.17 \\
\hline Hf & 3.02 & 1.38 & 2.90 & 1.45 & 4.60 & 0.90 & 5.00 & 1.45 & 3.05 & 1.44 & 4.02 & 1.28 \\
\hline Ta & 0.56 & 0.65 & 0.66 & 0.45 & 0.75 & 0.16 & 0.91 & 0.45 & 0.47 & 0.14 & 0.65 & 0.27 \\
\hline W & 2.07 & 2.15 & 1.89 & 2.21 & 1.64 & 0.45 & 1.48 & 0.82 & 1.96 & 0.53 & 1.32 & 0.81 \\
\hline $\mathrm{Pb}$ & 21.4 & 8.71 & 22.4 & 3.95 & 22.4 & 1.80 & 21.3 & 5.08 & 23.7 & 16.4 & 18.7 & 3.71 \\
\hline Th & 12.6 & 2.68 & 13.6 & 2.36 & 11.1 & 1.66 & 12.6 & 2.05 & 14.6 & 3.65 & 12.7 & 4.60 \\
\hline $\mathbf{U}$ & 2.80 & 0.91 & 3.22 & 0.88 & 2.82 & 0.38 & 2.98 & 0.71 & 3.14 & 0.28 & 3.11 & 1.37 \\
\hline $\mathrm{Rb} / \mathrm{Sr}$ & 1.91 & 0.20 & 2.86 & 0.51 & 1.85 & 0.57 & 1.11 & 0.40 & 2.13 & 0.20 & 1.47 & 0.19 \\
\hline $\mathrm{Sr} / \mathrm{Y}$ & 5.05 & 0.88 & 2.88 & 0.33 & 2.64 & 0.56 & 4.89 & 1.96 & 5.07 & 1.09 & 4.29 & 1.95 \\
\hline $\mathrm{Zr} / \mathrm{Th}$ & 5.58 & 1.01 & 6.18 & 0.86 & 14.6 & 4.26 & 14.8 & 2.75 & 6.59 & 1.01 & 12.2 & 8.08 \\
\hline $\mathbf{E u} / \mathbf{E} u^{*}$ & 0.26 & 0.50 & 0.37 & 0.51 & 0.48 & 0.22 & 0.51 & 0.28 & 0.61 & 0.30 & 0.43 & 0.54 \\
\hline $\mathrm{Zr} / \mathrm{Y}$ & 4.95 & 1.63 & 4.41 & 0.59 & 6.12 & 1.21 & 7.65 & 2.54 & 6.67 & 0.41 & 8.38 & 3.70 \\
\hline $\mathrm{Ba} / \mathrm{Sr}$ & 10.6 & 1.23 & 16.5 & 2.25 & 11.2 & 2.82 & 7.26 & 2.25 & 13.1 & 1.86 & 11.5 & 8.42 \\
\hline $\mathrm{Nb} / \mathrm{Pb}$ & 0.28 & 0.15 & 0.29 & 0.09 & 0.38 & 0.05 & 0.40 & 0.11 & 0.25 & 0.15 & 0.33 & 0.10 \\
\hline $\mathrm{La} / \mathrm{Yb}$ & 10.5 & 8.42 & 12.6 & 10.9 & 7.89 & 3.57 & 8.08 & 4.17 & 14.4 & 7.75 & 8.17 & 2.18 \\
\hline $\mathrm{Dy} / \mathrm{Yb}$ & 1.14 & 0.59 & 1.40 & 1.26 & 1.62 & 0.67 & 1.38 & 0.60 & 1.67 & 1.26 & 1.37 & 0.66 \\
\hline $\mathrm{Ba} / \mathrm{Th}$ & 60.4 & 9.15 & 66.5 & 8.74 & 69.3 & 9.62 & 67.2 & 8.29 & 65.7 & 14.9 & 64.8 & 20.4 \\
\hline
\end{tabular}

Table A3: continued. 


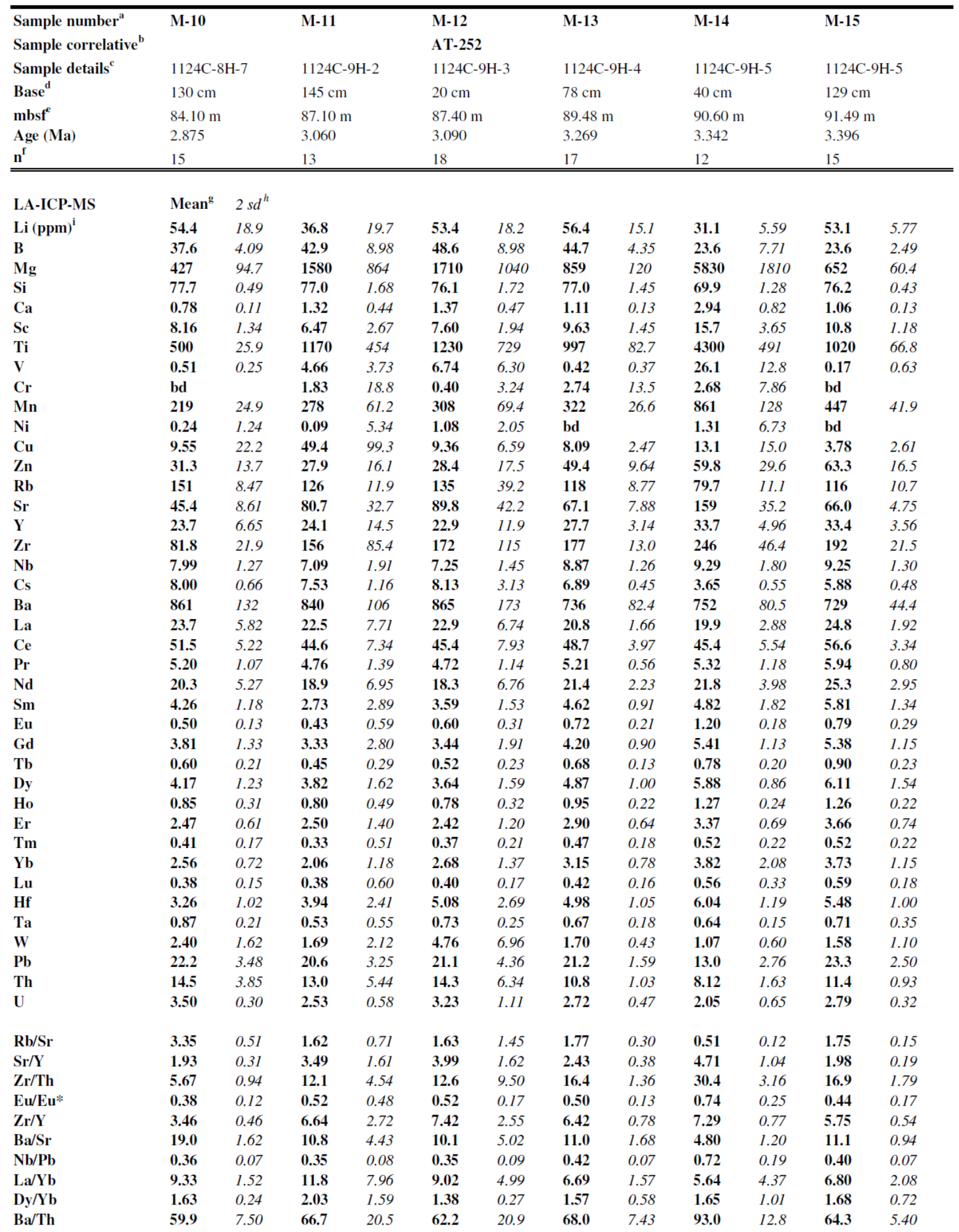

Table A3: continued. 


\begin{tabular}{|c|c|c|c|c|c|c|c|c|c|c|c|c|}
\hline Sample number ${ }^{\mathrm{a}}$ & \multicolumn{2}{|l|}{ M-16 } & \multicolumn{2}{|l|}{ M-17 } & \multicolumn{2}{|l|}{ M-18 } & \multicolumn{2}{|l|}{ M-19 } & \multicolumn{2}{|l|}{ M-20 } & \multicolumn{2}{|l|}{ M-21 } \\
\hline Sample correlative $^{\mathrm{b}}$ & \multicolumn{12}{|l|}{ AT-262 } \\
\hline Sample details ${ }^{c}$ & \multicolumn{2}{|c|}{$1124 \mathrm{C}-9 \mathrm{H}-6$} & \multicolumn{2}{|c|}{$1124 \mathrm{C}-9 \mathrm{H}-6$} & \multicolumn{2}{|c|}{$1124 \mathrm{C}-9 \mathrm{H}-7$} & \multicolumn{2}{|c|}{$1124 \mathrm{C}-10 \mathrm{H}-1$} & \multicolumn{2}{|c|}{$1124 \mathrm{C}-10 \mathrm{H}-1$} & \multicolumn{2}{|c|}{$1124 \mathrm{C}-10 \mathrm{H}-2$} \\
\hline Base $^{d}$ & \multicolumn{2}{|c|}{$71 \mathrm{~cm}$} & $133 \mathrm{~cm}$ & & $25 \mathrm{~cm}$ & & $99 \mathrm{~cm}$ & & $130 \mathrm{~cm}$ & & $51 \mathrm{~cm}$ & \\
\hline $\begin{array}{l}\text { mbsf }^{e} \\
\text { Age (Ma) }\end{array}$ & $\begin{array}{l}92.41 \mathrm{~m} \\
3.453\end{array}$ & & $\begin{array}{l}93.03 \mathrm{~m} \\
3.490\end{array}$ & & $\begin{array}{l}93.45 \mathrm{n} \\
3.516\end{array}$ & & $\begin{array}{l}94.69 \mathrm{n} \\
3.687\end{array}$ & & $\begin{array}{l}95.00 \mathrm{~m} \\
3.720\end{array}$ & & $\begin{array}{l}95,71 \mathrm{r} \\
3.753\end{array}$ & \\
\hline$n^{f}$ & 17 & & 9 & & 15 & & 14 & & 8 & & 15 & \\
\hline LA-ICP-MS & Mean $^{\mathrm{g}}$ & $2 s d^{h}$ & & & & & & & & & & \\
\hline $\mathrm{Li}(\mathrm{ppm})^{\mathrm{i}}$ & 48.3 & 11.2 & 48.1 & 16.1 & 50.7 & 9.16 & 54.6 & 9.40 & 55.7 & 17.6 & 44.0 & 9.29 \\
\hline B & 27.1 & 4.43 & 36.2 & 4.71 & 29.2 & 4.67 & 45.8 & 4.66 & 37.7 & 9.48 & 26.8 & 4.39 \\
\hline $\mathrm{Mg}$ & 514 & 151 & 1310 & 222 & 475 & 78.6 & 815 & 61.3 & 611 & 295 & 1160 & 131 \\
\hline $\mathrm{Si}$ & 76.6 & 0.67 & 76.1 & 0.69 & 76.8 & 1.34 & 75.2 & 1.11 & 77.2 & 0.37 & 75.5 & 0.51 \\
\hline $\mathrm{Ca}$ & 0.99 & 0.11 & 1.26 & 0.28 & 0.97 & 0.13 & 1.22 & 0.10 & 0.85 & 0.18 & 1.40 & 0.19 \\
\hline $\mathrm{Sc}$ & 12.1 & 1.74 & 11.3 & 2.44 & 12.4 & 1.82 & 10.7 & 1.79 & 8.57 & 1.04 & 10.0 & 1.50 \\
\hline $\mathrm{Ti}$ & 682 & 80.0 & 1220 & 160 & 804 & 60.8 & 955 & 53.8 & 548 & 169 & 1010 & 165 \\
\hline V & 0.19 & 0.90 & 4.28 & 2.13 & 0.27 & 0.40 & 0.36 & 0.46 & 1.14 & 0.78 & 0.77 & 0.61 \\
\hline $\mathrm{Cr}$ & bd & & bd & & bd & & bd & & 1.58 & 7.69 & 0.95 & 10.2 \\
\hline Mn & 385 & 60.0 & 290 & 41.6 & 334 & 34.3 & 338 & 29.8 & 235 & 68.8 & 489 & 31.0 \\
\hline $\mathrm{Ni}$ & 0.12 & 3.88 & 0.590 & 7.12 & bd & & bd & & 1.08 & 4.83 & bd & \\
\hline $\mathrm{Cu}$ & 4.80 & 7.06 & 6.31 & 8.23 & 6.90 & 7.32 & 9.35 & 3.11 & 2.76 & 2.72 & 4.15 & 4.47 \\
\hline $\mathrm{Zn}$ & 62.9 & 13.1 & 36.0 & 16.8 & 55.6 & 14.7 & 49.6 & 14.2 & 27.1 & 9.42 & 53.5 & 15.3 \\
\hline $\mathbf{R b}$ & 128 & 8.80 & 123 & 18.4 & 121 & 9.6 & 140 & 8.67 & 132 & 36.3 & 114 & 11.5 \\
\hline $\mathrm{Sr}$ & 58.0 & 6.05 & 70.5 & 11.7 & 66.7 & 8.57 & 77.3 & 6.99 & 54.5 & 16.4 & 104 & 10.4 \\
\hline$Y$ & 36.0 & 3.42 & 29.4 & 6.84 & 38.4 & 5.16 & 31.9 & 3.33 & 19.2 & 2.94 & 31.5 & 5.11 \\
\hline $\mathrm{Zr}$ & 156 & 22.6 & 186 & 45.0 & 151 & 22.6 & 235 & 28.5 & 74.3 & 20.0 & 213 & 27.5 \\
\hline $\mathrm{Nb}$ & 9.74 & 1.62 & 7.44 & 1.27 & 8.08 & 1.13 & 8.94 & 1.12 & 7.19 & 0.91 & 7.14 & 1.10 \\
\hline Cs & 6.48 & 0.80 & 6.55 & 1.66 & 6.99 & 0.87 & 8.11 & 0.62 & 7.32 & 2.37 & 5.26 & 0.64 \\
\hline $\mathrm{Ba}$ & 737 & 47.4 & 691 & 70.6 & 809 & 103 & 710 & 80.7 & 829 & 169 & 741 & 84.4 \\
\hline La & 25.2 & 2.85 & 21.6 & 4.78 & 27.5 & 4.17 & 22.5 & 2.46 & 24.4 & 4.59 & 21.4 & 2.69 \\
\hline $\mathrm{Ce}$ & 59.2 & 7.00 & 48.1 & 6.37 & 61.3 & 5.89 & 52.6 & 4.66 & 50.6 & 8.36 & 51.4 & 6.73 \\
\hline $\mathrm{Pr}$ & 6.72 & 0.99 & 5.07 & 1.26 & 6.50 & 1.13 & 5.55 & 0.73 & 4.90 & 1.19 & 5.27 & 0.88 \\
\hline Nd & 27.6 & 3.21 & 22.2 & 7.78 & 30.2 & 5.10 & 23.4 & 2.55 & 18.6 & 3.91 & 22.4 & 3.87 \\
\hline $\mathrm{Sm}$ & 5.88 & 1.37 & 3.98 & 1.57 & 6.95 & 2.20 & 4.77 & 1.41 & 3.50 & 0.74 & 4.40 & 1.60 \\
\hline Eu & 0.74 & 0.28 & 0.62 & 0.40 & 0.68 & 0.25 & 0.76 & 0.32 & 0.40 & 0.18 & 0.76 & 0.39 \\
\hline Gd & 5.75 & 1.33 & 3.96 & 1.53 & 6.05 & 2.34 & 5.20 & 1.49 & 2.91 & 1.81 & 4.10 & 1.42 \\
\hline Tb & 0.88 & 0.33 & 0.71 & 0.29 & 1.03 & 0.42 & 0.82 & 0.15 & 0.48 & 0.18 & 0.71 & 0.33 \\
\hline Dy & 5.93 & 1.45 & 5.01 & 1.97 & 6.99 & 1.86 & 5.51 & 0.94 & 3.36 & 0.68 & 5.42 & 1.72 \\
\hline Ho & 1.32 & 0.19 & 1.05 & 0.33 & 1.34 & 0.31 & 1.08 & 0.22 & 0.75 & 0.18 & 1.06 & 0.36 \\
\hline $\mathrm{Er}$ & 3.62 & 0.84 & 3.27 & 0.80 & 4.01 & 1.04 & 3.39 & 0.42 & 2.14 & 0.43 & 3.17 & 1.13 \\
\hline $\mathrm{Tm}$ & 0.57 & 0.20 & 0.48 & 0.19 & 0.61 & 0.28 & 0.54 & 0.19 & 0.33 & 0.09 & 0.52 & 0.25 \\
\hline Yb & 4.13 & 1.06 & 3.24 & 0.86 & 4.01 & 1.12 & 3.28 & 1.09 & 2.34 & 1.08 & 3.93 & 1.32 \\
\hline Lu & 0.58 & 0.19 & 0.53 & 0.35 & 0.60 & 0.21 & 0.45 & 0.21 & 0.38 & 0.29 & 0.50 & 0.25 \\
\hline Hf & 4.75 & 0.97 & 5.05 & 1.54 & 5.39 & 1.83 & 6.03 & 0.94 & 2.86 & 0.79 & 5.31 & 1.29 \\
\hline Ta & 0.80 & 0.12 & 0.68 & 0.29 & 0.75 & 0.27 & 0.68 & 0.19 & 0.79 & 0.50 & 0.57 & 0.30 \\
\hline W & 1.76 & 0.90 & 1.76 & 0.75 & 1.89 & 1.23 & 1.61 & 0.54 & 1.61 & 0.52 & 1.58 & 1.28 \\
\hline $\mathrm{Pb}$ & 25.0 & 2.98 & 20.3 & 3.73 & 27.8 & 2.86 & 22.9 & 2.56 & 19.9 & 3.97 & 19.1 & 4.20 \\
\hline Th & 11.7 & 1.30 & 10.8 & 2.48 & 13.3 & 2.27 & 12.0 & 1.33 & 13.3 & 2.62 & 11.2 & 2.25 \\
\hline $\mathbf{U}$ & 2.87 & 0.27 & 2.76 & 0.25 & 2.97 & 0.31 & 2.83 & 0.38 & 2.97 & 0.81 & 2.62 & 0.84 \\
\hline $\mathrm{Rb} / \mathrm{Sr}$ & 2.20 & 0.18 & 1.74 & 0.28 & 1.82 & 0.23 & 1.82 & 0.16 & 2.50 & 1.35 & 1.10 & 0.10 \\
\hline $\mathrm{Sr} / \mathrm{Y}$ & 1.61 & 0.15 & 2.40 & 0.27 & 1.74 & 0.18 & 2.43 & 0.24 & 2.84 & 0.78 & 3.29 & 0.37 \\
\hline $\mathrm{Zr} / \mathrm{Th}$ & 13.4 & 1.76 & 17.2 & 1.84 & 11.4 & 1.25 & 19.6 & 1.71 & 5.66 & 2.17 & 19.0 & 2.40 \\
\hline $\mathbf{E u} / \mathbf{E} u^{*}$ & 0.39 & 0.17 & 0.49 & 0.41 & 0.33 & 0.13 & 0.47 & 0.17 & 0.43 & 0.40 & 0.56 & 0.29 \\
\hline $\mathrm{Zr} / \mathrm{Y}$ & 4.34 & 0.32 & 6.32 & 0.59 & 3.93 & 0.39 & 7.39 & 0.43 & 3.87 & 0.91 & 6.76 & 0.61 \\
\hline $\mathrm{Ba} / \mathrm{Sr}$ & 12.7 & 0.98 & 9.84 & 1.13 & 12.2 & 1.77 & 9.19 & 0.72 & 15.4 & 4.28 & 7.16 & 0.61 \\
\hline $\mathrm{Nb} / \mathrm{Pb}$ & 0.39 & 0.08 & 0.37 & 0.11 & 0.29 & 0.05 & 0.39 & 0.04 & 0.36 & 0.06 & 0.38 & 0.09 \\
\hline $\mathrm{La} / \mathrm{Yb}$ & 6.22 & 2.16 & 6.70 & 1.14 & 6.95 & 1.90 & 7.03 & 2.03 & 10.8 & 4.37 & 5.60 & 2.01 \\
\hline $\mathrm{Dy} / \mathrm{Yb}$ & 1.45 & 0.32 & 1.56 & 0.62 & 1.76 & 0.55 & 1.72 & 0.59 & 1.48 & 0.53 & 1.43 & 0.77 \\
\hline $\mathrm{Ba} / \mathrm{Th}$ & 63.3 & 4.87 & 64.4 & 9.25 & 61.2 & 11.2 & 59.0 & 6.15 & 62.6 & 11.4 & 66.3 & 8.39 \\
\hline
\end{tabular}

Table A3: continued. 


\begin{tabular}{|c|c|c|c|c|c|c|c|c|c|c|c|c|}
\hline Sample number ${ }^{a}$ & \multicolumn{2}{|l|}{ M-22 } & \multicolumn{2}{|l|}{ M-23 } & \multicolumn{2}{|l|}{ M-24 } & \multicolumn{2}{|l|}{ M-25 } & \multicolumn{2}{|l|}{ M-26 } & \multicolumn{2}{|c|}{ M-27 } \\
\hline \multicolumn{13}{|l|}{ Sample correlative ${ }^{b}$} \\
\hline Sample details ${ }^{c}$ & \multicolumn{2}{|c|}{$1124 \mathrm{C}-10 \mathrm{H}-3$} & \multicolumn{2}{|c|}{$1124 \mathrm{C}-10 \mathrm{H}-3$} & \multicolumn{2}{|c|}{$1124 \mathrm{C}-10 \mathrm{H}-4$} & \multicolumn{2}{|c|}{$1124 \mathrm{C}-10 \mathrm{H}-4$} & \multicolumn{2}{|c|}{$1124 \mathrm{C}-10 \mathrm{H}-4$} & \multicolumn{2}{|c|}{$1124 \mathrm{C}-10 \mathrm{H}-6$} \\
\hline Base $^{d}$ & \multicolumn{2}{|l|}{$9 \mathrm{~cm}$} & $142 \mathrm{~cm}$ & & $9 \mathrm{~cm}$ & & $29 \mathrm{~cm}$ & & $132 \mathrm{~cm}$ & & $15 \mathrm{~cm}$ & \\
\hline $\mathrm{mbsf}^{\mathrm{e}}$ & $96.79 \mathrm{~m}$ & & $98.12 \mathrm{~m}$ & & $98.29 n$ & & 98.49 & & $99.52 \mathrm{r}$ & & 101.3 & \\
\hline Age (Ma) & 3.822 & & 3.908 & & 3.919 & & 3.930 & & 3.997 & & 4.117 & \\
\hline $\mathrm{n}^{\mathrm{f}}$ & 11 & & 8 & & 12 & & 7 & & 12 & & 16 & \\
\hline LA-ICP-MS & Mean $^{\mathrm{g}}$ & $2 s d^{h}$ & & & & & & & & & & \\
\hline $\mathrm{Li}(\mathrm{ppm})^{\mathrm{i}}$ & 48.3 & 19.7 & 39.4 & 7.59 & 26.5 & 7.19 & 61.5 & 13.0 & 23.2 & 3.40 & 52.6 & 16.4 \\
\hline B & 34.2 & 9.90 & 23.5 & 3.57 & 21.5 & 13.4 & 35.4 & 6.82 & 19.2 & 5.95 & 40.7 & 5.21 \\
\hline $\mathrm{Mg}$ & 813 & 124 & 1670 & 226 & 2940 & 782 & 674 & 80.3 & 3080 & 1680 & 210 & 20.4 \\
\hline $\mathrm{Si}$ & 77.4 & 0.48 & 73.4 & 0.44 & 73.0 & 1.75 & 77.8 & 0.67 & 73.9 & 1.95 & 77.6 & 0.32 \\
\hline $\mathrm{Ca}$ & 1.16 & 0.47 & 1.61 & 0.14 & 1.86 & 0.50 & 1.07 & 0.10 & 1.54 & 0.59 & 0.77 & 0.13 \\
\hline Sc & 8.64 & 2.78 & 14.4 & 2.28 & 15.7 & 5.11 & 7.89 & 1.74 & 11.4 & 3.55 & 9.60 & 2.34 \\
\hline $\mathrm{Ti}$ & 753 & 70.2 & 1600 & 128 & 2820 & 704 & 723 & 105 & 2860 & 1040 & 471 & 73.1 \\
\hline $\mathbf{V}$ & 0.84 & 0.98 & 0.71 & 0.60 & 6.07 & 7.48 & 1.25 & 1.87 & 12.1 & 8.38 & 0.05 & 0.75 \\
\hline $\mathrm{Cr}$ & 3.63 & 24.6 & bd & & 3.97 & 10.8 & bd & & bd & & bd & \\
\hline Mn & 419 & 34.1 & 695 & 53.2 & 888 & 110 & 353 & 47.4 & 717 & 211 & 290 & 49.0 \\
\hline $\mathrm{Ni}$ & bd & & bd & & 0.47 & 2.70 & 0.17 & 3.28 & bd & & bd & \\
\hline $\mathrm{Cu}$ & 3.74 & 6.40 & 3.93 & 3.95 & 14.7 & 10.0 & 5.54 & 7.25 & 9.72 & 15.9 & 4.22 & 5.54 \\
\hline $\mathrm{Zn}$ & 41.9 & 14.9 & 75.5 & 19.5 & 528 & 3170 & 49.3 & 18.4 & 72.1 & 17.0 & 55.4 & 16.6 \\
\hline $\mathbf{R b}$ & 118 & 16.1 & 86.6 & 5.74 & 72.6 & 12.2 & 134 & 28.5 & 57.9 & 5.86 & 137 & 13.0 \\
\hline $\mathrm{Sr}$ & 85.3 & 20.4 & 140 & 14.2 & 106 & 15.1 & 74.6 & 11.5 & 81.7 & 37.8 & 44.1 & 3.62 \\
\hline $\mathbf{Y}$ & 25.1 & 3.53 & 32.3 & 3.44 & 54.1 & 18.0 & 31.2 & 3.99 & 52.4 & 7.25 & 26.4 & 4.52 \\
\hline $\mathrm{Zr}$ & 129 & 17.4 & 228 & 29.7 & 339 & 95.3 & 131 & 31.9 & 370 & 70.6 & 97.4 & 19.9 \\
\hline $\mathrm{Nb}$ & 7.69 & 1.40 & 8.98 & 1.05 & 10.5 & 2.69 & 7.79 & 1.15 & 11.8 & 2.17 & 7.99 & 1.37 \\
\hline Cs & 6.48 & 0.82 & 4.58 & 0.52 & 3.14 & 1.38 & 7.83 & 2.77 & 1.87 & 0.34 & 7.00 & 0.97 \\
\hline $\mathrm{Ba}$ & 787 & 89.2 & 626 & 66.3 & 728 & 160 & 838 & 98.2 & 697 & 52.5 & 785 & 93.7 \\
\hline La & 22.8 & 2.93 & 22.2 & 3.37 & 23.7 & 7.08 & 25.9 & 3.86 & 21.4 & 1.61 & 21.9 & 3.58 \\
\hline $\mathrm{Ce}$ & 50.1 & 4.34 & 51.3 & 4.61 & 52.9 & 6.26 & 56.6 & 8.14 & 48.7 & 3.22 & 51.5 & 4.51 \\
\hline $\operatorname{Pr}$ & 5.30 & 0.90 & 5.78 & 0.79 & 6.73 & 1.83 & 6.00 & 1.12 & 6.30 & 1.23 & 5.44 & 0.97 \\
\hline Nd & 22.0 & 4.07 & 24.5 & 3.56 & 30.0 & 6.88 & 22.9 & 1.80 & 31.9 & 5.52 & 20.8 & 3.97 \\
\hline $\mathrm{Sm}$ & 4.65 & 1.93 & 5.46 & 1.47 & 7.12 & 1.85 & 5.09 & 2.02 & 6.47 & 1.37 & 4.50 & 1.60 \\
\hline Eu & 0.40 & 0.43 & 1.12 & 0.38 & 1.59 & 1.01 & 0.62 & 0.43 & 1.17 & 0.51 & 0.42 & 0.33 \\
\hline Gd & 3.98 & 1.46 & 5.19 & 1.90 & 8.16 & 3.94 & 4.13 & 1.18 & 6.20 & 1.37 & 4.49 & 1.08 \\
\hline $\mathbf{T b}$ & 0.61 & 0.30 & 0.91 & 0.26 & 1.32 & 0.34 & 0.75 & 0.19 & 1.11 & 0.27 & 0.67 & 0.21 \\
\hline Dy & 4.89 & 2.14 & 6.28 & 1.64 & 9.57 & 4.79 & 5.41 & 2.20 & 8.97 & 1.95 & 4.78 & 1.43 \\
\hline Ho & 0.98 & 0.31 & 1.20 & 0.46 & 2.12 & 0.93 & 1.02 & 0.26 & 1.81 & 0.42 & 0.98 & 0.47 \\
\hline $\mathrm{Er}$ & 2.63 & 1.07 & 3.48 & 0.87 & 6.43 & 2.84 & 3.44 & 1.04 & 5.62 & 1.08 & 3.02 & 1.08 \\
\hline Tm & 0.43 & 0.44 & 0.54 & 0.18 & 0.93 & 0.34 & 0.51 & 0.20 & 0.86 & 0.18 & 0.40 & 0.22 \\
\hline $\mathbf{Y b}$ & 3.19 & 0.62 & 3.94 & 1.14 & 6.41 & 1.58 & 3.70 & 0.60 & 5.65 & 1.39 & 3.09 & 1.13 \\
\hline Lu & 0.35 & 0.29 & 0.50 & 0.17 & 0.89 & 0.22 & 0.56 & 0.28 & 0.91 & 0.32 & 0.43 & 0.31 \\
\hline Hf & 3.47 & 1.03 & 5.70 & 1.58 & 7.83 & 1.12 & 3.94 & 0.71 & 8.80 & 1.99 & 3.14 & 1.09 \\
\hline Ta & 0.53 & 0.39 & 0.53 & 0.22 & 0.73 & 0.29 & 0.58 & 0.24 & 0.79 & 0.35 & 0.69 & 0.30 \\
\hline W & 1.76 & 2.22 & 1.13 & 0.70 & 1.00 & 1.19 & 1.59 & 0.66 & 0.74 & 0.44 & 1.78 & 1.02 \\
\hline $\mathrm{Pb}$ & 21.4 & 3.95 & 19.6 & 3.84 & 16.3 & 3.67 & 21.2 & 4.56 & 13.3 & 1.66 & 21.0 & 3.03 \\
\hline Th & 10.8 & 1.30 & 7.88 & 1.36 & 7.53 & 1.67 & 12.8 & 0.92 & 6.19 & 1.16 & 11.0 & 1.74 \\
\hline $\mathbf{U}$ & 2.50 & 0.99 & 2.26 & 0.39 & 1.72 & 0.36 & 2.96 & 0.85 & 1.67 & 0.27 & 2.95 & 0.38 \\
\hline $\mathrm{Rb} / \mathrm{Sr}$ & 1.39 & 0.26 & 0.62 & 0.05 & 0.68 & 0.10 & 1.79 & 0.31 & 0.75 & 0.43 & 3.11 & 0.39 \\
\hline $\mathrm{Sr} / \mathrm{Y}$ & 3.41 & 0.71 & 4.34 & 0.39 & 2.00 & 0.45 & 2.39 & 0.28 & 1.57 & 0.80 & 1.68 & 0.18 \\
\hline $\mathrm{Zr} / \mathrm{Th}$ & 12.0 & 2.55 & 29.0 & 2.77 & 45.2 & 11.1 & 10.2 & 2.50 & 60.2 & 14.6 & 8.84 & 1.65 \\
\hline $\mathbf{E u} / \mathbf{E u} *$ & 0.31 & 0.37 & 0.66 & 0.31 & 0.64 & 0.35 & 0.42 & 0.30 & 0.57 & 0.30 & 0.28 & 0.21 \\
\hline $\mathrm{Zr} / \mathrm{Y}$ & 5.17 & 0.87 & 7.05 & 0.39 & 6.30 & 0.64 & 4.19 & 0.89 & 7.06 & 0.85 & 3.70 & 0.54 \\
\hline $\mathrm{Ba} / \mathrm{Sr}$ & 9.32 & 2.05 & 4.47 & 0.29 & 6.85 & 1.01 & 11.3 & 1.87 & 9.04 & 5.00 & 17.8 & 1.61 \\
\hline $\mathrm{Nb} / \mathrm{Pb}$ & 0.36 & 0.10 & 0.46 & 0.09 & 0.65 & 0.22 & 0.37 & 0.11 & 0.89 & 0.25 & 0.38 & 0.09 \\
\hline $\mathrm{La} / \mathrm{Yb}$ & 7.15 & 1.61 & 5.71 & 1.35 & 3.74 & 1.48 & 7.03 & 1.69 & 3.83 & 0.90 & 7.30 & 2.51 \\
\hline $\mathrm{Dy} / \mathrm{Yb}$ & 1.49 & 0.66 & 1.63 & 0.66 & 1.52 & 0.94 & 1.47 & 0.62 & 1.60 & 0.40 & 1.58 & 0.58 \\
\hline $\mathrm{Ba} / \mathrm{Th}$ & 73.3 & 13.8 & 79.8 & 12.1 & 96.7 & 6.89 & 65.3 & 6.11 & 113 & 20.4 & 71.4 & 11.3 \\
\hline
\end{tabular}

Table A3: continued. 


\begin{tabular}{|c|c|c|c|c|c|c|c|c|c|c|c|c|}
\hline \multirow{2}{*}{$\begin{array}{l}\text { Sample number }{ }^{a} \\
\text { Sample correlative }^{b}\end{array}$} & \multicolumn{2}{|l|}{ M-28 (1) } & \multicolumn{2}{|c|}{ M-28 (2) } & \multicolumn{2}{|l|}{ M-29 } & \multicolumn{2}{|l|}{ M-30 } & \multicolumn{2}{|l|}{ M-31 } & \multicolumn{2}{|l|}{ M-32 } \\
\hline & & & & & & & & & & & AT- 25 & \\
\hline Sample details ${ }^{c}$ & $1124 \mathrm{C}-1$ & $1 \mathrm{H}-2$ & $1124 C-$ & IH-2 & $1124 \mathrm{C}$ & IH-3 & $1124 \mathrm{C}$ & $\mathrm{H}-4$ & $1124 \mathrm{C}$ & H-6 & $1124 \mathrm{C}$ & $1 \mathrm{H}-7$ \\
\hline $\begin{array}{l}\text { mbsf }^{e} \\
\text { Age (Ma) }\end{array}$ & $\begin{array}{l}106.03 \mathrm{~m} \\
4.520\end{array}$ & & $\begin{array}{l}106.03 \\
4.520\end{array}$ & & $\begin{array}{l}106.67 \\
4.560\end{array}$ & & $\begin{array}{l}107.79 \\
4.650\end{array}$ & & $\begin{array}{l}111.64 \\
4.950\end{array}$ & & $\begin{array}{l}112.53 \\
5.085\end{array}$ & \\
\hline$n^{f}$ & 8 & & 3 & & 9 & & 12 & & 15 & & 16 & \\
\hline LA-ICP-MS & Mean $^{\mathrm{g}}$ & $2 s d^{h}$ & & & & & & & & & & \\
\hline $\mathrm{Li}(\mathrm{ppm})^{\mathrm{i}}$ & 28.5 & 11.2 & 30.2 & 3.11 & 32.6 & 7.44 & 30.9 & 10.6 & 24.1 & 2.69 & 32.0 & 6.93 \\
\hline B & 24.6 & 8.05 & 24.3 & 0.89 & 26.4 & 5.66 & 19.0 & 4.54 & 11.5 & 3.98 & 21.9 & 5.17 \\
\hline $\mathrm{Mg}$ & 726 & 254 & 2476 & 1610 & 1190 & 388 & 1080 & 109 & 4540 & 1540 & 1330 & 71.1 \\
\hline $\mathrm{Si}$ & 77.8 & 0.65 & 74.3 & 0.22 & 78.0 & 0.52 & 78.0 & 0.71 & 72.0 & 1.25 & 74.0 & 0.68 \\
\hline $\mathrm{Ca}$ & 0.72 & 0.21 & 1.40 & 0.57 & 0.82 & 0.23 & 0.91 & 0.09 & 2.14 & 0.49 & 1.39 & 0.15 \\
\hline Mn & 430 & 47.6 & 653 & 64.9 & 375 & 57.3 & 438 & 28.1 & 1170 & 183 & 971 & 67.4 \\
\hline $\mathrm{Ni}$ & 0.59 & 3.89 & 2.15 & 4.73 & 0.26 & 2.63 & 0.02 & 2.77 & 0.06 & 3.40 & 0.02 & 4.03 \\
\hline $\mathrm{Cu}$ & 7.11 & 13.4 & 9.06 & 13.8 & 6.33 & 4.10 & 5.72 & 7.71 & 4.46 & 8.51 & 19.9 & 47.2 \\
\hline $\mathrm{Zn}$ & 44.2 & 12.3 & 47.3 & 22.6 & 34.1 & 11.4 & 43.1 & 10.7 & 74.5 & 32.7 & 104 & 18.5 \\
\hline $\mathbf{R b}$ & 116 & 8.26 & 94.3 & 1.18 & 108 & 13.3 & 103 & 8.06 & 60.1 & 7.33 & 91.1 & 7.50 \\
\hline $\mathrm{Sr}$ & 39.4 & 11.7 & 100 & 5.68 & 51.9 & 12.6 & 61.6 & 8.65 & 140 & 40.4 & 93.3 & 5.80 \\
\hline $\mathbf{Y}$ & 34.8 & 4.58 & 36.4 & 5.23 & 19.7 & 6.86 & 25.7 & 2.91 & 56.2 & 9.30 & 62.3 & 5.08 \\
\hline $\mathrm{Zr}$ & 135 & 26.5 & 298 & 10.7 & 150 & 35.1 & 145 & 16.3 & 286 & 37.5 & 344 & 26.6 \\
\hline $\mathrm{Nb}$ & 10.4 & 1.78 & 10.8 & 2.22 & 7.59 & 1.64 & 8.59 & 1.14 & 11.5 & 2.16 & 13.8 & 1.80 \\
\hline Cs & 4.20 & 0.89 & 3.44 & 0.29 & 3.57 & 0.57 & 3.56 & 0.57 & 2.25 & 0.67 & 3.15 & 0.44 \\
\hline $\mathrm{Ba}$ & 966 & 139 & 924 & 126 & 824 & 157 & 863 & 67.9 & 686 & 108 & 685 & 54.6 \\
\hline Dy & 5.36 & 1.69 & 6.14 & 2.23 & 2.61 & 1.54 & 3.68 & 1.56 & 9.71 & 1.89 & 10.8 & 2.22 \\
\hline Ho & 1.01 & 0.49 & 1.05 & 0.61 & 0.55 & 0.27 & 0.93 & 0.31 & 2.01 & 0.42 & 2.34 & 0.38 \\
\hline Er & 3.99 & 2.93 & 4.11 & 1.41 & 1.86 & 0.57 & 2.48 & 0.79 & 6.03 & 1.09 & 6.79 & 0.92 \\
\hline $\mathrm{Tm}$ & 0.68 & 0.45 & 0.53 & 0.12 & 0.22 & 0.20 & 0.39 & 0.43 & 0.93 & 0.28 & 1.07 & 0.41 \\
\hline $\mathbf{Y b}$ & 3.88 & 2.07 & 4.04 & 2.41 & 2.36 & 0.91 & 3.16 & 1.83 & 6.65 & 1.28 & 7.44 & 2.00 \\
\hline Lu & 0.61 & 0.30 & 0.55 & 0.28 & 0.36 & 0.33 & 0.55 & 0.30 & 0.88 & 0.27 & 1.08 & 0.32 \\
\hline Hf & 4.17 & 1.39 & 6.01 & 2.70 & 3.88 & 2.07 & 4.39 & 1.93 & 8.36 & 1.84 & 9.27 & 1.47 \\
\hline Ta & 0.71 & 0.92 & 0.77 & 0.77 & 0.78 & 0.37 & 0.69 & 0.48 & 0.66 & 0.35 & 0.81 & 0.22 \\
\hline W & 2.17 & 1.47 & 0.91 & 1.10 & 1.22 & 0.51 & 0.92 & 1.10 & 0.58 & 0.77 & 1.56 & 2.78 \\
\hline $\mathrm{Pb}$ & 17.4 & 1.79 & 17.0 & 2.55 & 13.6 & 1.78 & 16.6 & 2.37 & 16.2 & 3.35 & 19.6 & 2.90 \\
\hline Th & 11.0 & 2.06 & 9.19 & 1.83 & 11.2 & 2.95 & 11.2 & 1.69 & 7.18 & 1.35 & 8.89 & 0.83 \\
\hline $\mathbf{U}$ & 2.90 & 0.95 & 2.37 & 0.65 & 2.74 & 0.36 & 2.72 & 0.57 & 1.70 & 0.30 & 2.35 & 0.48 \\
\hline $\mathrm{Rb} / \mathrm{Sr}$ & 3.01 & 1.02 & 0.94 & 0.06 & 2.10 & 0.43 & 1.68 & 0.23 & 0.44 & 0.17 & 0.98 & 0.12 \\
\hline $\mathrm{Sr} / \mathrm{Y}$ & 1.13 & 0.31 & 2.77 & 0.31 & 2.66 & 0.49 & 2.39 & 0.13 & 2.51 & 0.77 & 1.50 & 0.16 \\
\hline $\mathrm{Zr} / \mathrm{Th}$ & 12.4 & 3.25 & 32.7 & 6.79 & 13.5 & 2.40 & 13.0 & 1.66 & 40.0 & 6.82 & 38.8 & 4.32 \\
\hline $\mathrm{Eu} / \mathbf{E u} \mathbf{u}^{*}$ & 0.36 & 0.30 & 0.84 & 0.92 & 0.52 & 0.35 & 0.49 & 0.70 & 0.65 & 0.27 & 0.53 & 0.12 \\
\hline $\mathrm{Zr} / \mathrm{Y}$ & 3.89 & 0.64 & 8.21 & 0.96 & 7.75 & 1.99 & 5.64 & 0.37 & 5.10 & 0.53 & 5.52 & 0.39 \\
\hline $\mathrm{Ba} / \mathrm{Sr}$ & 24.9 & 6.91 & 9.22 & 1.68 & 16.0 & 1.75 & 14.1 & 1.60 & 5.01 & 1.84 & 7.34 & 0.75 \\
\hline $\mathrm{Nb} / \mathrm{Pb}$ & 0.60 & 0.11 & 0.63 & 0.11 & 0.56 & 0.11 & 0.52 & 0.08 & 0.72 & 0.21 & 0.70 & 0.13 \\
\hline $\mathrm{La} / \mathrm{Yb}$ & 6.40 & 2.81 & 6.16 & 2.29 & 8.02 & 4.16 & 7.92 & 7.22 & 3.66 & 0.80 & 3.99 & 1.51 \\
\hline $\mathrm{Dy} / \mathrm{Yb}$ & 1.48 & 1.00 & 1.55 & 0.32 & 1.11 & 0.47 & 1.39 & 1.93 & 1.47 & 0.33 & 1.46 & 0.29 \\
\hline $\mathrm{Ba} / \mathrm{Th}$ & 88.7 & 22.8 & 102 & 32.6 & 73.9 & 11.1 & 77.4 & 10.3 & 96.0 & 16.1 & 77.2 & 8.38 \\
\hline
\end{tabular}

Table A3: continued. 


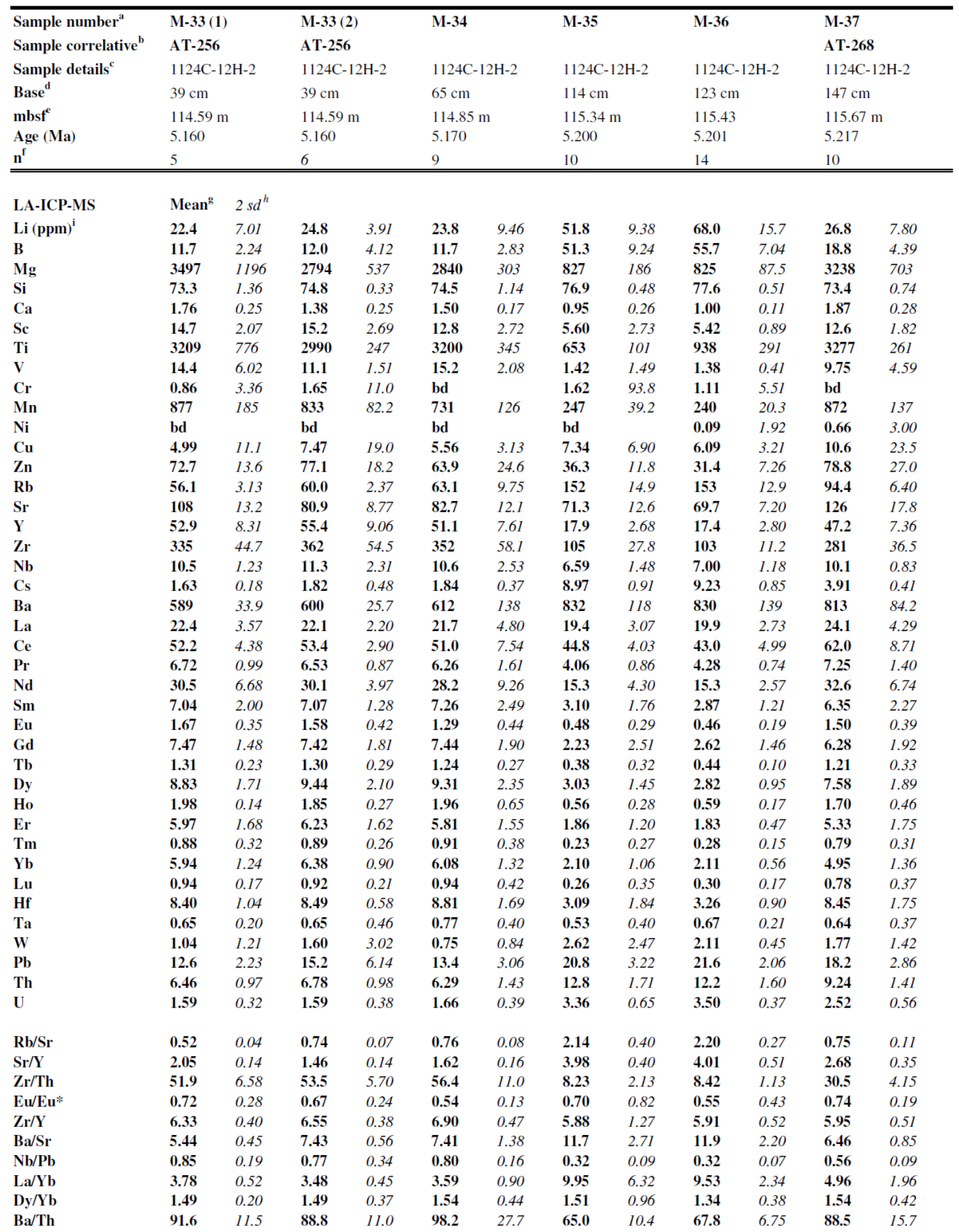

Table A3: continued. 


\begin{tabular}{|c|c|c|c|c|c|c|c|c|c|c|c|c|}
\hline Sample number ${ }^{\mathrm{a}}$ & M-38 & & M-39 & & M-40 & & M-41 & & M-42 & & M-43 & \\
\hline Sample correlative & & & & & & & & & & & & \\
\hline Sample details ${ }^{\mathrm{c}}$ & $1124 \mathrm{C}-1$ & $2 \mathrm{H}-3$ & $1124 C-$ & $2 \mathrm{H}-3$ & $1124 \mathrm{C}$ & $2 \mathrm{H}-4$ & $1124 \mathrm{C}$ & $2 \mathrm{H}-5$ & $1124 \mathrm{C}$ & $2 \mathrm{H}-5$ & $1124 C$ & $2 \mathrm{H}-5$ \\
\hline $\begin{array}{l}\text { mbsf }^{e} \\
\text { Age (Ma) }\end{array}$ & $\begin{array}{l}116.39 n \\
5.250\end{array}$ & & $\begin{array}{l}116.42 \\
5.255\end{array}$ & & $\begin{array}{l}118.54 \\
5.378\end{array}$ & & $\begin{array}{l}118.79 \\
5.387\end{array}$ & & $\begin{array}{l}118.80 \\
5.590\end{array}$ & & $\begin{array}{l}119.7 \\
5.440\end{array}$ & \\
\hline$n^{f}$ & 3 & & 2 & & 16 & & 17 & & 10 & & 13 & \\
\hline LA-ICP-MS & Mean $^{\mathrm{g}}$ & $2 s d^{h}$ & & & & & & & & & & \\
\hline $\mathbf{L i}(\mathbf{p p m})^{\mathrm{i}}$ & 34.5 & 1.25 & 23.1 & 0.55 & 41.9 & 11.7 & 26.3 & 6.22 & 28.7 & 5.74 & 28.0 & 7.16 \\
\hline B & 14.9 & 2.94 & 8.89 & 2.82 & 13.3 & 15.5 & 10.8 & 5.78 & 12.9 & 11.6 & 15.5 & 7.57 \\
\hline $\mathrm{Mg}$ & 1200 & 142 & 3190 & 1080 & 1410 & 169 & 2940 & 1080 & 3160 & 2350 & 1040 & 130 \\
\hline $\mathrm{Si}$ & 77.4 & 0.37 & 74.5 & 0.65 & 76.7 & 0.54 & 74.8 & 1.66 & 75.0 & 2.29 & 78.1 & 1.30 \\
\hline $\mathrm{Ca}$ & 1.23 & 0.42 & 1.52 & 0.34 & 0.93 & 0.72 & 1.68 & 0.45 & 1.65 & 0.81 & 0.78 & 0.24 \\
\hline Mn & 1120 & 145 & 729 & 169 & 312 & 69.6 & 769 & 134 & 714 & 194 & 390 & 28.9 \\
\hline $\mathrm{Ni}$ & 0.99 & 4.19 & 0.23 & 1.48 & bd & & bd & & bd & & bd & \\
\hline $\mathrm{Cu}$ & 4.28 & 4.46 & 3.35 & 2.52 & 4.86 & 361 & 2.89 & 4.93 & 9.68 & 45.2 & 3.01 & 7.31 \\
\hline $\mathrm{Zn}$ & 47.7 & 8.18 & 47.4 & 39.7 & 28.6 & 13.6 & 66.7 & 21.0 & 66.6 & 30.3 & 37.7 & 12.6 \\
\hline Rb & 89.0 & 8.36 & 58.0 & 2.16 & 112 & 17.9 & 80.5 & 11.4 & 81.6 & 20.0 & 97.6 & 10.0 \\
\hline $\mathrm{Sr}$ & 101 & 6.81 & 104 & 30.6 & 63.4 & 13.2 & 135 & 38.8 & 138 & 61.8 & 46.7 & 6.95 \\
\hline $\mathbf{Y}$ & 27.0 & 2.15 & 47.6 & 12.8 & 15.5 & 3.50 & 37.5 & 3.52 & 41.2 & 10.4 & 22.2 & 3.19 \\
\hline $\mathrm{Zr}$ & 152 & 19.6 & 340 & 43.4 & 123 & 24.3 & 227 & 36.4 & 240 & 45.1 & 98.4 & 11.0 \\
\hline $\mathrm{Nb}$ & 7.67 & 1.85 & 9.74 & 1.12 & 5.71 & 1.38 & 6.94 & 1.15 & 7.93 & 2.00 & 6.83 & 1.70 \\
\hline Cs & 3.73 & 1.07 & 1.90 & 0.06 & 4.15 & 1.83 & 2.86 & 0.54 & 2.94 & 1.08 & 2.86 & 0.66 \\
\hline $\mathrm{Ba}$ & 597 & 27.7 & 564 & 86.4 & 558 & 235 & 644 & 88.9 & 543 & 60.0 & 622 & 84.7 \\
\hline Dy & 4.83 & 1.29 & 7.85 & 0.45 & 2.42 & 2.30 & 6.37 & 2.31 & 7.68 & 2.46 & 3.82 & 1.34 \\
\hline Ho & 0.85 & 0.46 & 1.65 & 0.29 & 0.43 & 0.66 & 1.42 & 0.52 & 1.35 & 0.34 & 0.81 & 0.37 \\
\hline $\mathrm{Er}$ & 3.11 & 0.75 & 5.12 & 0.08 & 2.03 & 1.64 & 4.50 & 1.63 & 4.67 & 1.44 & 2.51 & 1.19 \\
\hline $\mathrm{Tm}$ & 0.39 & 0.03 & 0.84 & 0.23 & 0.07 & 0.39 & 0.66 & 0.44 & 0.67 & 0.33 & 0.30 & 0.33 \\
\hline $\mathbf{Y b}$ & 3.98 & 2.11 & 6.46 & 3.22 & 2.12 & 2.25 & 4.88 & 1.92 & 4.67 & 1.82 & 3.20 & 1.90 \\
\hline Lu & 0.40 & 0.05 & 0.80 & 0.36 & 0.23 & 0.37 & 0.65 & 0.35 & 0.69 & 0.24 & 0.41 & 0.34 \\
\hline Hf & 3.55 & 1.49 & 7.70 & 0.75 & 2.42 & 2.91 & 6.16 & 1.07 & 6.56 & 1.61 & 3.20 & 1.51 \\
\hline Ta & 0.46 & 0.10 & 0.63 & 0.33 & 0.53 & 0.60 & 0.45 & 0.45 & 0.54 & 0.46 & 0.53 & 0.28 \\
\hline W & 1.04 & 1.07 & 0.64 & 0.51 & 0.72 & 2.11 & 1.04 & 1.60 & 0.72 & 1.21 & 1.06 & 1.51 \\
\hline $\mathrm{Pb}$ & 14.8 & 2.15 & 11.7 & 0.58 & 12.2 & 7.02 & 17.7 & 4.69 & 18.1 & 3.95 & 11.0 & 2.26 \\
\hline Th & 8.60 & 0.52 & 7.00 & 1.76 & 8.53 & 4.24 & 8.20 & 1.67 & 9.19 & 1.14 & 9.25 & 1.47 \\
\hline $\mathbf{U}$ & 2.16 & 0.53 & 1.55 & 0.36 & 2.27 & 1.28 & 2.00 & 0.63 & 1.97 & 0.67 & 2.37 & 0.31 \\
\hline $\mathrm{Rb} / \mathrm{Sr}$ & 0.88 & 0.06 & 0.56 & 0.15 & 1.78 & 0.23 & 0.61 & 0.23 & 0.61 & 0.29 & 2.10 & 0.38 \\
\hline $\mathrm{Sr} / \mathrm{Y}$ & 3.73 & 0.28 & 2.18 & 0.06 & 4.13 & 1.06 & 3.61 & 0.98 & 3.34 & 0.98 & 2.10 & 0.23 \\
\hline $\mathrm{Zr} / \mathrm{Th}$ & 17.7 & 2.86 & 48.9 & 6.12 & 15.1 & 6.06 & 27.9 & 6.29 & 26.3 & 6.03 & 10.7 & 1.70 \\
\hline $\mathbf{E u} / \mathbf{E u}^{*}$ & 0.64 & 0.52 & 0.67 & 0.01 & 0.41 & 0.60 & 0.76 & 0.41 & 0.76 & 0.27 & 0.51 & 0.56 \\
\hline $\mathrm{Zr} / \mathrm{Y}$ & 5.62 & 0.30 & 7.18 & 1.01 & 7.97 & 1.72 & 6.05 & 0.73 & 5.86 & 0.62 & 4.44 & 0.45 \\
\hline $\mathrm{Ba} / \mathrm{Sr}$ & 5.93 & 0.55 & 5.46 & 0.78 & 8.74 & 2.68 & 4.86 & 1.59 & 4.06 & 1.51 & 13.4 & 2.47 \\
\hline $\mathrm{Nb} / \mathrm{Pb}$ & 0.52 & 0.15 & 0.83 & 0.14 & 0.51 & 0.37 & 0.40 & 0.11 & 0.44 & 0.07 & 0.63 & 0.20 \\
\hline $\mathrm{La} / \mathrm{Yb}$ & 4.71 & 2.81 & 3.29 & 1.17 & 8.60 & 10.4 & 4.48 & 1.90 & 4.56 & 1.29 & 6.45 & 4.52 \\
\hline Dy/Yb & 1.31 & 1.06 & 1.26 & 0.70 & 1.43 & 2.18 & 1.36 & 0.79 & 1.68 & 0.63 & 1.32 & 1.01 \\
\hline $\mathrm{Ba} / \mathrm{Th}$ & 69.4 & 5.23 & 80.9 & 8.06 & 66.4 & 15.1 & 79.2 & 15.0 & 59.3 & 10.3 & 67.7 & 14.4 \\
\hline
\end{tabular}

Table A3: continued. 


\begin{tabular}{|c|c|c|c|c|c|c|c|c|c|c|c|c|}
\hline \multirow{2}{*}{$\begin{array}{l}\text { Sample number }{ }^{a} \\
\text { Sample correlative }^{b}\end{array}$} & \multicolumn{2}{|l|}{ M-44 } & \multicolumn{2}{|l|}{ M-45 } & \multicolumn{2}{|c|}{ M-46 (1) } & \multicolumn{2}{|c|}{ M-46 (2) } & \multicolumn{2}{|c|}{ M-46 (3) } & \multicolumn{2}{|c|}{ M-47 (1) } \\
\hline & & & & & & & & & & & AT- 25 & \\
\hline Sample details ${ }^{\mathrm{c}}$ & $1124 \mathrm{C}-1$ & $2 \mathrm{H}-6$ & $1124 \mathrm{C}$ & $\mathrm{H}-4$ & $1124 C-$ & $\mathrm{H}-5$ & $1124 \mathrm{C}$ & $3 \mathrm{H}-5$ & $1124 \mathrm{C}-1$ & $\mathrm{H}-5$ & $1124 \mathrm{C}-$ & $3 \mathrm{H}-6$ \\
\hline Base $^{d}$ & $124.5 \mathrm{~cm}$ & & $77 \mathrm{~cm}$ & & $72 \mathrm{~cm}$ & & $72 \mathrm{~cm}$ & & $72 \mathrm{~cm}$ & & $27 \mathrm{~cm}$ & \\
\hline mbsf $^{e}$ & $121.45 \mathrm{~m}$ & & 127.47 & & 128.92 & & 128.92 & & $128.92 n$ & & 129.97 & \\
\hline$n^{f}$ & 9 & & 10 & & 2 & & 4 & & 5 & & 11 & \\
\hline LA-ICP-MS & Mean $^{\mathrm{g}}$ & $2 s d^{h}$ & & & & & & & & & & \\
\hline $\mathrm{Li}(\mathrm{ppm})^{\mathrm{i}}$ & 21.6 & 12.5 & 28.7 & 9.72 & 20.0 & 2.70 & 18.6 & 29.7 & 12.8 & 7.68 & 29.3 & 8.28 \\
\hline B & 13.7 & 7.70 & 13.9 & 11.6 & 4.05 & 1.21 & 9.20 & 7.29 & 4.37 & 4.96 & 14.9 & 4.54 \\
\hline $\mathrm{Mg}$ & 1750 & 545 & 3440 & 2450 & 8899 & 211 & 2574 & 1624 & 22802 & 5236 & 2135 & 318 \\
\hline $\mathrm{Si}$ & 75.4 & 0.68 & 74.6 & 0.85 & 68.7 & 1.12 & 75.7 & 0.77 & 58.2 & 3.57 & 75.7 & 1.27 \\
\hline $\mathrm{Ca}$ & 1.31 & 0.18 & 1.63 & 0.30 & 3.43 & 0.47 & 1.59 & 0.73 & 7.40 & 2.86 & 1.41 & 0.21 \\
\hline $\mathrm{Sc}$ & 14.7 & 4.71 & 18.0 & 5.77 & 18.2 & 3.88 & 13.7 & 5.83 & 30.8 & 4.27 & 7.49 & 1.94 \\
\hline $\mathrm{Ti}$ & 1660 & 240 & 2440 & 298 & 6791 & 513 & 2527 & 1448 & 10624 & 2120 & 1548 & 152 \\
\hline V & 1.00 & 1.37 & 7.23 & 15.8 & 30.6 & 2.99 & 2.05 & 4.53 & 253 & 102 & 4.42 & 1.42 \\
\hline $\mathrm{Cr}$ & bd & & bd & & 16.2 & 30.8 & 21.2 & 79.5 & 12.2 & 15.6 & 2.83 & 71.8 \\
\hline Mn & 991 & 98.4 & 635 & 94.0 & 2060 & 131 & 1330 & 285 & 2209 & 479 & 582 & 50.1 \\
\hline $\mathrm{Ni}$ & 0.80 & 6.29 & 1.95 & 11.4 & bd & & bd & & 1.92 & 3.26 & bd & \\
\hline $\mathrm{Cu}$ & 4.51 & 11.0 & 3.81 & 13.4 & 13.4 & 32.6 & 4.24 & 12.4 & 28.0 & 21.7 & 3.23 & 7.19 \\
\hline $\mathrm{Zn}$ & 74.2 & 43.2 & 62.9 & 27.6 & 86.6 & 55.0 & 75.4 & 19.2 & 101 & 56.5 & 50.1 & 17.3 \\
\hline Rb & 90.2 & 10.2 & 68.7 & 11.0 & 47.9 & 3.09 & 78.5 & 11.4 & 23.7 & 14.6 & 85.8 & 10.0 \\
\hline $\mathrm{Sr}$ & 106 & 7.35 & 145 & 22.9 & 209 & 10.3 & 103 & 77.2 & 287 & 121 & 125 & 18.0 \\
\hline $\mathbf{Y}$ & 38.1 & 7.52 & 34.0 & 5.84 & 64.2 & 0.24 & 60.8 & 31.7 & 40.5 & 24.1 & 29.6 & 6.14 \\
\hline $\mathrm{Zr}$ & 206 & 34.6 & 198 & 41.3 & 319 & 13.4 & 407 & 257 & 175 & 118 & 213 & 39.8 \\
\hline $\mathrm{Nb}$ & 8.38 & 1.31 & 5.76 & 2.01 & 11.0 & 1.84 & 13.1 & 5.36 & 5.81 & 3.04 & 7.95 & 1.48 \\
\hline Cs & 3.79 & 0.60 & 2.83 & 0.94 & 2.45 & 1.08 & 4.59 & 0.26 & 1.13 & 0.76 & 4.40 & 0.61 \\
\hline $\mathrm{Ba}$ & 596 & 38.2 & 480 & 67.7 & 370 & 17.1 & 531 & 31.8 & 230 & 89.6 & 630 & 66.4 \\
\hline La & 20.2 & 3.67 & 19.8 & 3.86 & 20.1 & 1.81 & 25.5 & 4.34 & 12.0 & 7.39 & 22.8 & 3.01 \\
\hline $\mathrm{Ce}$ & 47.7 & 3.03 & 42.3 & 6.05 & 49.5 & 3.28 & 63.7 & 17.3 & 29.5 & 13.6 & 46.5 & 3.59 \\
\hline $\mathrm{Pr}$ & 5.36 & 1.08 & 5.07 & 1.04 & 6.56 & 0.75 & 7.28 & 2.23 & 4.24 & 2.46 & 5.16 & 0.97 \\
\hline Nd & 25.5 & 4.92 & 20.0 & 4.05 & 28.7 & 4.00 & 32.2 & 12.5 & 18.8 & 7.93 & 22.9 & 2.85 \\
\hline $\mathrm{Sm}$ & 6.16 & 3.06 & 6.52 & 4.97 & 8.09 & 1.07 & 8.20 & 2.05 & 4.98 & 3.26 & 4.00 & 1.74 \\
\hline Eu & 1.35 & 0.43 & 1.00 & 0.68 & 2.18 & 0.08 & 1.70 & 1.76 & 1.47 & 0.62 & 1.02 & 0.49 \\
\hline Gd & 5.56 & 1.50 & 5.44 & 3.05 & 8.53 & 0.78 & 9.16 & 4.28 & 6.14 & 2.98 & 3.64 & 2.07 \\
\hline Tb & 0.81 & 0.40 & 0.89 & 0.38 & 1.58 & 0.35 & 1.25 & 1.04 & 0.85 & 0.33 & 0.65 & 0.27 \\
\hline Dy & 6.34 & 1.39 & 5.77 & 2.69 & 8.82 & 0.97 & 8.17 & 3.99 & 6.40 & 3.37 & 4.80 & 2.03 \\
\hline Ho & 1.27 & 0.42 & 1.43 & 0.90 & 2.19 & 0.03 & 1.90 & 1.06 & 1.18 & 1.06 & 1.13 & 0.25 \\
\hline $\mathrm{Er}$ & 4.40 & 0.89 & 3.83 & 1.90 & 6.17 & 1.95 & 6.14 & 4.44 & 3.85 & 1.36 & 3.33 & 1.12 \\
\hline $\mathrm{Tm}$ & 0.58 & 0.25 & 0.52 & 0.47 & 0.79 & 0.18 & 0.71 & 0.57 & 0.69 & 0.35 & 0.43 & 0.20 \\
\hline Yb & 4.28 & 1.45 & 2.91 & 2.04 & 6.73 & 0.66 & 7.10 & 2.52 & 4.08 & 0.91 & 3.39 & 0.75 \\
\hline Lu & 0.61 & 0.28 & 0.46 & 0.43 & 0.75 & 0.40 & 0.89 & 0.34 & 0.45 & 0.45 & 0.57 & 0.17 \\
\hline $\mathrm{Hf}$ & 5.53 & 1.62 & 5.60 & 1.23 & 7.29 & 1.14 & 9.59 & 8.16 & 3.87 & 3.93 & 5.54 & 1.55 \\
\hline Ta & 0.76 & 0.56 & 0.61 & 0.60 & 0.31 & 0.16 & 1.04 & 0.53 & 0.33 & 0.27 & 0.63 & 0.36 \\
\hline W & 1.39 & 1.52 & 0.67 & 1.98 & 1.35 & 0.38 & 0.10 & 1.41 & 0.07 & 0.45 & 1.25 & 1.18 \\
\hline $\mathrm{Pb}$ & 17.0 & 3.08 & 16.4 & 7.17 & 9.68 & 2.99 & 14.3 & 4.25 & 5.95 & 1.98 & 16.1 & 1.73 \\
\hline Th & 8.54 & 2.03 & 8.58 & 1.48 & 5.45 & 1.00 & 8.85 & 2.70 & 2.79 & 2.68 & 9.47 & 2.00 \\
\hline $\mathbf{U}$ & 2.05 & 0.37 & 1.96 & 0.62 & 1.31 & 0.37 & 1.51 & 0.79 & 0.59 & 0.30 & 1.94 & 0.51 \\
\hline $\mathrm{Rb} / \mathrm{Sr}$ & 0.85 & 0.09 & 0.47 & 0.09 & 0.23 & 0.03 & 0.84 & 0.57 & 0.09 & 0.08 & 0.69 & 0.14 \\
\hline $\mathrm{Sr} / \mathrm{Y}$ & 2.79 & 0.42 & 4.30 & 0.94 & 3.26 & 0.17 & 1.93 & 2.77 & 8.02 & 8.70 & 4.26 & 0.70 \\
\hline $\mathrm{Zr} / \mathrm{Th}$ & 24.2 & 3.52 & 23.1 & 4.75 & 58.8 & 13.2 & 46.5 & 32.1 & 66.2 & 21.2 & 22.7 & 5.64 \\
\hline $\mathrm{Eu} / \mathbf{E u}^{*}$ & 0.73 & 0.32 & 0.55 & 0.37 & 0.80 & 0.04 & 0.62 & 0.68 & 0.84 & 0.34 & 0.85 & 0.46 \\
\hline $\mathrm{Zr} / \mathrm{Y}$ & 5.41 & 0.49 & 5.83 & 1.05 & 4.97 & 0.23 & 6.60 & 1.10 & 4.26 & 0.38 & 7.25 & 1.65 \\
\hline $\mathrm{Ba} / \mathrm{Sr}$ & 5.64 & 0.23 & 3.32 & 0.67 & 1.77 & 0.17 & 5.72 & 3.97 & 0.85 & 0.57 & 5.06 & 1.02 \\
\hline $\mathrm{Nb} / \mathrm{Pb}$ & 0.50 & 0.12 & 0.36 & 0.19 & 1.16 & 0.55 & 0.95 & 0.59 & 1.03 & 0.86 & 0.50 & 0.10 \\
\hline $\mathrm{La} / \mathrm{Yb}$ & 4.80 & 1.30 & 7.64 & 5.72 & 2.98 & 0.56 & 3.70 & 1.91 & 2.90 & 1.34 & 6.77 & 1.41 \\
\hline $\mathrm{Dy} / \mathrm{Yb}$ & 1.51 & 0.46 & 2.22 & 2.00 & 1.31 & 0.27 & 1.21 & 0.91 & 1.56 & 0.65 & 1.41 & 0.48 \\
\hline $\mathrm{Ba} / \mathrm{Th}$ & 70.5 & 14.0 & 56.2 & 9.96 & 68.0 & 9.28 & 60.8 & 14.7 & 92.7 & 57.7 & 67.1 & 13.3 \\
\hline
\end{tabular}

Table A3: continued. 


\begin{tabular}{|c|c|c|c|c|c|c|c|c|c|c|c|c|}
\hline Sample number ${ }^{a}$ & \multicolumn{2}{|l|}{$\mathrm{M}-47$ (2) } & \multicolumn{2}{|l|}{ M-48 } & \multicolumn{2}{|l|}{ M-49 } & \multicolumn{2}{|l|}{ M-50 } & \multicolumn{2}{|l|}{ M-51 } & \multicolumn{2}{|l|}{ M-52 } \\
\hline Sample correlative $^{b}$ & \multicolumn{4}{|l|}{ AT-253 } & \multicolumn{4}{|c|}{ AT-258 } & & & & \\
\hline Sample details ${ }^{\mathrm{c}}$ & \multicolumn{2}{|c|}{$1124 \mathrm{C}-13 \mathrm{H}-6$} & \multicolumn{2}{|c|}{$1124 \mathrm{C}-13 \mathrm{H}-6$} & \multicolumn{2}{|c|}{$1124 \mathrm{C}-13 \mathrm{H}-7$} & \multicolumn{2}{|c|}{$1124 \mathrm{C}-14 \mathrm{H}-1$} & \multicolumn{2}{|c|}{$1124 \mathrm{C}-14 \mathrm{H}-1$} & \multicolumn{2}{|c|}{$1124 \mathrm{C}-15 \mathrm{H}-2$} \\
\hline Base $^{\mathrm{d}}$ & $27 \mathrm{~cm}$ & & $101 \mathrm{~cm}$ & & $60 \mathrm{~cm}$ & & $113 \mathrm{~cm}$ & & $137 \mathrm{~cm}$ & & $122 \mathrm{cl}$ & \\
\hline mbsf $^{e}$ & $\begin{array}{l}129.97 \mathrm{~m} \\
6.066\end{array}$ & & $\begin{array}{l}130.71 \\
6.100\end{array}$ & & $\begin{array}{l}131.80 \\
6.154\end{array}$ & & $\begin{array}{l}132.83 \\
6.264\end{array}$ & & $\begin{array}{l}133.07 \\
6.279\end{array}$ & & $\begin{array}{l}143.9 \\
6.990\end{array}$ & \\
\hline$n^{f}$ & 4 & & 16 & & 17 & & 15 & & 13 & & 10 & \\
\hline LA-ICP-MS & Mean $^{g}$ & $2 s d^{h}$ & & & & & & & & & & \\
\hline $\mathrm{Li}(\mathrm{ppm})^{\mathrm{i}}$ & 22.8 & 12.5 & 25.1 & 6.84 & 30.7 & 26.2 & 47.6 & 21.4 & 32.5 & 12.7 & 46.5 & 32.3 \\
\hline B & 10.2 & 5.05 & 9.03 & 3.68 & 30.9 & 9.76 & 39.6 & 29.4 & 11.9 & 5.99 & 86.7 & 58.0 \\
\hline $\mathrm{Mg}$ & 1306 & 45.8 & 1430 & 206 & 859 & 333 & 736 & 104 & 1280 & 262 & 462 & 409 \\
\hline $\mathrm{Si}$ & 77.8 & 0.80 & 78.4 & 0.45 & 77.6 & 1.01 & 77.0 & 0.64 & 76.2 & 1.54 & 77.1 & 0.66 \\
\hline $\mathrm{Ca}$ & 0.90 & 0.06 & 0.93 & 0.20 & 0.65 & 0.27 & 0.98 & 0.55 & 1.15 & 0.19 & 0.95 & 0.94 \\
\hline $\mathrm{Sc}$ & 8.67 & 3.34 & 10.1 & 2.88 & 5.15 & 4.29 & 7.53 & 13.6 & 13.3 & 3.39 & 5.63 & 10.4 \\
\hline $\mathrm{Ti}$ & 1593 & 123 & 1410 & 297 & 866 & 139 & 1580 & 292 & 1500 & 337 & 531 & 485 \\
\hline V & 7.77 & 1.02 & 7.58 & 2.31 & 2.02 & 2.90 & 2.67 & 5.09 & 0.25 & 0.91 & bd & \\
\hline $\mathrm{Cr}$ & bd & & bd & & bd & & bd & & 3.13 & 19.7 & 13.6 & 82.5 \\
\hline Mn & 387 & 27.0 & 515 & 159 & 510 & 90.6 & 571 & 110 & 823 & 123 & 583 & 171 \\
\hline $\mathrm{Ni}$ & bd & & 0.06 & 7.23 & bd & & 11.9 & 59.8 & bd & & bd & \\
\hline $\mathrm{Cu}$ & 1.26 & 5.48 & 2.99 & 7.32 & 14.5 & 50.8 & 8.44 & 376 & 3.03 & 7.05 & bd & \\
\hline $\mathrm{Zn}$ & 43.0 & 15.6 & 33.1 & 9.94 & 21.0 & 17.3 & 70.2 & 64.3 & 78.5 & 28.7 & 22.5 & 22.2 \\
\hline $\mathbf{R b}$ & 111 & 1.75 & 107 & 10.4 & 157 & 16.2 & 305 & 42.5 & 98.9 & 5.77 & 162 & 27.8 \\
\hline $\mathrm{Sr}$ & 61.1 & 6.99 & 57.7 & 9.92 & 41.0 & 11.5 & 76.3 & 21.0 & 77.2 & 12.3 & 32.4 & 21.8 \\
\hline $\mathbf{Y}$ & 31.8 & 3.80 & 31.5 & 5.03 & 21.5 & 9.29 & 40.0 & 15.1 & 49.3 & 11.0 & 24.2 & 5.51 \\
\hline $\mathrm{Zr}$ & 176 & 10.4 & 180 & 72.3 & 84.9 & 22.5 & 189 & 51.9 & 302 & 64.4 & 56.8 & 35.3 \\
\hline $\mathrm{Nb}$ & 7.22 & 1.06 & 6.91 & 1.75 & 7.76 & 2.17 & 11.7 & 6.30 & 11.1 & 2.63 & 8.36 & 3.31 \\
\hline Cs & 3.27 & 0.71 & 3.19 & 0.66 & 5.32 & 1.18 & 19.9 & 8.04 & 4.97 & 0.45 & 9.16 & 2.32 \\
\hline $\mathrm{Ba}$ & 750 & 38.3 & 711 & 179 & 835 & 114 & 2711 & 441 & 565 & 91.6 & 830 & 130 \\
\hline $\mathrm{La}$ & 22.7 & 5.12 & 21.1 & 3.85 & 22.9 & 6.77 & 54.2 & 18.7 & 30.2 & 3.48 & 25.9 & 3.03 \\
\hline $\mathrm{Ce}$ & 47.5 & 4.52 & 46.4 & 4.37 & 43.2 & 8.26 & 128 & 28.8 & 62.8 & 4.87 & 52.7 & 7.59 \\
\hline $\mathrm{Pr}$ & 4.98 & 0.68 & 5.31 & 1.15 & 4.23 & 1.09 & 10.4 & 3.91 & 7.91 & 1.47 & 4.31 & 1.34 \\
\hline Nd & 20.8 & 1.18 & 23.4 & 4.96 & 16.1 & 7.96 & 39.0 & 21.4 & 33.9 & 3.54 & 15.6 & 6.82 \\
\hline $\mathrm{Sm}$ & 4.43 & 0.63 & 4.41 & 2.29 & 3.26 & 3.74 & 8.33 & 21.0 & 7.88 & 2.42 & 3.38 & 3.55 \\
\hline Eu & 0.79 & 0.76 & 0.67 & 0.36 & 0.28 & 0.77 & 0.67 & 2.83 & 1.44 & 0.64 & 0.15 & 0.64 \\
\hline Gd & 5.43 & 3.56 & 5.73 & 2.12 & 1.81 & 3.08 & 7.47 & 14.3 & 8.82 & 2.98 & 2.45 & 3.38 \\
\hline $\mathrm{Tb}$ & 0.50 & 0.11 & 0.80 & 0.46 & 0.32 & 0.31 & 1.57 & 2.64 & 1.27 & 0.30 & 0.25 & 0.49 \\
\hline Dy & 5.07 & 1.44 & 5.77 & 2.25 & 3.42 & 3.62 & 8.42 & 15.6 & 9.16 & 2.04 & 3.32 & 2.16 \\
\hline Но & 1.22 & 0.48 & 1.02 & 0.52 & 0.68 & 0.65 & 2.06 & 3.41 & 1.72 & 0.30 & 0.60 & 0.65 \\
\hline Er & 3.79 & 2.30 & 3.67 & 1.64 & 1.95 & 1.93 & 5.95 & 7.72 & 5.11 & 1.70 & 2.22 & 1.88 \\
\hline $\mathrm{Tm}$ & 0.49 & 0.28 & 0.54 & 0.36 & 0.32 & 0.86 & 0.49 & 1.50 & 0.77 & 0.31 & 0.21 & 0.67 \\
\hline $\mathbf{Y b}$ & 2.36 & 0.97 & 4.16 & 1.74 & 2.47 & 2.70 & 8.60 & 10.5 & 5.35 & 1.50 & 2.37 & 2.23 \\
\hline Lu & 0.50 & 0.35 & 0.60 & 0.43 & 0.41 & 0.67 & 1.06 & 1.75 & 0.78 & 0.22 & 0.14 & 0.34 \\
\hline Hf & 5.08 & 2.24 & 4.69 & 1.98 & 2.84 & 2.53 & 10.4 & 10.5 & 7.97 & 2.02 & 1.81 & 2.20 \\
\hline Ta & 0.59 & 0.62 & 0.63 & 0.34 & 0.78 & 0.65 & 2.59 & 4.85 & 0.69 & 0.34 & 0.98 & 0.93 \\
\hline W & 1.09 & 2.02 & 1.30 & 0.93 & 3.26 & 5.53 & 4.29 & 11.2 & 1.28 & 0.95 & 2.55 & 3.26 \\
\hline $\mathrm{Pb}$ & 25.7 & 2.86 & 22.7 & 2.99 & 15.8 & 5.56 & 67.0 & 23.6 & 30.7 & 3.91 & 22.6 & 5.09 \\
\hline Th & 10.7 & 2.63 & 10.5 & 2.18 & 18.7 & 6.26 & 63.2 & 19.9 & 10.9 & 1.38 & 18.1 & 4.32 \\
\hline $\mathbf{U}$ & 2.31 & 0.92 & 2.41 & 0.72 & 3.67 & 0.86 & 13.4 & 4.77 & 2.30 & 0.47 & 4.26 & 1.08 \\
\hline $\mathrm{Rb} / \mathrm{Sr}$ & 1.81 & 0.18 & 1.87 & 0.23 & 3.90 & 1.05 & 4.05 & 1.01 & 1.29 & 0.21 & 5.02 & 2.43 \\
\hline $\mathrm{Sr} / \mathrm{Y}$ & 1.92 & 0.30 & 1.84 & 0.32 & 1.97 & 0.98 & 1.97 & 0.89 & 1.57 & 0.13 & 1.34 & 1.23 \\
\hline $\mathrm{Zr} / \mathrm{Th}$ & 16.7 & 4.67 & 17.1 & 4.58 & 4.60 & 1.50 & 3.02 & 0.69 & 27.7 & 4.18 & 3.14 & 3.18 \\
\hline $\mathbf{E u} / \mathbf{E} u^{*}$ & 0.52 & 0.55 & 0.42 & 0.26 & 0.65 & 1.71 & 0.31 & 0.38 & 0.53 & 0.23 & 0.28 & 0.51 \\
\hline $\mathrm{Zr} / \mathrm{Y}$ & 5.56 & 0.82 & 5.73 & 2.12 & 4.06 & 1.68 & 4.83 & 1.74 & 6.12 & 0.34 & 2.36 & 1.87 \\
\hline $\mathrm{Ba} / \mathrm{Sr}$ & 12.3 & 1.11 & 12.3 & 1.74 & 20.6 & 5.06 & 36.0 & 9.00 & 7.32 & 0.52 & 25.7 & 9.67 \\
\hline $\mathrm{Nb} / \mathrm{Pb}$ & 0.28 & 0.06 & 0.31 & 0.09 & 0.50 & 0.18 & 0.18 & 0.09 & 0.36 & 0.08 & 0.37 & 0.12 \\
\hline $\mathrm{La} / \mathrm{Yb}$ & 9.98 & 5.11 & 5.33 & 2.81 & 12.6 & 16.7 & 9.12 & 15.9 & 5.77 & 1.81 & 13.8 & 36.5 \\
\hline $\mathrm{Dy} / \mathrm{Yb}$ & 2.21 & 1.04 & 1.44 & 0.74 & 2.26 & 5.64 & 1.45 & 4.21 & 1.74 & 0.58 & 1.61 & 2.63 \\
\hline $\mathrm{Ba} / \mathrm{Th}$ & 70.6 & 14.6 & 67.8 & 13.3 & 45.5 & 12.7 & 43.7 & 13.1 & 52.0 & 5.92 & 46.0 & 18.7 \\
\hline
\end{tabular}

Table A3: continued. 


\begin{tabular}{|c|c|c|c|c|c|c|c|c|c|c|c|c|}
\hline Sample number ${ }^{a}$ & \multicolumn{2}{|l|}{ M-53 } & \multicolumn{2}{|l|}{ M-54 } & \multicolumn{2}{|l|}{ M-55 } & \multicolumn{2}{|l|}{ M-56 } & \multicolumn{2}{|l|}{ M-57 } & \multicolumn{2}{|c|}{ M-58 (1) } \\
\hline Sample correlative $^{b}$ & & & & & & & AT-26 & & & & & \\
\hline Sample details ${ }^{c}$ & \multicolumn{2}{|c|}{$1124 \mathrm{C}-15 \mathrm{H}-3$} & \multicolumn{2}{|c|}{$1124 \mathrm{C}-15 \mathrm{H}-3$} & \multicolumn{2}{|c|}{$1124 \mathrm{C}-15 \mathrm{H}-4$} & \multicolumn{2}{|c|}{$1124 \mathrm{C}-15 \mathrm{H}-4$} & \multicolumn{2}{|c|}{$1124 \mathrm{C}-15 \mathrm{H}-5$} & \multicolumn{2}{|c|}{$1124 \mathrm{C}-15 \mathrm{H}-5$} \\
\hline Base $^{d}$ & \multicolumn{2}{|l|}{$41 \mathrm{~cm}$} & \multicolumn{2}{|c|}{$123 \mathrm{~cm}$} & $109 \mathrm{cn}$ & & $148 \mathrm{cn}$ & & $41 \mathrm{~cm}$ & & $71 \mathrm{~cm}$ & \\
\hline $\mathrm{mbsf}^{\mathrm{e}}$ & $144.61 \mathrm{~m}$ & & 145.43 & & 146.79 & & 147.18 & & 147.61 & & 147.91 & \\
\hline Age (Ma) & 7.058 & & 7.110 & & 7.166 & & 7.180 & & 7.210 & & 7.220 & \\
\hline$n^{f}$ & 10 & & 15 & & 9 & & 14 & & 8 & & 6 & \\
\hline LA-ICP-MS & Mean $^{\mathrm{g}}$ & $2 s d^{h}$ & & & & & & & & & & \\
\hline $\mathrm{Li}(\mathrm{ppm})^{\mathrm{i}}$ & 15.5 & 8.92 & 42.6 & 10.7 & 36.9 & 12.9 & 31.7 & 10.1 & 21.8 & 5.32 & 43.0 & 12.1 \\
\hline B & 12.5 & 15.3 & 21.8 & 13.1 & 20.8 & 13.4 & 11.3 & 20.0 & 40.3 & 12.5 & 20.4 & 4.86 \\
\hline $\mathrm{Mg}$ & 3770 & 3770 & 726 & 117 & 1870 & 1570 & 1440 & 290 & 3310 & 1850 & 565 & 89.1 \\
\hline $\mathrm{Si}$ & 73.0 & 4.13 & 76.1 & 1.27 & 73.3 & 1.26 & 74.6 & 0.77 & 74.2 & 3.15 & 75.5 & 0.41 \\
\hline $\mathrm{Ca}$ & 1.85 & 1.15 & 1.25 & 0.56 & 1.98 & 0.70 & 1.62 & 0.48 & 2.09 & 0.53 & 1.33 & 0.16 \\
\hline Sc & 10.6 & 7.29 & 12.6 & 4.21 & 15.6 & 5.55 & 14.5 & 5.97 & 9.74 & 5.71 & 17.0 & 3.43 \\
\hline $\mathrm{Ti}$ & 2520 & 1750 & 1490 & 141 & 2900 & 1330 & 2680 & 181 & 3840 & 1540 & 1012 & 129 \\
\hline $\mathbf{V}$ & 17.3 & 29.6 & 0.34 & 1.37 & 7.07 & 40.7 & 0.50 & 4.72 & 25.9 & 19.1 & 0.11 & 0.37 \\
\hline $\mathrm{Cr}$ & 2.86 & 30.2 & 2.63 & 58.3 & bd & & bd & & bd & & 2.24 & 11.3 \\
\hline Mn & 842 & 510 & 979 & 109 & 1260 & 180 & 1420 & 89.2 & 1190 & 241 & 521 & 58.0 \\
\hline $\mathrm{Ni}$ & bd & & bd & & bd & & bd & & bd & & 0.20 & 4.16 \\
\hline $\mathrm{Cu}$ & 15.9 & 31.2 & bd & & 38.0 & 74.9 & 2.72 & 226 & 61.5 & 71.9 & 3.57 & 2.70 \\
\hline $\mathrm{Zn}$ & 79.1 & 56.2 & 116 & 32.1 & 92.6 & 70.6 & 137 & 60.8 & 82.1 & 29.2 & 65.6 & 17.9 \\
\hline $\mathbf{R b}$ & 67.9 & 37.6 & 93.3 & 11.6 & 89.1 & 7.89 & 143 & 15.9 & 65.8 & 10.7 & 115 & 9.39 \\
\hline $\mathrm{Sr}$ & 218 & 155 & 84.9 & 11.4 & 124 & 20.0 & 180 & 17.3 & 137 & 47.4 & 89.1 & 15.4 \\
\hline Y & 36.5 & 14.5 & 38.0 & 5.87 & 42.6 & 7.55 & 67.9 & 8.96 & 34.1 & 12.2 & 42.7 & 5.25 \\
\hline $\mathrm{Zr}$ & 219 & 53.1 & 201 & 23.9 & 237 & 55.3 & 353 & 47.6 & 183 & 28.2 & 274 & 29.0 \\
\hline Nb & 5.42 & 5.69 & 9.46 & 1.73 & 9.90 & 1.48 & 15.7 & 4.87 & 6.05 & 2.57 & 11.1 & 1.24 \\
\hline Cs & 2.39 & 3.34 & 5.37 & 1.24 & 5.02 & 1.38 & 11.7 & 3.24 & 2.56 & 0.44 & 6.14 & 0.85 \\
\hline $\mathrm{Ba}$ & 933 & 384 & 763 & 64.4 & 779 & 97.8 & 1557 & 177 & 1338 & 148 & 780 & 32.9 \\
\hline La & 22.2 & 8.34 & 20.3 & 3.47 & 22.5 & 4.72 & 45.3 & 5.91 & 16.0 & 4.64 & 30.0 & 1.63 \\
\hline $\mathrm{Ce}$ & 47.7 & 22.9 & 56.0 & 4.96 & 55.3 & 7.41 & 112 & 6.82 & 42.7 & 8.85 & 68.2 & 5.39 \\
\hline $\operatorname{Pr}$ & 5.95 & 2.12 & 4.77 & 1.91 & 5.95 & 0.91 & 11.7 & 2.04 & 4.58 & 1.35 & 7.49 & 0.99 \\
\hline Nd & 27.3 & 12.8 & 21.8 & 5.26 & 23.6 & 6.57 & 50.5 & 9.48 & 20.5 & 8.95 & 31.6 & 3.53 \\
\hline $\mathrm{Sm}$ & 5.31 & 3.41 & 5.79 & 4.41 & 5.65 & 4.76 & 11.9 & 6.07 & 4.44 & 4.32 & 7.97 & 2.08 \\
\hline Eu & 0.94 & 1.07 & 1.08 & 0.88 & 1.24 & 1.02 & 2.21 & 2.24 & 1.34 & 1.41 & 0.92 & 0.26 \\
\hline Gd & 4.73 & 2.63 & 4.91 & 2.93 & 6.08 & 5.21 & 12.3 & 8.93 & 5.85 & 4.47 & 7.22 & 2.33 \\
\hline Tb & 0.84 & 0.56 & 0.78 & 0.64 & 0.77 & 0.75 & 1.92 & 1.11 & 0.94 & 1.09 & 1.11 & 0.11 \\
\hline Dy & 6.46 & 3.46 & 6.45 & 1.93 & 7.31 & 3.21 & 17.7 & 7.21 & 6.70 & 5.18 & 8.02 & 2.33 \\
\hline Но & 1.19 & 0.75 & 1.26 & 0.99 & 1.33 & 0.72 & 3.26 & 1.92 & 1.39 & 0.67 & 1.58 & 0.29 \\
\hline Er & 3.79 & 2.47 & 4.97 & 2.94 & 4.72 & 2.37 & 11.5 & 4.97 & 5.25 & 3.00 & 4.70 & 0.98 \\
\hline $\mathrm{Tm}$ & 0.59 & 0.35 & 0.51 & 0.65 & 0.45 & 0.63 & 1.27 & 1.18 & 0.65 & 0.27 & 0.62 & 0.13 \\
\hline Yb & 4.18 & 2.18 & 4.93 & 2.79 & 5.09 & 3.36 & 11.9 & 5.61 & 4.54 & 3.21 & 4.37 & 0.72 \\
\hline Lu & 0.65 & 0.32 & 0.58 & 0.48 & 0.69 & 0.76 & 1.24 & 1.16 & 0.65 & 0.80 & 0.64 & 0.24 \\
\hline Hf & 5.19 & 2.11 & 5.77 & 2.41 & 5.90 & 2.33 & 14.1 & 8.34 & 6.33 & 1.63 & 5.87 & 2.13 \\
\hline Ta & 0.32 & 0.65 & 1.22 & 0.87 & 0.79 & 1.41 & 1.62 & 1.55 & 0.41 & 0.87 & 0.77 & 0.16 \\
\hline W & 0.61 & 1.48 & 0.71 & 2.81 & 0.90 & 3.49 & 4.48 & 6.39 & 0.41 & 1.83 & 1.26 & 0.84 \\
\hline $\mathrm{Pb}$ & 13.7 & 5.65 & 24.8 & 4.57 & 23.9 & 6.16 & 52.5 & 14.9 & 14.3 & 2.10 & 23.8 & 3.98 \\
\hline Th & 9.41 & 3.20 & 10.5 & 2.44 & 10.4 & 1.84 & 25.4 & 6.27 & 9.54 & 2.38 & 11.5 & 1.74 \\
\hline $\mathbf{U}$ & 1.93 & 0.50 & 2.69 & 0.95 & 2.20 & 0.74 & 5.60 & 2.20 & 2.74 & 0.93 & 2.62 & 0.68 \\
\hline $\mathrm{Rb} / \mathrm{Sr}$ & 0.35 & 0.45 & 1.10 & 0.20 & 0.72 & 0.15 & 0.80 & 0.14 & 0.50 & 0.22 & 1.30 & 0.19 \\
\hline $\mathrm{Sr} / \mathrm{Y}$ & 6.33 & 4.850 & 2.25 & 0.39 & 2.92 & 0.34 & 2.66 & 0.46 & 4.03 & 0.63 & 2.09 & 0.33 \\
\hline $\mathrm{Zr} / \mathrm{Th}$ & 23.7 & 6.53 & 19.3 & 3.64 & 22.8 & 4.72 & 14.1 & 3.22 & 19.4 & 5.00 & 23.8 & 1.87 \\
\hline $\mathrm{Eu} / \mathbf{E} \mathbf{u}^{*}$ & 0.58 & 0.54 & 0.68 & 0.63 & 0.72 & 0.59 & 0.61 & 0.76 & 0.92 & 0.84 & 0.38 & 0.16 \\
\hline $\mathrm{Zr} / \mathrm{Y}$ & 6.29 & 3.69 & 5.33 & 0.80 & 5.56 & 0.78 & 5.21 & 0.72 & 5.57 & 2.78 & 6.43 & 0.68 \\
\hline $\mathrm{Ba} / \mathrm{Sr}$ & 5.04 & 5.10 & 9.03 & 1.67 & 6.31 & 1.36 & 8.67 & 1.42 & 10.1 & 4.13 & 8.81 & 1.49 \\
\hline $\mathrm{Nb} / \mathrm{Pb}$ & 0.39 & 0.28 & 0.38 & 0.06 & 0.42 & 0.11 & 0.30 & 0.11 & 0.42 & 0.13 & 0.47 & 0.10 \\
\hline $\mathrm{La} / \mathrm{Yb}$ & 5.62 & 3.18 & 4.45 & 2.76 & 4.99 & 3.88 & 4.04 & 2.35 & 3.92 & 3.07 & 6.90 & 1.17 \\
\hline Dy/Yb & 1.58 & 0.67 & 1.42 & 0.88 & 1.60 & 2.03 & 1.59 & 1.11 & 1.50 & 1.04 & 1.83 & 0.45 \\
\hline $\mathrm{Ba} / \mathrm{Th}$ & 103 & 57.3 & 73.3 & 13.8 & 75.1 & 12.2 & 62.2 & 15.4 & 142 & 30.8 & 68.0 & 10.9 \\
\hline
\end{tabular}

Table A3: continued. 


\begin{tabular}{|c|c|c|c|c|c|c|c|c|c|c|c|c|}
\hline Sample number ${ }^{a}$ & \multicolumn{2}{|c|}{ M-58 (2) } & \multicolumn{2}{|l|}{ M-59 } & \multicolumn{2}{|l|}{ M-60 } & \multicolumn{2}{|c|}{ M-61 (1) } & \multicolumn{2}{|c|}{ M-61 (2) } & \multicolumn{2}{|l|}{ M-62 } \\
\hline \multicolumn{13}{|c|}{ Sample correlative $^{\mathrm{b}}$} \\
\hline Sample details ${ }^{c}$ & \multicolumn{2}{|c|}{$1124 \mathrm{C}-15 \mathrm{H}-5$} & \multicolumn{2}{|c|}{$1124 \mathrm{C}-15 \mathrm{H}-6$} & \multicolumn{2}{|c|}{$1124 \mathrm{C}-16 \mathrm{H}-2$} & \multicolumn{2}{|c|}{$1124 \mathrm{C}-16 \mathrm{H}-2$} & \multicolumn{2}{|c|}{$1124 \mathrm{C}-16 \mathrm{H}-2$} & \multicolumn{2}{|c|}{$1124 \mathrm{C}-16 \mathrm{H}-2$} \\
\hline Base $^{d}$ & \multicolumn{2}{|l|}{$71 \mathrm{~cm}$} & $38 \mathrm{~cm}$ & & $20 \mathrm{~cm}$ & & $64 \mathrm{~cm}$ & & $64 \mathrm{~cm}$ & & $118 \mathrm{cn}$ & \\
\hline $\operatorname{mbsf}^{e}$ & $147.91 n$ & & 149.08 & & 152.40 & & 152.84 & & 152.84 & & 153.38 & \\
\hline Age (Ma) & 7.220 & & 7.280 & & 7.550 & & 7.580 & & 7.580 & & 7.590 & \\
\hline$n^{f}$ & 4 & & 11 & & 16 & & 10 & & 6 & & 10 & \\
\hline LA-ICP-MS & Mean $^{g}$ & $2 s d^{h}$ & & & & & & & & & & \\
\hline $\mathrm{Li}(\mathrm{ppm})^{\mathrm{i}}$ & 37.4 & 19.2 & 40.2 & 33.3 & 25.0 & 7.82 & 19.5 & 6.33 & 50.1 & 9.11 & 45.9 & 25.4 \\
\hline B & 47.0 & 2.67 & 38.9 & 8.60 & 7.40 & 2.39 & 6.56 & 5.54 & 32.3 & 5.55 & 27.7 & 10.8 \\
\hline Mg & 1080 & 90.2 & 204 & 30.6 & 1870 & 383 & 2144 & 711 & 353 & 160 & 985 & 1140 \\
\hline $\mathrm{Si}$ & 76.9 & 0.17 & 77.1 & 0.69 & 76.2 & 0.85 & 75.3 & 0.47 & 76.3 & 0.64 & 77.4 & 1.26 \\
\hline $\mathrm{Ca}$ & 1.18 & 0.18 & 0.60 & 0.37 & 1.11 & 0.13 & 1.31 & 0.41 & 0.96 & 0.08 & 1.38 & 0.67 \\
\hline Sc & 12.2 & 2.02 & 7.46 & 7.09 & 12.7 & 1.52 & 13.6 & 2.37 & 14.4 & 6.37 & 10.2 & 5.84 \\
\hline $\mathrm{Ti}$ & 1095 & 46.4 & 215 & 38.9 & 2070 & 68.0 & 2567 & 195 & 916 & 192 & 966 & 807 \\
\hline V & 1.44 & 0.78 & 0.21 & 2.77 & 1.48 & 0.84 & 1.28 & 2.59 & 0.79 & 0.85 & 1.34 & 4.23 \\
\hline $\mathrm{Cr}$ & bd & & 1.49 & 18.0 & 0.25 & 2.61 & 13.1 & 54.3 & bd & & bd & \\
\hline Mn & 371 & 18.0 & 320 & 38.9 & 1020 & 94.1 & 1136 & 82.2 & 308 & 18.9 & 493 & 240 \\
\hline $\mathrm{Ni}$ & 1.66 & 3.39 & 0.40 & 10.6 & 0.26 & 1.13 & bd & & bd & & bd & \\
\hline $\mathrm{Cu}$ & 6.45 & 5.49 & 1.97 & 10.2 & 2.83 & 11.0 & 7.58 & 31.0 & 1.77 & 4.56 & 0.99 & 12.8 \\
\hline Zn & 31.1 & 11.9 & 29.8 & 14.9 & 79.1 & 37.7 & 92.8 & 23.6 & 63.1 & 15.3 & 67.3 & 35.3 \\
\hline $\mathbf{R b}$ & 131 & 5.37 & 154 & 13.8 & 75.5 & 4.63 & 64.2 & 9.18 & 118 & 12.3 & 112 & 26.2 \\
\hline $\mathrm{Sr}$ & 72.7 & 5.74 & 27.5 & 3.36 & 92.1 & 11.1 & 110 & 11.9 & 67.8 & 13.3 & 106 & 25.2 \\
\hline Y & 28.2 & 7.56 & 26.3 & 5.88 & 52.7 & 9.79 & 43.9 & 4.80 & 32.4 & 3.58 & 28.8 & 6.59 \\
\hline $\mathrm{Zr}$ & 188 & 33.2 & 67.7 & 12.0 & 275 & 42.2 & 250 & 27.3 & 138 & 13.7 & 179 & 72.5 \\
\hline $\mathrm{Nb}$ & 8.55 & 1.02 & 6.64 & 3.14 & 10.9 & 0.97 & 10.0 & 1.98 & 9.57 & 1.03 & 8.10 & 2.96 \\
\hline Cs & 7.16 & 0.52 & 7.50 & 2.14 & 2.85 & 0.34 & 2.25 & 0.32 & 6.77 & 0.75 & 5.19 & 1.60 \\
\hline $\mathrm{Ba}$ & 873 & 76.1 & 686 & 86.8 & 598 & 54.9 & 571 & 37.5 & 746 & 43.8 & 1313 & 475 \\
\hline La & 24.5 & 3.48 & 13.5 & 3.54 & 27.0 & 4.35 & 23.1 & 3.44 & 32.4 & 4.95 & 39.7 & 18.3 \\
\hline $\mathrm{Ce}$ & 49.4 & 3.68 & 34.0 & 6.17 & 61.3 & 4.33 & 52.7 & 10.7 & 70.2 & 11.6 & 91.5 & 38.5 \\
\hline Pr & 5.21 & 0.48 & 3.41 & 1.20 & 7.68 & 1.27 & 6.36 & 0.42 & 7.94 & 1.23 & 9.32 & 4.39 \\
\hline Nd & 21.0 & 2.54 & 12.3 & 6.19 & 35.4 & 5.36 & 28.1 & 4.77 & 28.7 & 4.99 & 31.2 & 13.0 \\
\hline $\mathrm{Sm}$ & 5.03 & 1.55 & 2.87 & 6.34 & 7.49 & 1.25 & 7.04 & 3.26 & 6.22 & 2.73 & 5.54 & 5.67 \\
\hline Eu & 0.63 & 0.18 & 0.47 & 2.36 & 2.00 & 0.35 & 1.76 & 0.32 & 0.69 & 0.34 & 0.70 & 0.97 \\
\hline Gd & 3.78 & 0.87 & 1.20 & 7.87 & 8.09 & 2.12 & 7.20 & 1.96 & 5.23 & 2.40 & 4.05 & 3.75 \\
\hline Tb & 0.71 & 0.33 & 0.28 & 0.69 & 1.30 & 0.32 & 1.14 & 0.31 & 0.85 & 0.49 & 0.92 & 0.58 \\
\hline Dy & 5.24 & 1.85 & 2.12 & 3.85 & 9.87 & 2.17 & 7.98 & 1.61 & 6.44 & 2.14 & 4.34 & 4.39 \\
\hline Но & 1.05 & 0.54 & 0.46 & 1.27 & 1.86 & 0.40 & 1.62 & 0.28 & 1.27 & 0.36 & 1.22 & 0.93 \\
\hline Er & 3.13 & 1.06 & 2.21 & 3.21 & 5.84 & 1.28 & 4.94 & 1.81 & 3.54 & 0.95 & 3.00 & 2.89 \\
\hline $\mathrm{Tm}$ & 0.45 & 0.05 & 0.17 & 0.87 & 0.88 & 0.21 & 0.73 & 0.13 & 0.53 & 0.26 & 0.48 & 1.05 \\
\hline $\mathbf{Y b}$ & 3.28 & 0.73 & 2.05 & 5.07 & 6.20 & 1.08 & 5.03 & 2.23 & 3.35 & 1.01 & 2.99 & 2.75 \\
\hline Lu & 0.43 & 0.16 & 0.19 & 0.89 & 0.92 & 0.26 & 0.82 & 0.37 & 0.53 & 0.38 & 0.35 & 0.44 \\
\hline Hf & 5.18 & 0.57 & 2.31 & 4.21 & 7.45 & 1.58 & 6.00 & 1.37 & 4.78 & 1.08 & 6.09 & 4.75 \\
\hline Ta & 0.78 & 0.21 & 0.66 & 1.08 & 0.87 & 0.21 & 0.60 & 0.31 & 0.70 & 0.54 & 0.64 & 0.92 \\
\hline W & 1.73 & 0.59 & 2.86 & 6.57 & 0.76 & 0.66 & 0.64 & 0.54 & 1.43 & 0.66 & 1.44 & 2.88 \\
\hline $\mathrm{Pb}$ & 18.3 & 1.75 & 17.9 & 2.92 & 16.9 & 1.66 & 13.0 & 2.38 & 24.8 & 3.56 & 23.7 & 9.36 \\
\hline Th & 14.1 & 2.50 & 10.7 & 3.41 & 9.44 & 1.91 & 7.56 & 0.78 & 12.8 & 0.76 & 13.0 & 3.06 \\
\hline $\mathbf{U}$ & 2.98 & 0.48 & 2.94 & 1.76 & 2.31 & 0.22 & 1.77 & 0.48 & 2.84 & 0.67 & 3.00 & 1.30 \\
\hline $\mathrm{Rb} / \mathrm{Sr}$ & 1.80 & 0.11 & 5.62 & 0.89 & 0.82 & 0.12 & 0.59 & 0.11 & 1.76 & 0.41 & 1.07 & 0.35 \\
\hline $\mathrm{Sr} / \mathrm{Y}$ & 2.60 & 0.45 & 1.06 & 0.27 & 1.75 & 0.12 & 2.50 & 0.31 & 2.10 & 0.52 & 3.72 & 1.35 \\
\hline $\mathrm{Zr} / \mathrm{Th}$ & 13.3 & 1.18 & 6.45 & 1.91 & 29.2 & 3.01 & 33.1 & 3.84 & 10.7 & 0.93 & 13.9 & 7.18 \\
\hline $\mathbf{E u} / \mathbf{E} u^{*}$ & 0.44 & 0.16 & 1.34 & 4.00 & 0.79 & 0.17 & 0.77 & 0.18 & 0.38 & 0.24 & 0.62 & 0.87 \\
\hline $\mathrm{Zr} / \mathrm{Y}$ & 6.69 & 0.77 & 2.59 & 0.58 & 5.22 & 0.27 & 5.69 & 0.54 & 4.26 & 0.47 & 6.20 & 2.03 \\
\hline $\mathrm{Ba} / \mathrm{Sr}$ & 12.0 & 0.10 & 25.0 & 3.66 & 6.50 & 0.45 & 5.22 & 0.57 & 11.1 & 1.88 & 12.4 & 4.22 \\
\hline $\mathrm{Nb} / \mathrm{Pb}$ & 0.47 & 0.10 & 0.37 & 0.15 & 0.65 & 0.06 & 0.78 & 0.22 & 0.39 & 0.04 & 0.35 & 0.20 \\
\hline $\mathrm{La} / \mathrm{Yb}$ & 7.57 & 2.63 & 13.1 & 36.9 & 4.36 & 0.63 & 4.75 & 1.79 & 9.93 & 4.53 & 17.2 & 21.5 \\
\hline Dy/Yb & 1.62 & 0.67 & 2.43 & 8.37 & 1.59 & 0.29 & 1.66 & 0.88 & 1.93 & 0.54 & 1.75 & 2.81 \\
\hline $\mathrm{Ba} / \mathrm{Th}$ & 62.0 & 8.00 & 65.5 & 20.1 & 63.8 & 8.78 & 75.8 & 9.78 & 58.1 & 1.43 & 101 & 34.3 \\
\hline
\end{tabular}

Table A3: continued. 


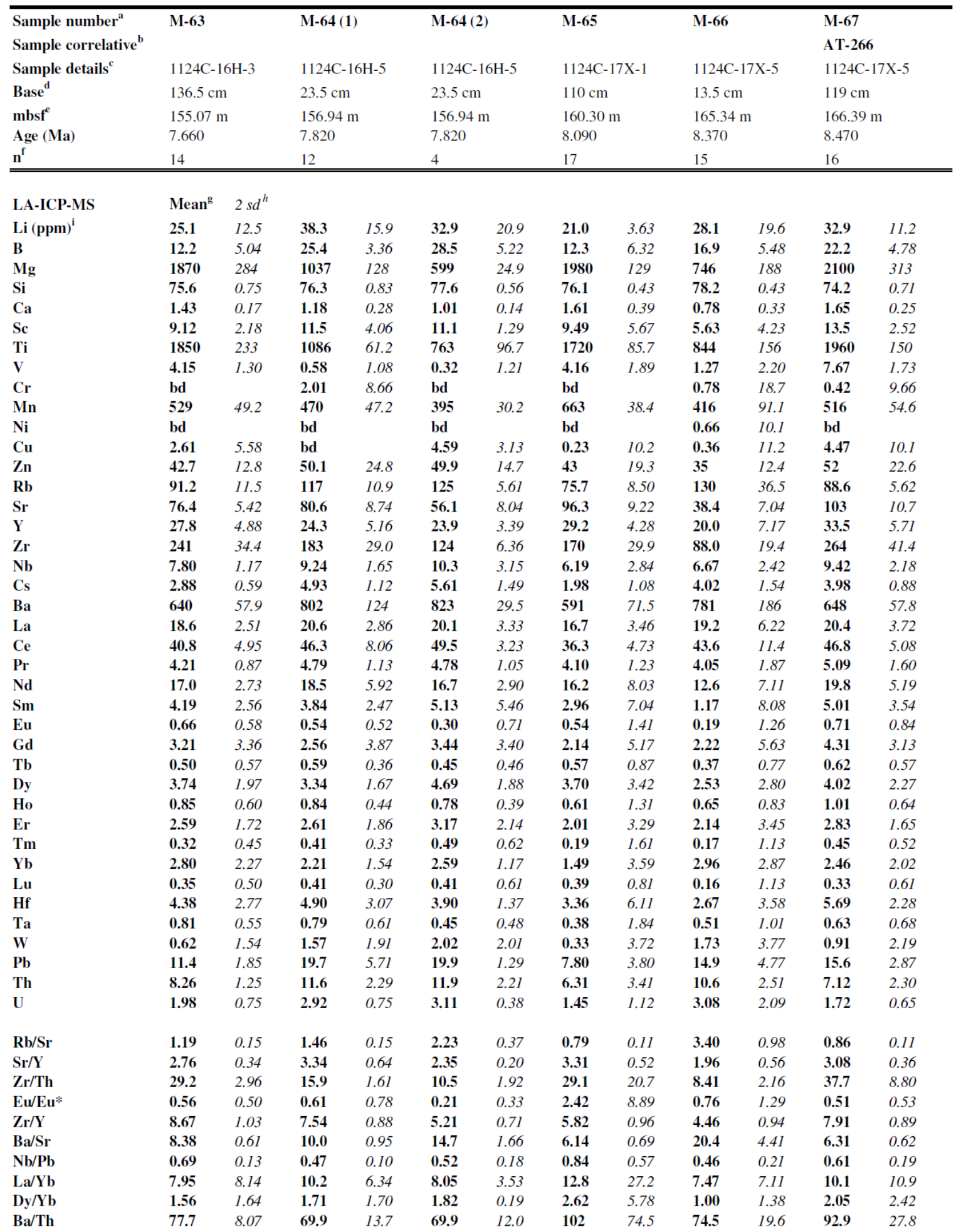

Table A3: continued. 


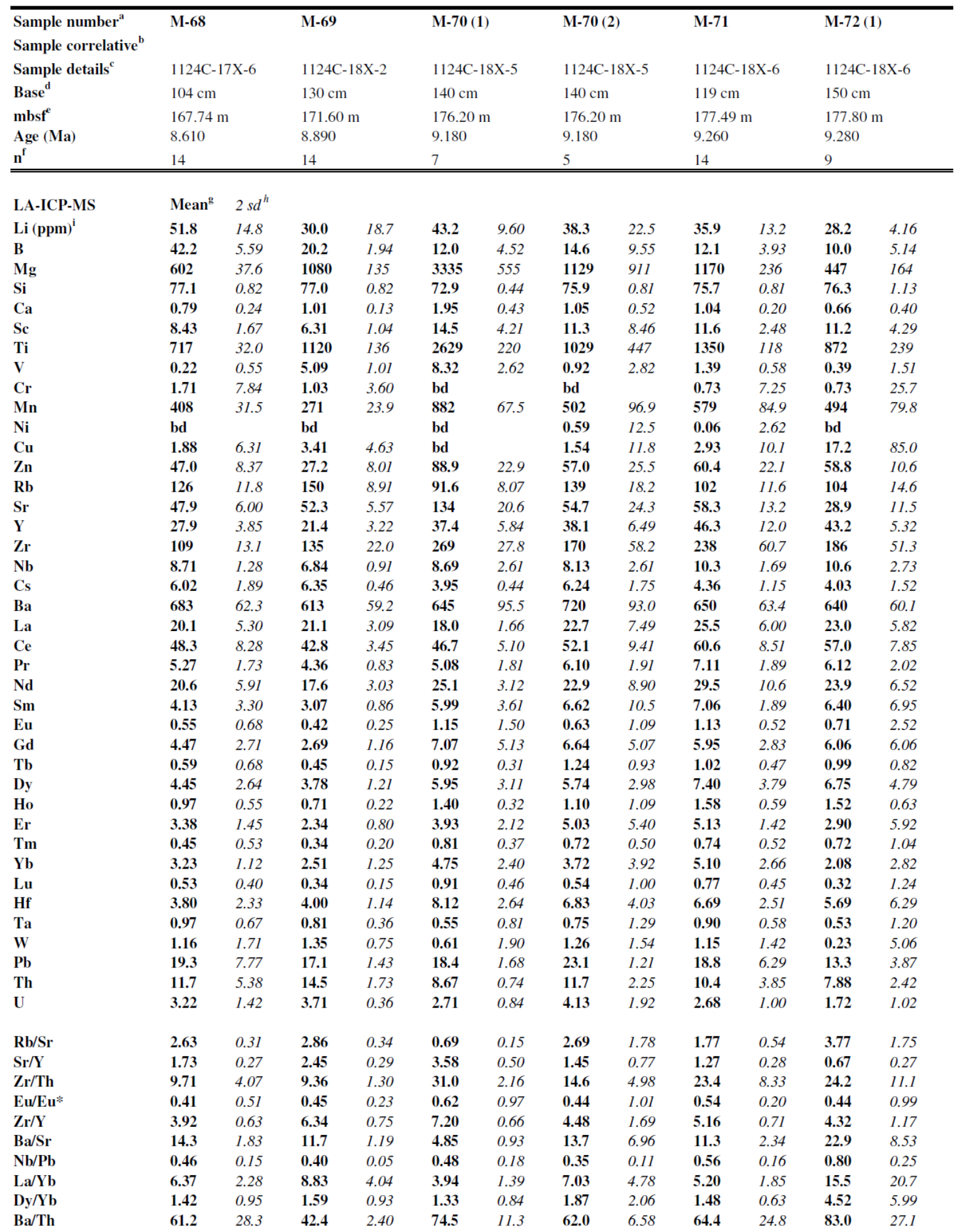

Table A3: continued. 


\begin{tabular}{|c|c|c|}
\hline Sample number ${ }^{\mathrm{a}}$ & \multicolumn{2}{|c|}{ M-72 (2) } \\
\hline \multicolumn{3}{|l|}{ Sample correlative ${ }^{\text {b }}$} \\
\hline Sample details ${ }^{\mathrm{c}}$ & \multicolumn{2}{|c|}{$1124 C-18 X-6$} \\
\hline Base $^{d}$ & \multicolumn{2}{|l|}{$150 \mathrm{~cm}$} \\
\hline $\mathrm{mbsf}^{e}$ & \multicolumn{2}{|c|}{$177.80 \mathrm{~m}$} \\
\hline Age (Ma) & \multicolumn{2}{|c|}{9.280} \\
\hline$n^{f}$ & \multicolumn{2}{|l|}{6} \\
\hline LA-ICP-MS & Mean $^{\mathrm{g}}$ & $2 s d^{h}$ \\
\hline $\mathbf{L i}(\mathbf{p p m})^{\mathrm{i}}$ & 28.2 & 7.53 \\
\hline B & 8.30 & 7.15 \\
\hline $\mathrm{Mg}$ & 972 & 87.3 \\
\hline $\mathrm{Si}$ & 74.9 & 1.11 \\
\hline $\mathrm{Ca}$ & 1.11 & 0.73 \\
\hline Sc & 11.0 & 2.12 \\
\hline $\mathrm{Ti}$ & 1354 & 60.4 \\
\hline V & bd & \\
\hline $\mathrm{Cr}$ & bd & \\
\hline Mn & 642 & 35.5 \\
\hline $\mathrm{Ni}$ & 3.09 & 8.95 \\
\hline $\mathrm{Cu}$ & 5.79 & 14.8 \\
\hline $\mathrm{Zn}$ & 64.6 & 20.8 \\
\hline $\mathbf{R b}$ & 90.4 & 6.99 \\
\hline $\mathrm{Sr}$ & 52.0 & 5.72 \\
\hline $\mathrm{Y}$ & 42.6 & 9.97 \\
\hline $\mathrm{Zr}$ & 266 & 28.8 \\
\hline $\mathrm{Nb}$ & 10.5 & 2.44 \\
\hline Cs & 3.55 & 1.15 \\
\hline $\mathrm{Ba}$ & 629 & 28.3 \\
\hline La & 22.9 & 5.84 \\
\hline $\mathrm{Ce}$ & 52.2 & 11.0 \\
\hline Pr & 6.30 & 2.63 \\
\hline Nd & 23.4 & 13.3 \\
\hline $\mathrm{Sm}$ & 4.72 & 5.66 \\
\hline Eu & 1.09 & 0.96 \\
\hline Gd & 5.30 & 4.34 \\
\hline Tb & 0.55 & 1.02 \\
\hline Dy & 6.29 & 5.16 \\
\hline Ho & 1.07 & 0.41 \\
\hline $\mathrm{Er}$ & 4.55 & 2.25 \\
\hline $\mathrm{Tm}$ & 0.45 & 0.58 \\
\hline $\mathbf{Y b}$ & 2.26 & 1.32 \\
\hline Lu & 0.57 & 1.07 \\
\hline Hf & 5.76 & 2.99 \\
\hline Ta & 0.38 & 2.10 \\
\hline W & 0.45 & 4.84 \\
\hline $\mathrm{Pb}$ & 10.9 & 1.59 \\
\hline Th & 6.60 & 1.85 \\
\hline $\mathbf{U}$ & 1.45 & 1.30 \\
\hline $\mathrm{Rb} / \mathrm{Sr}$ & 1.74 & 0.24 \\
\hline $\mathrm{Sr} / \mathrm{Y}$ & 1.23 & 0.20 \\
\hline $\mathrm{Zr} / \mathrm{Th}$ & 40.8 & 8.35 \\
\hline $\mathbf{E u} / \mathbf{E} u^{*}$ & 0.72 & 0.51 \\
\hline $\mathrm{Zr} / \mathrm{Y}$ & 6.28 & 0.91 \\
\hline $\mathrm{Ba} / \mathrm{Sr}$ & 12.1 & 1.07 \\
\hline $\mathrm{Nb} / \mathrm{Pb}$ & 0.97 & 0.21 \\
\hline $\mathrm{La} / \mathrm{Yb}$ & 11.3 & 9.51 \\
\hline $\mathrm{Dy} / \mathrm{Yb}$ & 3.18 & 3.32 \\
\hline $\mathrm{Ba} / \mathrm{Th}$ & 96.9 & 28.9 \\
\hline
\end{tabular}

Table A3: continued. ${ }^{\text {a }}$ Samples with multiple glass populations are presented separately e.g. M-2 (1) and M-2 (2). ' Samples prefixed "AT-" were previously assigned by Carter et al. (2004). ${ }^{\mathrm{c}}$ Core details - e.g. $1124 \mathrm{C}-7 \mathrm{H}-3=$ Site 1124 , hole $\mathrm{C}$, core 7 , core type $(\mathrm{H}=$ hydraulic piston), section 3 . ${ }^{\mathrm{d}}$ Depth to base of ash $(\mathrm{cm})$ in relevant core section. ${ }^{\mathrm{e}}$ Depth to base of tephra in metres below sea floor in the corresponding hole. ${ }^{\mathrm{f}}$ Number of analyses. ${ }^{\mathrm{g}}$ Mean of $\mathrm{n}$ analyses. ${ }^{\mathrm{h}} \pm 2$ standard deviations. ${ }^{\mathrm{i}}$ Mean composition in $\mathrm{ppm}$. 


\section{Appendix Four}

\section{CD - Raw and Processed Data}

